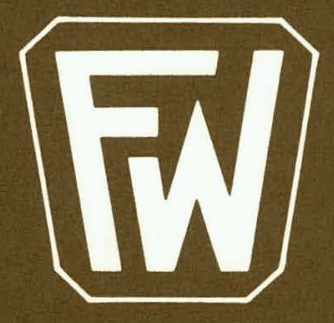

FOSTER WHEELER DEVELOPMENT CORPORATION 


\section{DISCLAIMER}

This report was prepared as an account of work sponsored by an agency of the United States Government. Neither the United States Government nor any agency Thereof, nor any of their employees, makes any warranty, express or implied, or assumes any legal liability or responsibility for the accuracy, completeness, or usefulness of any information, apparatus, product, or process disclosed, or represents that its use would not infringe privately owned rights. Reference herein to any specific commercial product, process, or service by trade name, trademark, manufacturer, or otherwise does not necessarily constitute or imply its endorsement, recommendation, or favoring by the United States Government or any agency thereof. The views and opinions of authors expressed herein do not necessarily state or reflect those of the United States Government or any agency thereof. 


\section{DISCLAIMER}

Portions of this document may be illegible in electronic image products. Images are produced from the best available original document. 


\section{VOLUME 3--APPENDICES (CONT) \\ FinAL REPORT \\ FOR

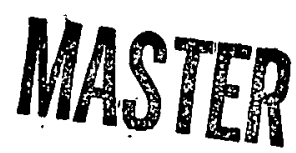 \\ Solar Production of Industrial Process Steam \\ Ranging in Temperature From $360^{\circ} \mathrm{F}$ to $550^{\circ} \mathrm{F}$ \\ (PHASE I)}

PERIOD OF PERFORMANCE
SEPTEMBER 30,1978 TO JUNE 30,1979

DOE CONTRACT NO. ET-78-C-03-2199

FWDC NO. 9-41-4010

JUNE 30,1979

\section{FOSTER WHEELER DEVELOPMENT CORPORATION}

12 Peach Tree Hill Road. Livingston. New Jersey 07039

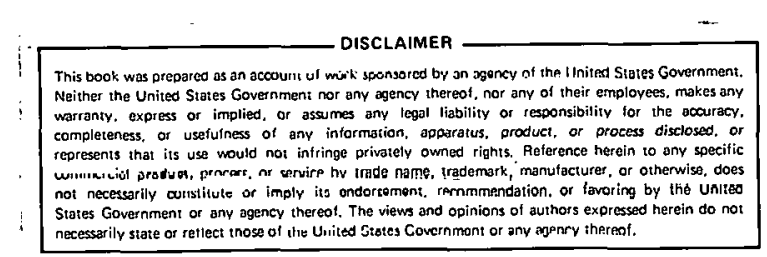


APPENDIX $D .7$

INSTRUMENTS 
FOSTER WHEELER
PROCESS PLANTS DIYISION

PAGE

1

2

3

4

5

6

7

8

9

10

* 11

12

13

14

15

16

17

18

19

20

21

22

23

24

* 25

26

27

- 28

29

30

31

32

32

33

34

35

36

37

$\begin{array}{r}-38 \\ \hline\end{array}$

39

40
INSTRUMENTATION

JOB SPECIFICATION 60863-60AI

REVISION INDEX

REV

0

0

0

0

0

0

0

0

0

1

0

0
0

0

0

0

0

0

0

0

0

0

1

0

0

1
0

0

0

0

0

0

0

0

0

0

0

0
ENG. STD. 60A 1 INOEX PAGE 1 ISSUE 1

DATE SeP 1, 1978

DATE

$5 / 1 / 78$

$5 / 1 / 78$

$5 / 1 / 78$

$5 / 1 / 78$

$5 / 1 / 78$

$5 / 1 / 78$

$5 / 1 / 78$

$5 / 1 / 78$

$5 / 1 / 78$

$5 / 1 / 78$

$9 / 1 / 78$

$5 / 1 / 78$

$5 / 1 / 78$

$5 / 1 / 78$

$5 / 1 / 78$

$5 / 1 / 78$

$5 / 1 / 78$

$5 / 1 / 78$

$5 / 1 / 78$

$5 / 1 / 78$

$5 / 1 / 78$

$5 / 1 / 78$

$5 / 1 / 78$

$5 / 1 / 78$

$9 / 1 / 78$

$5 / 1 / 78$

$5 / 1 / 78$

$9 / 1 / 78$

$5 / 1 / 78$

$5 / 1 / 78$

$5 / 1 / 78$

$5 / 1 / 78$

$5 / 1 / 78$

$5 / 1 / 78$

$5 / 1 / 78$

$5 / 1 / 78$

$5 / 1 / 78$

$5 / 1 / 78$

$9 / 1 / 78$

$5 / 1 / 78$

$5 / 1 / 78$

- PAGES REVISED for this ISSUE ARE NOTED by ASTERISK.

REASON FOR REVISION:

Standard Updated 
FOSTER WHEELER
PROCESS PLANTS DIVISION

JOB

\section{INSTRUMENTATION}

SPECIFICATION 60863-60A1

REVISION INDEX

PAGE

41

42

43

$* 44$

* 45

46
REV.

0

0

0

1

1

0
ENG. STD. $60 \mathrm{~A} 1$ INDEX PAGE 2 ISSUE 1

DATE Sep 1, 1978

DATE

$5 / 1 / 78$

$5 / 1 / 78$

$5 / 1 / 78$

$9 / 1 / 78$

$9 / 1 / 78$

$5 / 1 / 78$ 


\section{FOSTER FHEELER \\ PROCESS PLANTS DIVISION}

INSTRUMENTATION

ENG STO

PAGE

REVISION 0

DATE May 1, 1978

\section{CONTENTS}

\section{PAGE}

I. SCOPE 2 . 2

II. GENERAL 2

A. Instrument Terminology 2

B. Flow Diagram Symbols and Instrument Identifications 2

C. Instrument Index 2

D. Package Units . 2

III. DESIGN REQUIREMENTS . . . 2

A. General _. 2

1. Tagging 2

2. Painting ' 3

3. Electrical Equipment and Enclosures 3

4. Transmitters 3

5. Transmission Systems 3

B. Temperature Instruments 4

C. Flow Instruments 6

D. Liquid Level Instruments 10

E. Pressure Instruments (Including Non-Flow Differential Pressure) 12

F. Automatic Controllers 14

G. Recorders, Chart Drives, Scales, and Charts 15

H. Transmission Systems 1 ?

J. Alarms and Signals 21

K. Emergency Systems 22

L. Control Valves 23

M. Pressura Relieving Devices ' 29

N. Control Panels $\quad 30$

$P$. Analyzers $\quad 31$

Q. Connections for Instruments on Vessels and Piping 33

R. Instrument Air Supply 35

S. Accessibility 36

T. Winterization . 38

U. Inspection . 38

V. Field Testing and Calibration 38

$\begin{array}{ll}\text { W. Panel Types } & 38\end{array}$

IV. REFERENCES 44 
ENG STD 60A 1

PAGE 2

REVISION 0

INSTRUMENTATION

FOSTER

WHEELER

DATE May 1, 1978

PROCESS PLANTS DIYISION

I. SCOPE

Instruments and controls are to be furnished in accordance with this standard, and as indicated on the Engineering Flow Diagrams. In case of conflict, this. standard supersedes proposal Engineering Flow Diagrams; however, contract Engineering Flow Diagrams supersede this standard.

II. GENERAL

A. Instrument Terminology

Terminology shall conform to ANSI C85.1 and C85.1a, Terminology for Automatic Control.

B. Flow Diagram Symbols and Instrument Identifications (Tag Numbers)

Flow diagram symbols and identification (tag numbers) for instruments and controls shall be in accordance with ENG STD 60A3, (basically ISA Std. S5.1). Additional symbols required for a specific project shall be explained by additions to ENG STD $60 \mathrm{~A} 3$ as issued for that project.

C. Instrument Index

An Instrument Index listing all instruments for the project and produced by computer shall be furnished.

D. Package Units

1. The instrumentation requirements, when packaged or licensed units are specified, shall conform to this specification wherever possible.

2. Local control panels for package boilers, ccopressors, process heaters, or other units requiring such panels, shall preferably be furniohod by the cquipent vondor. The panelo with the instrumentation therein and the equipment it is to control shall be tested as a unit wherever possible.

III: DESIGN REQUIREMENTS

A. General

1. Tagging

An identification tag shall be attached to each piece of instrumentation equipment. The tags shall be of sturdy, stainless steel or other equaliy weather resistant material, permanently fastened to the material with stainless steel screws or pins. 


\section{Paịting}

Manufacturer's standard colors shall be used for all project instrumentation, including visible portions of instruments mounted on the control panel, unless otherwise specified.

3. Electrical Equipment and Enclosures

All electrical instrument equipment and enclosures for all field mounted or local panel mounted electrical or electronic instruments (or instruments having electrical connections or power) shall conform to the electrical classification assigned to the area in which they are installed, and shall be suitable for outdoor installation if required.

4. Transmitters

a. In general, transmitters shall be of the force balance type or other negligible displacement type, except where such devices are not available or another type of device of proven superior performance is available for a specific measurement. All pneumatic transmitters shall be equipped with an air input gauge as a part of the air supply filter regulators.

b. Process variable indication shall be provided for each transwitter and local controller. This indication shall be either direct reading, or the transmitter output in terms of the process variable.

5. Transmission System

No process fluids of any type shall be piped into the control room. Transmission of the process variable shall be by means of electronic, electric, pneumatic, or thermocouple type instruments. 
ENG STD 60A 1

PAGE 4

REVISION 0

INSTRUMENTATION

DATE May 1,1978

FOSTER WHEELER

PROCESS PLANTS DIVISION

B. Temperature Instruments

1. Strip chart multipoint temperature recorders shall be thermocouple actuated. Recorder points shall not normally be checked by the multipoint plant temperature indicator. The multipoint plant temperature indicator shall be digital type, thermocouple actuated. Range span shall be suitable for use during plant start-up. A multiplex system with remote multiplexers shall be considered.

2. Board mounted temperature controllers shall use temperature transmitters wich are thermocouple actuated. Where required by application, a resistance temperature element may be used.

3. Local temperature controllers having a temperature range span of $400 \mathrm{~F}(200 \mathrm{C})$ or less may use filled system transmitters, limited to a maximum operating temperature of $1200 \mathrm{~F}(650 \mathrm{C})$, provided the direction the instrument is driven in the event of capillary failure does not create a hazardous situation.

4. Thermocouple instruments shall drive to a safe configuration on thermocouple failure.

5. A separate thermowell with thermocouple connected to the multipoint temperature indicator shall be furnished for checking all resistance bulb type temperature transmitters for main panel mounted control applications.

A single thermowell with dual thermocouples shall be furnished for indicator checking of thermocouple actuated panel mounted controllers, transmitters for main panel mounted control applications, or thermocouple actuated switches for main panel mounted alarms and/or interlock circuits. In intrinsic safe applications, a suitable thermocouple head with mechanical barrier or a separate thermowell shall be furnished for checking purposes.

6. The construction and installation of standard thermocouple, thermometer, and test wells shall be in accordance with ENG STD 65811. The standard thermoweil, except pipe type wells, shall be fabricated of Type 304 or Type 316 stainless steel (contractor option), where the nature of the fluid is such as to require other material, the thermowell material shall be suitable for the service.

7. Threaded thermowells shall have $2^{\prime \prime}(50 \mathrm{~mm})$ lagging extention when used with insulation for high temperature. Consideration shall be given for thicker insulation in cold services. 


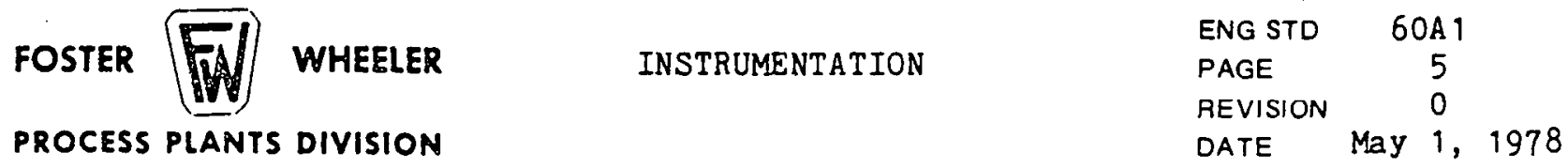

8. Thermowell lengths shall be as shown on ENG STD 65811.1 through 65B11.10. Lengths have not been estabiished for filled system thermowells because of variations in the bulb dimensions.

9. Thermowells for dial thermometers and filled system instruments shall be purchased with the instruments to assure proper fit.

10. Thermowell connections into piping or equipment shall be in accordance with Section $Q$ of this standard.

11. Flanged thermowells shall have flanges and weld filler of the same material as specified for the thermowell only when the well and flange form an integral assembly. Where piping specifications permit a carbon steel flange, the well shall be threaded into a blind flange and shall be backwelded if required.

12. With the exception of wells for bulb type elements, protection wells and test wells shall be $0.26 " 16.6 \mathrm{~mm}$ ) bore to receive bimetallic or sheathed thermocouple type primary elements. All thermowells shall be drilled barstock (no built-up type wells) except pipe type wells.

13. Pipe type thermocouple wells with welded ends shall be furnished for gas temperature measurement at fired heaters, boilers, furnaces, flues, stacks, and large vessels. This also includes those wells used for multiple element thermocouple assemblies in reactors, etc. Well material shall be suitable for the process conditions.

14. Velocity and pressure rating calculations of a thermowell will be performed and compared to the service conditions in those services judged to be critical by the Foster wheeler.

15. Thermocouples shall be furnished with terminal blocks enclosed in a corrosion resistant metallic weatherproof head having a female threaded, gasketed cover. Thermocouple elements shall be in accordance with the ANSI Standard C96.1, "Temperature Measurement Thermocouples." Mineral insulated metal sheathed (normally Type 304 stainless steel) thermocouples shall be used and shall be 1/4" $(6.4 \mathrm{~mm})$ O.D. For general service, the nominal thermcouple wire size shall be 18 AWG but within the temperature limits as recommended by the manufacturer.

16. B1-metallic, fixed stem, dial type gauges furnished with well, shall be used for local temperature indication. Where stem lengths exceeding 24" (610 mm) are required; or where service conditions dictate, thermometers of the filled capillary type may be used. 
ENG STD 6OA 1

PAGE 6

REVISION 0

INSTRUMENTATION

DATE May 1, 1978

FOSTER WHEELER

PROCESS PLANTS DIYISION

C. Flow Instruments

1. Primary Elements

a. Concentric orifice plates shall generally be used as primary elements for flow instruments. In general, Type 304 or 316 stainless steel (contractor option) orifice plates shall be provided. Where the nature of the fluid is such as to require other material, it shall be suitable for the service.

b. Orifice plates shall be in accordance with AGA Gas Measurement Committee Report No. 3, "Orifice Metering of Natural Gas", except they shall be 1/8" thick in sizes $14^{\pi}$ and smaller, and shall be $1 / 4^{\prime \prime}$ thick in sizes $16^{\prime \prime}$ and larger. The minimum orlfice flange size shall be $2^{\prime \prime}$.

c. All primary element calculations shall be in accordance with, "Principles and Practice of Flow Meter Engineering" by Spink, AGA Report No. 3 or manufacturer's special formulas for special elements.

d. Orifices shall be sized so that normal flow rate falis at approximately seven, and minimum flow not less than three, on a 0-10 square root chart. Orifice meter differential range shall be selected for a d/D ratio of 0.75 maximum, and 0.25 minimum. With $2^{\prime \prime}$ pipe and $20^{\prime \prime}(500 \mathrm{~mm})$ or $25^{\prime \prime}(650 \mathrm{~mm})$ of water column differential range, d/D ratios smaller than 0.25 may be used. In any case, actual orifice diameter shail not be less than $0.25^{\prime \prime}(6.4 \mathrm{~mm})$. A differential range of $100 "$ $(2500 \mathrm{~mm})$ of water, dry calibration, shall normally be used for all liquid flow meters. For compressible fluids differential range in inches of water shall not exceed the normal upstream static pressure in psia, except that for exhaust steam, approximately $15 \mathrm{psig}(1.05 \mathrm{~kg} / \mathrm{square} \mathrm{cm}$.$) , 50 "$ (1250 mm) range may ha luser.

e. Special conditions may dictate the use of devices such as the following :

(1) Eccentric or segmental orifice plates shall be used to measure the flow of liquids which contain solids.

(2) Venturi tubes or similar types of flow elements may be used to measure the flow of low pressure gases or liquids where loss of pressure is an important consideration.

(3) Pitot tubes or averaging Pitot tubes such as Annubar may be used to measure flow in certain applications and shall be so indicated on the Engineering Flow Diagrams. 
FOSTER WN WHEELER

PROCESS PLANTS DIVISION
ENG STD $60 \mathrm{~A} 1$

PAGE $\quad 7$

REVISION 0

DATE May 1, 1978

(4) Quadrant edge plates or segmental wedges where viscosity conditions dictate.

2. Meter Runs

a. Line Sizes Up to and Including 10"

Weld neck orifice flange unions having flange taps and a minimum rating of $300 \mathrm{lb} R F$ shall be used. Orifice flange taps shall be 1/2" NPT. Flanges shall be in accordance with AGA Report No. 3, except as noted in paragraph III.C.1.b. above.

b. Line Sizes $12^{\prime \prime}$ and Larger

Line flanges with radius taps shall be used in place of orifice flanges. Radius taps shall be 1 pipe diameter upstream and $1 / 2$ pipe diameter downstream of inlet face. The installation shall be in accordance with ASME Power Test code 19.5, Part 5, Chapter 4, Flow Measurement and "Principles and Practice of Flow Meter Engineering" by L.K. Spink. Connections to piping shall be $3 / 4 "$, with a $1 / 2$ " diameter pressure tap hole.

c. Metering orifices shall not normally be installed in lines less than 2". If the line is less than 2", one of the following devices shall be used:

(1) Swaged (2") meter run

(2) Certifled meter run with corner taps

(3) Rotameter

(4) Integral orifice

3. Meter Run Installations

a. Metering orifices shall be in a horizontal line if possible. If not possible, the installation in a vertical line shall always be upward for liquids and preferably downward for gases.

b. Installation shall be in accordance with ENG STD 65B13.1, through 65813.3, Inst.rument. Piping Standard.

c. Where limited spacing dictates, taps located 45 degrees from the horizontal may be used. 
ENG STD 60A 1

PAGE 8

REVISION 0

INSTRUMENTATION

FOSTER

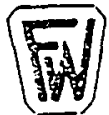

WHEELER

DATE May 1, 1978

PROCESS PLANTS DIVISION

d. The minimum length of straight pipe preceding an orifice plate shall be in accordance with AGA Report No. 3, except for those installations not explicitly covered in the installation sketches, in which case minimum runs shall be in accordance with ASME Power Test Code 19.5, Part 5, Chapter 4, or API Recommended Practice RP 550 .

e. All piping upstream and downstream of orifices shall be in accordance with the piping specifications. Specially selected or machined pipe designed to meet AGA Report No. 3, paragraph III. B shall not be furnished.

4. Instruments

a. Locally mounted flow recorders with pressure pens shall be provided for steam and fuel gas flows to main process units only where shown on Engineering Flow Diagrams. Pressure taps for pressure pens shall be taken from the downstream connection.

b. The flow of main charge and product streams to and from each process unit shall be recorded as shown on Engineering Flow Diagrams. Locally mounted meters shall be provided for streams which are not flow controlled.

c. Force-balance or other negligible displacement type flow measuring instruments shall, shere possible, be selected for all pneumatic or electronic transmitter services.

d. Bellows type manometers shall be used for local differential pressure type indicating and recording instruments if an air supply is not readily available in the area. Normally differential pressure force balance transmitters with local receiver instruments shall be used.

e. Differential pressure instruments shall withstand differential pressures equal to full line pressure without zero or calibration changes. Body materials shall be consistent with the instrument piping material specification.

f. Rotameter type flow instruments may be used for the following:

(1) In pipe sizes, $1 / 2^{\prime \prime}$ and smaller.

(2) For special applications in larger lines where solids are present in the process fluid. 
FOSTER WHEELER
PROCESS PLANTS DIVISION
ENG STD

$60 \mathrm{~A} 1$

INSTRUMENTATION
PAGE 9

DATE MaY 1, 1978

(3) Where an operating flow range exceeds the ratio of 3 to 1 (maximum to minimum). Normal rotameter rangeability is 10 to 1 and the meter shall be selected so that the normal flow falls at at 50 to $60 \%$ of maximum range.

g. Special conditions may dictate the use of devices such as the following :

(1) Turbine meter

(2) Magnetic flow meters

(3) Target meters

(4) Positive displacement meters

5. Instrument Installations

a. All differential pressure type flow meters are to be instalied in accordance with ENG STD 65B12.1 through 65B12.65. Normal installation shall utilize a manifold (similar to Anderson Greenwood M4T for close coupling and $M i$ for remote mounting) and stainless steel tubing.

b. Force balance or other negligible displacement type flow transmitters shall be mounted at the process line, unless such location makes the transmitters inaccessible.

c. Rotameters and rotameter transmitters shall be installed in a manner which permits easy meter or float removal for cleaning or repair purposes. Type and rating of end connections shall be in accordance with the piping specifications.

d. Rotameters (except for purge meters, applications where process conditions dictate otherwise, and in streams that can be temporarily interrupted for service) shall have meter size gate block valves upstream and downstream, and a meter size by-paso with gate valve.

e. For sealed installations, 4" (100 mm) seal pots shall be used for bellows type instruments. No seal pots shall be used with diaphragm type instruments. 
ENG STO 6OA 1

PAGE $\quad 10$

INSTRUMENTATION

FOSTER WIVESTER

REVISION 0

DATE May 1, 1978

PROCESS PLANTS DIVISION

D. Liquid Level Instruments

1. External displacement type level transmitters and controllers shall normally be furnished for all pressure vessels in level ranges equal to or less than 4 feet $(1220 \mathrm{~mm})$. Instrument cases shall be rotatable with respect to vessel connections. Connections on the instruments shall generally be $11 / 2^{n}$ screwed or $11 / 2 "$ flanged, in accordance with the piping specifications.

2. Internal type displacement or ball float type level instruments shall normally be furnished for open sumps and tanks. They may also be used on pressure vessels under special conditions of extreme temperatures, high viscosity, liquids which could boil in an external cage, corrosion, or where other similar process conditions dictate their use. The design selected shall permit removal of the instrument without the need for entering the vessel for prior dismantling. The minimum mounting flange diameter shall be 4". Stilling welis shall be used where the liquid being measured is subject to turbulence.

3. External differential pressure type level instruments shall be furnished for pressure vessels in level ranges which exceed 4 feet (1220 $\mathrm{mm})$, unless process conditions make such types undesirable, and may be furnished for shorter ranges where accessibility makes them preferable. Flange mounted differential type without block valve, or alternately internal displacer type, may be used where process conditions or accessibility make these preferable regardless of range. Flange mounted differential type shall have manufacturer's standard size flanges; flange ratings shall be in accordance with the vessel specifications.

4. Where process conditions dictate and where show on the Engineering Flow Diagrams, capacitance, radioactive, ultrasonic, magnetic float, etc., type of instruments may be used.

5. Float and tape negator spring operated indicators may be used where sultable and where high accuracy is required. Gauge boards may be used on storage tanks where accuracy is not critical.

6. External ball float type level switches shall be flanged body type to permit access to the float without removal of the cage from the piping. Connections shall normally be manufacturer's standard size screwed.

7. Displacer, float, and differential pressure type level instruments shall have cages or bodies and trim material suitable for the process fluid, the temperature and pressure conditions. Minimum trim material shali be stainless steel or other alloy. 
8. Gauge glasses shall be used for local level measurement and shall be sized to cover operating level ranges, not abnormal extremes in level. Where the level range exceeds 11 feet $(3350 \mathrm{~mm})$, the top and bottom 40" (1020 $\mathrm{mm}$ ) shall be covered. Where level is to be controlled between the top and bottom 40" (1020 mm), a gauge glass of suitable length shall also be furnished to cover the controllable range.

9. Gauge glasses shall be armored reflex type for all services except the following, where armored transparent type (without illuminators) shall be used:

a. Interface between liquids.

b. Distillates below 25 degree API Gravity and all crude residuals.

c. Liquids containing gum, sediment, or other solid material which may coat the flutes of a reflex glass.

d. Liquids requiring protecting shields, such as steam above 300 psig $(21.1 \mathrm{~kg} / \mathrm{square} \mathrm{cm})$ or above $15 \%$ caustic solution.

10. Frost shields shall be used if the operating temperature is below $32 \mathrm{~F}(\mathrm{O} \mathrm{C})$.

11. Transparent and reflex gauge glass units shall normally be. fabricated from standard length sections having $117 / 8$ " (300 $\mathrm{mm}$ ) visible length. The maximum unit length shall consist of five glasses. When greater total visibility is required, multiple gauge glass units may be installed either on the vessel or on a pipe column. Chamber connections shall normally be $3 / 4$ " screwed.

12. Gauge glasses for low pressure vessels containing low temperature non-flammable fluids, such as water or phosphate solutions, may be tubular glass type in lengths not exceeding $30 "(760 \mathrm{~mm})$.

13. Level instruments shall be installed in accordance with ENG STD 65B14. 1 through 65B14.40.

14. Connections on vessels shall be in accordance with Section III.Q. of this standard below. 
ENG STD 6OA 1

PAGE 12

REVISION 0

INSTRUMENTATION

FOSTER

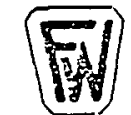

WHEELER

DATE May 1, 1978

PROCESS PLANTS DIVISION

E. Pressure Instrliments (Including Non-Flow Differential Pressure)

1. Win control room board mounted receiver pressure indicators shall normally be furnished for main headers on live and exhaust steam, fuel oil, fuel gas, cooling water, plant air, and instrument air as shown on the Engineering Elow Diagnams.

2. Local pressure gauges shall be Bourdon tube type. Where range requirements cannot be satisfied by sourdon tube gauges, other standard applicable elements shall be used.

3. Pressure measuring elements shall, in general, be Type 316 stainless steel except:

a. Where the nature of the fluid is such as to require other metal, the primary element material shall be suitable for the service.

b. On receiver gauges and diaphragm sealed gauges, where bronze elements may be substituted.

c. On very low pressure ranges, such as for draft gauges or barometrically compensated elements for absolute pressure where alloy steel elements are not available.

4. Sockets shall be of the same material as the primary element and shall be welded to the element using the same fllier material. Brass or bronze elements or sockets may be silver soldered.

5. In general, standard pressure instruments and gauges shall be furnished with full scale pressure ranges having the lower limit of the range equal to zero gauge pressure. Suppressed range pressure instruments may be furnished where required for measurement sensitivity.

6. Locally mounted pressure gauges (except receiver gauges) shall be $41 / 2 "(115 \mathrm{~mm})$ stze. Locally mounted pneumatic receiver gauges shall be $31 / 2 "$ ( $90 \mathrm{mr}$ ). Local electronic receiver gauge scales shall be $21 / 2 "(65 \mathrm{~mm})$ minimum. Panel mounted pneumatic receiver gauges shall be $41 / 2^{\prime \prime}(115 \mathrm{~mm})$, except those mounted within the graphic section which may be smaller.

7. Direct connected pressure gauges shall be provided with blowout backs or discs. Solld front gauges shall be used on all services.

8. Were seal elements are used, they shall be of the continuous duty type, shall be directly connected to the pressure element, and furnished as an integral part. The process connection on the seal shall normally be 3/4" NPT. 


\section{FOSTER \\ 河 \\ WHEELER \\ PROCESS PLANTS DIVISION}

INSTRUMENTATION $\begin{array}{lc}\text { ENG STD } & 60 A 1 \\ \text { PAGE } & 13 \\ \text { REVISION } & 0\end{array}$

DATE May.1, 1978

9. Standard gauge. stem size shall be 1/2" NPT, except receiver gauges shall be $1 / 4$ " NPT.

10. A 1/2" pipe siphon shall be installed adjacent to pressure instruments on steam and other high temperature services when the instrument is close coupled and/or mounted above the tapping point.

11. Pulsation dampers shall be furnished for all pressure instruments and gauges on the discharge of reciprocating pumps, and on the suction and discharge of reciprocating compressors and other pulsating services.

12. Consideration shall be given to the use of Sprague (or equal) gauge savers on pressure instruments when the operating pressure of the service to which the instrument is attached can rise above the maximum working pressure of the instrument.

13. Pressure instruments shall be located so that the head of liquid between the instruments and the point of measurement does not exceed the manufacturer's limit of impressed static head.

14. Connections in piping or equipment for pressure and differential pressure instruments shall be in accordance with section III. $Q$ of this standard.

15. Pressure instruments shall be installed in accordance with ENG STD 65B15.1 through 65B15.51. 
ENG STD 60A 1

PAGE $\quad 14$

REVISION 0 .

DATE May 1, 1978

INSTRUMENTATION

FOSTER WHEEISR

PROCESS PLANTS DIVISION

\section{F. Automatic Controllers}

1. Control modes for other than self-acting regulator type local controllers shall normally be on the following basis:

a. Single Mode (Proportional Band)

(1) Local level controllers

(2) Local pressure controllers

b. Two Mode (Proportional Band Plus Reset)

(1) All panel mounted controllers except temperature

(2) Local flow controllers

(3) Local temperature controliers

c. Three Mode (Proportional Band Plus Reset Plus Derivative)

(1) Ail panel mounted temperature controllers

2. Controllers used for intermittent services such as anti-surge or minimum flow by-passes shall be furnished with anti-reset windup where necessary.

3. Where 4 pipe systems are supplied, the control modes shall be the same as for a panel mounted controller for the same variable.

4. Bumpless transfer switching shall be provided between automatic and manual on all controllers. Controllers shall have provision for adjusting the manual output.

5. Controllers that receive a setpoint signal from an external source shall come equipped with a local/remote setpoint switch, and permit bumpless transfer between setpoint sources.

6. Control function settings, such as setpoint and manual output, manual-automatic transfer switch, etc., shall be located on the front of all panel mounted controllers.

7. Setpoint, process variable, deviation, and continuous controller output indications shall be from the front panel of all panel mounted controllers.

8. Receiver controllers shall be elther the indicating process type with a separate or integral recorder, where a recorder controller is specifled, or shall be the indicating deviation type.

9. Panel mounted controllers shall preferably be of the selfcontained type with removable chassis. 


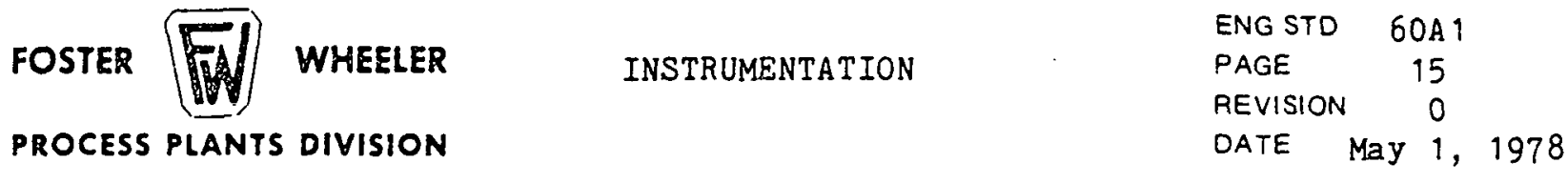

10. Panel mounted instruments shall be provided with tag number identification on both front and rear.

G. Recorders, Chart Drivers, Scales and Charts

1. Local recorders shall, in general, be of the large case type.

2. Chart drives for main board mounted instruments shall be electric motors. Chart drives for locally mounted instruments and local panel mounted instruments shall be electric motors conforming to the electrical area classification assigned to the area in which they are installed; or where electricity is not adequate to permit use of symchronous motors, ?-day spring wound type may be used.

3. A 30-day supply of charts shall be furnished with each recording instrument.

4. Scales and Charts

See following page. 
ENG STO 60A 1

PAGE 16

REVISION 0

INSTRUMENTATION

DATE MaY 1, 1978

FOSTER WHEELER

PROCESS PLANTS DIVISION

All charts and scales for direct reading instruments shall use the units shown below. Charts and scales for other instruments shall have factors to convert to the units shown below:

\begin{tabular}{|c|c|c|c|c|}
\hline VARIABLE & ENGLISH UNITS & METRIC UNITS & SCALES & CHARTS \\
\hline Temperature & Degrees $F$ & Degrees C & $D R$ & $0-100$ un. \\
\hline $\begin{array}{l}\text { Pressure } \\
\text { Near Atmos. } \\
\text { Above Atmos. } \\
\text { Below Atmos. } \\
\text { Absolute }\end{array}$ & $\begin{array}{l}\text { In. of water } \\
\text { psia } \\
\text { In. of } \mathrm{Hg} \\
\text { psia or in. } \mathrm{Hg} \\
\text { absolute }\end{array}$ & $\begin{array}{l}\text { mm of water } \\
\mathrm{kg} / \mathrm{sq} \cdot \mathrm{cm} \cdot \mathrm{G} \\
\mathrm{mm} \mathrm{Hg} \\
\mathrm{kg} / \mathrm{sq} \cdot \mathrm{cm} \cdot \mathrm{A} \cdot \mathrm{or} \\
\mathrm{mm} \mathrm{Hg} \text { absolute }\end{array}$ & $\begin{array}{l}D R \\
D R \\
D R \\
D R\end{array}$ & $\begin{array}{l}0-100 \text { un. } \\
0-100 \text { un. } \\
0-100 \text { un. } \\
0-100 \text { un. }\end{array}$ \\
\hline Level & $\begin{array}{l}\text { \% of range for } \\
\text { Process; feet } \\
\text { and inches of } \\
\text { actual height } \\
\text { for storage } \\
\text { tanks where } \\
\text { precise } \\
\text { inventory is } \\
\text { required. }\end{array}$ & $\begin{array}{l}\text { of range for } \\
\text { Process; mili- } \\
\text { meters of actual } \\
\text { height for } \\
\text { storage tanks } \\
\text { where precise } \\
\text { inventory is } \\
\text { required }\end{array}$ & $\begin{array}{l}0-100 \text { un. } \\
\text { or } f t \text {. and } \\
\text { in. (mm) }\end{array}$ & $0-100$ un. \\
\hline
\end{tabular}

Flow

Steam and Boiler

Feed Water

Ibs/hr

$\mathrm{kg} / \mathrm{hr}$

0-10 s.r. $0-10$ s.r.

Liquids

U.S. GPM

liter/min.

$0-10$ s.r. $0-10$ s.r.

Water

U.S. GPM

Gas or Vapor

SCEH *

liter/min.

$\mathrm{N}$ cu.m./hr

$0-10$ s.r. \$ $\$ 0-10$ s.r. \#\#

Air and Nitrogen SCFH

$\mathrm{N}$ cu.m./hr*

0-10 s.r. $0-10 \mathrm{s.r}$.

$0-10$ s.r. $0-10$ s.r.

Rotameters

Unit as above

Unit as above

$0-100$ un. 0-100 un.

Analyzers

pH, \& oxygen,

$\mathrm{pH}, \$$ oxygen,

DR

$0-100$ un.

NOTE:

Defined as at $60 \mathrm{~F}$ and 14.7 psia or $0 \mathrm{C}$ and $760 \mathrm{~mm} \mathrm{Hg}$.

* Direct Reading on transmitter.

1* 0-100 uniform if transmission system includes a square root extractor.

DR - Direct Reading

s.r. - Square root

un. - uniform 


$\begin{array}{llll}\text { FOSTER WHEELER } & & \text { ENG STD } & 60 A 1 \\ & \text { INSTRUMENTATION } & \text { PAGE } & 17 \\ \text { PROCESS PLANTS DIVISION } & \text { REVISION } & 0 \\ \text { DATE } & \text { MaY } 1,1978\end{array}$

H. Transmission Systems

1. General

a. Local field mounted control loops shall be pneumatic. Transmitters used with local field mounted control loops shall be pneumatic.

b. With electronic control room instrumentation, pneumatic-tocurrent transducers shall be used where signals from local pneumatic loops are transmitted to the control room.

c. Each field mounted transmitter, controller, control valve positioner, and other air consuming device, shall be provided with its own filter regulator air set.

2. Pneumatic Transmission

a. Output signal from all transmitters shall normally be 3 to 15 psig (or 0.20 to $1.00 \mathrm{~kg} /$ square $\mathrm{cm}$ ), unless manufacturer's standard or other considerations require otherwise. Instrument air connections shall be $1 / 4 "$.

b. All pneumatic receiver instruments and gauges shall normally have receiver elements designed for 3 to 15 psig (or 0.20 to $1.00 \mathrm{~kg} /$ square $\mathrm{cm}$ ) input air signal, unless manufacturer's standard or other considerations require otherwise.

c. For flow or liquid pressure control where tubing length between control room and field transmitter and/or valve exceeds 350 feet $(106,680 \mathrm{~mm})$, and only if specified by Foster Wheeler, the control mechanism y be located at the transmitter or control valve.

d. Individual pneumatic transmission tubing shall be $1 / 4^{\prime \prime}$ O.D. $x$ 0.030 " wall ( $4 . \times 6 \mathrm{~mm}$ ) copper in accordance with the piping specifications. PVC coated copper shall normally be used if the atmosphere is corrosive to copper. Aluminum or polyethylene may be used as an alternative.

e. Individual tubes may be brought to field junction boxes and bundled fire resistant polyethylene tube assemblies, Dekoron Type $B$ or equal, (with $10 \%$ spares) used between the junction boxes and the control panel bulkhead fittings. 
ENG STD 60A 1

PAGE 18

REVISION 0

INSTRUMENTATION

FOSTER FU

WHEELER

DATE May 1, 1978

PROCESS PLANTS DIVISION

f. Instrument tubing supports shall be fabricated in accordance with ENG STD 68B11.1 through 68B11.14. Supports shall be fabricated from standard structural members. Special shapes, such as "Unistrut", shall be used only for clamp supports. This standard does not provide for special tubing troughs such as "Instrof". Messenger cable may be used for support of bundled tubing where pipe racks are not readily availabie.

8. Small groups of tubes shall be supported either from the air supply piping with messenger clips, plastic or metal strips, or in tube race channels suitably braced to structural supports.

3. Electronic Transmission

a. Regulatory Codes

(1) Unless otherwise specified, all electrical Instrument facilities shall comply with the applicable recuirements of the latest edition of the National Electrical Code and applicable local codes.

(2) Where applicable, the design and installation of the materials shall be guided by recommended practices of the ISA and API RP 550, Part.I.

b. General

(1) Electronic panel instruments shall generally be compatible with each other, with field instruments and other devices used on the project, without the use of signal converters. It is desirable that electronic panel instruments, signal converters, function modules, etc. be supplied by the same vendor.

(2) Signal ranges for electronic process control instruments shall be 4-20 ma DC with common negative.

(3) Where possible, all field mounted electronic instruments shall eloloy a true two-wire transmission system.

(4) Instrument.s that are mounted in NEC, Class I, Division 1 locations shall be explosion-proof or intrinsically safe. However, instruments that are not readily available in explosion-proof construction, such as some analyzers, will be considered acceptable for Division 'i locations when totally enclosed and purzed with instrument air. With loss of purge, the instrument will be de-energized and an alarm circuit actuated per ISA S12.4 Type $X$. 
FOSTER WHEELER

PROCESS PLANTS DIVISION
INSTRUMENTATION
ENG STD $6 O A 1$

PAGE

REVISION

DATE May 1, 1978

(5) Instruments for Division 2 areas shall be treated in a. similar way except that loss of purge shall only actuate an alarm per ISA $\$ 12.4$ Type $Z$.

(6) Purging system design shall meet the requirements of ISA STD 12.4 and NFPA 496.

(7) Where specified as an intrinsically safe installation, all control room instrumentation and associated field transmitters shall be solid state, intrinsically safe, electronic type. All equipment, material, and installation procedures shall be certified as complying with the requirements of NFPA 493, and of the particular vendor's approved design. Approval and/or certification of intrinsically safe process control equipment must come from a nationally recognized laboratory, such as UL, FM, American Gas Association Laboratories, UL of Canada, CSA Testing Laboratories, etc. The primary instrument vendor shall review and provide written certification that loop schematics and wiring diagrams meet the vendor's system design requirements. All instrument installations shall satisfy any existing local codes. Intrinsic safety through the use of barrier devices is desirable.

(8) Electropneumatic transducers or positioners shall be furnished for control valves which are operated by electronic signals.

(9) Instruments shall be suitable for operation from a central power supply, either AC or DC as required.

(10) Thermocouple and voltage signal receivers shall have an input impedance of more than 100 times the impedance in the rest of the circuit. This includes the wiring and the output impedanse of the signal source.

(11) Controllers, recorders, indicators, computer inputs, alarm relays, etc., shall operate on voltage signal measured across vendor-specifled calibrated resistors or other electronic devices. 
ENG STD60A 1

PAGE 20

REVISION 0

DATE May 1, 1978

\section{FOSTER WHEELER \\ PROCESS PLANTS DIVISION}

c. Power Supply for Panel Mounted Instruments

(1) Panel mounted electronic instruments may be provided with or without integral power supply. Power supply for panel mounted instruments and field mounted transmitters shall be located in the control house.

(2) Instrument power transforming and stabilization system shall be provided, as required.

(3) Power supply back-up. system will rot be provided except where specifically defined in the Proposal or Job Specifications.

(4) Instrument power supply systems shall be designed in accordance with the instrument vendor's recommendations.

(5) In general, $D$ power is derived from AC power by rectifying and filtering. The output of this power supply shall be regulated for AC line variations in accordance with instrument vendor's specifications.

d. Electronic Transmission Wiring

(1) Installation of thermocouple lead and electronic transmission wiring shall be in accordance with ENG STD $60 \mathrm{A2}$. 


\section{FOSTER FA WHEELER \\ PROCESS PLANTS DIVISION}

ENG STD $\quad 60 \mathrm{~A} 1$

PAGE 21

REVISION 0

DATE May 1, 1978

J. Alarms and Signals

1. Alarm and signal systems shall be considered those audible and visual requirements for alerting operating personnel of the need to take corrective process action or to be advised of an operating condition which is deviating from preset limits.

2. Alarm and signal elements shall be actuated from pneumatic or electronic receiver switches located in the control room where there is a receiver instrument on the instrument panel. Where the loop is local only with remote alarm, the switch shall be located in the field. Where there is no transmitted signal, alarm and signal elements shall be actuated from a separate primary instrument.

3. The alarm and signal system shall be solid state and shall include back-lighted window annunciators, horn or buzzer, signal acknowledgement, test and reset (where required) buttons for indication of an abnormal operation condition on the main panel, and back-lighted window annunciators or bull's-eyes on local panels. $20 \%$ spare unequipped alarm windows shall be provided.

4. All trouble contacts actuating alarms shall be initiated by the opening of contacts which are closed during normal operation.

5. Enclosures for field mounted electrical instruments shall be rated in accordance with the electrical classification assigned to the area in which they will be installed and shall be suitable for outdoor installation, if required.

6. Alarms shall operate under the same condition as the equipment they protect, such as through power failure; i.e., if equipment continues to operate through power failure, its associated alarms must also operate through power failure.

7. Where one abnormal condition may cause a sequence of events resulting in several alarm signals at almost the same time, a "first-out" system shall be furnished. As an example, the initiating abnormal conditions are indicated by a flashing light and subsequent abnormal conditions are indicated by flashing at a different rate until the upset is acknowledged. When the alarm is acknowledged, the audible device will be silenced, but the alarm light shall still be distinguished from the subsequent alarm lights, acknowledged or not acknowledged.

8. All devices which shut down major items of equipment shall alarm at the time of shutdown, on a first-out sequence annunciator system as described in Paragraph III.J.7 above. This must be in addition to any pre-shutdown alarm. 
ENG STD60A 1

PAGE 22

REVISION 0

DATEMay 1, 1978

9. Installation of intrinsically safe alarm and signal wiring shall be in accordance with ENG STD 60A2. Installation of nonintrinsically safe alarm and signal wiring shall be in accordance with ENG STD $70 \mathrm{~A} 1$.

K. Emergency Systems

1. Emergency systems shall be considered those requirements for initiating automatically an action to prevent a hazardous condition or situation from developing, or to prevent or reduce further operating upset.

2. The emergency system shall be of the normally energized type, i.e., actuation of emergency action shall be initiated by the opening of contacts which are closed during normal operation.

3! Emergency system (trip) elements shall be actuated from separate primary instruments, except in flow measurement,

differential pressure measurement, and analyzer applications, in which case associated primary instruments may be used. Emergency system (trip) elements shall be furnished with SPDT switches, where an alarm and a trip function are actuated from a common primary instrument, the common element shall actuate a DPDT isolating relay. Trip element contact ratings shall be suitable for the devices they are actuating, e.g., electrical switch gear.

4. Enclosures for field mounted electrical instruments shall be rated in accordance with the electrical classification assigned to the area in which they will be installed and shall be suitable for outdoor installation, if required.

5. Protective devices shall be independent of all other instrumentation. Shutdown interlock (protective) systems shall have a separate, isolated power source. 


\section{Control Valves}

1. Wherever practical, all control valves shall be of the spring and diaphragm pneumatically actuated type. Consideration of piston type actuators, with or without helper springs and/or fail-safe capacity tanks, shall be given for speclal applications if their fallure cannot jeopardize plant safety. Control valve trim and body style shall be determined by the application.

2. Control valves shall usually be sized for a nornal flow at no more than $70 \%$ of the capacity of the valve, with no less than one quarter of the total system friction pressure drop or $10 \%$ of operating pressures to $1000 \mathrm{psig}(70.3 \mathrm{~kg} /$ square $\mathrm{cm})$, whichever is greater, alloted to the valve. Above $1000 \mathrm{psig}(70.3 \mathrm{~kg} / \mathrm{square}$ $\mathrm{cm}$ ) a lower percentage of the operating pressure may be used for valve differential pressure depending on process and control considerations. Butterfly valves shall be sized for a maximum flow at 60 degree angular opening, except for a characterized vane valve (such as the "fishtail") which may be sized at go degree angular opening. Three-way valves shall be sized to pass maximum flow through either port with minimum available pressure drop through the same port.

3. A noise prediction calculation shall be performed for all control valves. A mechanical or piping modificaton, or both, shall be made to conform to O.S.H.A. regulations in Sound Pressure Level (SPL) so as not to exceed $90 \mathrm{dBA}$ at 3 feet, the plant noise level or more restrictive regulatory rules which apply. Where the noise level exceeds this limit, noise abatement procedures or mechanical valve modification, or both, or special valves, shall be used.

4. Diaphragm motors normally shall be the fully enclosed spring type. Springs shall have linear characteristics permitting full stem travel under operating conditions for signal air pressure range of 3 to $15 \mathrm{psig}(0.2$ to $1.0 \mathrm{~kg} /$ square $\mathrm{cm})$ or 6 to 30 psig $(0.4$ to 2.0 $\mathrm{kg} / \mathrm{square} \mathrm{cm})$. Springs shall be corrosion resistant and shall have a readily accessible adjusting nut. Stem position indicators shall be provided. 
ENG STD 60A.1

PAGE 24

REVISION 0

DATE May 1, 1978

5. The valve actuator shall be sized to fully stroke the valve against the unbalanced forces acting on the valve plug and stem when the differential pressure across the valve is equal to 110 \% of the normal operating upstream pressure or the maximum differential pressure that can be experlenced in the field (e.g., maximum torque requirement of a butterfly valve; shutoff pressure of a pump during start-up with the recefver at atmospheric pressure or vacuum), wichever is greater. In addition to these forces, allowance shall be made for hysteresis in the movement of the valve components and weight of the moving parts. Loading relays shall not be used to increase stem force in lieu of larger size topwork. Any combination of loading relay and topwork requires Foster wheeler approval. The valve vendor's standard method of actuator sizing may be used. The cold bench set of the valve spring shall not vary by more than $10 \%$ from the spring range requirements for operating pressure.

6. The minimum size for control valves shall normally be $1^{\prime \prime}$ in line sizes $1^{n}$ and larger. In lines smaller than $1^{n}$, a line size control valve shall normally be furnished. Valves $11 / 4^{n}, 21 / 2^{n}$, and $5^{\prime \prime}$ shall not be used. Reduced trim shall be specified when the required valve capacity is below these sizes.

7. Normally, all control valves shall be flanged, except valves such as butterfly, rotary, or ball may be wafer type designed to fit between companion flanges. All flanged control valves shall have face-to-face dimensions in accordance with ISA RP 4.1 wherever practicable.

8. Control valves in process services shall have steel bodies unless the piping specifications require alloy. In water, air or low pressure steam lines where the piping specifications permit, control valve bodies may be cast iron.

9. The minimum flange rating for valves 4" size and smaller shall be 300 lo RF in accordance with ANSI B 16.5 for steel or alloy valves, and 250 Ib RF in accordance with ANSI B16. 1 for iron body valves. For larger sizes the pressure rating shall conform to the piping specifications. The rating for butterfly valves shall conform to the piping specifications, regardless of size.

10. Control valve trim shall be stainless steel as a minimum. Hardened stainless steel or stellite facing shall be furnished for valve plugs, seat rings, guide posts and bushings for pressure drop which exceed 150 psi $(10.5 \mathrm{~kg} / \mathrm{square} \mathrm{cm})$, fllashing liquid services, and for fluids which contain solid particles. 


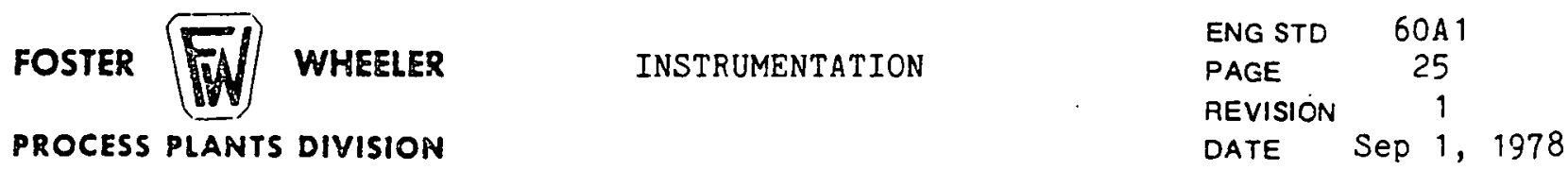

11. Control valves shall be furnished with packing glands and teflon or teflon-asbestos packing for operating temperatures below $450 \mathrm{~F}$ $(232 \mathrm{C})$. For $450 \mathrm{~F}(232 \mathrm{C})$ and above, asbestos packing with grease seal lubricator, and isolating valve shall be furnished. Selected vendor's recommended packing for this service may supersede this Paragraph.

12. Radiation extension bonnets shall be provided for operating temperatures of $450 \mathrm{~F}(232 \mathrm{C})$ or higher and for operating temperatures of $32 \mathrm{~F}(\mathrm{O} \mathrm{C})$ or lower. Selected vendor's recommendations may supersede this Paragraph.

Double-seated globe type control valves shall be top and bottom guided. Single-seated globe type control valves shall be top, top and bottom, or cage guided.

13. Pneumatic valve positioners shall have 3 pressure gauges (2 for electropneumatic). Bypass valves shall be provided except on split range positioners or where the operator is other than 3-15 psig $(0.2$ to $1.0 \mathrm{~kg} /$ square $\mathrm{cm})$. Valve positioners shall be furnished for throttling automatic control valves only under the following conditions:

a. Slow response service, such as temperature or averaging liquid level control.

b. Venturi throat, three-way, and butterfly valves.

c. Unbalanced single-seated yalves larger than 1"!

d. Valves in split range services.

e. Coking, crystallizing, gumming, or slurry service.

NOTE: For fast response services where valve positioners cannot be used, but where the operator is other than 3-15 psig $(0.2$ to $1.0 \mathrm{~kg} / \mathrm{square} \mathrm{cm}$ ) and/or where an increased volume of air to the operator is required to increase valve stroking speed, an instrument air relay or a volume booster may be required.

14. All control valve bodies $11 / 2^{\prime \prime}$ size and smaller shall be furniohed with block and bypass valves in accordance with Paragraph III.L. 17 below. 
ENG STD 60A 1

PAGE 26

REVISION 0

DATE May 1, 1978

15. Control valves in corrosive, erosive, or other services shall be furnished with block and bypass valves only where shown on Engineering Flow Diagrams. A corrosive service shall be defined as one in which the process fluid is more corrosive to the wetted parts of the valve than to the piping. Erosive service shall be defined as one where the line fluid contains solids or where the normal operating pressure drop across the control valve exceeds $150 \mathrm{psi}(10.5 \mathrm{~kg} / \mathrm{square} \mathrm{cm})$.

16. Normally, when the control valve is $2^{\prime \prime}$ or larger and except when the above Paragraph III.L.15 applies, block and bypass valves shall be omitted. The control valve shall be furnished with a continuously connected hand wheel operator except for rotary-motion type valves and electrical motor-operated valves which may use declutchable handwheels if necessary.

17. Size of block and bypass valves shall be determined by the size of the control valve body and line size per the following table:

RECOMMENDED MINIMUM BLOCX AND BYPASS VALVE SIZING

FLEXIBLE DESIGN

LINE SIZE:

$1 / 2$

VALVE

CONTROL

VALVE SIZE
$1 / 2$

$3 / 4$

1

$11 / 2$
BLOCK BYPASS

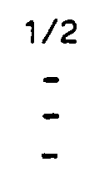

$3 / 4$

VALVE

BLOCK

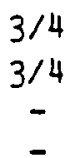

1

VALVE BLOCK BYPASS 


\section{FOSTER WHEELER \\ PROCESS PLANTS DIVISION}

ENG STD $60 \mathrm{~A} 1$

INSTRUMENTATION

PAGE 27

REVISION 0

DATE May 1, 1978

LINE SIZE:

$11 / 2$

2

3

4

VALVE

VALVE

CONTROL

BLOCK BYPASS

BLOCK BYPASS

VALVE

BLOCK BYPASS

VALVE

VALVE SIZE

\begin{tabular}{|c|c|c|}
\hline $1 / 2$ & $11 / 2$ & $11 / 2$ \\
\hline $3 / 4$ & $11 / 2$ & $11 / 2$ \\
\hline 1 & $11 / 2$ & $11 / 2$ \\
\hline $11 / 2$ & $11 / 2$ & $11 / 2$ \\
\hline 2 & - & 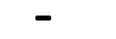 \\
\hline 3 & - & - \\
\hline 4 & - & - \\
\hline 6 & - & - \\
\hline
\end{tabular}

LINE SIZE:

6

8

12

VALVE

CONTROL

BLOCK BYPASS

VALVE

BLOCK BYPASS

VALVE

VALVE SIZE

$\begin{array}{rr}1 & 1 / 2 \\ 2 & \\ 3 & \\ 4 & \\ 6 & \\ 8 & \\ 0 & \\ 12 & \end{array}$

$\begin{array}{ll}-4 & - \\ 4 & 4 \\ 6 & 4 \\ 6 & 6 \\ - & - \\ - & - \\ - & -\end{array}$

10

VALVE

$\begin{array}{ll}- & - \\ - & - \\ 2 & 2 \\ 3 & 2 \\ 3 & 3 \\ - & - \\ - & -\end{array}$

BLOCK BLOCK BYPASS

NOTE: All sizes in inches

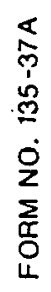

a . Bypass valves shall be globe type in sizes up to and including 4" bypass valve size, and gate type in sizes larger than $4 "$.

b. Block and bypass valves and manifolds shall not be larger than main line size.

c. Increase bypass valve body size one size where control valve body is butterfly design (only wen globe valves are used as bypass).

d. On flashing service or where the control valve outlet main line size is greater than the control valve inlet main line size, the outlet piping from both the control valve and bypass valve, and the downstream block valve itself, shall be no smaller than one size less than outlet main line size. 
ENG STD $60 \mathrm{~A} 1$

PAGE 28

REVISION 1

DATE SeP 1, 1978

18. Screwed or socket weld control valves, if used, shall have flanges or unions immediately adjacent to the valve for removal purposes.

19. A $3 / 4^{n}$ drain consisting of pipe nipple and gate valve shall be provided immediately upstream for each control valve.

20. Hand control valves shall have the same characteristics as motoractuated valves except for the handwheel and fine-threaded stem. Valve position indicators mounted on the actuator yoke shall be furnished.

21. Self-actuated regulators may be used for services where a variation of 10\% above or below the set point is not objectionable. Special sizing is required to maintain these allowances.

(1)

22. Use of self-actuated regulators may require exceptions to Paragraphs III.L.8 and III.L.9 above.

23. All control valve arrangements and details shall be in accordance with ENG STD 50B16.1,50B16.2, 50816.3 and in accordance with the Engineering Flor. Diagrams. 
M. Pressure Relleving Devices

1. The selection, sizing, design, and instailation of relief valves, rupture discs, and relieving systems shall be generally in accordance with API RP 520; Sections I and VIIJ of the ASME Boiler and Pressure Vessel Code, or any other applicable piping or vessel code. In general, valves shall have metal-fo-metal seating surfaces. Soft seats, linings, etc. may be required for special services such as slurries.

2. All rellef valves except those on water, steam, and air shall, as a minimum, be steel with stainless steel disc and guides.

3. Relief valves on water, steam, and air may be turnished with iron, brass, or bronze bodies as allowed by the piping apecification for the service conditions.

4. Thermal expansion valves will be provided only when shown on the Engineering Flow Diagrams.

5. Refer to ENG STD 5OA 1 for relief valves on turbirse exhaust piping.

6. Tank venting shall be provided in accordance with the API Std. 2000, "Venting Atmospheric and Low-Pressure Storage Tanks."

7. All relief valves shall be manufacturer'3 standard types as recommended for the specified services. These valves shall conform to the following:

a. API Std. 526 - "Flanged Steel Safety Relief Valves" for materials and sizes on flanged valves

b. API Std. 527 - "Commercial Seat Tightness or Sarety Relief Valves with Metal-to-Metal Seats" for permissible leakage

8. Relief valves which discharge to the atmosphere through discharge piping shall have the pipe extend at least 10 feet $(3050 \mathrm{~mm})$ above any platform or working area within a 25 feet $(7600 \mathrm{~mm})$ radius of the point of discharge. Relief valves shall have a minimum of piping between the protected line or equipment and the valve inlet. The low point of the outlet piping shall be provided with a $3 / 81(10 \mathrm{~mm})$ minimum weephole when discharging to atmosphere. The end of atmospheric vents shall be square across the end. The inlet to each relief valve and all vents connected to closed systems shall drain away from the valve. 
ENG STD 60A 1

PAGE $\quad 30$

INSTRUMENTATION

FOSTER

s.t.

WiAEELER

REVISION 0

DATE May 1, 1978

PROCESS PLANTS DIVISION

N. Control Panels

1. The control room shall house the main control panel.

2. The control room shall have a "General Purposen classification.

3. The general arrangement and dimensions of the main instrument panel shall be in accordance with Type "A" as illustrated hereafter in this standard.

4. All other auxiliary instrument panel boards, such as those furnished for local location near equipment 1tems, shall be Type "A" or "B".

5. Fabrication and finishing of all instrument panels shall be equal to that specified in ENG STD 64A1. "Except on panel Types "C" and "D", the instrument bezels shall be finished with manufacturer's standard color.

6. Instruments shall be located on all panels for convenient ooservation and operation. As far as possible, the horizontal instrument arrangement shall follow the process flow path frow left to rigint.

7. Instrument density on panels allows for at least $5 \%$ spare panel instrument space for future instruments.

8. Process lines and symbols for panel Types "C" and "D" shall be removable adhesive-backed plastic. Alternatively, other raised lines and symbols made from aluminum or formica may be used.

9. Engraved identification plates shall be provided for all instruments except where provided as part of the instrument.

10. Instruments shall be provided with tag number identification on both front and rear.

11. One twelve-hour electric motor clock shall be furnished for each control room.

12. Refer to ENG STD $47 \mathrm{~A} 2$ and $47 \mathrm{~A} 3$ for front and rear panel clearance dimensions. 


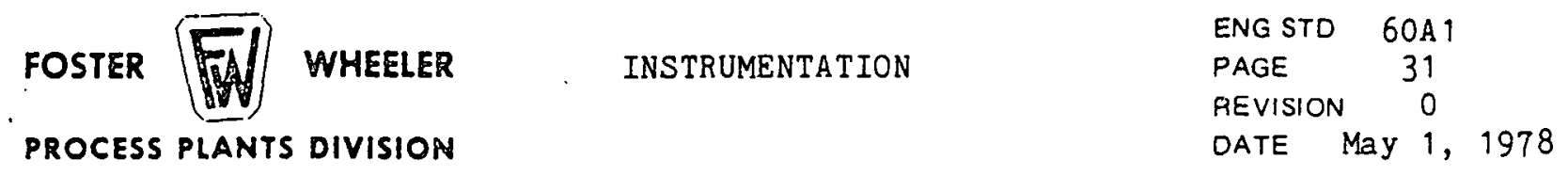

P. Analyzers

1. Analyzers shall be furnished in accordance with the Engineering Flow Diagrams.

2. Analyzers with their sampling systems shall be normally purchased as installed systems, with provision for start-up and operating responsibility by the analyzer vendor or subcontractor. Necessary calibrating gases and/or liquids shall be part of this purchased package.

3. Analyzer installations shall generally be in accordance with API RP 550, Part II.

4. Where required, analyzers shall have a dedicated recorder suitable for calibration and display.

5. The sampling system shall generally conform with API RP 550, Part II. The system shall preferably be obtained from the analyzer vendor. If this is impractical, the system design shall be supplied or approved by the analyzer vendor. Each proposed sample system shall be described in detail, in writing, for final Foster Wheeler approval prior to purchase.

6. Provision shall be made for manual injection of a standard sample for calibration and check purposes.

7. Refer to API RP 550, Part II, for a description of sample probes. An ASTM type nozzle shall be used for liquids and the typical gas sample probe for gases. If threaded joints are not applicable, use $11 / 2 "$ flanged connections.

8. The analyzer operation shall not be affected by:

a. Ambient or sample temperature fluctuations.

b. Barometric or sample pressure changes.

9. All materials shall be suitable for the sample stream and the surrounding atmosphere.

10. Where specified, analytical detector systems shall be installed in noncombustible, weatherproof, heated, well ventilated and/or air conditioned walk-in type houses provided with all necessary utilities and with sufficient space for adequate access to ali parts of the analyzer. Analyzer installation shall be located to minimize obstruction to other equipment. 
ENG STO 60A 1

PAGE 32

REVISION 0

DATE May 1, 1978

11. The minimum specifications for the above analyzer buildings shall be as follows:

a. Steel frame, galvanized (16 gauge) siding and roof, sheet steel door. Heat (25 psig or $1.76 \mathrm{~kg} / \mathrm{square} \mathrm{cm}$ steam) is required to maintain $60 \mathrm{~F}(16 \mathrm{C})$ when the ambient temperature is $33 \mathrm{~F}(0 \mathrm{C})$. Provide gravity ventilation for air circulation. Provide adequate lighting. Provide a floor drain.

12. A power isolating switch shall be included at the local analyzer installation in the field and also in the control room.

13. Where applicable, analyzer buildings may be furnished by the analyzer vendor as subcontractor. 


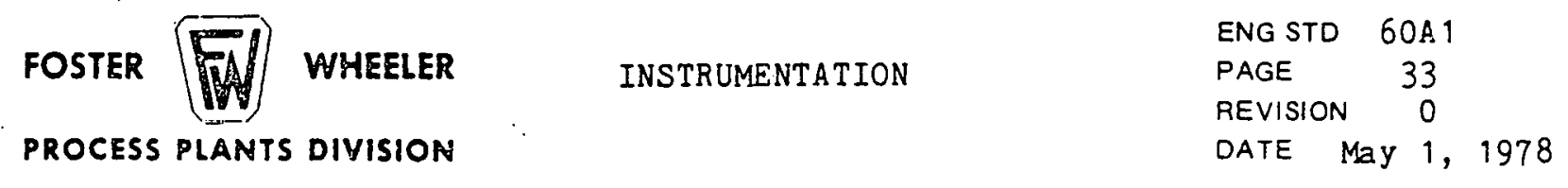

Q. Connections for Instruments on Vessels and Piping

Temperature Wells (see Note 9)

Piping and Vessels $6001 \mathrm{~b}$ and $800 \mathrm{~F}$ or lower carbon steel $\eta^{\prime \prime}$ scrd. (1) (6)

Alloy for hydrogen service

Above $6001 \mathrm{~b}$ and $800 \mathrm{~F}$

All lined piping or vessels

Stainless steel piping or vessels

Duct or stack

1 1/2" flgd.

$11 / 2$ " flgd.

1 1/2" flgd. (except where minimum size is $2^{\prime \prime}$ )

1 1/2" flgd.

$11 / 2 "$ serd.

Orifice Piping

Flange Taps (below 900 1b)

Flange Taps (900 $1 \mathrm{~b}$ and above)

Pipe Taps

$1 / 2 "$ scrd. (3)

3/4" serd. (3)

3/4" serd. or S.W. (3) (8)

Pressure Taps (including diff. press.)

Piping

Vessels

Duct, Stack, or Heater Wall

3/4" serd. or S.W. (4)

3/4" serd. or S.W. (10)

$11 / 2 "$ scrd. (with sleeve

thru refractory if required)

Level Instruments

External Displacer

Internal Displacer

Diff. Pressure Taps

Diff. Pressure with Dip Tube

Diff. Pressure, Flange Mounted

Flush Diaphragm

Diff, Pressure, Flange Mounted

Extended Diaphragm

Internal Ball Float

3 1/2" O.D. Ball

5" O.D. Ball

Level Suitches, Internal Float

Level Switches, External Float

Dielectric Probe and Conductivity

1 1/2" serd. or S.W. (1)

4" flgd.

3/4" serd. or S.W. (10)

4" flgd.

Mfr. Sto.

Mfr. Std.

4" flgd.

6" flgd.

4" fled.

1" Serd. or S.W. (10)

Mfr. Std. 
Gauge Glasses

Gauge Glass only

Single Gauge Glass, where piping projection exceeds 15"

Gauge Glass and Displacer

Gauge Glass Standpipe

$3 / 4 "$ serd. or S.W. (10)

$11 / 2^{\prime \prime}$ serd. or S.W. (10)

2" flgd.

2" flgd.

NOTES:

1. If screwed or socket weld connections are not permitted, $11 / 2^{n}$ flanged connections shall be furnished.

2. If screwed or socket weld connections are not permitted, 2" flanged connections shall be furnished.

3. For horizontal meter runs, orifice taps shall preferably be located on the horizontal centerline for liquid steam services, and on the top vertical centerline for gas services. Where piping clearances are a factor, taps may be located 45 degrees from the horizontal centerline, above or below as indicated by the location of the differential pressure measuring device.

4. The type of connections for pressure taps shall conform to the appropriate piping specifications.

5. Materials of construction shall be as per the piping specification.

6. No back-welding of threaded connections shall be permitted.

7. Ratings of all flanged connections shall conform to the appropriate piping or vessel specification.

8. 1/2" hole drilled in pipe wall.

9. Connections for multipoint thermowells, retractable, purged and skin temperature thermowells shall be selected to suit manufacturer's standard equipment.

10. If screwed or socket weld connections are not permitted, in flanged connections shall be used. 


\section{FOSTER}

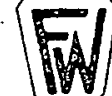

WHEELER

PROCESS PLANTS DIVISION
ENG STD . 60A 1

INSTRUMENTATION $\begin{array}{lrl}\text { PAGE } & 35 \\ \text { REVISION } & 0 \\ \text { DATE May } & 1,1978\end{array}$

R. Inștrument Air Supply

1. The main instrument air supply shall be furnished without interruption from other general air user requirements. The instrument air supply shall be distributed at nominally 100 psig $(7.03 \mathrm{~kg} /$ square $\mathrm{cm})$. An instrument air supply drier system designed to deliver $110 \%$ of maximum system requirements shall be supplied.

2. Instrument air shall be dehydrated to a dew point of approximately $40 \mathrm{~F}(4.44 \mathrm{C})$ below area average cold season temperature.

3. For ten or more pilot users the dry air supply to a control panel shall be from a single pressure reducing station, with filter, upstream and downstream block valves. A spare reducing valve, filter and block valves shall be piped in parallel. All piping downstream of these filters shall be brass. The headers back of each board shail be brass pipe with 1/4" fitting brazed to the pipe for individual instrument air supply.

4. Air supply piping to locally mounted instruments, small auxiliary panels, and panels with less than ten air pilot users shall conform to the piping specification, and each shall be fitted with an individual combination air supply regulator and filter. 
ENG STO 6OA

PAGE $\quad 36$

REVISION 0

INSTRUMENTATION

FOSTER

ad

WHEELER

DATE May 1, 1978

PROCESS PLANTS DIVISION

\section{S. Accessibility}

1. Connections shall be located for maximlom convenience in operating and servicing the instruments. The following general rules shall be adhered to, unless limited by other requirements in the design of the unit:

a. Connections shall be oriented so that instruments or piping will not obstruct aisles or platforms.

b. Control valves shall be accessible from the ground, platforms, or permanent ladders. Clearance shall be allowed between the top of the diaphragm and the underside of the nearest obstruction above it for the removal of the diaphragm. Special clearance shall not be provided for removal of valve trin. Clearances for handwheel operators and valve positioners shall be considered in accordance with the valve vendor's drawing (see ENG STD 50A1).

c. Primary measuring elements for instruments operating in conjunction with control valves shall be located so that the instrument can be mounted close to the control valve without excessive length of meter leads. Local instruments operating In conjunction with control valves shall be located, when feasible, so that they are visible from the control valves. When not feastble, a receiver gauge shall be mounted visible from the control valve.

d. Connections for local pressure gauges, dial thermometers, and test wells shall be located so that gauges will be at a visible level and test points will be readily accessibie.

e. Orifice for pedestal mounted flow meters (except in air or gas service or underground lines) shall be located at a minimum elevation of 7 feet (2135 ma) above grade or platform to allow the meter leads to slope to the instruments.

f. Orifices and line mounted flow transmitters, as well as thermocouples, which are located less than 22 feet (6705 mm) above grade shall be accessible from portable ladders. Above 22 feet $(6705 \mathrm{~mm})$ they shall be accessible from walkways, ladders, platforms, and/or portable platforms.

8. Clearance shall be provided at orifices for valves, pots, or instruments which may be located at the line.

h. Connections on vessels for gauge glasses and level instruments shall be oriented to minimize the effect of inlet and outlet streams on the instruments. 


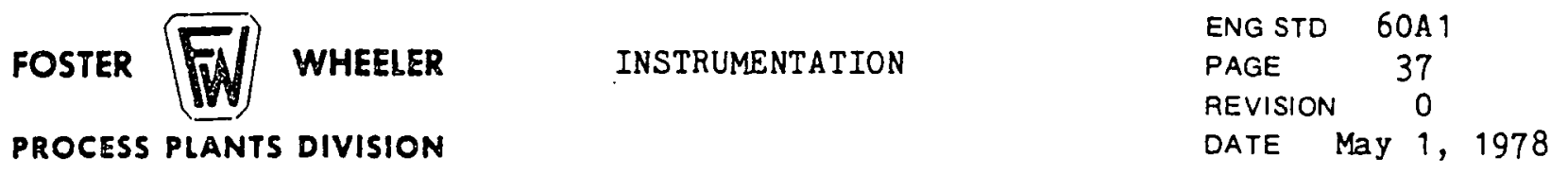

j. Gauge glasses and level instruments shall be adjacently located and, if possible, the gauge glass shall be visible from any valve which controls the level in the vessel.

k. All instruments requiring adjustment shall be accessible for servicing from grade, walkways, ladders, or platforms. Accessibility from the ground shall be from a portable ladder. In addition, transmitters may also be accessible from portable platforms. 


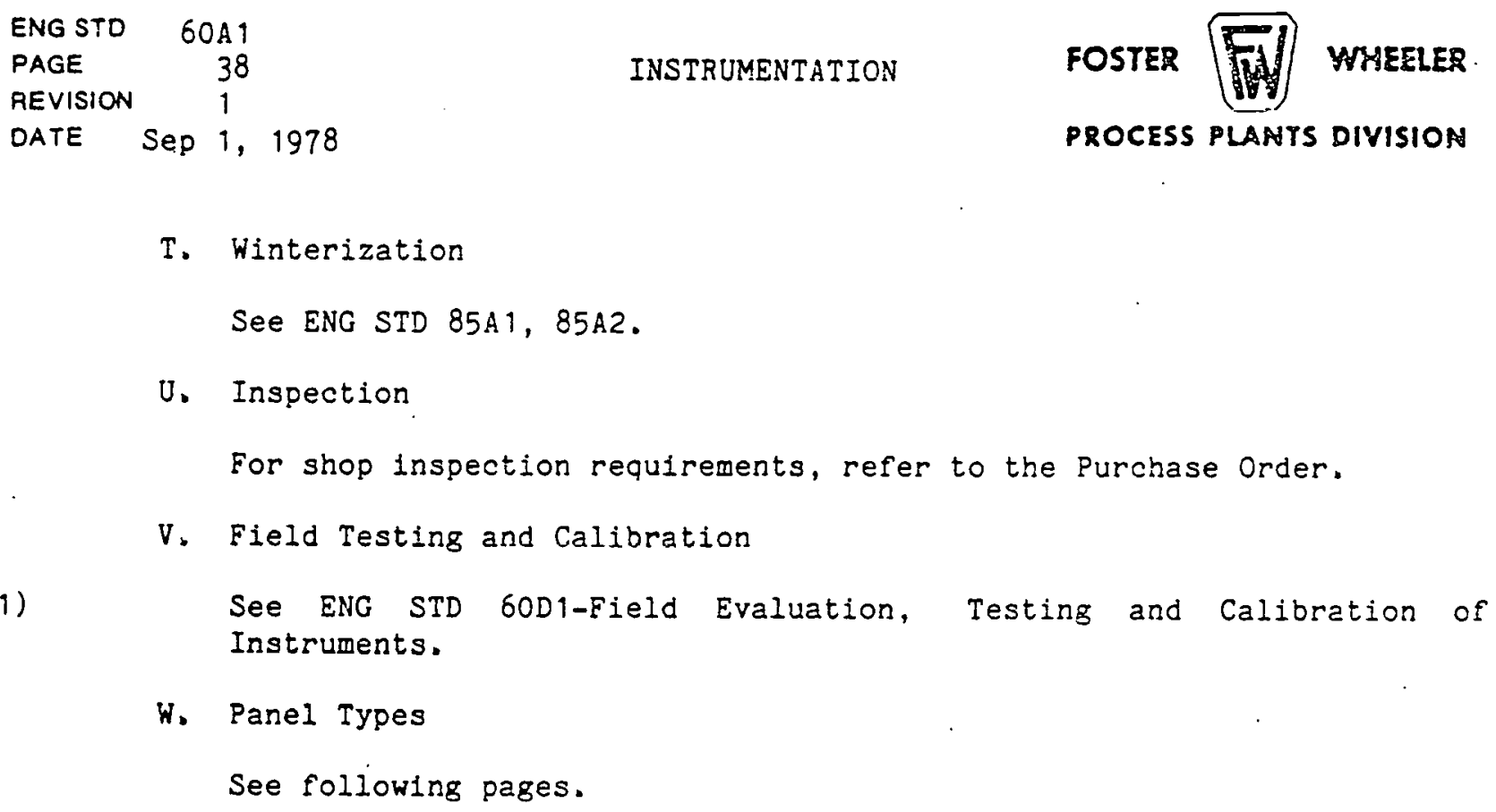

T. Winterization

See ENG STD 85A1, 85A2.

U. Inspection

For shop inspection requirements, refer to the Purchase Order.

V. Field Testing and Calibration

See ENG STD 60D1-Field Evaluation, Testing and Calibration of Instruments.

W. Panel Types

See following pages.

(1) 
FOSTER FH WHELER INSTRUMENTATION

PROCESS PLANTS DIVISION

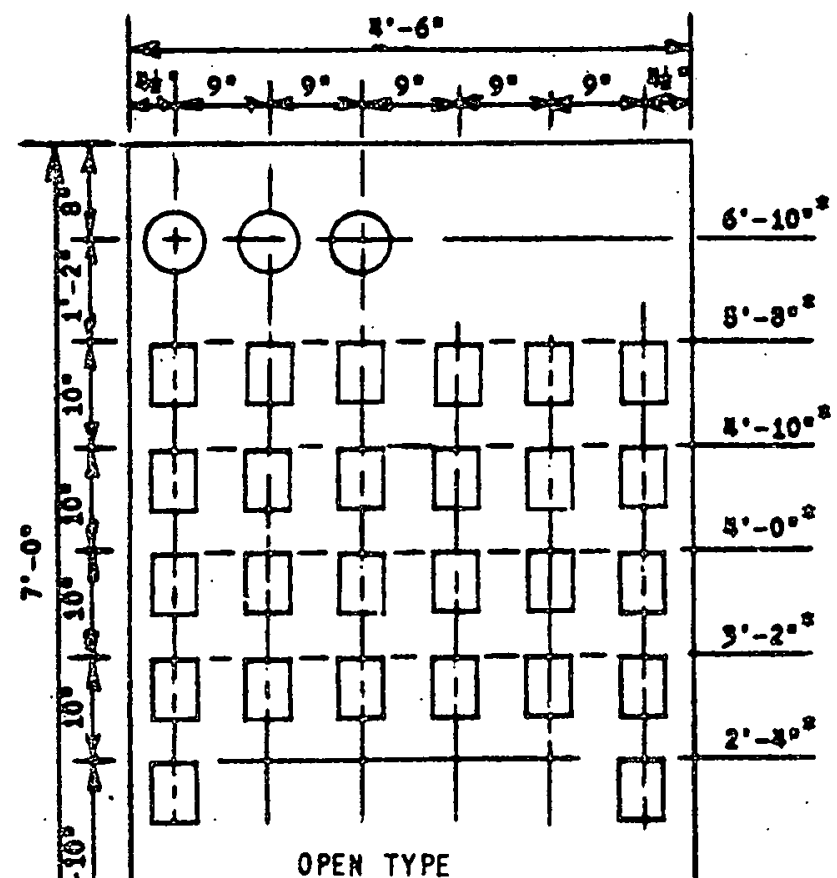

ENG STD $60 A 1$

PAGE $\quad 39$

REVISION 0

DATE May 1, 1978

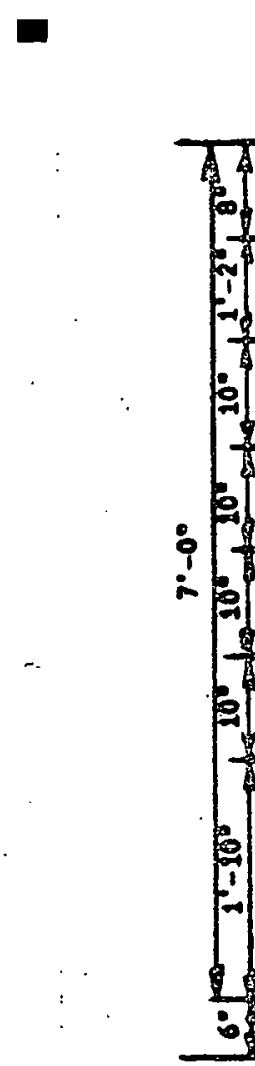

MAX. 16ST. DEHSITT 4.78/LIH. FT. OISTAGCE FEOH FLOOR * $6^{\circ} \times 6^{\circ}$ 1HST. CUT-OUTS

Cy98

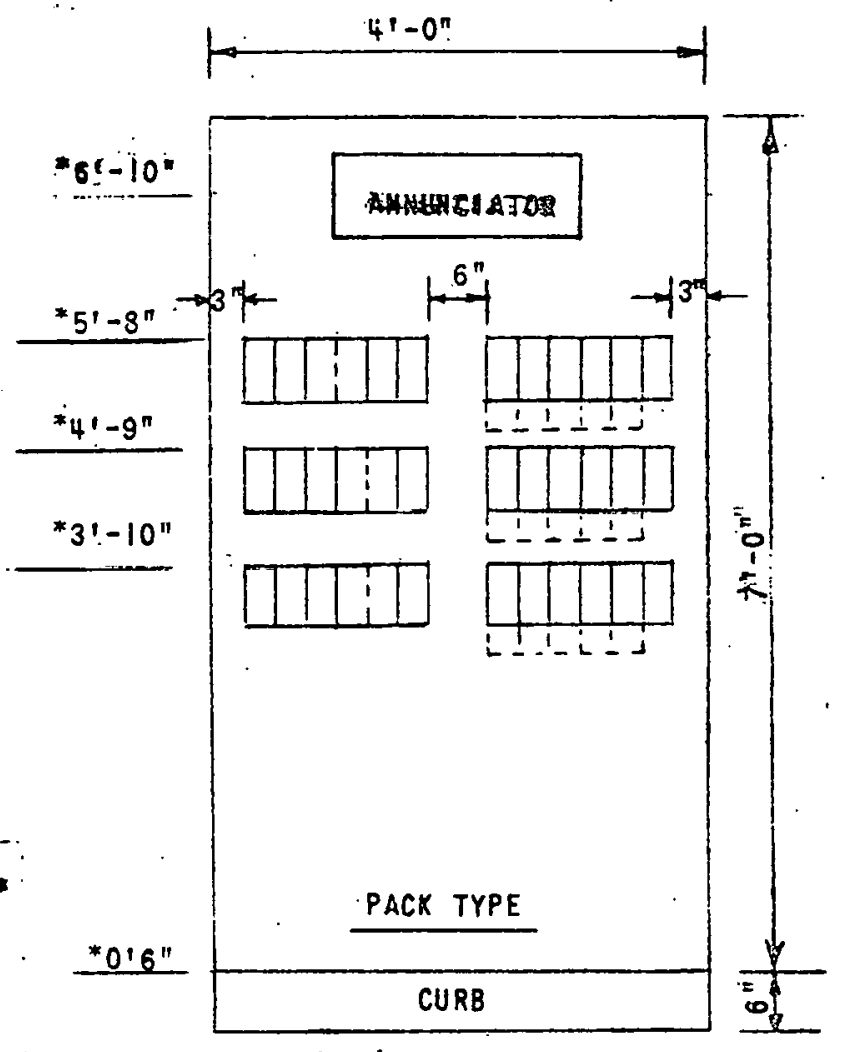

TYPE "A" - CONVENTIONAL - MINIATURE INSTRUMENTS

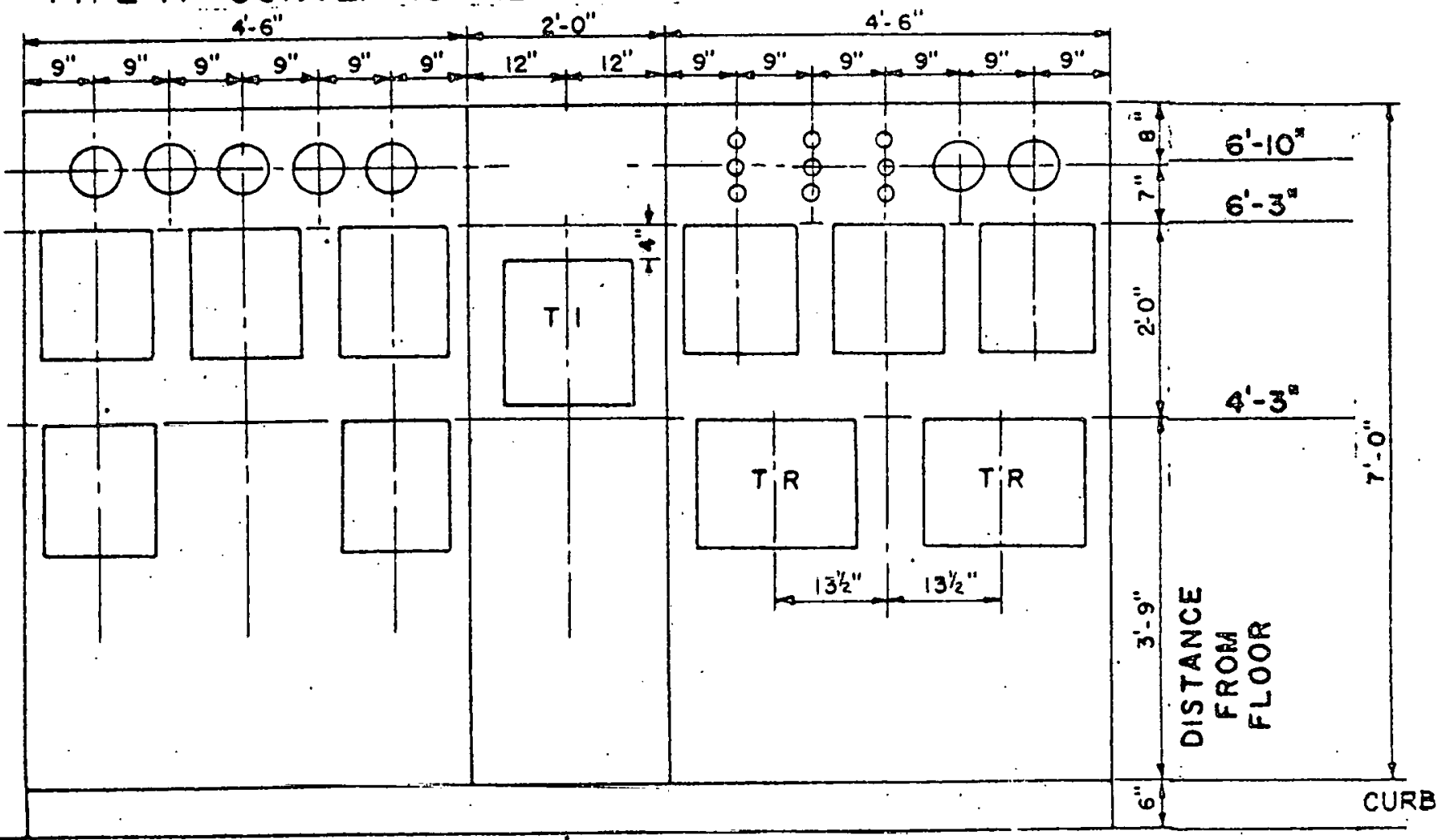

TYPE "B"- CONVENTIONAL - LARGE CASE INSTRUIMENTS

NOTE: LOCATIOH OP 2:0" SECTION IN PANEL a ARANGEMENTS IS OPTIOAAL WHEN AOJACENT PANEL IS TYPE "C": ADD 6 "TO HEIGHT OF PANEL ON TAP. 
ENG STD 60A 1

PAGE 40

REVISION 0

INSTRUMENTATION

FOSTER WHEELER

DATE May 1, 1978

PROCESS PLANTS DIVISION

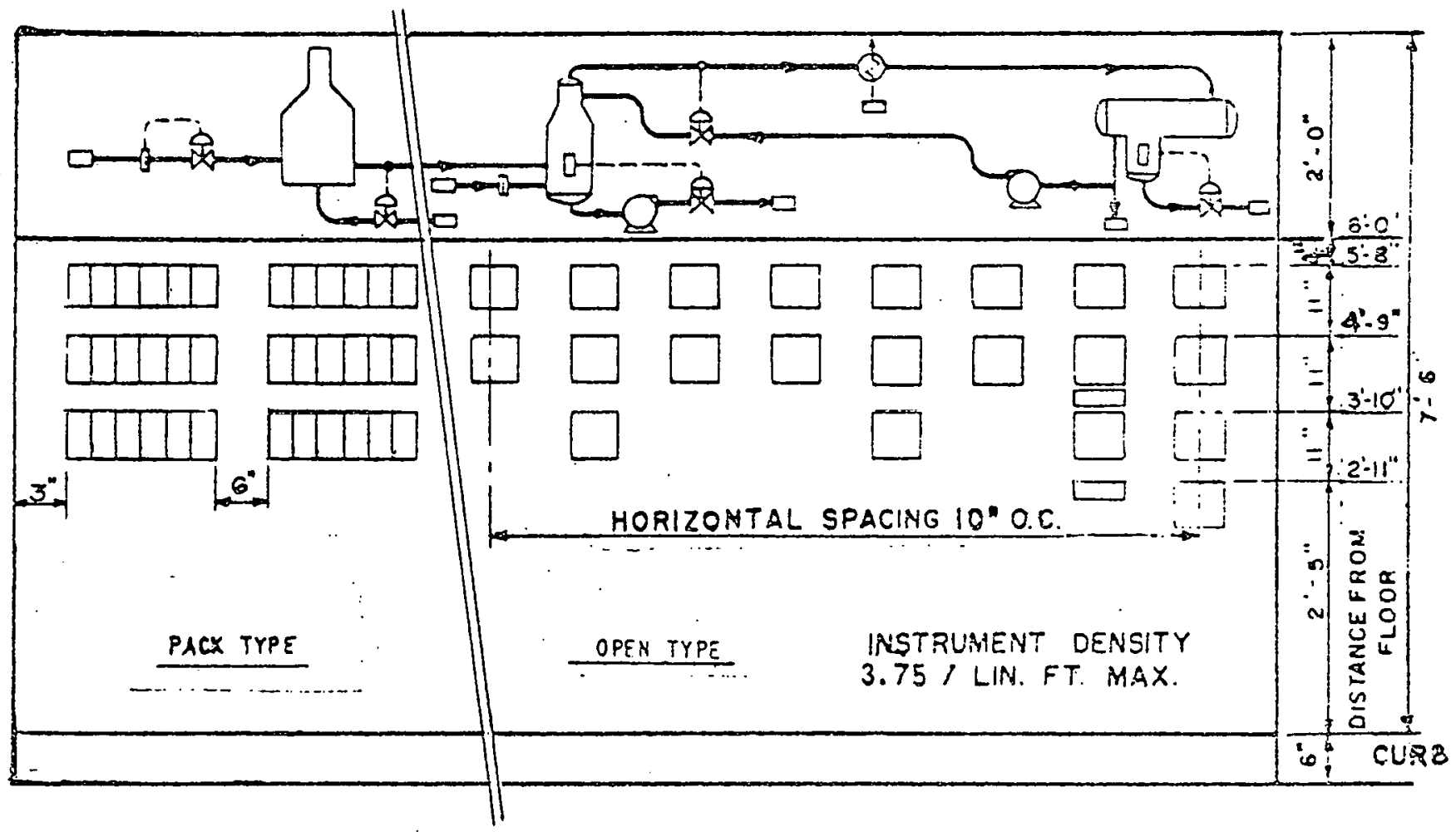

TYPE "C" - SEMI-GRAPHIC

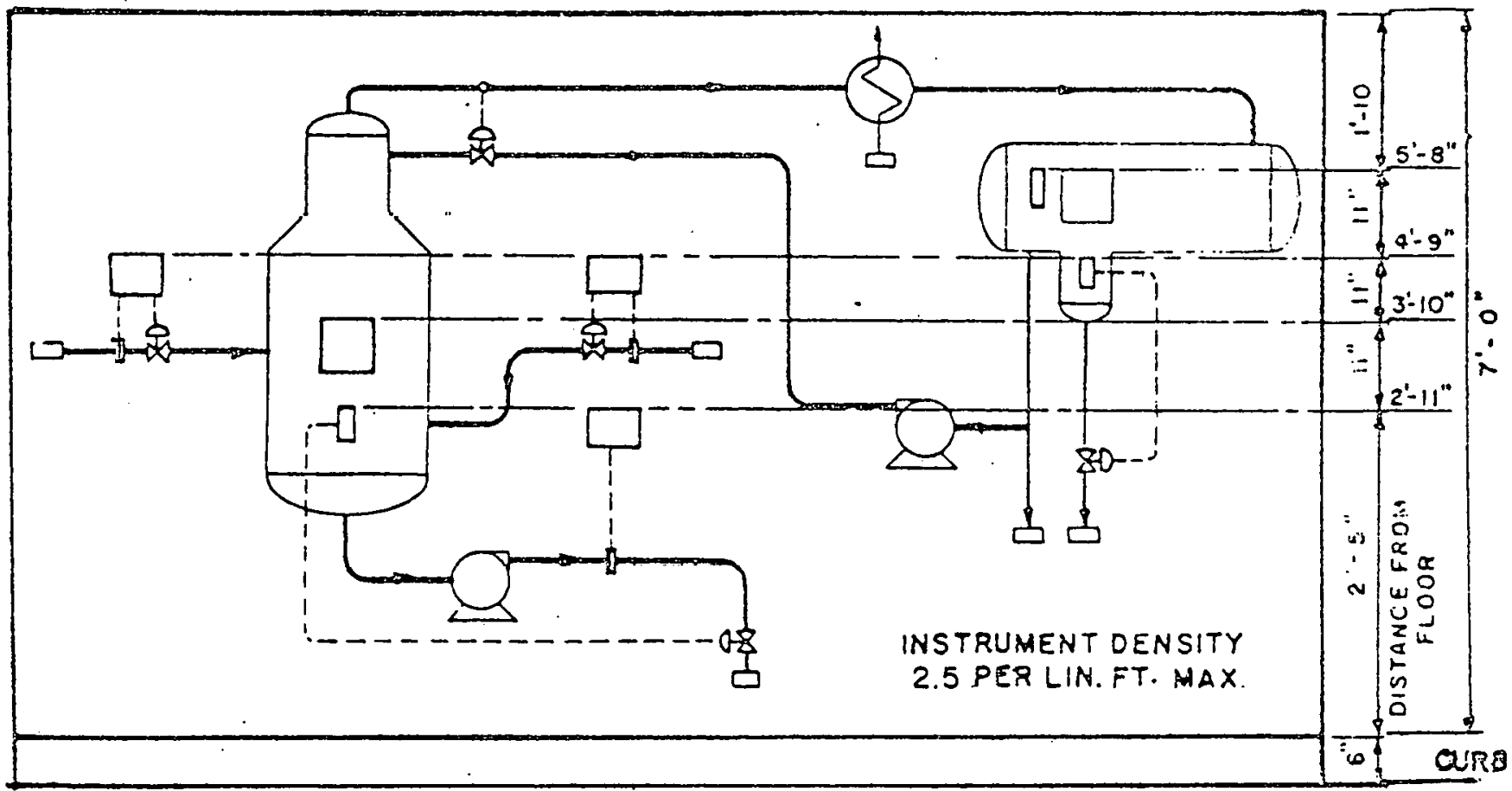

TYPE "D" - FULL GRAPYIC 
FOSTER WHEELER

PROCESS PLANTS DIVISION
INSTRUMENTATION

ENG STD

PAGE

$60 \mathrm{~A} 1$

REVISION 0

DATE May 1, 1978
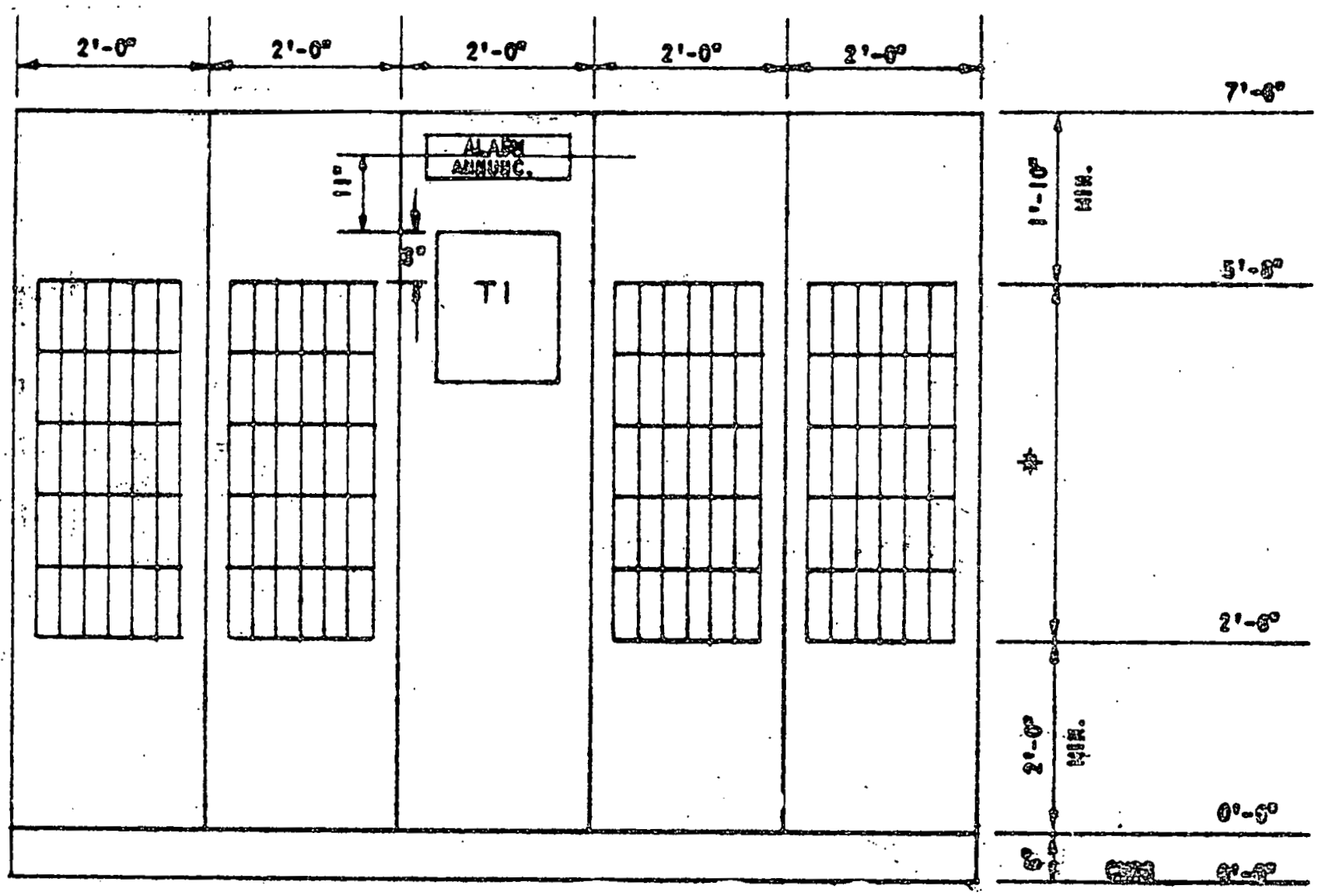

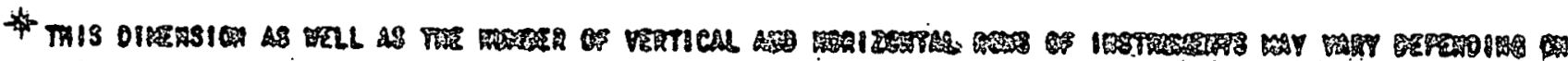

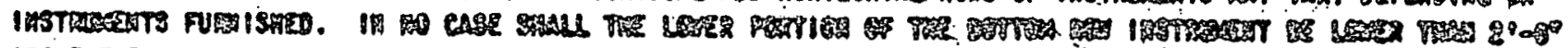

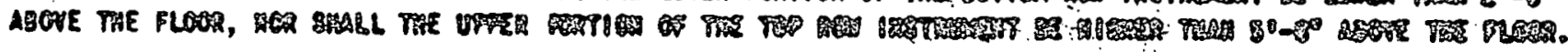


ENG STO 6OA 1

PAGE 42

REVISION 0

INSTRUMENTATION

DATE May 1, 1978

FOSTER WHEELER

PROCESS PLANTS DIVISION

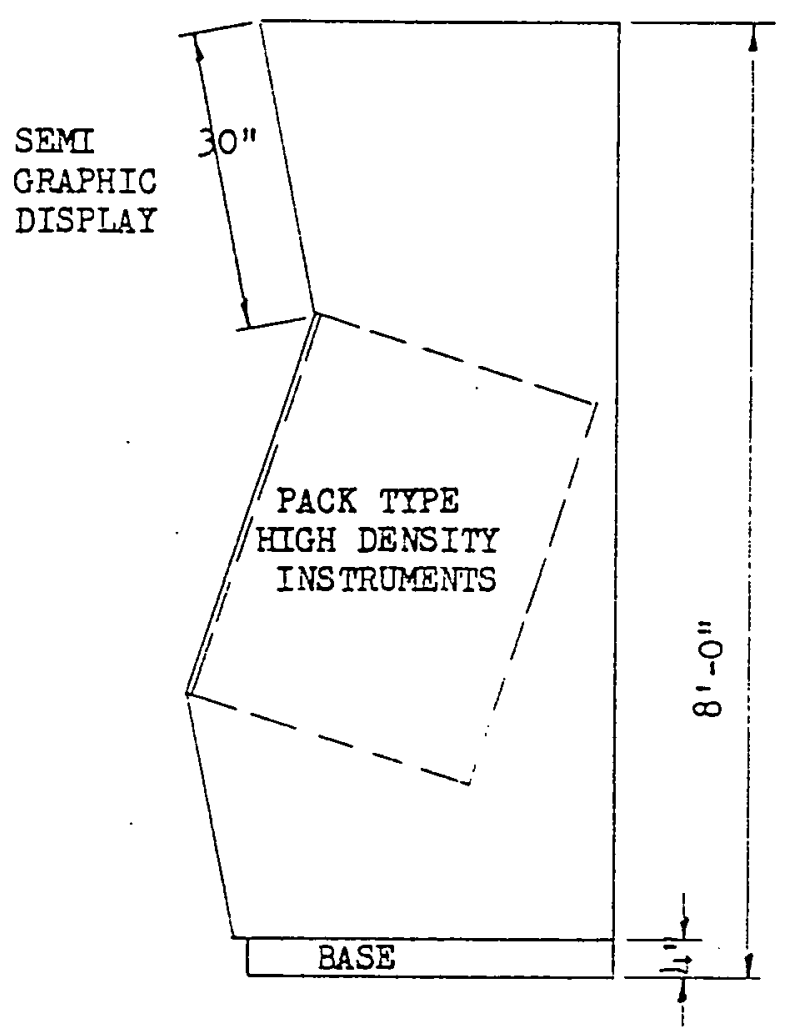

"Z" DESIGN

TYPE F

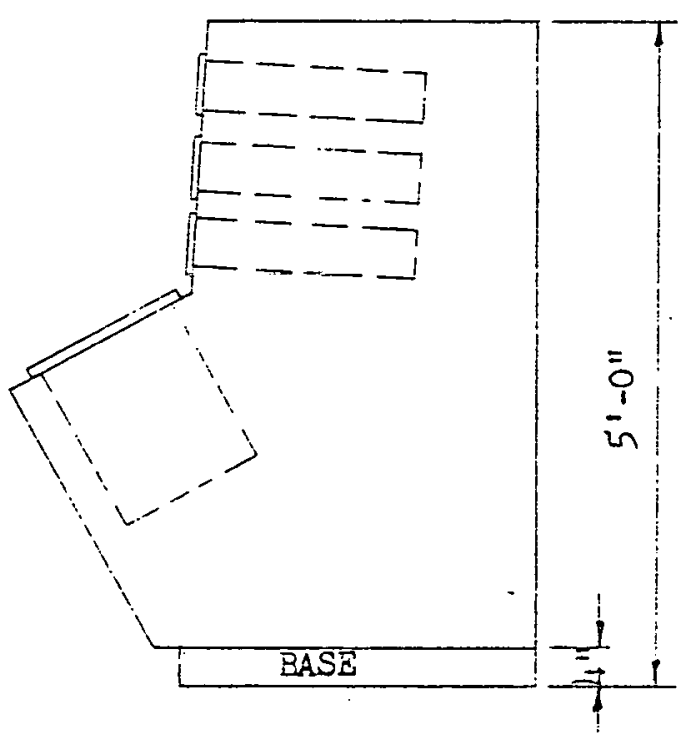

CONSOIE DESICN

TIPE G 
FOSTER FI WHEELER

PROCESS PLANTS DIVISION
ENG STD $60 \mathrm{~A} 1$

PAGE 43

REVISION 0

DATE May 1, 1978

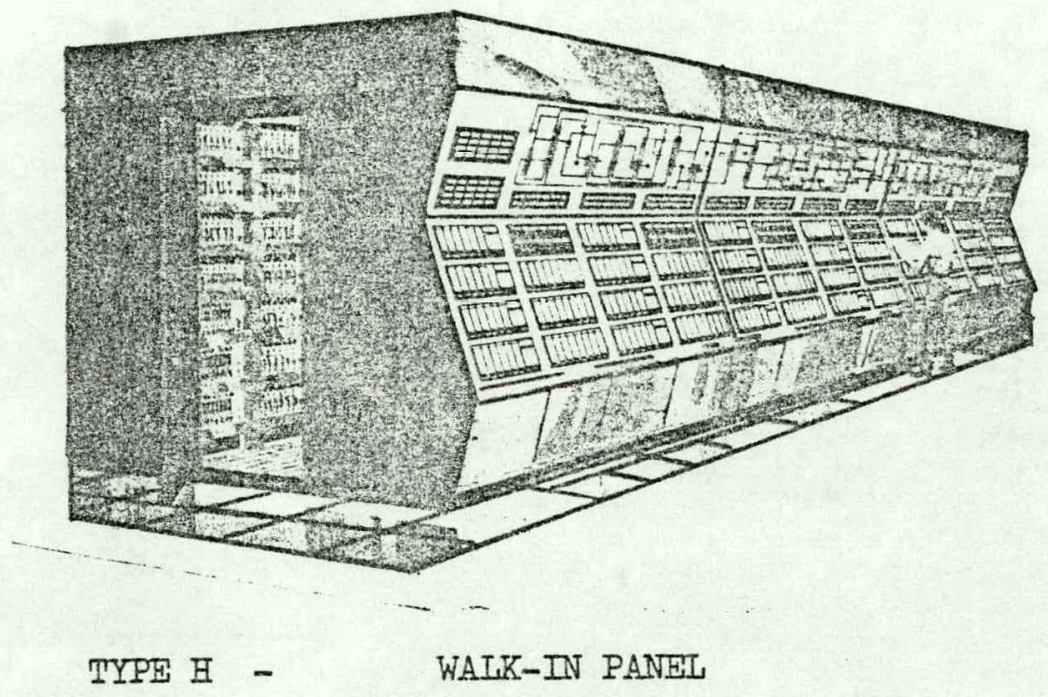

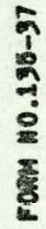

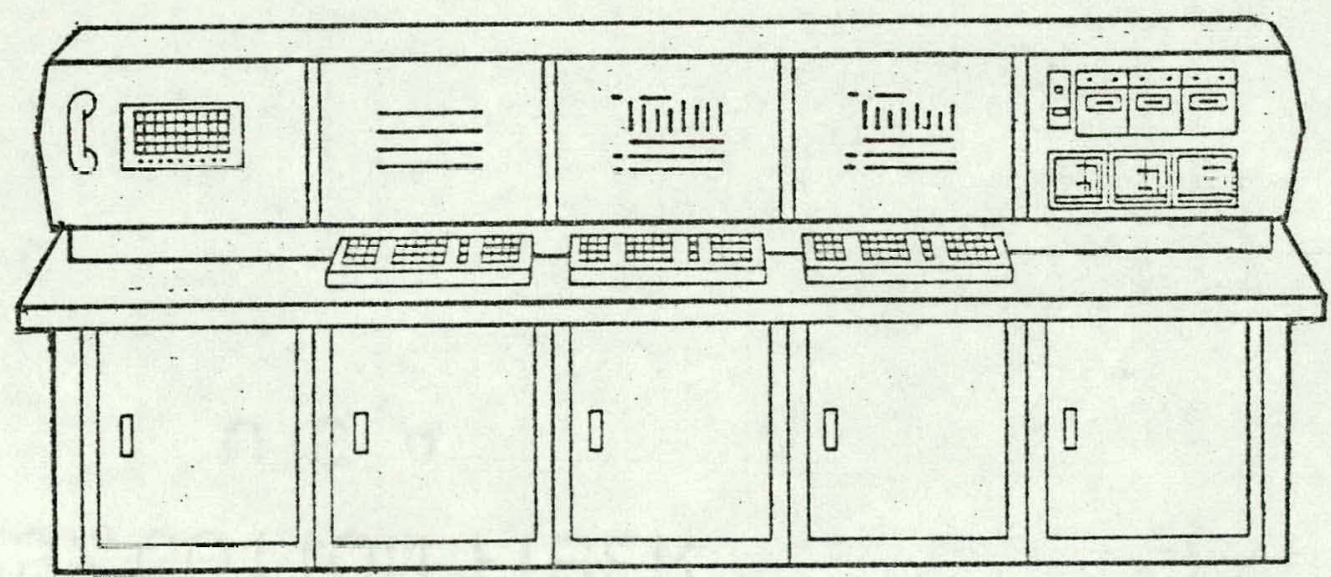

TYPE J - OPERATOR CONSOLE WITH CRT DISPLAYS 
ENG STD $60 \mathrm{~A} 1$

PAGE 44

REVISION 1

DATE Sep 1, 1978

INSTRUMENTATION

FOSTER

WU WIEELER

PROCESS PLANTS DIVISION

\section{REFERENCES}

Latest editions or revisions of the following documents are referred to in this standard:

A. Foster wheeler Standards

1. ENG STD 47A2, Standard Building Specification, Control house, Concrete Block Wall, Flat Roof

2. ENG STD 47A3, Standard Building Specification, Control House, Concrete Block Halls, Peaked or Sloped Roof

3. ENG STD 50A1, Piping

4. ENG STD 50B16.1 through 508.16.3 Piping Reference Standards, Control Valve Arrangement

5. ENG STD 60A2, Instrumentation, Electronic Wiring Standard

6. ENG STD 60A3, Instrumentation, Symbols and Identification

7. ENG STD 6OD1, Field Inspection, Testing and Calibration of Instruments.

8. ENG STD 64A1, Standard Specification for Shop Fabricated Piped and Wired Instrument Panel Board

9. ENG STD 65811.1 through 65811.10, Instrument Piping Standards, Thermocouple Wells

10. ENG STD 65B12.1 through 65Bi2.65, Instrument Piping standards, Flow Meter Installations

11. ENG STD 65B13.1 through 65B13.6, Instrument Piping Standards, Orifice Installation

12. ENG STD 65B14.1 through 65814.40, Instrument Piping Standards, Piping at Level Instruments

13. ENG STD 65B15.1 through 65B15.51, Instrument Piping Standards, Pressure Instrument Connections

14. ENG STD 68B11.1 through 68B11.14, Support and Rack Standards

15. ENG STD 7OA1, Electrical Standard

16. ENG STD $85 \mathrm{~A} 1$, Winterizing Ambient Temperature above 32 ₹ 


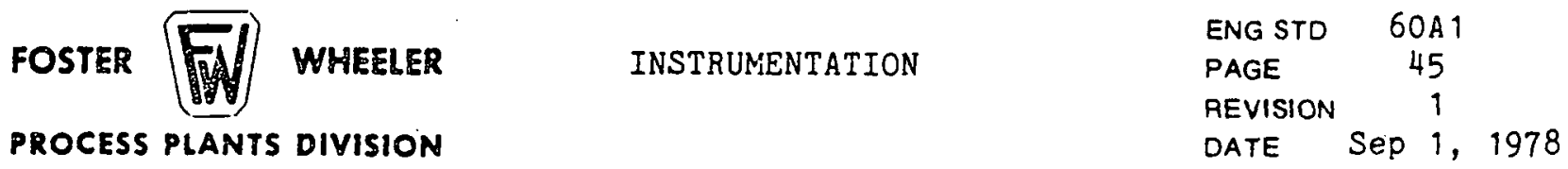

17. ENG STD 85A2, Winterizing, Ambient Design Temperature from $15 \mathrm{~F}$ to $32 \mathrm{~F}$

18. ENG STD 85F1, Winter Design Temperature

B. American National Standards Institute

1. ANSI C85.1 and C85.1a, Terminology for Automatic Control

2. ANSI C96.1 Temperature Measurement Thermocouples

3. ANSI B16.1 Cast Iron Pipe Flanges and Flanged Fittings

4. ANSI B 16.5 Steel Pipe Flanges, Flanged Valves and Fittings

C. American Petroleum Institute

1. API RP 520, Part I and Part II, Recommended Practice for the Design and Installation of Pressure-Relieving Systems in Refineries

2. API STD 526, Flanged Steel Safety Relief Valves

3. API STD 527, Commercial Seat Tightness of Safety Relief Valves with Metal-to-Metal Seats

4. API STD 2000, Venting Atmospheric and Low-Pressure Storage Tarks

D. American Gas Association

1. Gas Measurement Committee Report No. 3, Orifice Metering of Natural Gas

E. ASME Boiler and Pressure Vessel Code

1. ASME Power and Rniler Codc

a. Section I, Power Boilers

b. Section VIII, Division 1, Pressure Vessels

2. ASME Power Test Code 19.5

F. Instrument Society of America

1. ISA RP 4.1, Uniform Fare to Face Dimensions for Flanged Control Valve Bodies

2. ISA STD S5.1, Instrumentation Symbols and Identification 
ENG STO 60A 1 ;

PAGE $\quad 46$

INSTRUMENTATION

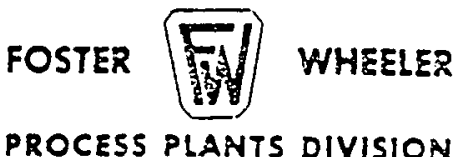

DATE May 1, 1978

PROCESS PLANTS DIVISION

3. ISA STD S12.4, Instrument Purging for Reduction of hazardous Area Classification

G. National Electrical Code

H. L. K. Spink: Principles and Practice of Flow Metering Engineering

J. NFPA National Fire Codes

1. No. 493 Intrinsically Safe Control Equipment

2. No. 496 Purged Enclosures for Electrical Equipment 


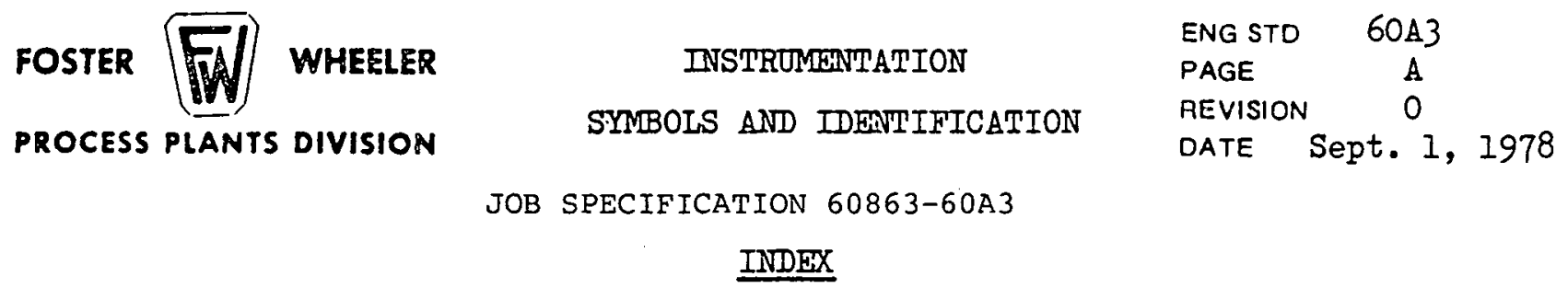

Page

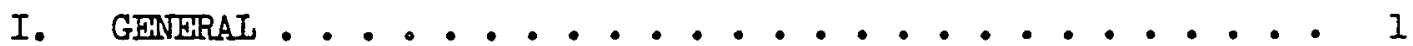

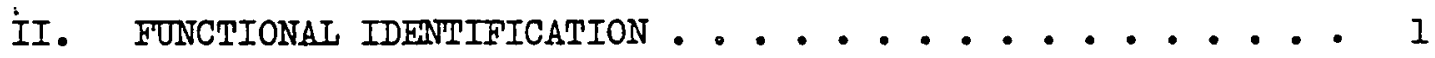

Table I - Meanings of Identification Letters. ...... 2

Table 2 - Functional Identifications. .........

Table 3 - Designations for Relays and Computer Functions. .

III. IOOP IDENTIFICATION ............... 6

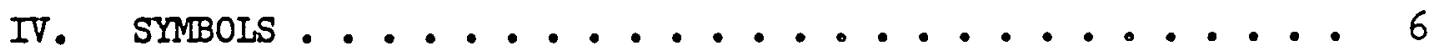

NOTE: The instrument numbering system is based on "Data Acquisition and analysis - Guidelines for 1PH Demonstration Projects" issued by S.E.R.I. March 30, 1979. 


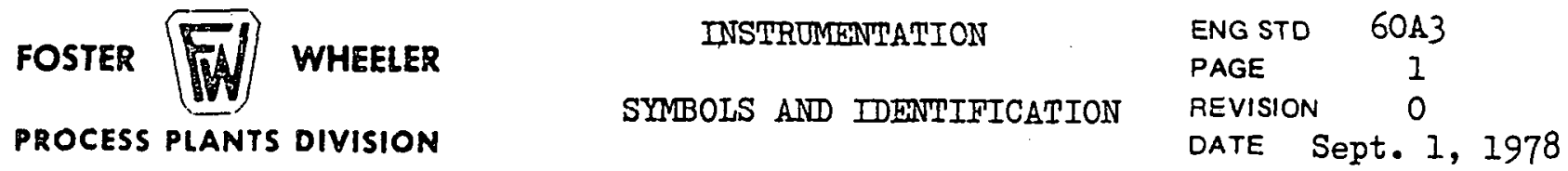

I. GENERAL

A. Instruments shall be identified by a system of letters and numbers generally in accordance with the Instrument Society of America Standard S5.1, extracts from which follow. Minor modifications have been made, e.g., pp. 3, 7, 16 and computer symbols.

B. Each instrument will be identified first by a system of letters used to classify it functionally. (See Tables 1 and 2 for the system of letters). To establish a loop identity for the instrument, a number will be appended to the letters. This number will, in general, be common to other instruments of the loop of which this instrument is a part. A suffix is sometimes added to complete the loop identification.

C. Where ISA Standard S5.1 offerg alternate methods of presentation, FWEC practice is to use the method requiring the fewest symbols. Symbols will not be shown for the following:

1. Valve positioners.

2. Field mounted I/P transducers, when no solenoid valve or other device is in Iine between $I / P$ and valve.

3. Balloons identifying control valves (except in the case of split range control valves or where the valve is separated from the rest of the control loop enough to cause confusion).

4. Balloons identifying flow and temperature primary elements.

5. Multiplexing, when used for panel mounted temperature indication only.

6. Irocal process variable indicators on transmitter outputs, unless it is intended to designate a special location for the indicator, as shown by a note next to the tasging balloon,

II. FUNCTIONAL IDENTIBTCATION

A. The functional identification of an instrument will consist of letters from Table 1 , and will include on first-letter, covering the measured or initiating variable, and one or more succeeding letters covering the functions of the individual instrument. Exceptions to this rule are the use of the single letter $L$ to denote a pilot light that is not part of an instrument loop and computer functions which will use modifyingletters only.

B. The succeeding-letters of the functional identification designate one or more readout or passive functions, or output functions, or both. A modifying-letter may be used, if required, in addition to one or more other succeeding-letters. Modifying letters may modify either a firstletter or other succeeding-letters, as applicable. All letters of the functional identification shall be upper case. For examples of combinations of functional identification letters, see Table 2. 


\begin{tabular}{|c|c|c|c|c|c|}
\hline ENG STO & $60 A 3$ & & & 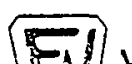 & \\
\hline PAGE & 2 & INSTRUMENTATION & FOSTER & 7.1 & WHEELER \\
\hline REVISION & 0 & & & (18) & \\
\hline DATE & SEPTEMARFR 1.1978 & SYMBOLS AND IDENTIFICATION & PROCESS & PLANTS & DIVISION \\
\hline 11. & UNCTIONAL IDE! & $10 N(\operatorname{cont} d)$ & & & \\
\hline
\end{tabular}

TABLE 1

\begin{tabular}{|c|c|c|c|c|c|}
\hline & \multicolumn{2}{|c|}{ FIRST LETTER } & \multicolumn{3}{|c|}{ SUCCEEDING LETTERS } \\
\hline & $\begin{array}{l}\text { MEASURING OR } \\
\text { INITIATING } \\
\text { VARIABLE }\end{array}$ & MODIFIER & $\begin{array}{l}\text { READOUT OR } \\
\text { PASSIVE } \\
\text { FUNCTION }\end{array}$ & $\begin{array}{l}\text { OUTPUT } \\
\text { FUNCTION }\end{array}$ & MODIFIER \\
\hline$A$ & ANALYSIS 13 ) & & ALARM & & \\
\hline 8 & BUANER FLAME & & USER'S CHOICE (I) & USER'S CHOICE (1) & USER'S CHOICE (1) \\
\hline$i$ & $\begin{array}{l}\text { UONDUCTIVITY } \\
\text { (ELECTAICAL). }\end{array}$ & & & $\begin{array}{l}\text { CONTROL } 16 / \\
\text { CDMPUTERIAUTOIMA }\end{array}$ & . \\
\hline 0 & $\begin{array}{l}\text { DENSITY IMASSI } \\
\text { OR SPECIFIC GRAVITY }\end{array}$ & DIFFERENTIAL & & & \\
\hline 5 & VOLTAGE (EMF) & & PRIMARY ELEMENT & & \\
\hline$F$ & FLOW RATE & RATIO (FRACTION) & & & \\
\hline 6 & GAGING (DIMENSION) & & GLASS & & \\
\hline $\mathrm{H}$ & $\begin{array}{l}\text { HAND (MANUALLY) } \\
\text { INITIATED) }\end{array}$ & & & & $\mathrm{HIGH}$ \\
\hline 1 & CURRENT (ELEC.) & & INDICATE & & \\
\hline$:$ & POWER & SCAN & & MULTIPLEX OR TRENO & \\
\hline$x$ & TIME OA TIME SCHED. & & & $\begin{array}{l}\text { CONTROL STATION } \\
\text { (COMPUTER/MAN (6) }\end{array}$ & \\
\hline$\therefore$ & LEVEL & & LIGHT PILOT (4) & & Low \\
\hline$M$ & $\begin{array}{l}\text { MOISTURE OR } \\
\text { HUMIDITY }\end{array}$ & & & & $\begin{array}{l}\text { MIDDLEOR } \\
\text { INTERMEDIATE }\end{array}$ \\
\hline$\because$ & IJSER'S CHOICE (1) & & USER'S CHOICE & USER'S CHOICE (I) & USER'S CHOICE (i) \\
\hline 0 & USER'S CHOICE (I) & & ORIFICE (RESTRICTI) & & \\
\hline$\circ$ & PRESSUAE OR VACUUM & & $\begin{array}{l}\text { POINT (TEST) } \\
\text { CONNECTION) }\end{array}$ & & \\
\hline 3 & QUANTITY OR EVENT & $\begin{array}{l}\text { INTEGRATE OR } \\
\text { TOTALIZE }\end{array}$ & & & \\
\hline$\therefore$ & PADIOACTIVITY & & RECORO OR PRINT & & \\
\hline 5 & SPEED OR FREQUENCY & SAFETY & & SWITCH & \\
\hline$T$ & TEMPERATURE & . & & TRANSMIT & \\
\hline $\mathrm{U}$ & MULTIVARIABLE & & MULTIFUNCTION & MULTIFUNCTION & MULTIFUNCTION \\
\hline$v$ & VISCOSITY & & & $\begin{array}{l}\text { VALVE.DAMPER. } \\
\text { OR LOUVER }\end{array}$ & \\
\hline$w$ & WEIGHT OR FORCE & & WELL & & \\
\hline$x$ & UNCLASSIFIED (2) & & UNCLASSIFIED (2) & UNCLASSIFIED (2) & UNCLASSIFIED (2) \\
\hline$Y$ & UEEA'S CHOICE (1) & & & REI.AY OR COMPUTE & \\
\hline$z$ & POSITION & & & $\begin{array}{l}\text { ORIVE,ACTUATE OR } \\
\text { UNCLASSIFED FINAL } \\
\text { CONTROL ELEMENT }\end{array}$ & \\
\hline
\end{tabular}


FOSTER WH WHELER

PROCESS PLANTS DIVISION
INSTRUMIINTATION

SYMBOIS AND IDENTIFICATION
ENG STD

PAGE

60A3

REVISION 0

DATE Sept. 1, 1978

\section{FUNCTIONAL TDENTIFICATION (contd)}

\section{Notes For Table 1-- Meanings of Identification Letters}

1. A user's choice letter is intended to cover unlisted meanings that will be used repetitively in a particular project. If used, the letter may have one meaning as a first-letter and another meaning as a succeeding-letter. The meanings need be defined only once in a legend, or otherwise, for that project. For example, the letter $\mathbb{N}$ may be defined as modulus of elasticity as a first-letter and oscilloscope as a succeeding-letter.

2. The unclassified letter $X$ is intended to cover unlisted meanings that will be used only once or to a limited extent. If used, the letter may have any number of meanings as a first-letter and may have any number of meanings as a succeeding-letter. Except for its use with distinctive symbols, it is expected that the meanings will be defined outside a tagging balloon on a flow diagram. For example, XR-2 may be a stress recorder, XR-3 may be a vibration recorder, and $X X-4$ may be a stress oscilloscope.

3. First-letter A for analysis covers all analyses that are not listed in Table 1 and are not covered by a user's choice letter. It is expected that the type of analysis in each instance will be defined outside a tagging balloon on a flow diagram.

4. A pilot light that is part of an instrument loop shall be designated by a first-letter followed by succeeding-letter I. For example, a pilot light that indicates an expired time period may by tagged $\mathrm{KL}$. However, if it is desired to tag a pilot light that is not part of a formal instrument loop, the pilot light may be designated in the same way or alternatively by a single letter $\mathrm{L}$. For example, a running light for an electric motor may be tagged either EL, assuming that voltage is the appropriate measured variable, or XI, assuming that the light is actuated by auxiliary electric contacts of the motor starter, or simply $\mathrm{L}$.

5. If a given loop has more than one instrument with the same functional identification, then a suffix shall be appended to the loop number, e.g. FV-2A, FV-2B, etc., or TE-25-1, TE-25-2, etc. However, if a computer or Data Logger is involved, the use of suffixes may not be compatible and unique consecutive numbers shall be used. The main instrument should take the number of the Primary Case, e.g. With High and Iow Flow arrangement, the transmitters shall be numbered, say FT-2 and FT-3, whereas the main instrument would be numbered FRC-2.

6. When a digital control system is being used, the type of analog backup used can be distinguished by using output functions $\mathrm{C}$ or $\mathrm{K}$. 


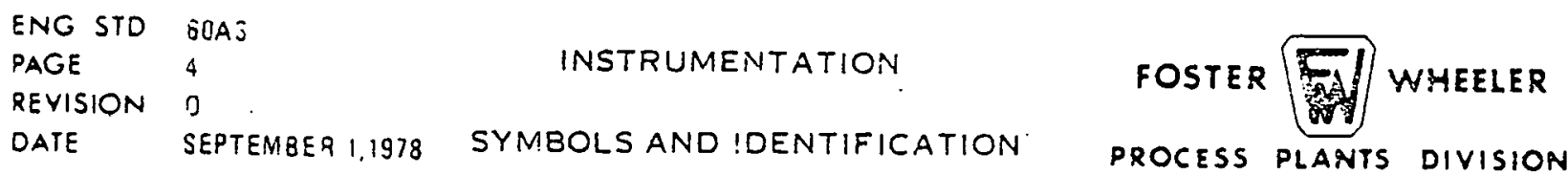

11. FUNCTIONAL IDENTIFICATION (con't)

TABLE 2

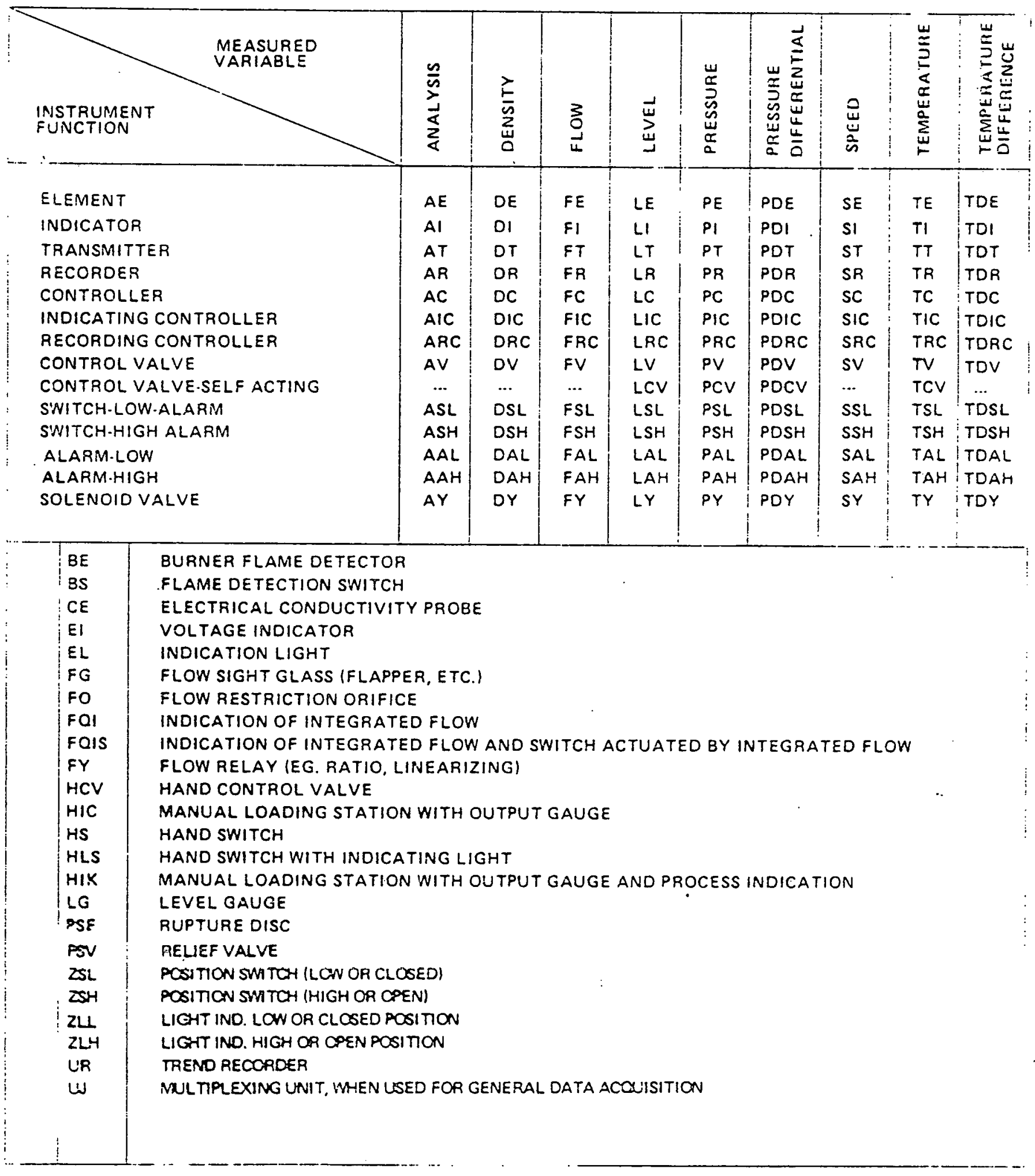




FOSTER WHEELER
PROCESS PLANTS DIVISION

11. FUNCTIONAL IDENTIFICATION (cont'd)

TABLE 3

\section{DESIGNATIONS FOR RELAYS}

AND COMPUTER FUNCTIONS

THE FUNCTION DESIGNATIONS ASSOCIATED WITH RELAYS AND COMPUTERS MAY BE USED AS FOLLOWS, INDIVIDUALLY OR IN COMBINATION. THE USE OF A BOX ENCLOSING A SYMBOL IS REQUIRED; THE BOX IS INTENDED TO AVOID CONFUSION BY SETTING OFF THE SYMBOL FROM OTHER MARKINGS ON A DIAGRAM.

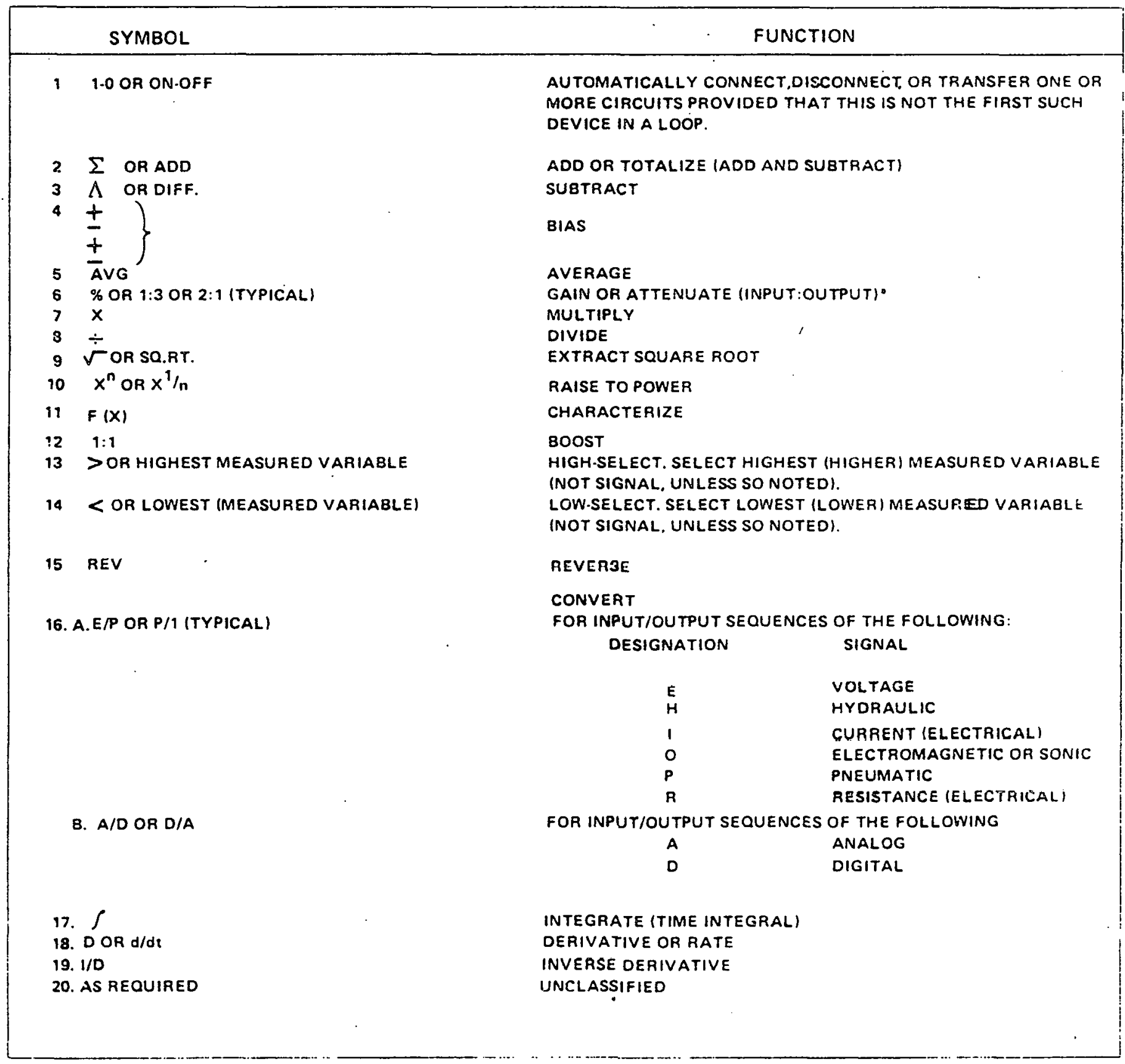


$\begin{array}{lc}\text { ENG STD } & 60 \mathrm{~A} 3 \\ \text { PAGE } & 6\end{array}$

REVISION 0

DATE Sept. I, 1978
INSTROMENTATION

SIMBOIS IND IDENTIFICATION
FOSTER

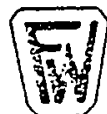

WHEELER

PRCCESS PLANTS DIVISION

\section{IOOP IDENTIFICATION}

A. The loop identification of an instrument will generally use a number assigned to the loop of wich the instrument is a part. Each instrument loop shall have a unique number. An instrument common to two or more loops may have a separate loop number, if desired.

B. A single sequence of loop numbers shall be used for all instrument loops of a contract regardless of the first letter of the functional identification of the loops. The loop numbering sequence will begin with the number 1 and run consecutively until all loops in a given contract are identified.

C. It is Foster wheeler practice to assign a new contract number to each section of a multi-section job. Therefore, to discriminate between such sections, the functional identification letters may be preceeded by the last one or two digits of the contract number. Or, if process area numbers are assigred, they may be used as a prefix to discriminate between loop numbering in different process areas.

TV. SYMBOLS

A. It is not the intention of this standard to list all symbols or combinations. ISA Standard S5.I lists many more.

B. Control valve positioners and control valve electric-to-air converters will not be shown. Therefore, with an electrical system, the controller output (electrical) signal will be schematically shown connected to the valve diaphragm, the actual installation will have a converter.

C. In addition, various expedients may be used on individual contracts. For examole, the letter "V" just outside the circle can indicate an item supplied by a packase vendor, or the letters "IP" can indicate a local panel mounting.

D. The actuator action in the event of actuating medium failure shall be shown on control valves (see control valve symbols on page 9).

E. Also, when dual pen instruments are shown on different flow diagrams, a note can show "To second pen on TR-10I" or the tangential circle can be shown in phantom as follows: 


\begin{tabular}{llll} 
FOSTER WHEELER & \multicolumn{1}{l}{ INSTRUMENTATION } & ENG STD & 6003 \\
& & PAGE & 7 \\
PROCESS PLANTS DIVISION & SYMBOLS AND IDENTIFICATION & REVISION & 0 \\
DATE & SEPTEIMBER 1,1978
\end{tabular}

IV. SYMBOLS (con't)

E (conted)

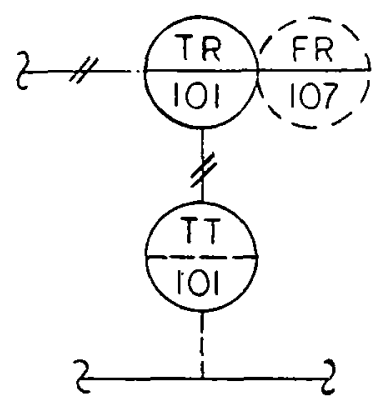

P/I DIAGRAM N0.1

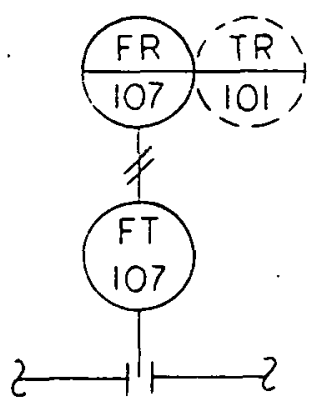

P/I DIAGRAM NO.2

F COMPUTER FUNCTIONS WILLL BE SHOWN AS A HEXAGON. USE MODIFYING LETTERS ONLY SINCE THE MEASURED VARIABLE "UJ" IS IMPLIED BY THE HEXAGON.

G THE SYMBOLS USED TO DEPICT INSTRUMENTATION ON FLOW DIAGRAMS AND OTHER DRAWINGS ARE SHOWN BEL OW;

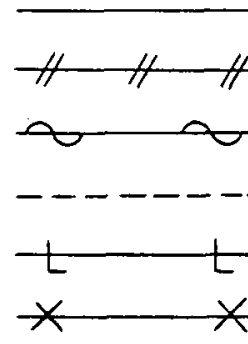

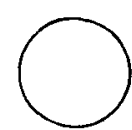
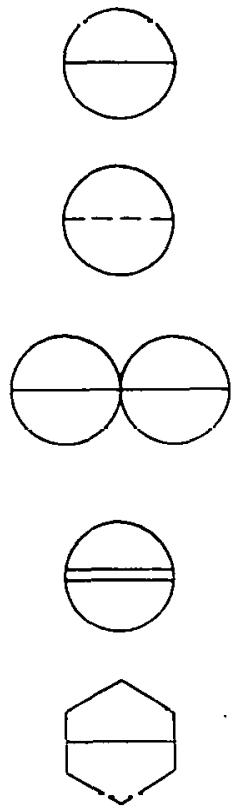

CONNECTION TO PROCESS

PNEUMATIC SIGNAL

ELECTROMAGNETIC (NUCLEAR) OR SONIC SIGNAL

ELECTRICAL SIGNAL

HYDRAULIC SIGNAL

CAPILLARY TUBING (FILLED SYSTEM)

LOCALLY MOUNTED

MOUNTED ON BOARD

MOUNTED BEHIND THE BOARD OR OTHER CONTROL ROOM LOCATION

INSTRUMENT FOR TWO MEASURED VARIARI, F (BOAAD MOUNTED)

LOCAL PANEL BOARD MOUNTED

COMPUTER FUNCTION (IN CONTROL ROOM BUT NOT NECESSARILY BOARD MOUNTEDI 
ENG STD DOA3

PAGE $\quad$ S

REVISION 0

DATE SEPTENHER $\mathrm{i}, \mathrm{i} 978$

IV. SYMBOLS (con't)
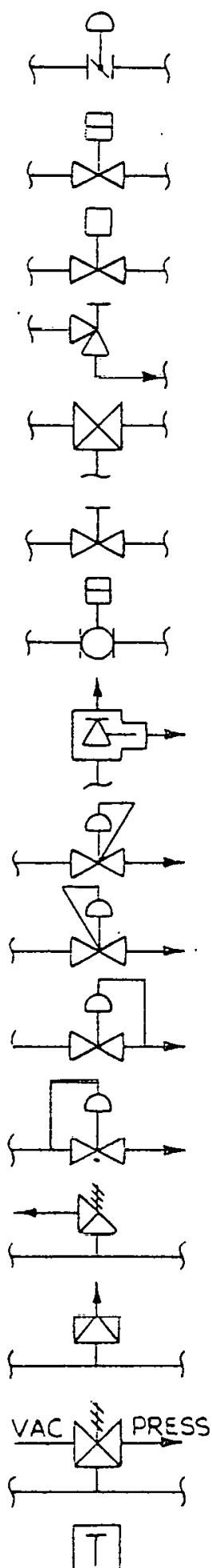

INSTRUMENTATION FOSTER WHELLR
SYMIBOLS A"M IOENTIFICATION PROCESS PLANTS DIVISION

DIAPHRAGM OPERATED BUTTERFLY. DAMPER OR LOUVER

CYLINDER OPERATED VALVE

SOLENOID OPERATED VALVE

ANGLE VALVE

3.WAY VALVE BODY

HAND CONTROL VALVE

BALL OR ROTARY PLUG VALVE

AUTOMATIC RECIRCULATION CONTROL V.ALVE

PRESSURE REDUCING VALVE.SELF.CONTAINED (REGULATOR)

BACKPRESSURE VALVE.SELF CONTAINED (REGULATOR)

PRESSURE REDUCING VALVE WITH EXTERNAL PRESSURE TAP

BACKPRESSURE VALVE WITH EXTERNAL PRESSURE TAP

SAFETY VALVE (RELIEF)

RUPTURE DISC.

PRESSURE \& VACUUM RELIEF VALVE

TRAPS 


\begin{tabular}{|c|c|c|c|c|c|}
\hline FOSTER & $($ ind & WHEELER & INSTRUMENTATION & $\begin{array}{l}\text { ENG STD } \\
\text { PAGE }\end{array}$ & $\begin{array}{l}60 A 3 \\
9\end{array}$ \\
\hline PROCESS & PLANTS & DIVISION & SYMBOLS AND IDENTIFICATION & $\begin{array}{l}\text { REVISION } \\
\text { DATE }\end{array}$ & $\begin{array}{l}0 \\
\text { SEPTEMBER } 1,19 ? 8\end{array}$ \\
\hline
\end{tabular}

IV. SYMBOLS (con't)

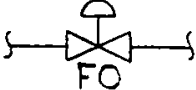<smiles>CC(=O)C1(C(F)(F)F)CCCCC1</smiles>

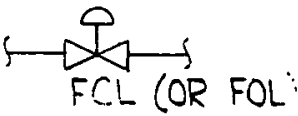

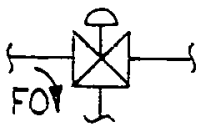

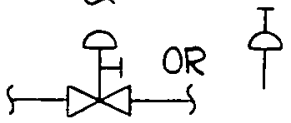

n
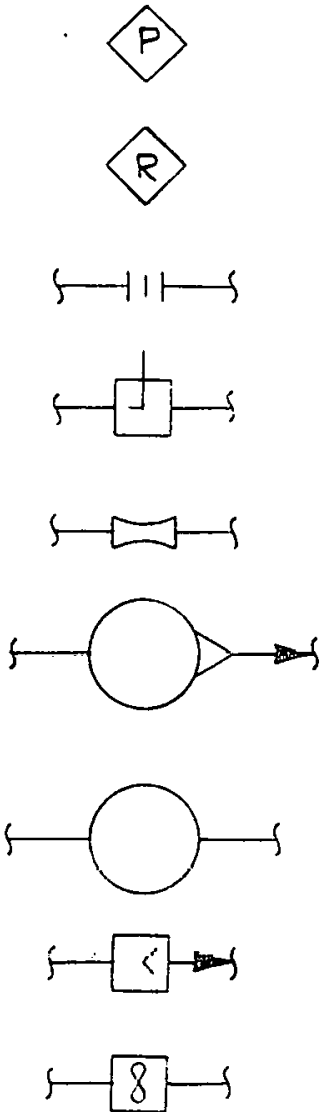

2.WAY VALVE.FAIL OPEN

2.WAY VALVE.FAIL CLOSED

2.WAY VALVE-FAIL LOCKED

3.WAY VALVE: SHOWN SPLITTING FLOW AND FAIL POSITION

DIAPHRAGM OPERATED VALVE WITH SIDE MOUNTED HANDWHEEL (OR TOP MOUNTED)

CHEMICAL SEAL

PURGE

RESET FOR LATCH TYPE ACTUATOR

ORIFICE PRIMARY ELEMENT

PILOT.TUBE OR ANNUBAR

VENTURI TUBE OR FLOW NOZZLE

ROTAMETER TYPE FLOW METER

INLINE TYPE FLOW METER OTHER THAN ROTAMETER

VORTEX FLOW METER

TURBINE METER 
ENG STD 60A3

PAGE 10

REVISION 0

DATE SEPTEMBER 1,1973
INSTRIJMENTATION

SYMBOLS \& IDENTIFICATION
FOSTER WHEELER

PROCESS PLANTS DIVISION

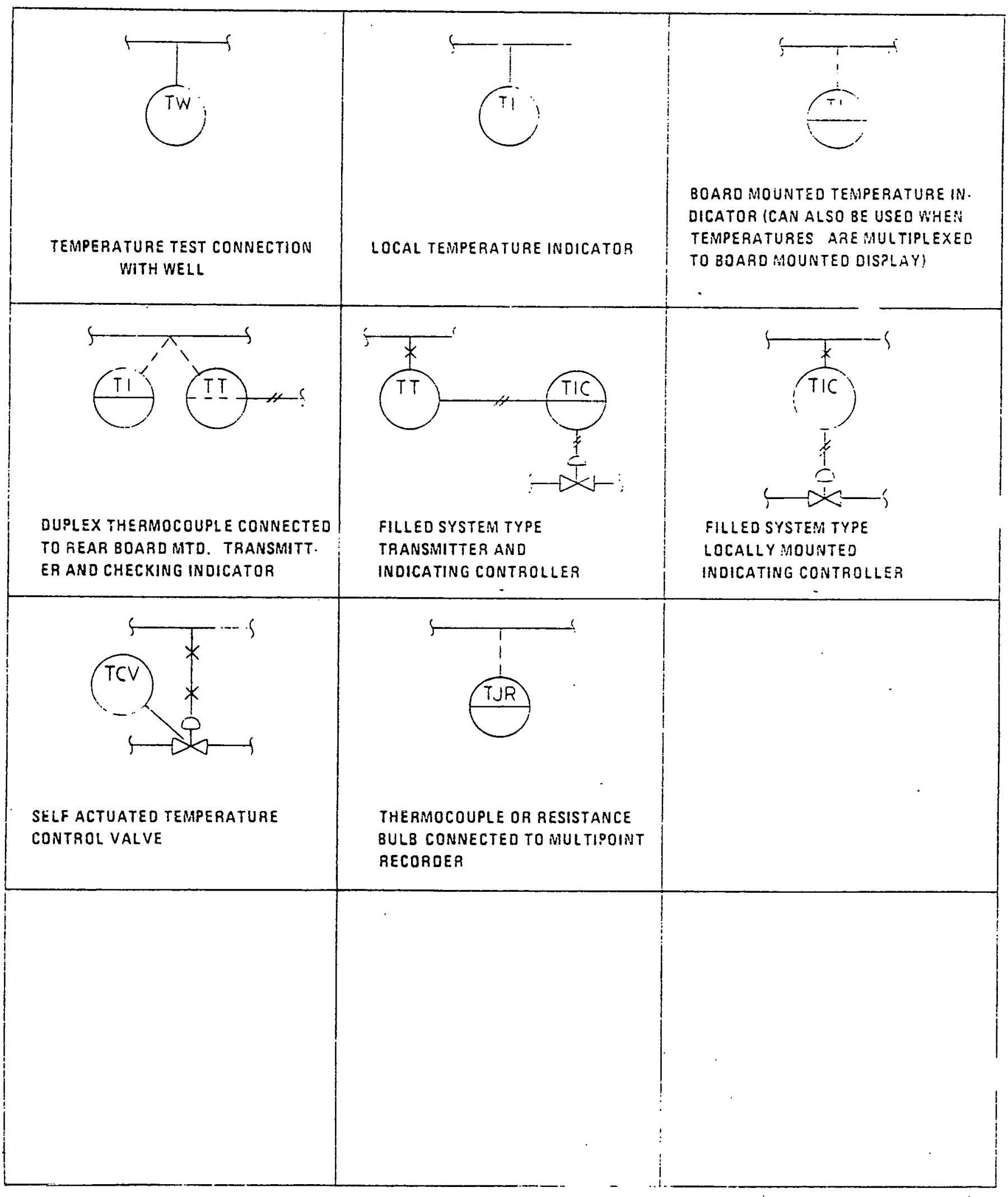


FOSTER

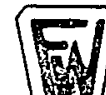

WHEELER

PROCESS
INSTRUMENTATION

SYMBOLS AND IDENTIFICATION
ENG STD $60 A 3$

PAGE 11

REVISION 0

DATE SEPTEIMBER 1,1978

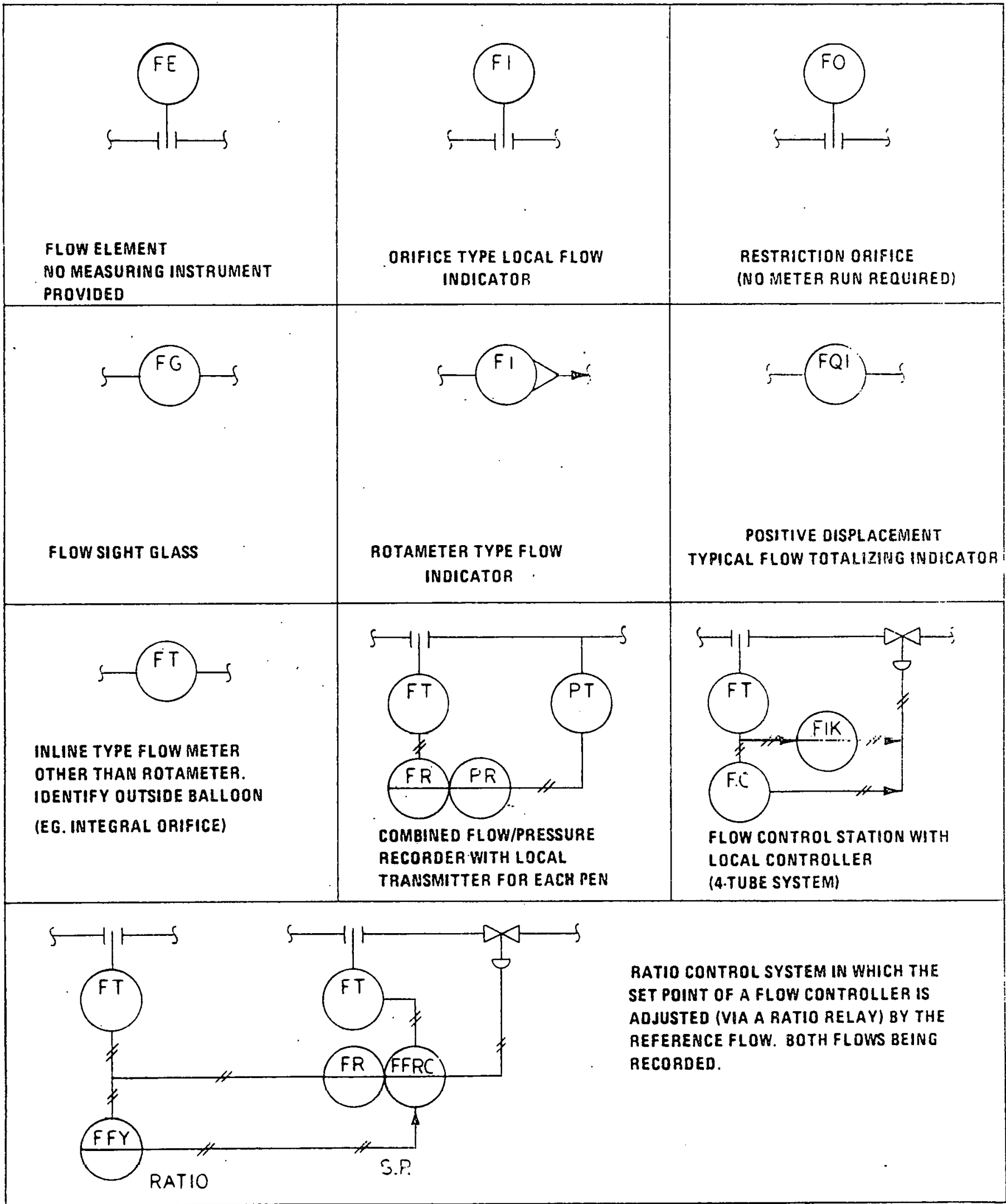


ENG STD 60A3

PAGE 12

REVISION 0

DATE SEPTEMBER 1,1978

INSTRIIMENTATIOI.

SYMBOLS AND IDENTIFICATION

FOSTER WHEELER

PROCESS PIANTS DIVISION

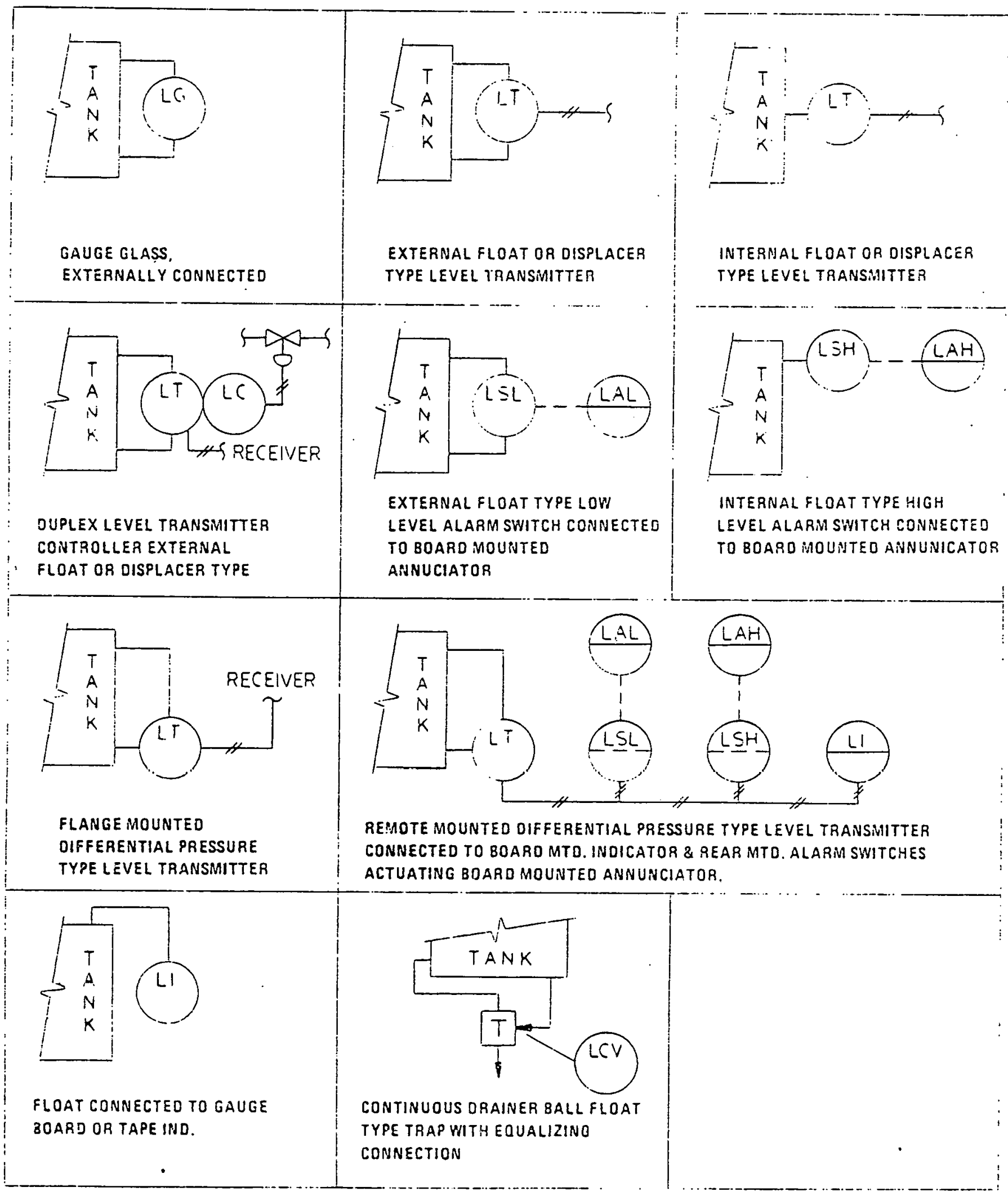


FOSTER

PROCESS

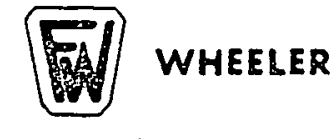

PLANTS DIVISION
INSTRUMENTATION

SYMBOLS AND IDENTIFICATION
ENG STD $60 A 3$

PAGE 13

REVISION 0

DATE SEPTEMBER 1,1978

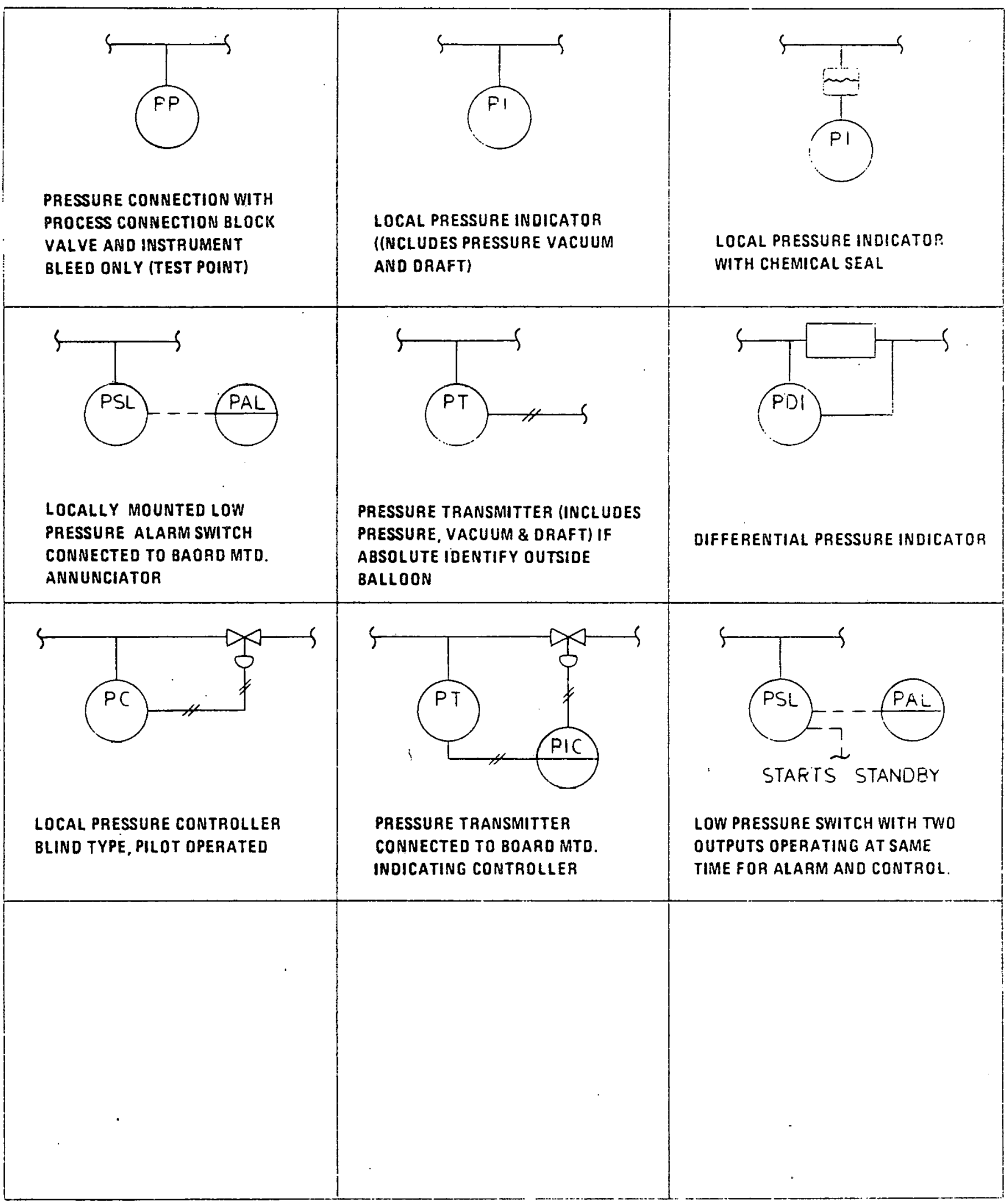


ENG STO $60 A 3$

PAGE 14

REVISION 0

DATE SEPTEMBER 1.1978
INSTRUMENTATION

SYMBOLS AND IDENTIFICATION
FOSTER TA WHEELER

88

PLANTS DIVISION

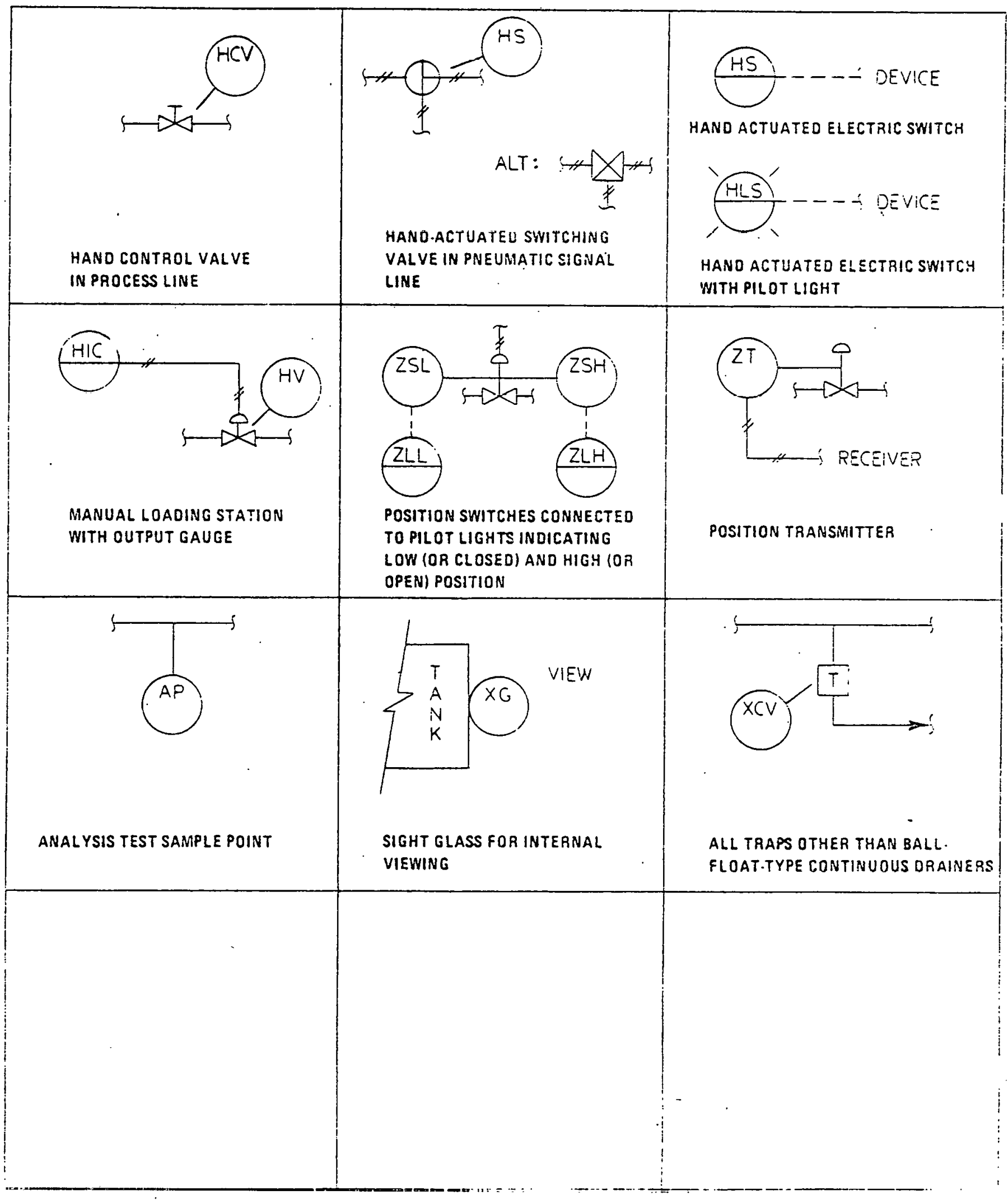




\begin{tabular}{|c|c|c|c|c|c|}
\hline & $\infty$ & & INSTRUMENTATION & JOB SPEC & 60A3 \\
\hline & (6) & WHEE LER & & $\begin{array}{l}\text { PAGE } \\
\text { PEVISION }\end{array}$ & 15 \\
\hline PROCESS & PLANTS & S DIVISION & SYMBOLS AND IDENTIFICATION & DATE & SEPTEMBER 1,1978 \\
\hline
\end{tabular}

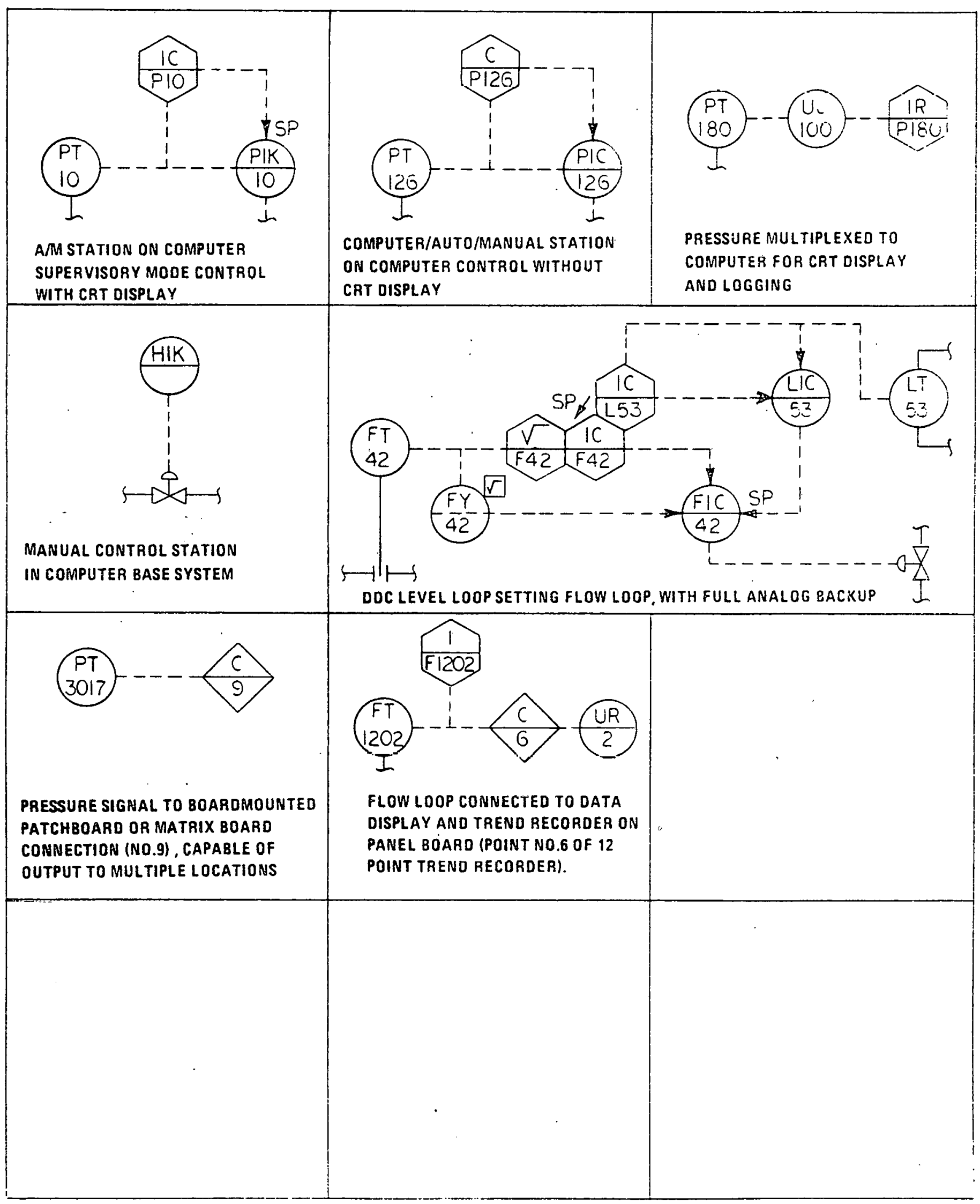


ENG STD 60A3

PAGE 16

REVISION 0

DATE
SEPTEMBER 1. 1978

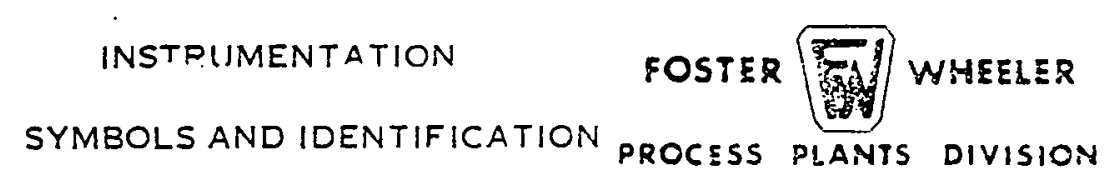

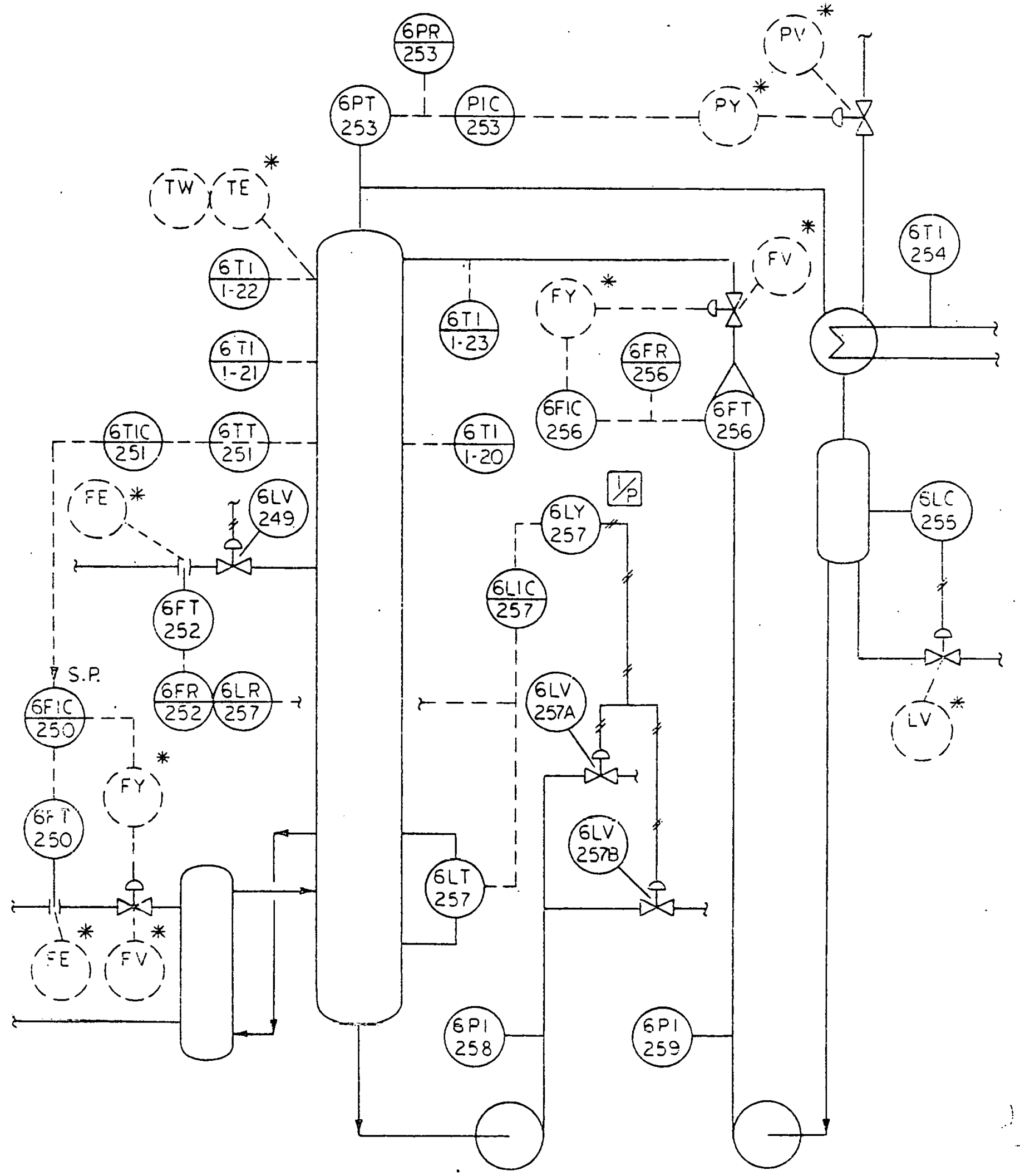

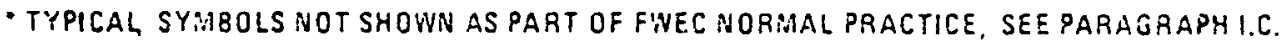


APPENDIX D.8

ELECTRICAL 


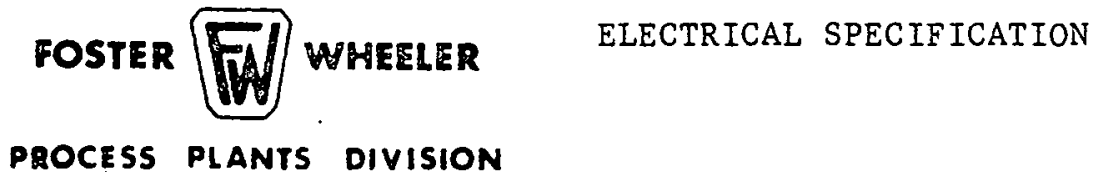

\begin{tabular}{cll} 
FAGE & REV & DATE \\
\cline { 2 - 3 } 1 & 0 & $6 / 1 / 79$ \\
2 & 0 & $6 / 1 / 79$ \\
3 & 0 & $6 / 1 / 79$ \\
4 & 0 & $6 / 1 / 79$ \\
5 & 0 & $6 / 1 / 79$ \\
6 & 0 & $6 / 1 / 79$ \\
7 & 0 & $6 / 1 / 79$ \\
8 & 0 & $6 / 1 / 79$ \\
9 & 0 & $6 / 1 / 79$ \\
10 & 0 & $6 / 1 / 79$ \\
11 & 0 & $6 / 1 / 79$ \\
12 & 0 & $6 / 1 / 79$ \\
13 & 0 & $6 / 1 / 79$ \\
14 & 0 & $6 / 1 / 79$ \\
15 & 0 & $6 / 1 / 79$ \\
16 & 0 & $6 / 1 / 79$ \\
17 & 0 & $6 / 1 / 79$ \\
18 & 0 & $6 / 1 / 79$ \\
19 & 0 & $6 / 1 / 79$ \\
20 & 0 & $6 / 1 / 79$ \\
21 & 0 & $6 / 1 / 79$ \\
22 & 0 & $6 / 1 / 79$ \\
23 & 0 & $6 / 1 / 79$ \\
24 & 0 & $6 / 1 / 79$ \\
25 & 0 & $6 / 1 / 79$ \\
26 & 0 & $6 / 1 / 79$ \\
27 & 0 & $6 / 1 / 79$ \\
28 & 0 & $6 / 1 / 79$ \\
29 & 0 & $6 / 1 / 79$
\end{tabular}

\section{REVISION INDEX}

JOB SPEC $\quad 60863-70 A 1$

PAGE 1

REVISION

DATE 


\section{FOSTER FA WHEELER \\ PROCESS PLANTS DIVISION}

ELECTRICAL SPECIFICATION

\section{TABLE OF CONTENTS}

I. SCOPE

PAGE

II. GENERAL 2

III. ELECTRIC SERVICE

IV. CONDUIT, CONDUIT FITTINGS \& THEIR INSTALLATION 3

V. WIRE AND CABLE 8

VI. LIGHTING DISTRIBUTION SYSTEM 10

VII. LIGHTING FIXTURES 14

VIII. LIGHTING AND RECEPTACLE PANELBOARDS 14

IX. LIGHTING TRANSFORMERS (DRY-TYPE) 15

$\mathrm{X}$, SWITCHES, WIRING DEVICES, WALL PLATES 17

$\begin{array}{lll}X I . & \text { CIRCUIT PROTECTIVE DEVICES } & 18\end{array}$

XII. DISCONNECT SWITCHES, MOTOR STARTERS 18

XIII. GROUNDING 19

XIV. TELEPHONE CONDUIT SYSTEM 21

XV. INSTRUMENT WIRING 22

XVI. ELECTRICAI FIELD TESTS 29

XVII. INEPECTION 29

XVIII. FOREIGN PROJECTS 29 


$\begin{array}{llll}\text { FOSTER WHEELER } & \text { ELECTRICAL SPECIFICATION } & \text { JOB SPEC } & 60863-70 A 1 \\ \text { PROCESS PLANTS DIVISION } & & \text { PAGE } & 1 \\ \text { REVISION } & 0 \\ & \text { DATE JURE } 1,1979\end{array}$

I. SCOPE

This specification specifies the general requirements for the design, equipment, materials and installation of the electrical facilities for a solar boiler house and solar field, located at Dalton, GA.

The facilities are limited to the electrical services associated with the building and.solar field and will include the following systems :

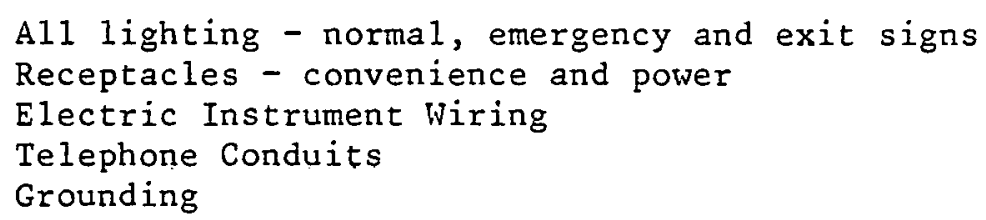

\section{A. Work Covered by This Specification}

The work covered by this specification shall include furnishing all labor, material, equipment and services to install the complete electrical system as specified herein.

Unless otherwise specified, this includes all electrical design necessary for the following work:

1. Installation of complete internal distribution system for power, including panelboards, disconnects, cable, conduit, and fittings.

2. Installation of complete distribution system for lighting including the necessary transformers, feeders, distribution panelboards, branch circuits, lighting fixtures, control switches, receptacles, cable, conduit and fittings.

3. Installation of empty raceways and cabinets for the telephone system.

4. Connection of permanently installed equipment for heating, ventilation and air conditioning system (supplied by others) or package air conditioning units.

5. Installation of complete ground system including fittings, clamps, conduit and wire.

6. Installation of complete electric instrument wiring system, including connections to field instruments and control panel and necessary cable, conduit, fittings and electrical boxes.

7. Installation of emergency lighting system, including exit signs, when specified. 


$\begin{array}{lcc}\text { JOB SPEC } & 60863-70 A 1 & \text { ELECTRICAL SPECIFICATION } \\ \text { PAGE } & 2, & \\ \text { REVISION } & 0 & \\ \text { DATE } & \text { June } 1,1979 & \end{array}$

I. SCOPE (Continued)

B. Work Not Covered by This Specification

The following equipment items and work sha1l be the responsibility of others :

Telephone system wires, cables, equipment and instruments to be furnished and installed by telephone company

II. GENERAL

A. Codes and Regulations

Except where indicated otherwise in this specification, the design, equipment, materials and their installation shall conform to the minimum requirements of the latest edition of the following applicable standards and codes:

1. US Dept. of Labor: Occupational Safety and Health Act (OSHA)

2. American National Standards Institute (ANSI)

3. National Fire Protection Association (NFPA)

4. National Electrical Safety Code (NBS Handbook H30)

5. National Electrical Code (NFPA 非70)

6. National Electrical Manufacturers Association (NEMA)

7. Insulated Power Cable Engineers Association (IPCEA)

8. Underwriters' Laboratories, Inc. (UL)

9. Local Laws and Regulations

B. Equipment and Materials

1. Equipment and materials furnished shall be as specified in this specification and shall satisfy all requirements dictated by the exposure of the area in which the equipment or materials are installed. 


\section{FOSTER}

FA WHELLER

II. GENERAL (Continued)

B. Equipment and Materials (Continued)

2. The equipment and materials furnished shall be labeled, listed, certified, accepted, or otherwise determined to be safe for the use by a nationally recognized testing laboratory such as one of the following:

a. Underwriters' Laboratories, Inc. (UL)

b. Factory Mutual Engineering Corporation (FM)

C. Classification of Areas

1. Natural Nonhazardous

Inless otherwise specified, the buildings and their facilities shall be classified as nonhazardous.

\section{ELECTRIC SERVICE}

Unless otherwise specified, the electric service characteristics shall be as. follows:

Power

Lighting receptacles, instrument power and miscellaneous
480 volt, 3 phase, 3 wire, 60 hertz, solidly grounded neutral.

$120 / 208$ volt, 3 phase, 4 wire, 60 hertz, solidly grounded neutral

In general, the building design shall be based upon receiving a power feeder at $480 \mathrm{VAC}$, as required for all electrical services.

Stepdown transformers shall be used to obtain all other voltages as required, such as $120 \mathrm{VAC}$ for lighting.

IV. CONDUIT, CONDUIT FITTINGS AND THEIR INSTALLATION

\section{A. General}

1. Except as noted herein, all wiring shall be run in approved conduit of one of lie fulluwing types:

a. Rigid steel, hot dipped galvanized

b. Intermediate metal conduit (IMC), zinc coated

d. Electrical metallic tubing (EMT) 
IV. CONDUIT, CONDUIT FITTINGS AND THEIR INSTALLATION (Continued)

\section{A. General (Continued)}

2. Wiring for fixtures in hung ceiling area may be run in flexible metallic conduit or armored type cable where permitted by local code.

3. Flexible steel conduit (maximum 6 feet long, 3/4" trade size) or armored type (BX) cable shall be permitted only in hung ceilings from recessed lighting units to associated outlet boxes.

4. Flexible liquid tight conduit shall be provided for connections to vibrating or rotating equipment (minimum 18" long), and as otherwise indicated on the drawings. Conduit shall be Anaconda American Brass "Sealtite", type NA flexible conduit, with $T \& B$ Series 5331 fittings as required, or approved equals.

B. Conduits shall be manufactured in conformance with the latest published standards of ASTM and UL and shall be as follows:

1. Conduit fittings for IMC shall be steel, threaded, of standard pipe dimensions, galvanized inside and out.

2. Electrical metallic tubing may be used for conduit installations below 2 inches diameter.

3. Electrical metallic tubing connectors and couplings shall be steel, smooth, galvanized, inside and out, with screw type compression fittings, and with nylon insulated bushing such as manufactured by $0 . Z$. or Crouse-Hinds type MW series or approved equal. Tubing shall be seamless or continuously threaded joints.

4. Threading of conduit shall be done using sharp dies and cutting oil to avoid tearing of the threads. Conventional thread lubricants may be used for making threaded joints.

5. A11 IMC and EMT shall be $3 / 4^{\prime \prime}$ minimum, except as otherwise noted, being true and smooth inside and out, and free of injurtous defects.

Rigid steel conduits shall be $3 / 4 "$ minimum for power and lighting and $1 / 2$ " minimum for control and instrumentation, unless otherwise noted. They shall be true and smooth inside and out and free of injurious defects. 
IV. CONDUIT, CONDUIT FITTINGS AND THEIR INSTALLATION (Continued)

B. (Continued)

6. Flexible steel conduit and armored type $B X$ cable shall be used only with terminal fittings approved for the purpose, as manufactured by 0.2 . or approved equal.

7. Conduit fittings, Crouse-Hinds form 8 or approved equal, shall be provided where specified or equired. A bushing and double locknuts shall be provided at the end of each conduit where it enters an outlet box, cabinet, panel or pul1 box. Bushings for conduit $2^{\prime \prime}$ and above shall be insulated grounded type (0.2. type BLC). For $3 / 4^{\prime \prime}$ to $1 \frac{1}{2} "$ conduits use insulated bushings ( 0.2 . type $B$ ). All joints in conduits shall be made with standard couplings unless neither conduit can be turned. In that case, the joint shall be made with 0.2 . type "SSP" split coupling or Erickson couplings. Running threads are not permitted.

\section{Installation}

1. Conduits installed underground shall be $1^{\prime \prime}$ minimum, secured to prevent shifting during concrete pour, and shali be a minimum of $18^{\prime \prime}$ below grade, 1 " below the finished floor slab, and where run below terrazzo or similar finish shall not protrude into the floor finish construction.

2. Exposed conduits shall be installed only after proposed runs have been checked on plans and after site inspection for interference with work of other trades. Exposed conduits shall be installed in parallel rows neatly racked at right angles and parallel to all walls, floors and ceilings and at structural members.

3. Conduits slidll be suppurted from ceilings by means of trapeze hangers and from walls by means of brackets utilizing the Unistrut (or approved equal) channel support system. All hangers, inserts, brackets and fittings shall be galvanized. Beam clamps shall be suitable for structural members and conditions. Hanger rods shall be galvanized steel or cadmium plated, $3 / 8$ in diameter minimum. Each conduit shall be fastened to the channel support (Unistrut No. $\mathrm{P}-1000$ or $\mathrm{P}-1001$ Series) with a suitable clamp (Unistrut P-1111 B throngh P-11.24 for TMC or rigid conduit, or Unistrut No. 1426 B through 1431 B for EMT). Al1 steel bolts, nuts, washers and screws shall be galvanized or cadmium plated. 
IV. CONDUIT, CONDUIT FITTINGS AND THEIR INSTALLATION (Continued)

\section{Installation (Continued)}

4. Conduits shall be supported every 10 feet (maximum), flexible conduits at least every $4 \frac{1}{2}$ feet.

5. Joints between aluminum steel components, if unavoidable, shall be made by coating the threads with zinc petroleum jelly compound or zinc chromate.

6. Where conduit is installed concealed with finished block, blazed block or tiled walls it shall be located so as not to cause a visible change in the finished appearance of such walls. Where required, deep boxes and/or equipment shall be used to comply with the above.

7. Conduits shall be protected or shall be plugged with suitable caps to prevent entrance of moisture or foreign material during construction.

8. All field bends shall be made with tools and equipment manufactured especially for this purpose.

9. Fish tape shall be drawn through all conduits installed for future wire to indicate that the conduit is clear of obstructions and ready for installation of wire.

10. In no case will the seller be permitted to cut a structural member, beam or column to facilitate the installation of conduit, etc., without the approval of Purchaser.

11. Exposed conduits at mechanical equipment shall be rigidly braced to the floors.

12. Where conduits cross expansion joints allowing for building movement, cross joints with approximately 24 " flexible conduit with a suitable copper strap bonded to the "rigid" conduit ends.

13. Openings in the outside walls and roof for conduit, duct, tray, bolts, etc., shall be made watertight after installation is completed. For conduit, this shall be done by providing pipe sleeves in concrete with a minimum clearance $\frac{1}{2} "$ around the conduit, and packing this sleeve with acrylic caulk or other approved sealing material.

14. Parallel conduit runs for instrumentation must be kept at least 12" away from hot surfaces. A minimum clearance of 6 " shall be kept where a conduit crosses a hot pipe. 
IV. CONDUIT, CONDUIT FITTINGS AND THEIR INSTALLATION (Continued)

D. Pull boxes and junction boxes NEMA Type 12 of proper size and design shall be provided as required to facilitate installation of wire and cable. All boxes shall be sized in accordance with NEC. Covers shall be held in place with corrosion resistant machine screws. Boxes shall be securely mounted to the building structure independent of the conduits entering or leaving the box.

E. Outlet Boxes

1. A NEMA Type 12 enclosure shall be furnished and installed for every outlet and switch. All enclosures shall meet the requirements for galvanized finish specified for steel conduits.

2. Enclosures shall be of dimensions suited and adapted to its specific location and kind of fixture or receptacle to be used and the number and arrangement of wires in conduits. Each enclosure shall be securely fastened to the building structure.

F. Before proceeding with the installation of conduits and enclosures the Seller shall check the location of all outlets and shall make any adjustments required by local condition. Where outlets or fixtures are fixed by specific dimensions on electrical drawings, or are shown on shop or field drawings, the Seller shall adhere to these locations. Switch outlets shall be located on the lock side of doors. Unless otherwise specified outlets shall be installed at the following elevations above the finished floor:

Convenience Outlets (Mechanical Spaces) Convenienre Mutlets (Finished Areas)

Telephone Outlets

Switch Outlets

Thermostats

Motor Controller Wall Bracket Outlets Toilet Room Outlets $3^{\prime}-6^{\prime \prime}$ Centerline

$1^{\prime}-6$ ' Centerline

$1^{\prime}-6$ ' Centerline

$4^{\prime}-2^{\prime \prime}$ Centerline

5'-2" Centerline

5'-0" Centerline

$7^{\prime}-10^{\prime \prime}$ Centerline

5'-0" Centerline 


$\begin{array}{lcc}\text { JOB SPEC } & 60863-70 A 1 & \text { ELECTRICAL SPECIFICATION } \\ \text { PAGE } & 8 & \\ \text { REVISION } & 0 & \\ \text { DATE } & \text { June } 1,1979 & \end{array}$

\section{FOSTER WA WHELER}

PROCESS PLANTS DIVISION

V. WIRE AND CABLE

A. Basis For Cable Sizing

1. The allowable current carrying capacity of cables shall be as specified in the National Electrical Code and IPCEA.

2. Feeders to distribution centers and transformers shall be sized based upon the maximum demand of initial loads. In general, feeders shall have a current carrying capacity equal to $125 \%$ of the maximum demand or nameplate rating, whichever is greater.

3. Sub-feeders from distribution centers to load shall be sized based upon the nameplate rating of the load.

4. Cables shall be sized to limit voltage drops as follows:
a. Feeders and Sub-feeders
$1 \%$ based upon maximum demand or nameplate
b. Motor Branch Circuits
$3 \%$ from the power center to the motor (using motor name- plate), but no smaller than the minimum size permitted by NEC
c. Lighting Branch Circuits
$2 \%$ from the panel to the farthest outlet

5. For lighting and power circuits 600 volts, and below, the smallest wire size shall be 非12 AWG, except that 非14 AWG shall be used for controls.

6. For instrument cable see Para. XV.

\section{B. Cable Construction}

1. Conductors 非 12 AWG and larger shall be stranded; conductors \#14 AWG and smaller shall be solid.

2. In general, for cables installed in conduit, cable insulation types shall be as follows: 
V. WIRE AND CABLE (Continued)

B. Cable Construction (Continued)

2. (Continued)

a. For services 600 volts and below, cables shall be 600 volt, heat and moisture resistant thermoplastic insulated, with nylon jacket, type THWN/THHN.

b. For fixture stems, \#14 AWG, 600 volt, Type SF-2 stranded fixture wire shall be used.

c. For instrument services PVC insulated wire and cable shall be used (See Para. XV).

3. Multiple conductor cable shall not be used for lighting and power work, except for:
a. Appliance cords
b. BX type armored cable as outlined in Paragraphs IV.A.2, IV.A. 3 and IV.B.6 of this specification.

4. All feeders and risers shall be tagged at both ends and in pull boxes or panel box gutters through which they pass.

5. All cable shall comply with applicable portions of IPCEA Standard S-61-402.

C. Motor Feeders and Control

Cable for power and control leads to motors 600 volts and below shall be installed in the same conduit when the power cable is \#2 AWG or smaller. For power cables larger than 非 AWG, power and control cable shall be installed in separate conduits.

\section{Color Coding}

1. The color coding for single conductor cables shall be as follows :

a. Power phase leads shall be black.

b. Multiwire lighting circuits and 2-wire branch circuits connected to the same system shall conform to the following:

Single Phase, 3 wire - Black (I1), Red (L2), White (N)

Three Phase, 4 wire - Black (L1), Red (L2), Blue (L3), White (N)

Three Phase, 3 wire Black (L1), Red (L2), Blue (L3) 


$\begin{array}{lcc}\text { JOB SPEC } & 60863-70 A 1 & \text { ELECTRICAL SPECIFICATION } \\ \text { PAGE } & 10 & \\ \text { REVISION } & 0 & \\ \text { DATE } & \text { JunE } 1,1979 & \end{array}$

V. WIRE AND CABLE (Continued)

D. Color Coding (Continued)

1. (Continued)

c. A11 control leads, including those for pushbutton stations, interlock circuits, instrument control circuits; current and potential transformer circuits, etc., shall be red.

d. Power supplies to/from instruments shall be yellow (live line) and white for the neutral.

e. All grounding conductors shall be either bare or have a green covering.

VI. LIGHTING DISTRIBUTION SYSTEM

A. Lighting Design

1. The lighting system shall be designed utilizing the minimum number of fixtures consistent with the illumination levels specified below in Paragraph VI.B.

2. Lighting fixtures shall not be located directly over equipment with exposed moving parts.

3. Lighting systems shall be designed to minimize glare.

4. In general, lighting circuits shall be switched from local switches.

5. Branch circuits using a common neutral conductor shall be arranged for minimum current in the neutral conductor. Loads on all phases shall be equally balanced as closely as possible.

6. Exit lights and exterior door lights are to be provided.

\section{B. Lighting Intensities}

The lighting system shall be designed for the levels of illumination tabulated below, when calculated on the basis of initial lamp lumens modified by a factor of $70 \%$ to allow for deterioration in lamp output in service. (Derived from the following publications: API Recommended Practice for Petroleum Refineries, API RP540, American National Standard Practice for Industrial Lighting, ANSI Std A 11.1, and American National Standard Practice for Office Lighting, ANSI Std A 132.1). 


\section{FOSTER WA WHELER}

PROCESS PLANTS DIVISION
ELECTRICAL SPECIFICATION

JOB SPEC 60863-70A1

PAGE 11

REVISION 0

DATE · June 1, 1979

VI. LIGHTING DISTRIBUTION SYSTEM (Continued)

B. Lighting Intensities (Continued)

The illumination level is defined as the mean of the maximum and minimum values of illumination calculated at various points throughout the illuminated area.

LOCATION

Laboratory

Control Rooms:

Vertical Face of Control Board

Consoles, Desks (Horizontal Level)

Rear of Panel

Telephone Equipment Room

Locker Rooms

Machine Shops:

Rough Bench \& Machine Work

Medium Bench \& Machine Work Rough Grinding

Stairways, corridors

Toilets and Washrooms

Air Conditioning Equipment

Boilers, Boiler Pumps, Compressors

Solar Field Ared

General Yard Areas

ILLUMTNATION LEVEL
FOOT CANDLES

100

$36^{\prime \prime}$
WORKING

PLANE

Floor

Horizontal Centerline of Panel

50

$30^{\prime \prime} *$

15

$48^{\prime \prime}+$

20

Floor

20

Floor

50

$36 " *$

100

$36^{\prime \prime} *$

20

Floor

30

Floor

10

Floor

20

Floor

3

Eround

0.5

Ground 


$\begin{array}{lcc}\text { JOB SPEC } & 60863-70 A 1 & \text { ELECTRICAL SPECIFICATION } \\ \text { PAGE } & 12 & \\ \text { REVISION } & 0 & \\ \text { DATE } & \text { June } 1, \quad 1979 & \end{array}$

VI. LIGHTING DISTRIBUTION SYSTEM (Continued)

B. Lighting Intensities (Continued)

LOCATION

Offices

General

Private

Washrooms

Stairways, corridors

Computer Operating Consoles

* Elevations from the floor $\begin{array}{cc}\begin{array}{c}\text { ILLUMINATION LEVEL } \\ \text { FOOT CANDLES }\end{array} & \text { WORKING } \\ \text { PLANE }\end{array}$

150

$30 " *$

150

$30 " *$

30

Floor

20

Floor

150

$30^{\prime \prime} *$

\section{Emergency Lighting}

1. When specified, sufficient emergency lighting shall be provided in all locations where illumination is required during an emergency.

2. The emergency lighting system shall be completely independent of the normal power supply. Emergency circuit wiring shall not enter the same raceway, cable, box, or cabinet with other wiring.

3. Under normal conditions, emergency lighting fixtures shall be operable and energized from the normal power source. Transfer to the emergency source shall take place automatically in the event of a normal source failure.

4. Emergency Battery Units

a. Wall mounted emergency light units are to operate when AC power fails. Units shall be dual light, $12 \mathrm{~V} \mathrm{DC}$, complete with battery, fully automatic high and low rate charger, indicating pilot light, test switch, and provisions for connection to $115 \mathrm{~V} \mathrm{AC}, 60 \mathrm{~Hz}$, single phase wiring. Each unit shall have enough capacity to provide light for a minimum of 90 minutes, while maintaining $87 \frac{1}{2} \%$ of nominal battery voltage. (Dual Lite No. 12-ED series, or approved equal). 
VII.

LIGHTING FIXTURES

\section{A. Fixture Types}

Type a. In general, fluorescent lamp fixtures shall be used for indoor areas requiring high illumination levels. Ballasts shall be rapid start Class $P$ thermal protected, high power factor ( 90 min.), filled with a thermosetting compound (leak-proof), have a rated noise level of $30 \mathrm{~dB}$ or less and be 1 isted by UL, and approved by CBM, and ETL. (Westinghouse Ventilated reflector type, \# H260. HV or approved equal).

Incandescent fixtures may be used where high illumination levels are not required.

Type b. Emergency lights shall be of the self-contained type

- with battery, solid state charger, automatic transfer in case of power failure. (Dual Lite \# 12-EDN-150-2-KB-A-V-LE-SST or approved equal).

Type c. Outside lights shall be mercury vapor (or high pressure sodium) with integral constant wattage ballast, (Holophane "Wallpack" cat. 488-000 or approved equal).

Type d. Vertical surface illumination of instrument panels shall be obtained by the use of fixtures specially designed for the purpose, with adjustable lamp setting for beam control and prismatic lens (Holophane No. 6044 series or approved equal).

B. Lamps

1. Fluorescent lamps shall be "cool-white" as manufactured by G.E., Westinghouse, or Sylvania. 2 lamp type F $48 \mathrm{~T} 12$ HO.

2. Mercury-Vapor lamps shall be "deluxe-white" as manufactured by G.E., Westinghouse or Sylvania.

3. Lamps for exit lights and emergency battery units shall be as recommended by manufacturer.

4. Incandescent lamps shall be inside frosted.

5. High pressure sodium (HPS) lamps shall be diffuse type "Lucalox" as manufactured by G.E. or approved equal. 


$\begin{array}{lccc}\text { JOB SPEC } & 60863-70 A 1 & \text { ELECTRICAL SPECIFICATION } & \text { FOSTER } \\ \text { PAGE } & 14 & & \text { PAMEELER } \\ \text { REVISION } & 0 & & \text { PROCESS PLANTS DIVISION } \\ \text { DATE } & \text { JUne } 1,1979 & \\ \text { VII. } & \text { LIGHTING FIXTURES (Continued) }\end{array}$

\section{F. Locations}

1. Fixture rows shall be mounted in straight lines, except where location is dictated by equipment location.

2. Space conditions must be coordinated with other trades to avoid interferences.

3. Each door to outside shall have an interior exit light and exterior door light.

4. In the case of large, office type buildings, exit signs with directional arrows shall be located in corridors, etc., indicating paths of egress.

G. Mounting

Refer to architectural drawings for ceiling finish schedules and to manufacturer's installation details for the required fixture mounting accessories.

In general, fluorescent fixtures in finished areas shall be of the recessed, static type. In unfinished areas, surface or pendant mounted fixtures may be used.

H. Wiring

1. Refer to Paragraph $\mathrm{V}$ for fixture wire specifications.

2. Splices within fixture housings or outlet boxes are to be made with wire nuts of the proper size.

VIII. LIGHTING AND RECEPTACLE PANELBOARDS

A. General

Panelboards shall be 3 phase, 4 wire, $120 / 208$ volt with main circuit breaker, bus bars and branch circuit breakers mounted in an enclosed cabinet (NEMA 12 ) with trim and door. Cabinet trim, door and finish shall be the manufacturer's standard. Main lug size, main breaker size and the number of branch circuit breakers shall be as indicated on contract drawings or material lists. Panel short circuit rating shall be 10,000 amps minimum. 
VIII. LIGHTING AND RECEPTACLE PANELBOARDS

B. Branch and main circuit breakers shall be as specified in Paragraph XI of this specification.

C. Bus bars and main circuit breakers shall be rated $100 \mathrm{~A}$ minimum.

D. AlI single pole breakers shall be arranged and connected to the main bus so that on 3 phase, 4 wire panels, any three adjacent breaker poles are connected to phase A, B and C respectively and that the same relationship of phase sequence is maintained.

E. One spare circuit shall be provided for each 5 active circuits in the initial design. Circuit loading shall not exceed 16 A for a 20 A breaker.

F. A durable, corrosion resistant lighting directory shall be installed at each panelboard.

\title{
G. Installation
}

1. In general, cabinets shall be set at such a height so that the topmost branch breaker shall not be more than 6 feet from the floor.

2. Top trim shall line up on all panels mounted adjacent to each other.

IX. LIGHTING TRANSFORMERS (DRY-TYPE)

In general, transformers under this category may be used for the following services:

\author{
Lighting \\ Receptacles \\ Instruments \\ Heat Tracing \\ Space Heaters
}




$\begin{array}{lcc}\text { JOB SPEC } & 60863-70 A 1 & \text { ELECTRICAL SPECIFICATION } \\ \text { PAGE } & 16 & \\ \text { REVISION } & 0 & \\ \text { DATE } & \text { June } 1,1979 \\ & \\ \text { IX. } & \text { LIGHTING TRANSFORMERS (DRY-TYPE) (Continued) }\end{array}$

\section{FOSTER WHEELER \\ PROCESS PLANTS DIVISION}

A. Basic Arrangement

1. Unless otherwise specified, lighting transformers shall be of a dry type, rated 480V-208Y/120V, and have the following features:

a. Sealed Insulation

b. $115 \mathrm{C}$ maximum temperature rise

c. Noise levels shall not exceed those listed in ANSI Standard C89.1, for the size transformer used

d. A minimum of $2-2 \frac{1}{2} \%$ FCAN and $2-2 \frac{1}{2} \%$ FCBN taps

Transformers shall be installed at lighting panel locations on the basis of one for each lighting panel.

2. All lighting transformers shall be protected by an individual overcurrent device in the secondary side set at no more than $125 \%$ of rated secondary current and a primary feeder overcurrent device set at no more than $250 \%$ of the rated primary current.

B. Accessories

1. Transformers shall be provided with standard accessories for the KVA and voltage ratings.

2. Transformers shall be provided with suitable vibration dampers, as manufactured by Fabreeka Products Co., type Fabcel Vibration Isolation Mounts or approved equal. Dampers shall be designed to suppress transmission of vibrations of $120 \mathrm{~Hz}$ and multiple harmonics.

\section{Installation}

1. Transformers $30 \mathrm{KVA}$ and below shall be wall mounted. Those above 30 KVA shall be floor mounted.

2. All transformer cases and neutrals shall be grounded. Refer to Paragraph XIII. 
X. SWITCHES, WIRING DEVICES, NALL PLATES

A. Each switch and wiring device shall have a suitable back-box sized in accordance with the National Electrical Code requirements. Refer to Paragraph IV.E of this specification.

B. Convenience receptacles shall be arranged in groups of not more than 6 for each lighting panel branch circuit.

C. In offices and control rooms, receptacle outlets shall be provided along the walls, spaced no more than 12 feet apart, with a minimum of 2 receptacles per room.

\section{Receptacles}

1. $15 \mathrm{~A}, 125 \mathrm{~V}$ convenience receptacles for office and control room areas shall be 2 pole, 2 wire grounding type, duplex, Hubbell Cat. No. 5262 or approved equal.

2. $15 \mathrm{~A}, 125 \mathrm{~V}$ clock hanger outlet, if required - 2 pole, 3 wire grounding type Hubbell Cat. No. 5235 or approved equal, with stainless steel plate.

3. $20 \mathrm{~A}, 125 \mathrm{~V}$, receptacles for appliance circuits shall be 2 pole, 3 wire grounding type, Hubbell Cat. no. 5362 or approved equal.

\section{E. Switches}

1. 20A, 120-277V single pole switch, Hubbell Cat. No. 1221 or equal.

2. 20A, 120-277V three way switch, Hubbell Cat. No. 1223 or equal.

\section{F. Device Plates}

1. All switches and receptacle outlets shall be provided with stainless steel plates (Hubbell or equal) suitable for the above receptacles and switches.

2. Where plates are to fit exposed conduit fittings, they shall be consistent with the type of fittings installed. 


$\begin{array}{lcc}\text { JOB SPEC } & 60863-70 A 1 & \text { ELECTRICAL SPECIFICATION } \\ \text { PAGE } & 18 & \\ \text { REVISION } & 0 & \\ \text { DATE } & \text { JunE } 1,1979 & \end{array}$

XI. CIRCUIT PROTECTIVE DEVICES

A. All receptacles located in areas susceptible to moisture indoor or outdoor, shall be protected with ground fault interrupter.

B. Al1 circuit breakers for $120 / 208$ volt panels shall be rated as follows:

1. Branch circuit breakers shall be $20 \mathrm{~A}$ at $120 / 240$ volts AC, single pole with noninterchangeable trip elements. UL listed interrupting capacity shall be 10,000 A symetrical at $120 / 240$ volts $A C$.

2. Main circuit breakers sha11 be $100 \mathrm{~A}$ minimum at 240 volts $\mathrm{AC}, 3$ pole with noninterchangeable trip elements and of panelboard manufacturers suggested type for distribution system capacity. UL listed interrupting capacity shall be 10,000 . A symmetrical at 240 volts AC.

C. Each circuit breaker shall be distinctly numbered when installed in a group with other breakers. Trip element calibration shall be indicated on each breaker.

D. Individually mounted circuit breakers shall be enclosed in a NEMA-12 type enclosure.

XII. DISCONNECT SWITCHES, MOTOR STARTERS

A. Fractional HP Motor Disconnect Switch

1. A 120 volt, single phase thermal protective switch (manual starter), Allen Bradley 600 series, Westinghouse type MS or approved equal, shall be used for disconnect means, unless otherwise noted.

2. Disconnect switch may be single pole, $20 \mathrm{~A} \mathrm{AC}$ only toggle switch (Hubbell No. 1221 or approved equal) where:

a. A switch is required in addition to a thermal overlaod switch.

b. The motor runs continuously, i.e., not automatically controlled.

Switches shall be installed in a suitable type FD box. 
FOSTER WHAEELR

PROCESS PLANTS DIVISION
ELECTRICAL SPECIFICATION

JOB SPEC 60863-70A1

PAGE $\quad 19$

REVISION 0

DATE June 1,1979

XII. DISCONNECT SWITCHES, MOTOR STARTERS (Continued)

B. Motor controllers for 3 phase, 480 volt motors shall be combination starters, full voltage, single speed, nonreversing, circuit breaker type $(22,000 \mathrm{~A}$ interrupting capacity) for system short circuit levels up to $22,000 \mathrm{~A}$. For system short circuit levels in excess of $22,000 \mathrm{~A}$, high interrupting capacity fusible disconnect switch type may be used. Starters shall be furnished in suitable NEMA 12 enclosures.

XIII. GROUNDING

A. The scope of work under this section of the specification shall include the following:

1. Design, furnish and install a ground network including rods, cable and fittings around building as outlined in Paragraph B below.

2. The Seller shall furnish and install all fittings, clamps, conduit and wire, to establish ground connections between all building services apparatus and conduits, and the ground network around building.

3. Connection of the building ground network to the existing plant ground system.

B. Suitable grounding shall be installed for:

1. Grounding for Safety of Personne1

Metallic noncurrent carrying parts of equipment connected to electrical circuits and of all major electrical equipment, such as motors, transformers, distribution panelboards, motor starters, etc., shall be grounded by the conduit or raceway connection to the power supply ground network or, if such equipment is isolated, to one or more ground rods, or other suitable grounding electrodes in accordance with NEC. Supplementary grounding shall be provided by a grounding cable connection from the equipment to the local ground network, at points indicated on contract drawings, or other suitable ground point as required by the NEC. 


$\begin{array}{lcc}\text { JOB SPEC } & 60863-70 A 1 & \text { ELECTRICAL SPECIFICATION } \\ \text { PAGE } & 20 & \\ \text { REVISION } & 0 & \\ \text { DATE } & \text { June } & 1,1979\end{array}$

XIII. GROUNDING (Continued)

\section{FOSTER WHEELER}

PROCESS PLANTS DIVISION

B. Suitable grounding shall be installed for: (Continued)

2. Grounding for Protection Against Lightning

Building protection, when specified, shall be in accordance with NFPA and local building codes.

3. Grounding for Electrical System Protection

Grounding and bonding for protection of the electrical system circuits and equipment shall be installed to minimize damage in case of ground faults by providing low fault impedance, thereby limiting the voltage to ground and facilitating the operation of overcurrent devices.

4. Instrument Signal Ground

A separate system shall be installed. for grounding of all computer/instrument equipment. It shall be completely isolated from the power equipment ground network. The system shall consist of a 100 of 非 $2 / 0$ ground cable connected to the required number of ground rods as specified in Paragraph XIII.C, installed beneath the computer floor.

C. Grounding Network (Grounding Electrode System)

1. In general, a ground network shall be installed around building and other elsctrical installations. The ground network shall consist of a main cable loop, aboveground connection points, and inspection points on all ground rods. Cable for main loop shall be $\# 2 / 0$ AWG and for branch ground runs shall be \#4 AWG stranded bare copper.

2. Insofar as possible copper ground loop conductors shäl be laid directly in the ground slack, without breaks or joints, and shall have 12" minimum cover. When unavoidable, underground joints shall be brazed, suitably covered and protected.

3. A ground rod shall be attached to the main cable loop at intervals as required to obtain resistance to earth not exceeding 5 ohms, except that the interval between ground rods shall not exceed 75 feet. Ground resistance shall be measured with a portable hand-cranked $40 \mathrm{ohm}$ "megger" ground testing instrument. When the ground resistance exceeds 5 ohms, additional ground rods or ground mats shall be installed to meet this specification. In lieu of additional rods, extensions to the rods may be added to drive the ground rods deeper into the earth. 
XIII. GROUNDING (Continued)

C. Grounding Network (Continued)

4. A protective sleeve of heavy wall PVC-schedule 40 pipe shall be used wherever grounding cable emerges to aboveground connections.

5. Ground rods shall be $3 / 4$ " diameter, length 10 feet or more as required by water table.

6. For the purpose of equipment grounding and electrical system protective grounding the grounding conductor shall be continuous from the equipment to the ground network of corresponding supply substation (by others).

\section{Material}

1. Ground wires shall be as specified under Section $V$ of this specification, sized in accordance with the NEC. Main loop cable size shall be as in Section XIII.B.

2. All motors, starters, disconnect switches, and transformers covered under this specification shall have ground lugs sized to accept same size wire as its feeder.

3. Grounding connectors, for aboveground work, shall be solderless, pressure type (bolt on) as manufactured by Burndy, or approved equal.

\section{TELEPHONE CONDUIT SYSTEM}

\section{A. General}

1. The Seller shall furnish all labor, materials and equipment required to completely install an empty telephone conduit system as shown on drawings.

2. Telephone wiring and equipment installation will be by the telephone company.

3. The quality of all material and workmanship involved in the telephone conduit system shall conform to the requirements for the corresponding equipment and accessories as specified for the Lighting and Power Systems. 


$\begin{array}{lcc}\text { JOB SPEC } & 60863-70 A 1 & \text { ELECTRICAL SPECIFICATION } \\ \text { PAGE } & 22 & \\ \text { REVISION } & 0 & \\ \text { DATE } & \text { June } 1,1979 & \end{array}$

XIV. TELEPHONE CONDUIT SYSTEM (Continued)

B. Telephone Outlet Box Plates

Telephone outlet boxes in masonry wall shall consist of 4 " square outlet box, see Paragraph IV.E, under plaster reducer, stainless steel plate, with $7 / 16^{\prime \prime}$ cord hole in the center for single gang.

C. Drag Wires

The Seller shall install a $100 \mathrm{lb}$. test pull cord in every telephone conduit, including the feeder conduits for the use of the telephone company in pulling their wires.

\section{$\mathrm{XV}$. INSTRUMENT WIRING}

A. In general, power for instruments shall be provided at 120 volts from the emergency lighting panels, or from the normal lighting panels when an emergency supply is not available. No lighting fixtures, convenience outlets or other type of utility outlets shall be connected to the instrument circuits. Where instruments are of a critical nature, such that loss of power would cause a shutdown or process upset, power shall be supplied from an uninterruptible power supply circuit.

B. Switches for field assembled instrument panels shall be as follows:

1. An instrument disconnect switch shall be provided in each branch circuit supplying a maximum of 6 non-potentiometer type instruments or recorders. Each potentiometer type instrument, electronic controller or analyzer shall have an individual disconnect switch.

2. Switches for temperature recorders and indicators shall be located on the back of the panelboards.

3. When instruments are not fused, all instrument switches shall be of the thermal overload type, 2-pole, connected to interrupt line and neutral wires. 
FOSTER

6

WHEELER

JOB SPEC 60863-70A1

PAGE

23

PROCESS PLANTS DIVISION

REVISION 0

DATE June 1, 1979

XV. INSTRURENT WIRING (Continued)

C. Wire and Cable

1. All wire pairs shall be twisted. The lay of the twist shall be approximately 30 times the outside diameter of the individually insulated conductor ( $1 \frac{1}{2}$ " to $\left.2 \frac{1}{2} "\right)$.

2. The minimum conductor size shall be \#16 AWG for one pair of cables and 非20 AWG for multipair cables, or as recommended by the equipment manufacturer.

\section{Color Coding}

a. The thermocouple wire and cable color coding shall be in accordance with ANSI C 96.1-1964.

b. The instrument signal wiring shall be:

Twisted pairs: White - positive

Black - negative

Cable outer jacket: Black

c. Intrinsically safe circuits only and no others, shall use:

Twisted pairs: Bright Blue - positive

Light blue or white with blue stripes, negative

Cable outer jacket: Bright Blue.

4. Cable Type and specification

a. Thermocouple extension wire shall be solid alloy wire pair of required calibration (per ANSI C96.1) to match thermosoiple well and instrument to which it is connectec. \#16 AWG for single pair cables. Thermocouple pairs are shielded with aluminum backed mylar tape, helically applied with $25 \%$ overlap. Aluminum shall be in continuous contact with a tinned, solid copper drain wire. Conductor insulation shall be $105^{\circ} \mathrm{C}$ PrC $15 \mathrm{mils}$ thick. Jacket for single pair cables shall be $20 \mathrm{mils}$ of $80^{\circ} \mathrm{PVC}$. 


$\begin{array}{lcc}\text { JOB SPEC } & 60863-70 A 1 & \text { ELECTRICAI SPECIFICATION } \\ \text { PAGE } & 24 & \\ \text { REVISION } & 0 & \\ \text { DATE } & \text { June } & 1,1979\end{array}$

XV. INSTRUMENT WIRING (Continued)

C. Wire and Cable (Continued)

4. Cable Type and Specification (Continued)

b. Electronic signal cables shall be $\# 16$ AWG stranded copper twisted pair cable with $15 \mathrm{mils} 150^{\circ} \mathrm{C}$ PVC insulation, shielded with aluminum backed mylar tape (as in a above) and with an overall jacket of $80^{\circ} \mathrm{C}$ PVC 20 mils thick.

c. Cables for alarms shall be same as b except not shielded.

\section{Grounding Practices for Equipment and Circuits}

1. Instrument circuits shall be grounded to reduce the effect of electrical interference upon the signal being transmitted. Instrument manufacturer's recommendations shall be carefully followed when locating this ground.

2. In general, the following rules shall apply:

a. The circuit of a DC loop shall be grounded at only one point.

b. Normally, the ground shall be located on the negative side of the DC loop power supply.

c. The AC power supply shall be grounded.

d. "In loops involving a computer, the actual physical location of the ground shall be as recommended by the multiplexer supplier.

e. When the connecting wiring for an instrument is of the shielded type, the shield shall be grounded at the control house end.

3. Grounding of Cable Shields

a. All shields of shielded pairs, with the exception of thermocouples, shall be grounded at one end only, the termination point to be in the control room. Continuity of the shield shall be maintained throughout the cable run and isolated from ground at instruments, junction boxes, etc. This shall also apply to multipair cable with overall shielding. 


\begin{tabular}{|c|c|c|c|c|}
\hline \\
\hline FOSTER & PA WHEELER & ELECTRICAL SPECIFICATION & $\begin{array}{l}\text { JOB SPEC } \\
\text { PAGE }\end{array}$ & $\begin{array}{c}60863-70 \mathrm{Al} \\
25\end{array}$ \\
\hline & & & REVISION & 0 \\
\hline PROCESS & PLANTS DIVISION & & DATE & June 1,1979 \\
\hline
\end{tabular}

XV. INSTRUMENT WIRING (Continued)

D. Grounding Practices for Equipment and Circuits (Continued)

3. Grounding of Cable Shields (Continued)

b. Where shielded thermocouple wire is used, the shield shall be grounded near the point of the circuit ground. For grounded junction thermocouples, this means at the thermocouple head. For underground junction thermocouples, this means at the control room.

c. Cables of thermocouple pairs having an overall shield shall have the overall.shield grounded at the panelboard for grounded and ungrounded junction thermocouples.

4. Thermocouple Circuit Grounding

a. The selection of grounded junction or nongrounded junction thermocouples is usually determined by the requirements of the device. to which the thermocouple is connected, i.e., grounded junction thermocouples cannot be used with transmitters, miV alarms, or recorders that do not have. isolated inputs.

b. Where nongrounded thermocouples are used, circuits shall be grounded at the receiving instrument.

E. Routing of Instrument Signal. Wiring

1. Signal wiring shall be adequately separated from power wiring and electrical equipment to minimize noise. The following are minimum required separation distances between the signal wiring and the power conductors for parellel runs. Crossovers shall be made at right angles.

POWER WIRING CAPAC ITY

$\begin{array}{rrrr}125 \mathrm{~V} & 10 \mathrm{~A} \\ 25 \mathrm{U} & \mathrm{V} & 50 \mathrm{~A} \\ 440 \mathrm{~V} & 220 \mathrm{~A} \\ 5000 \mathrm{~V} & 800 \mathrm{~A}\end{array}$

MINIMUM SEPARATION

SIGNAL WIRING OR THERMOCOUPLE WIRING IN RIGID STEEL CONDUIT

$$
\begin{aligned}
& 12 " \\
& 18^{\prime \prime} \\
& 24^{\prime \prime} \\
& 48^{\prime \prime}
\end{aligned}
$$

THERMOCOUPLE WIRING IN STEEL TRAY 


$\begin{array}{lcc}\text { JOB SPEC } & 60863-70 A 1 & \text { ELECTRICAL SPECIFICATION } \\ \text { PAGE } & 26 & \\ \text { REVISION } & 0 & \\ \text { DATE } & \text { June } & 1,1979\end{array}$

XV. INSTRUMENT WIRING (Continued)

\section{E. Routing of Instrument Signal Wiring (Continued)}

2. Intrinsically safe wiring shall be separated from all other control, signal, and/or power wiring, as set forth in Para. $K$.

3. Where a strong magnetic field is known to exist, signal wiring shall be routed with respect to this field to minimize interference (parallel to the magnetic flux lines).

4. Signal wiring shall not normally be routed through areas where ambient temperatures exceed $176 \mathrm{~F}(80 \mathrm{C})$.

5. No joints or splices shall be permitted in signal conductors except at terminal junctions in junction boxes.

\section{F. Instrument Wiring - General}

i. For intrinsically safe wiring, unfused paralleling of transmitters on one DC power supply shall be avoided; a separate pair of wires shall be used. This is also advisable for nonintrinsically safe wiring.

2. Controllers, recorders, indicators, computer inputs, alarm relays, etc. shall operate on the voltage signal measured across vendor specified calibrated resistors. Resistors shall remain in the loop when any of these devices are disconnected for servicing. Milliameters in a loop shall have a shunt.

3. Manufacturer's recommendation shall be followed when wiring special equipment such as turbine meters, magnetic klow transmitters, analyzers, etc.

4. Each pair of wires shall be adequately identified at any junction where other wires are pltstul. All terminalo chall be clearly identified. Terminals on the back of the main control panel shall be labeled with identification containing the instrument loop number.

\section{G. Wiring of Controls}

1. The instrument manufacturer's published limits on the resistive load which can be put on each signal generator shall not be excecdcd. Allowance shall be made for low power supply voltage level.

2. Voltage signal receivers shall have an input impedance of more than 100 times the impedance in the rest of the circuit. This includes the wiring and the output impedance of the signal source 
XV. INSTRUMENT WIRING (Continued)

\section{H. Wiring of Controls and Computers}

1. In transmission circuits containing both control and computer signals, the wiring practices shall be governed by the needs of the computer, as long as these practices do not conflict with intrinsic safety requirements.

2. The interface between computer and controls using a milliampere signal is a vendor specified precision resistor. The location of this resistor shall be the grounded side of the transmission loop or as recommended by the equipment manufacturer.

3. No loads other than computer loads shall be connected to the secondary of the computer isolation transformer.

4. All connections from the computer to the process controller shall be through circuits so designed that an open or short circuit on any computer input will minimize upset of the conventional control loop.

\section{J. Wiring of Thermocouples}

1. The impedance of receiving instruments shall be at least 100 times the sum of the impedance of the sensor and the connecting wire.

2. A thermocouple may be wired to two receiving instruments in parallel, such as a signal multiplexer and a temperature alarm, if both devices have an input impedance of one megohm or greater.

3. Grounding of thermocouples shall be as specified in Para. D.4.

4. Thermocouple terminal box connections shall be with tubular screw-type terminals and connections to make drain wire continuous from thermocouple to instrument, with isolation from ground in the terminal box. 


$\begin{array}{lc}\text { JOB SPEC } & 60863-70 A 1 \\ \text { PAGE } & 28 \\ \text { REVISION } & 0 . \\ \text { DATE } & \text { June } 1,1979\end{array}$

XV. INSTRUMENT WIRING (Continued)

\section{K. Wiring of Intrinsically Safe Equipment}

1. Intrinsically safe equipment shall not be connected with systems.

a. Operating at different voltage levels

b. Having different signal ground reference points

c. Approved for different hazardous location groups, unless approved electronic safety barrier devices are used.

2. Intrinsically safe equipment of different manufacturers shall not be mixed without investigating of compatibility of certification.

3. The installation of safety electronic barriers shall comply with the following:

a. Segregation of intrinsically safe leads and terminals

b. Protection of the barrier from dust, moisture, and exposure to an ambient temperature exceeding $120 \mathrm{~F}$ and severe vibrations. Exposure to direct sunlight or sources of radiant heat shall be prevented.

c. Proper mounting and grounding of the barrier.

d. Cable shielding, when used, shall not bridge over the barrier.

4. To ensure an intrinsically safe system when using barriers:

a. There shall be no intrusion of outside power sunrces exceeding the barrier rating on the nonhazardous location side of the barrier.

b. There shall be no intrusion of outside power sources, including other intrinsically safe circuits, on the hazardous location side of the barrier.

c. There shall be no energy storage system (capacitive or inductive), in excess of the maximum permitted by the barrier design, on the hazardous location side of the barrier. 
XV. INSTRUMENT WIRING (Continued)

K. Wiring of Intrinsically Safe Equipment (Continued)

5. Generally, the safety barrier resistance represents a high percentage of the load capability of a transmitter of a controller. Therefore, a check shall be made to ensure that the resistance required for cabling plus other series connected devices, does not exceed the maximum load impedance of the instrument.

XVI. ELECTRICAL FIELD TESTS

Refer to ENG STD 70A2 for complete testing requirements

XVII. INSPECTION

For shop information requirements, refer to the purchase order.

XVIII. FOREIGN PROJECTS

The specifications, codes, equipment ratings, material sizes, etc., referred to herein, are standard for the United States. In the case of projects located in foreign countries, it is understood the specifications, codes, equipment ratings, material sizes, etc., which apply in said country and are equivalent to those specified herein, shall complement those referred to in this country. 


\section{FOSTER Fif WHEELER D ELECTRICAL TESTING \\ PROCESS PLANTS DIYISION}

JOB SPECIFICATION 60863-70A2

REVISION INOEX

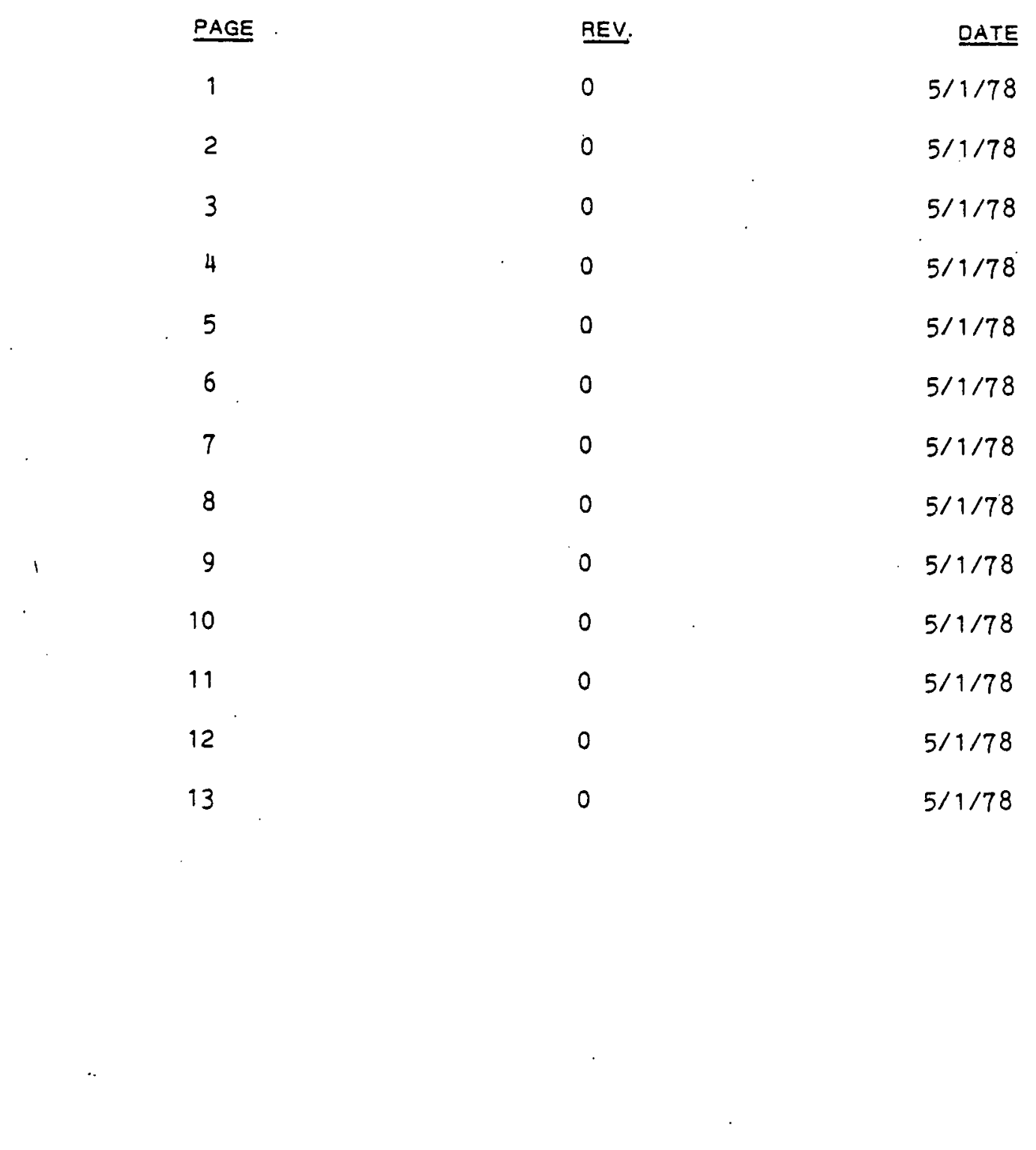

ENG. STD. 70A2 INDEX PAGE 1 ISSUE 0 DATE May 1, 1978 ״PAGES REVISED FOR THIS ISSUE ARE NOTED aY ASTEAISK. REASON FOR REVISION:

Standard Computerized 


\section{SCOPE}

This standard specifies Foster theeler's general responaibilities and procedures for the testing of electrical installations at a process plant jobsite, prior to completely energizing an integrated electrical system. Electrical testing at the jobsite will consist of 2 associated phases; the investigation (test analysis) and the inspection (perceptual analysis). Tests which are necessary to retain the manufacturer's guarantee will be conducted in accordance with instructions from the electrical equipment (material) manufacturer. In the absence of specific manufacturer's instructions, electrical field tests will be limited to those hereinafter specified for the various materials and eguipment. The inspection will consist of the combined physical examinations for unusual conditions of overheating, vibration, etc., mecharical and material defects prior to, during and after the energizing of an electrical installation.

\section{GENERAL INSTRUMENTS AND PROCEDURES}

In addition to normal testing equipment (voltmeters, ammeters, etc.) the following instruments and procedures are required for the tests hereinafter specified:

A. Short time insulation resistance measurements, hereinafter described shall be made with megohmmeter testers, (Megger), Resistance measurements shall be recorded after 60 seconds of applied voltage preferably during dry temperate weather. Test voltages shall conform to the following requirements:

1. Equipment rated $1000 \mathrm{~V}$ or less shall be rested using, a 500-volt "Megger."

2. Equipment rated $2300 \mathrm{~V}$ and above shali be tested using a 2500-volt "Megger" with range up to 200 megohms.

3. Equipment rated above $5000 \mathrm{~V}$ preferably should be tested at a voltage equal to $50 \%$ of the equipment rating but in no case should it be tested at less than $5000 \mathrm{~V}$.

B. Grounding connection resistance will be measured with a portable low resistance "Megger" ground testing instrument: Associated Research Inc. Vibraground Tester, Biddle Co. Earth Resistance Tester, or equal.

C. Temperature measurements shall be taken by a mercury thermoneter or by a thermal-sensitive resistor circuit. 
ENG STO $70 A 2$

PAGE 2

REVISION 0

DATE May 1, 1978

D. When available, service personnel under contract to Foster wheeler from local agencies shall perform the following tests:

1. Dielectric strength testing of insulating liquids.

2. Current leakage tests on cable for services above $5000 \mathrm{~V}$.

Where local agencies are not available, the necessary tests shall be performed by Foster wheeler personnel in accordance with this standard.

E. Prior to using testing and instrument devices, personnel shall be completely familiar with applicable manufacturer's instructions.

F. Setting and calibrating of protective relays shall be performed by service personnel under contract to Foster hibeler from a local agency capable of performing this function.

III. GENERATORS AND MOTORS

A. Insulation Resistance

1. All alternating current synchronous and inductive type machinery rated $10,000 \mathrm{HP}$ and below shall be subjected to an insulation test prior to connecting the machine tersinals to the motor feeder. A one minute "Megger" reading not less than the following minimum values at a machine temperature of $40 \mathrm{C}$ shall be observed before energizing:

MINIMUM MEGOHM VALUES FOR MACHINES

10,000 HORSEFOWER \& BELOW - CLASS A \& B INSULATION

$\begin{array}{llllll}\text { Volts: } & 110 & 440 & 550 & 2300 & 3000\end{array}$

Megonms: $\quad \begin{array}{llllll}1.11 & 1.5 & 1.6 & 3.3 & 4.0 & 5.0\end{array}$

For all other voltage ratings, the minimum insulation resistance value shall be determined from the following formula:

$$
P \operatorname{Ron}=1
$$

Where $R m=$ recommended minimum insulation resistance in megonms at $40 \mathrm{C}$ of the entire machine winding

$k V=$ rated machine potential in kilcvolts 


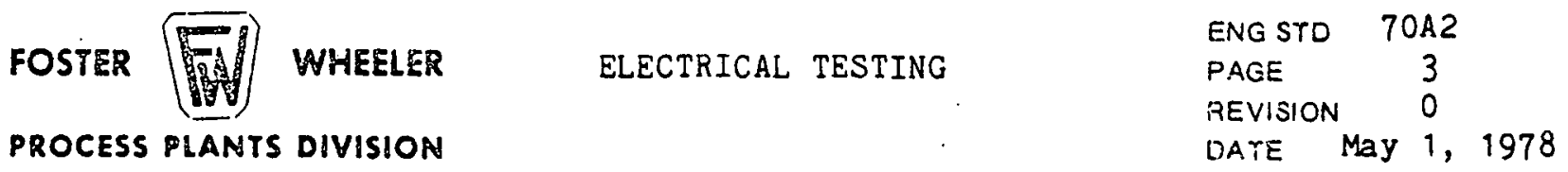

If the winding is not at a temperature of $40 \mathrm{C}$, the observed one minute resistance must be reduced by multiplying the observed value by the temperature coefficient of insulation resistance ( $\mathrm{Kt} 40 \mathrm{C}$ ) found in the following table:

$\begin{array}{lccccccccc}\text { Winding } & 0 & 5 & 10 & 15 & 20 & 25 & 30 & 35 & 40 \\ \text { Temp. C } & & & & & & & & & \\ \text { Kt 40C } & 0.065 & 0.09 & 0.13 & 0.19 & 0.25 & 0.36 & 0.50 & 0.70 & 1.0\end{array}$

2. The value of insulation resistance for low-yoltase motors may be determined by a single measurement.

3. The representative value of insulation resistance for mediumvoltage motors shall be determined by the dielectric absorbtion ratio calculated from 2 megohmmeter readings taken during the same test in accordance with the following reguirements:

a. For motors rated $750 \mathrm{~kW}(1000 \mathrm{HP})$ or less, the representative value of insulation resistance shall be the ratio of the 60 second reading to the 30 second reading.

b. For motors rated over $750 \mathrm{~kW}$ (1000 $\mathrm{HP}$ ) the representative value of insulation resistance shall ve the ratio of the 10 minute reading to the 1 minute reading (Polarization Index).

The minimum acceptable values are 1.25 for the 60 to 30 second ratio and 2.0 for the 10 to 1 minute ratio, provided the 30 second and 1 minute readings of the respective ratios equals or exceeds the requirement of Paragraph III.A. 1.

4. Three-phase machines with only 3 leads brought out shall have the insulation resistance measured with ali 3 leads connected together.

Three-phase machines with all 6 leads brought out shall have the insulation resistance of each phase measured separately with the other 2 phases grounded. The observed resistance of each phase shall be divided by 2 to obtain a value, shich after correction for temperature, can be compared with the recommended minimum value of insulation resistance.

5. If the corrected insulation resistance is below the minimum value, the machine must be dried out, as specified below.

It should be noted that for machines in good condition, insulation resistance readings of 10 to 100 times the recommended minimum values are not uncommon. 
ENG STD $70 \mathrm{~A} 2$

PAGE

ELECTRICAL TESTING

FOSTER

WHEELER

REVISION 0

DATE May 1, 1978

PROCESS PLANTS DIVISION

B. Drying Out Process

1. Machine windings shall be dried out by supplying heat from electric strip heaters, from heat lamps or by passing current through machine windings until a sufficiently high, rising insulation resistance is obtained. When current is applied through the windings, it shall not exceed the nameplate rating. The temperature maintained. during the drying out process should not exceed the following:

a. Class A Insulation

By a thermometer

$80 \mathrm{C}$

By resistance bridge or a thermal-sensitive resistor circuit (RTD)

$90 \mathrm{C}$

b. Class B Insulation

By a thermometer

$90 \mathrm{C}$

By a resistance bridge or a thermal-sensitive resistor clrcuit (RTD)

$110 \mathrm{C}$

2. Wound rotor induction machines rated $2300 \mathrm{~V}$ and above will be dried out by mechanically locking the rotor then applying a $440 \mathrm{~V}, 3$-phase, AC supply to the stator. Regulation shall be obtained from a resistance inserted in the rotor circult.

3. The applied voltage to produce drying current for otiner synchronous and induction machines rated $2300 \mathrm{~V}$ and above should not exceed $10 \%$ or the nameplate voltage and should not cause more than 60\% of nameplate full load current to pass through the windings. The voltage may be increased to $15 \%$ of nameplate, after a low insulation resistance increases to $1 / 2$ of the minimum value.

4. The insulation resistance shall be periodically recorded during the drying out process. In large high voltage machines the initial cold coil resistance value. will be high (20 megohms 20 C).* As the drying process continues and water vapor is boiled out from the internals of the machines, the insulaton resistance will rapidly fall to a minimum ( 6 megonms $90 \mathrm{C}$ ). As the drying process nears completion the insulation resistance will reverse its downard trend and settle at a steady hisher value (12 megohms $90 \mathrm{C})$. As the coils cool, after the drying process has been completed, the insulation resistance will rapidly rise (150 megohms $20 \mathrm{Cl}$."

- values for ccmparative purposes only. 
5. A period of 24 hours will usually be found sufficient for drying machines rated 600 to 2000 horsepower. Less time will be required for drying smaller machines. Windings which have been exposed to moisture will take longer to dry out than machines which have been properly stored.

C. Inspection

1. Prior to energizing the machine, all foreign objects between the rotor and the stator field coils should be removed. Brushes must move freely in their holders making a firm and even contact with collector rings. Voltage and frequency on the nameplate of the machine must correspond with the terminal line voltage and frequency. Belts for directly connected exciters (auxiliaries) shall be in proper running condition. All bearings must be properly filled with oil or grease. Machine shafts (rotors) shall be checked for alignment, shaft end play and rotation before being coupled to other machinery.

2. Drain plugs furnished on totally enclosed motors shall be removed and replaced with approved electrical drain fittings.

3. During the machine test-run, inspect for smoke, unusual noises, vibration and overheating. Operating conditions must be investigated and corrective action taken when the total temperature (ambient plus rise) exceeds the foilowing values:
a. For Class A insulation - $90 \mathrm{C}$
b. For Class B insulation - $110 \mathrm{C}$
c. For Class H insulation - $150 \mathrm{C}$

IV. TRANSFORMERS

A. Transformer windings shall have their insulation resistance tested:
a. Primary to ground
b. Secondary to ground
c. Primary to secondary

B. Sealed tank type transformers shipped assembled and filled with oil shall have an oil sample tested. For transformers shipped without oil, samples of oil shall be tested before filling the transformer. Transformer insulation shall be tested by a megohmmeter prior to filling and if required, insulation shall be dried using an approved method. 
ENG STD 7OA2

PAGE 6

REVISION 0

ELECTRICAL TESTING

FOSTER

WHEELER

DATE May 1, 1978

PROCESS PLANTS DIYISION

C. Test samples of liquids insulating immersed transfomer windings rated for $150 \mathrm{kVA}$ service and above must undergo a dielectric strength test. The test sample must withstand the following minimum voltage stress without an insulation breakdown when tested with a standard testing device:

ASTM D 877 Method

$\begin{array}{ll}\text { Oil } & 30 \mathrm{kV} \\ \text { Silicon } & 30 \mathrm{kV} \\ \text { RTE mp Fluld } & 30 \mathrm{kV}\end{array}$

ASTM D 1816 Method

$22 \mathrm{kV}$

$22 \mathrm{kV}$

$26 \mathrm{kV}$

If the voltage causing a breakcown is less than the minimum value, the liquid must be (dried) passed through a suitable filter press until the minimum voltage stress can be sustaired.

D. ASTM D 977 method is generally suitable for testing service-ased liquid dielectrics. Dielectric strength is tested with a standard testing device consisting of a test cup, instruments, control and high voltage power supply. The test cup internals shall support 2 butted electrodes, separated by a $0.1 "$ gap. Each electrode shail have a polished 1 ll diameter circuiar disc parallel to the other electrode at the gap interface. Sixteen ounces of liguid will be required for the test. After the electrode spacing has been checked with a standard round gage, having a diameter of $0.100 "$, the electrodes will be locked in position. After a suitable rinsing procedure, the test cup will be immediately filled with the liquid sample to be tested. The liquid should be at a temperature of $40 \mathrm{C}$. During the test the uniform rate of voltage increase should be about 2,000 volts per second. One breakdown should be made on each of 5 fillings of the test cup. Any individual test which deviates from the average by more than $25 \%$ will be test recorded and replaced by an additional test. An average of the first 5 tests within the allowable deviation will be taken as the dielectric strength of the Iiquid.

E. ASTM D 1816 method is similar to the method described above with the exception that it prescribes the use of spherically capped electrodes, separated by a $0.04 "$ gap. It is primarily suitable for testing new oils.

F. Completely assembled, factory-sealed-tank transformers sipiped with an insulating liquid successiully passing the preliminary dielectric strength test without filtering, may be put into the service after inspection if the cold coil insulation resistance between windings and between windings and ground tests above 6 megohms. In the event that the insulation resistance value falls below 6 megohms the transformer coils must be dried. 
G. Coils for factory sealed-tank-transformers shipped with an insulating liquid failing the dielectric strength test (before filtering) and coils for tank type transformers shipped separately without insulating liquid must undergo an out-of-liquid short-time "Megger" test for insulation resistance to ground and to other windings at a temperature between 60-70 C. The out-of-liquid insulation resistance must measure above one megohm per thousand volts of rated line voltage. Coils with insulation resistance values failing this requirement must be dried.

H. In the event that drying is necessary, the transformer coils will be heated to a temperature of $60-70 \mathrm{C}$ for a period of 24 hours by circulating current through the windings. This may be accomplished by short circuiting elther winding (HV or LV) and impressing $1 / 2 \%$ to 1\% of nameplate voltage (at normal frequency) across the other. Current should be limited to $1 / 5$ of the rated normal full load current by a reostat in series with the exciting winding. As the maximum coil temperature is approached, the circulating current should be gradually reduced until a steady state temperature condition is reached within the 60-70 $\mathrm{C}$ range.

I. The transformer tank and all fittings shall be inspected and tested for adequate sealing to prevent leakage of insulating liquid, entrance of moisture and loss of inert gas protection before the transformer is energized. During a leakage test the transformer tank shall not be subjected to a pressure greater than the amount specified on the nameplate. If there is no nameplate pressure specified a test pressure of $5 \mathrm{psi}$ will be used. The liquid dielectric will be slowly pumped into the sealed transformer until the pressure reads 5 psi. Joints, connections and gaskets will be checked with chalk dust to detect leaks. Any appreciable leakage will cause a pressure drop within a few hours.

J. The following precautions should be taken before placing the transformer in servine.

1. Check liquid level, bushings and other externally connected or gasketed devices, such as oil temperature and level gauges.

2. Check no-load tap changer to be sure it is in operating condition and at proper tap setting.

3. If provided, check operation of temperature alarm and level al,arm.

4. If provided, check operation of cooling fan relay and circuit, and fault pressure relay.

5. Check grounding of transformer. 
ENG STD 7OA2

PAGE 8

REVISION 0

DATE May 1, 1978

\section{SHITCHGEAR AND MOTOR CONTROL EQUIPMENT}

A. Before connecting cable leads to switchgear and wotor control equipment terminals, internal bus bars and connections shall unciergo a short time "Megger" test. "Megger" tests should be made preferabiy during dry, temperate weather.

The switchgear and motor control equipment qust be dried before going Into service if the insulation resistance, to ground falls below the following minimum values.

Tests will consist of megohmmeter measurements between each phase and grounded between phases.

$\begin{array}{ccc}600 \text { volts } & 601 \text { volts } & \text { above } \\ \text { and below } & 15,000 \text { volts } & 15,000 \text { volts } \\ & & \\ 3 \text { megohms } & 50 \text { megohms } & 200 \text { megonms } \\ \text { (breakers in) } & \text { (breakers out) } & \text { (breakers olit) }\end{array}$

Precautions required to obtain relfable insulation measurements will include disconnecting lightning arrestors, capacitors, potential transformers and secondary ground connections on current transformers.

On completion of the wire and cable terminations, a final insulation measurement using a megohmmeter shall be obtained for the entire system. Preierably, the measurement should be obtained just orior to the equipment being energized or, where applicable, prior to being turned over to the Client as being mechanically complete.

B. Oil Immersed contactors or circuit breakers must undergo the dielectric strength test. (See Section IV)

C. Prior to energizing the switchgear bus, the following items shall be inspected and tested for proper operation:

1. Control, protective and metering c1rcuits.

2. Contact alignment on all contactors and clrcuit breakers.

3. Setting and callbrating all overcurrent relays as hereinafter described where this is a part of Foster wheeler responsibility. 
FOSTER

河

WHEELER

ELECTRICAL TESTING

ENG STD 70A2

PROCESS PLANTS DIVISION

PAGE 9

REVISION 0

DATE May 1, 1978

4. Tanks for oil circuit breakers must be filled before tests begin. Place the circuit breaker in its "Test Position", (use a plug jumper where necessary) and make the following tests:

a. Close and trip the breaker with its control switch.

b. Manually trip the breaker.

c. Close and trip the breaker from any remote control positions.

5. Where the switchgear is arranged for a secondary selective system with automatic transfer scheme, the transfer circuits shall be tested by simulated fault and undervoltage conditions.

6. Operate other auxiliary devices.

7. Bolted bus joints, terminals and other connections for each separate equipment installation shall be checked for tightness.

\section{RELAY AND PROTECTIVE DEVICES}

A. Relay settings and coordination curves shall be furnished to field personnel. The following instructions apply where Foster wheeler is responsible for setting and calibrating relays:

1. All relays will be set in accordance with the relay tabulations furnished.

2. Relays with time characteristics shall be tested at 2 points on the time coordination curves to verify conformance with the manufacturer's data.

3. Protective relay settings and adjustments shall be made in accordance with manufacturer's applicable instruction booklets.

4. Circuit protective devices that have adjustable settings, such as molded case circuit breakers, shall be set in accordance with the system coordination requirements.

5. Heater elements of thermal overload relays used for motor protection shall be individually checked to ensure the proper element has been selected, installed and set for the motor nameplate full-load current. Where fuses are used, their ampere rating and NEMA class shall be checked for conformance with design requirements.

6. Other devices having variable timing characteristics, such as time-delay relays used in the automatic restart of motor drivers, shall be set and tested in accordance with the intended control function. 
ENG STD 7OA2

PAGE $\quad 10$

REVISION 0

\section{BATTERY AND BATTERY CHARGER}

A. The following precautions should be taken before placing the battery in service: (CAUTION: Type of battery should be checked in advance: Lead-ACid or NI-CAD).

1. Check the battery cells for proper level of electrolyte, for specific gravity of electrolyte by using a hycrometer, and for cracked jars. (Do not use hydrometer if it is a NI-CAD Battery).

2. Check the cell connections and wiring for continuity and polarity.

$$
\text { - } 6
$$

3. Check all protective devices for proper rating.

4. Check the battery output voltage.

B. Before energizing the battery charger, the battery should be connected across the output terminal in such a manner that the positive battery terminal is connected to the positive terminal of the charger. If the polarity of the battary terminals has been lost in a cable run, a polarity check can be made by openting the A.C. supply switch to the charzer and connecting the battery leads to the output terminals of the charger. Observe the deflection of the voltmeter on the battery charger. If it reads on scale, the battery is connected correctly to the output terminals. If the voltmeter reads off scale, reverse the battery leads at the charger outout terminals.

\section{EMERGENCY POWER}

Emergency generation facllities shall be checked for automatic starting, generation and power transfer during a simulated loss of yoltage.

IX. WIRE AND CABLE

A. Before being connected to equipment, installed wire and cable having all splices, potheads, stress cones, and metallic insulation shielding completed, shall be checked in accordance with the following requirements:

1. Test for continuity of all conductors and, where applicable, continulty of metallic insulation shielding to ground.

2. Test of insulation resistance of low-voltage and unshielded medium-voltage wire and cable using a megohmmeter according to the table in Paragraph IX.D. Measurements shall be made between phases and between each phase conductor and ground. 


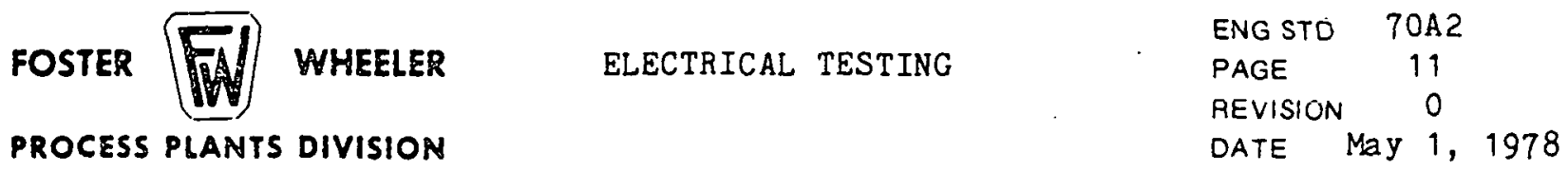

3. Test of insulation resistance of metal-clad, metal-sheathed and shielded medium-voltage wire and cable using high-voltage direct current in accordance with the requirements of Paragraph IX.B. Tests on metal-clad and metal-sheathed cable having no metallic insulation shielding shall be made between each phase and metallic covering and between phases. Tests on wire and cable having metallic insulation shielding shall be made between each phase conductor and the metallic insulation shielding for that conductor.

B. In addition, cables rated above $5000 \mathrm{~V}$, shall be tested for current leakage using a suitable DC high potential testing set. The initially applied direct current voltage shall be not greater than 3 times the rated AC voltage of the cables; preferrably, it shall be 2.4 times the rated voltage.

Test results shall be recorded on the "DC High Potential Test Report" (see Appendix). The cable shall be gradually stressed to minimize harmful surge currents. High voltage ozone resistance, rubber type cable must be capable of withstanding the following voltage stresses:

DC MAXIMUM TEST VOLTAGE

$\begin{array}{llll}\text { RATED AC RMS } & \text { CONDUCTOR } & \text { 100\% INSULATION } & 133 \% \text { INSULATION } \\ \text { VOLTAGE OF CABLE } & \text { SIZE, AWG } & \text { LEVEL (GROUNDED } & \text { LEVEL (UNGROUNDED } \\ & & \text { NEUTRAL) } & \text { NEUTRAL) }\end{array}$

$\begin{array}{rlrr}5000 \mathrm{~V} & 8 \text { \& over } & 25 \mathrm{kV} & 25 \mathrm{kV} \\ 8000 \mathrm{~V} & 6 \text { \& over } & 35 \mathrm{kV} & 35 \mathrm{kV} \\ 15000 \mathrm{~V} & 2 \text { \& over } & 35 \mathrm{kV} & 65 \mathrm{kV} \\ 25000 \mathrm{~V} & 1 \text { \& over } & 80 \mathrm{kV} & 100 \mathrm{kV} \\ 28000 \mathrm{~V} & 1 \text { \& over } & 85 \mathrm{kV} & -- \\ 35000 \mathrm{~V} & 1 / 0 \text { \& over } & 100 \mathrm{kV} & --\end{array}$

"Only wen ieguired for the specific project.

* These values are $80 \%$ of factory test values.

The above shall apply to the following insulations: Rubber type (EPR), Thermoplastic (XLPE); all with insulation shield.

The following procedures apply for this testing:

1. Leakage currents should be observed during voltage build-up. Faulty installations will cause leakage values to steadily rise after 30 seconds. 
ENG STO $70 A 2$

PAGE 12

REVISION 0

ELECTRICAL TESTING

FOSTER

AHEELER

DATE May 1, 1978

PROCESS PLANTS DIYISION

After application of the initial voltage, the voltage shall be raised uniformly to the test voltage in not less than 10 seconds nor more than 60 seconds. (The test apparatus may, however, require a slightly longer time to raise the voltage in some cases). Potheads and terminators isolated by switches, etc. from other equipment may be stressed at the test voltage along with the cable.

2. Immediately upon reaching the test voltage, the time and cursent reading shall be noted and recorded on the "DC High Potential Test Report" (see Appendix). The test shal? be for a 15 minute duration during wich current readings shall be made for the time intervals shown on the Test Report.

3. After the test voltage has been reached, the current readings should show a decreasing amount of current with time until a fairly steady current flows toward the end of the test time. If the current begins to increase during this time, the cable will be considered inadequate and wust be corrected or reolaced.

4. If the test must be interrupted for any reason before the required test interval is complete, the cable shall be grounded for an interval at least equal to that tine voltage was applied to the cable, before a new test can be started.

5. After completing the test, the cable shall be grounded for a time interval at least equal to the amount of time voltage was applied before the cable can be considered saie.

C. Short runs of cable (below 200 feet) rated for service above 5000 volts will be considered as satisfactorily installed if the meggered insulation resistance reads above the following minimum values:

CABLE SIZE

$$
\begin{gathered}
\# 6 \text { - \#4 AWC } \\
\$ 2-\# 1 / 0 \text { AWG } \\
\# 4 / 0-\# 250 \mathrm{MCM} \\
\$ 500-750 \mathrm{MCM}
\end{gathered}
$$$$
\$ 1000 \mathrm{MCM}
$$

\section{GROUNDED NEUTRAL}

5 megnhm.

4 megohms

3 megchms

2 megohms

1.5 megohms
UNGROUNDED NEUTRAL

6 megohms

5 megohms

3 megohms

3 megonms

2 megohms

D. Cable for service, i,000 volts and below, shall be tested with a 500-volt, megohm instrument. Insulation resistance for satisfactory power installations shall not be lower than the following minimum values. 
MINIMUM PERMISSIBLE INSULATION RESISTANCE IN MEGOHMS FOR 1000 FEET RUNS AND BELOW

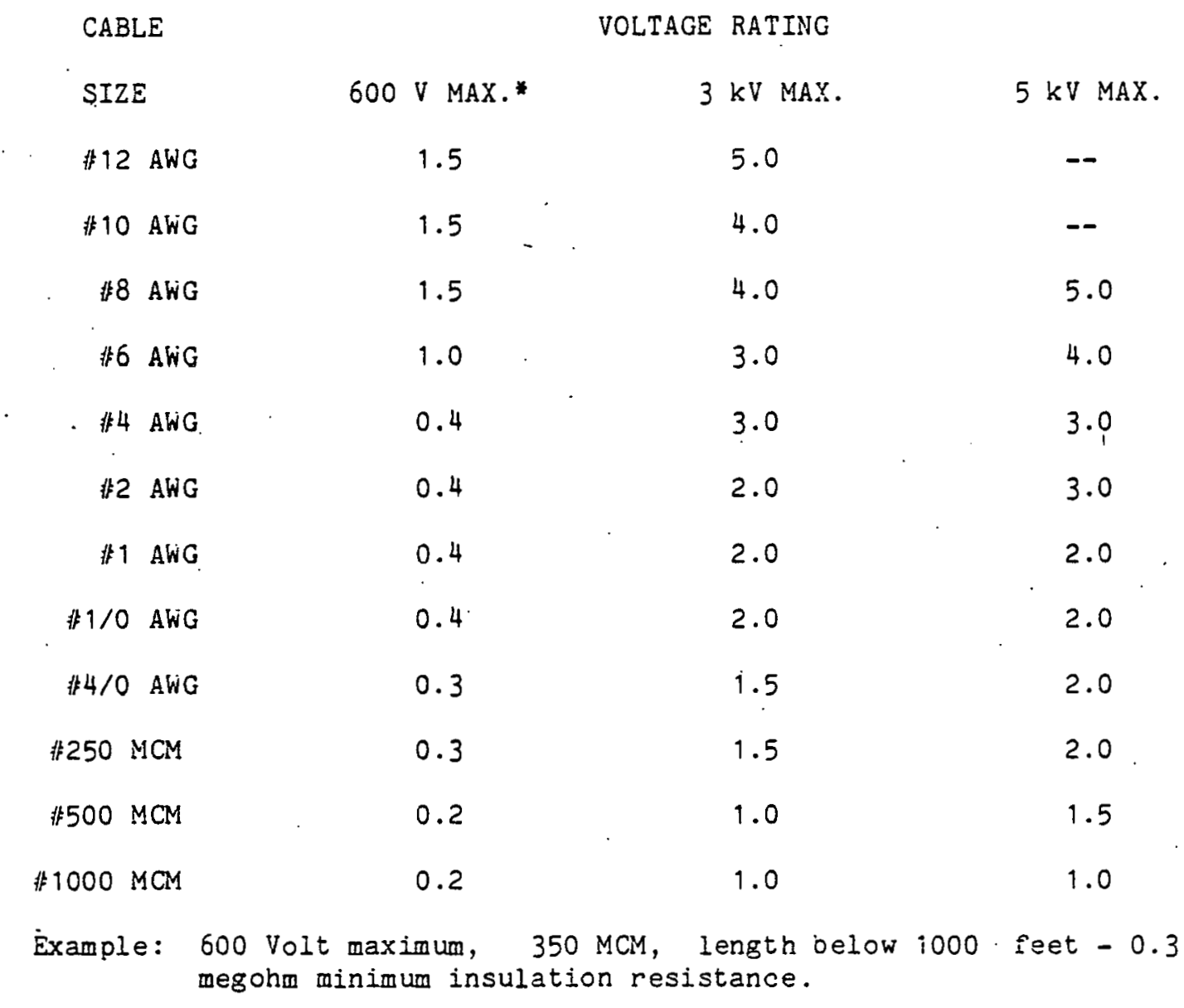

E. For minimum: permissible insulation resistance for cable runs more than 1000 feet, multiply the table values by the ratio 1000 feet divided by actual feet of in .

* Minimum permissible values of insulation resistance for lighting branch circuits $(600 \mathrm{~V})$ shall be $1 / 2$ of the indicated values when fixtures (before lamping) and receptacles are included in the test.

X. GROUNDING

The ground system shall be checked using a suitable "Megger" to insure that ground resistance values comply with requirements of the electrical specification (ENG STD 7OA1). 


\begin{tabular}{|c|c|c|c|c|c|}
\hline & $E$ & & ELECTRICAL TESTING & ENG STD & $70 \mathrm{~A} 2$ \\
\hline FO & WW & WHEELER & DARD & $\begin{array}{l}\text { PAGE } \\
\text { REVISION }\end{array}$ & $\begin{array}{l}\text { Appendix No. } 1 \\
0\end{array}$ \\
\hline ROCE: & VTS & ON & DC HIGH POTENTIAL REPORT & DATE & May 1, 1978 \\
\hline
\end{tabular}

Customer:

Location:

Plant:

Foster Wheeler Contract:

\section{CABLE}

Cable No:

From:

To:

Length:

Ft.

Cable Description:

Manufacturer:

Insulation Type:

Shielded?

Conductor Size:

$3-1 / c$, or

$1-3 / \mathrm{C}:$

Rated Voltage: $\mathrm{kV}$

Operating Voltage:

$\mathrm{kV}$

Rated Temp.:

${ }^{\circ} \mathrm{C}$

TEST

Initial DC Voltage:__

Test DC Voltage:

Temperature at Test:

${ }^{\circ} \mathrm{C}$

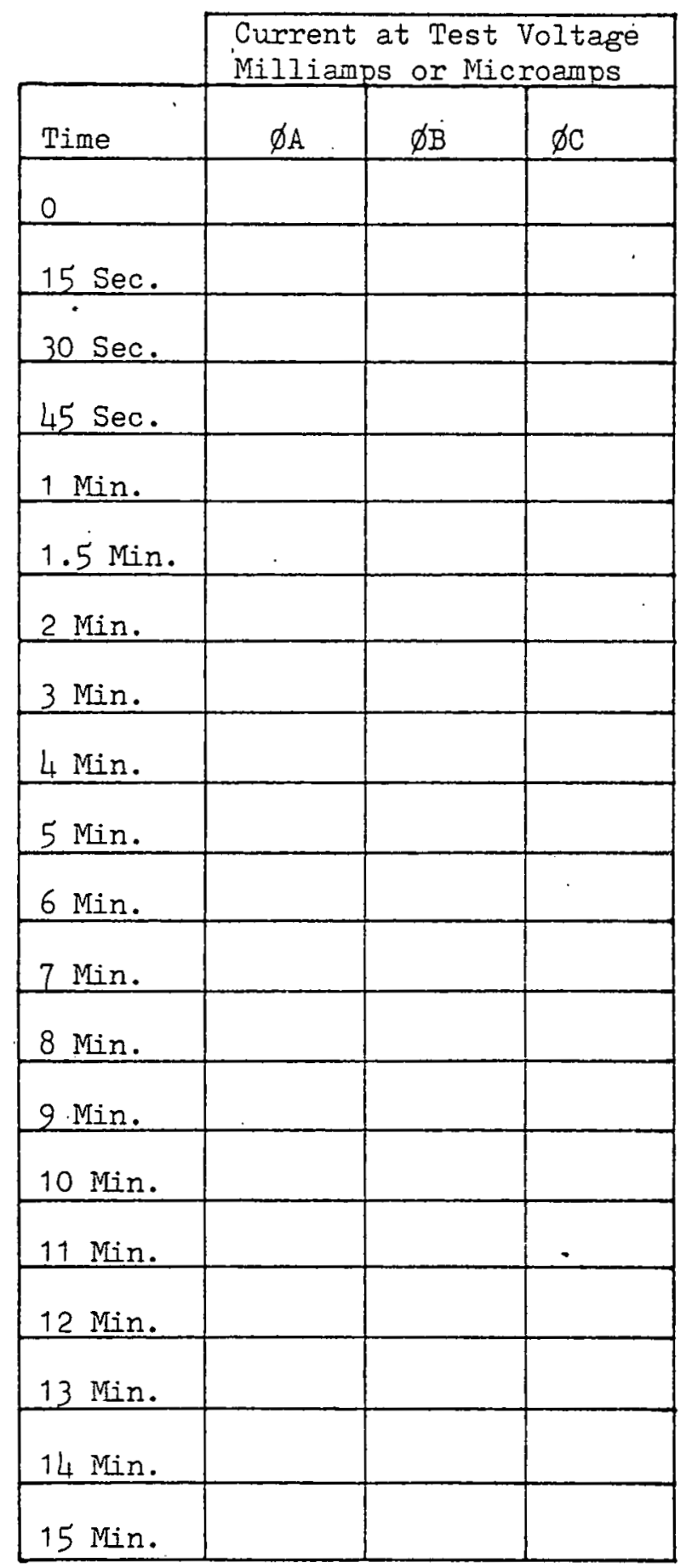

Comments :

DATE :

Tested By:

Witnessed 'By:

Company:

Company : 
APPENDIX D.9

PROTECTIVE COVERING 
U.S. Department of Energy

Solar Steam Generation
FOSTER WHEELER ENERGY CORP. FWEC Contract 11-60863

JOB SPECIFICATION NO. 60863-82AI

\section{INSULATION}

The subject specification is issued herewith per index of pages noted below. If this is a later revision than now in your possession, please destroy superseded pages and insert the revised pages.

Initial issue $x$
Entire specification reissued
Revised pages only attached

REVISION INDEX

\begin{tabular}{cc} 
Page & Rev \\
\cline { 2 - 2 } 1 & 0 \\
2 & 0 \\
3 & 0 \\
4 & 0 \\
5 & 0 \\
6 & 0 \\
7 & 0 \\
8 & 0 \\
9 & 0 \\
10 & 0 \\
11 & 0 \\
12 & 0 \\
13 & 0 \\
14 & 0 \\
15 & 0 \\
16 & 0 \\
17 & 0 \\
18 & 0 \\
19 & 0 \\
20 & 0 \\
&
\end{tabular}

* Pages revised for this issue are noted by asterisk.

Iэsuc No. 1 Date 4/25/79

Basis: Dow Chemical Co.

Specification 


\subsection{GENERAL}

1.1 Furnish and install insulation and finishes as shown on the pipeline schedule and as specified herein.

1.2 The preparatory work of others shall be examined and objections thereto reported to the owner's representative before proceeding with the work. The contractor shall ascertain if any surfaces are to be painted before insulating, and shall not proceed with the insulating vork until painting is completed.

1.3 Lines are to be tested and made tight before insulation is applied. Under no circumstances shall lines or fittings be covered while wet or in frosted condition. No threaded fittings or connections shall be covered until inspected and approved by the Dow representative as being in accordance with the drawings and specifications and made up tight with the proper thread sealant.

1.4 Unpainted surfaces shall be brushed clean before applyint insulation, using wire brush where necessary, and all loose material, dirt, and grease shall be removed from surface before covering is applied.

1.5 Insulation shall fit the surface of the pipe and equipment snugly and shall be fabricated or molded so as to leave not more than $1 / 8$ " void between the surface to be insulated and the insulation itself.

1.6 All metal protrusions through insulation shall be flashed to prevent entrance of water.

1.7 Joints shall be close fitting and water-tight.

1.8 All materials and accessories shall, be installed per manufacturer's recommendations.

1.9 All insulation shall be kept dry and protected from the weather at all times. Any insulation found to be wet or damaged shall be replaced by the contractor at no cost to Dow.

1.10 Do not cover lines that are in a wet or frosted condition.

1.11 Wherever possible, pre-molded insulation blocks shall be used to cover valves, pipe fittings, etc.

1.12 Insulation shall not interfere with any moving parts of valves, etc.

1.13 Thermowells and resistance devices shall not be completely covered.

1.14 On single layer insulation tie-ins to existing insulations, the new weather coating or outer jacket shall overlap the existing covering by at least 6 inches. 
INSULATION

\subsection{GENERAL (CONTINUED)}

1.15 The type and thickness of insulation required to meet the temperature and service conditions which are to prevail on the various surfaces to be covered shall be according to the class table in the respective insulation specification. The materials and thickness specified in these classes indicate the minimurn of insulation value acceptable, and the contractor shall furnish the materials specified with commercial dimensions in closest accord with, but not less than, the specified thickness. Substitute materials may not be used without prior written approval of the Owner's representative.

1.16 The naterials used, methods of application, and quality of work done shall at all times be subject to the inspection and approval of the Owrer's representative.

1.17 The Contractor shall make available scaffolding and/or rigging and assist the Owner's representative in making any tests or inspections when, in the opinion of the representative, such assistance is necessary or required.

1.18 Safety Rules, All insulating operations shall be conducted in conformance with the owner's approved safety regulations.

1.19 Operating areas shall be kept free of accumulated waste materials or rubbish caused by this work.

1.20 All wires and bands used to secure insulation in place shall be applied in accordance with the quoted insulation specification. Ends of bands and tie wires shall be tucked under to minimize hazards to personnel.

1.21. All weather barrier materials and vapor barrier materials shall be either black or gray as specified in the specific insulation specification.

\subsection{APPLICATION}

2.1 Pipe insulation shail be in sectional or segmented form. Insulation for fittings and irregular surfaces shall be segmented, pre-formed, block; or insulating cement. All joints shall be tight fitting and all voids filled with broken block insulation or with insulating cement and thoroughly sealed.

\subsection{P̄ipe}

2.2.1 Insulalion shall be applied in single layer construction to the thicknesses specified.

2.2.2 $\wedge 17$ joints shall be butted tightly togehter and securely wired or barded on $9 "$ centers.

2.2.3 Ends of wire loops shall be twisted together, bent over, and driven into the insulation so as to leave no projections. 
INSULATION (CONTINUED)

\subsection{APPLICATION (CONTINUED)}

2.2.4 Insulation shall be applied by the broken joint method. For multiple layer construction, the second layer shall be applied so that both circumferential and longitudinal joints are staggered.

2.2.5 On multiple layer construction, each layer shall be wired or banded separately.

\subsection{Fittings, Valves, and Flanges}

2.3.1 Fittings on piping $2 \frac{1}{2} "$ and larger and the bodies of the flanged valves shall be insulated with block insulation to a thickness equal to that on adjacent piping.

2.3.2 Flanges shall be covered with sectional pipe or block insulation to a thickness equal to that of the insulation on the adjacent piping.

2.3.3 The block insulation on the bodies of $2 \frac{1}{2} "$ and larger fittings and valves and on all flanges shall be securely wired or banded in place. on flanges, the insulation shall be of such length as to extend not less than $2^{11}$ or a distance equal to the insulation thickness, whichever is greater, over the adjacent pipe insulation on each side of the flange. All voids shall be filled with insulation material and shall be thoroughly sealed. The total thickness of the insulation shall be equal to that on the adjacent piping.

2.3.4 The insulation for fittings and the bodies of valves on pipe $2 "$ and smaller shall consist of a built-up layer of insulating cement. Total thickness of insulation shall.be equal to that on adjoining pipe. Valve and fitting insulation shall be extended over the piping insulation a distance equal to the insulation thickness.

\subsection{Bends}

2.4.1 Bends shall be covered by mitered sectional insulation or preformed bends. Each ser.tion shall be securely wired or banded in place. All joints shall be thoroughly sealed.

\subsection{FINISH-WEATHERPROOF}

\subsection{Pipe}

3.1.1 Pipe insulation shall be covered or finished with $\mathrm{Hu}-\mathrm{Al}$ style TGH-1000-VB Heatherproof jacketing. Alpha Associates, Hoodbridge, New Jersey.

3.1.2 The jacketing shall be securely lapped and stapled on 2" centers to the insulation. The lap shall be turned down to shed water. The mininum longitudinal and circumferential lap shall be $2 "$.

3.1.3 Circumferential joints shall be securely taped to prevent entry of any moisture. 
INSULATION (CONTINUED)

\subsection{FINISH-HEATHERPROOF (CONTINUED)}

3.2 Fittings, valves, flanges, and beads shall be finished with a weatherproof mastic. Edges shall be lapped at least 2" and the insulation finish shall be smooth, neat, and pinhole free.

4.0 WIRES AND BANOS

4.1 Wire and Band Materials

4.1.1 For securing all single and outer layer insulation and for all weatherproof finishes using a roofing jacket, wires and bands. shall be Type 302 or 304 stainless steel.

4.1.2 Bands and wires for securing inner layer insulation shall be. galvanized steel.

4.1.3 Wires and bands shall be spaced on 9 " centers. 
5. IRSULATION MATERIALS

5.1 PIPE INSULATION

PHILIP CAREY CORP. CAREYTEMP 1500

ONENS CORNING KAYLO 10

5.2 WEATHERPROOF JACKETING (UITH VAPOR BARRIER)

ALPHA ASSOSIATES, INC. HU-AL STYLE TGH I000-VB (WHITE) WOODBRIDGE, NEIV JERSEY

5.3 PRE-MOLDED ONE PIECE PVC INSULATING FITTINGS

ZESTON FITTINGS - ZESTON, INC.

CERTAINTEEd/St. GOBAIN FitTIngS - CertainteEd/St. GOBAIN

5.4 INSULATING CEMENTS

CELOTEX - MN-50 CEMENT

KEENE CORP. - SUPERPONERHOUSE CEMEN'T

P. K. INSUL, MFG. CO. - QUIK-COTE

5.5 ELASTOMERIC MASTICS (VAPOR BARRIER)

FOSTER DIV. OF AMCHEM PRODUCTS - MONOLAR 60-36 (WHTTE)

5.6 SEALANTS

PORTER PAINT CO. FLASHING INSULMASTIC 4010

5.7 FASTENING MATERIALS

$5.7 .1:$ STAPLES

1/2" LEG LENGTH MONEL OUTWARD CLINCH TYPE .050" WIDE $X$ .019" THICK.

5.7 .2 WIRE

MONEL, SOFT ANNEALED, 16 Ga.

$5: 7.3$ BANDING

304 STAINLESS STEEL, 5/8"IIDE X .015" THICK A. J. GERRARD CO.

5.7 .4 TAPE (SHELL - WHITE)

DU- $L L L$ TAPE - ZESTON, INC.

CERTAINTEED TAPE - CERTAINTEED/STI. GOBAIN 
THE DOW CHEMICAL COMPANY

ENGINEERING PRACTICES

INSULATION

$M 8 A-401$

Page 1 of 2

APPLICATION OF RIGID INSULATION ON PIPE

(High Temperature)

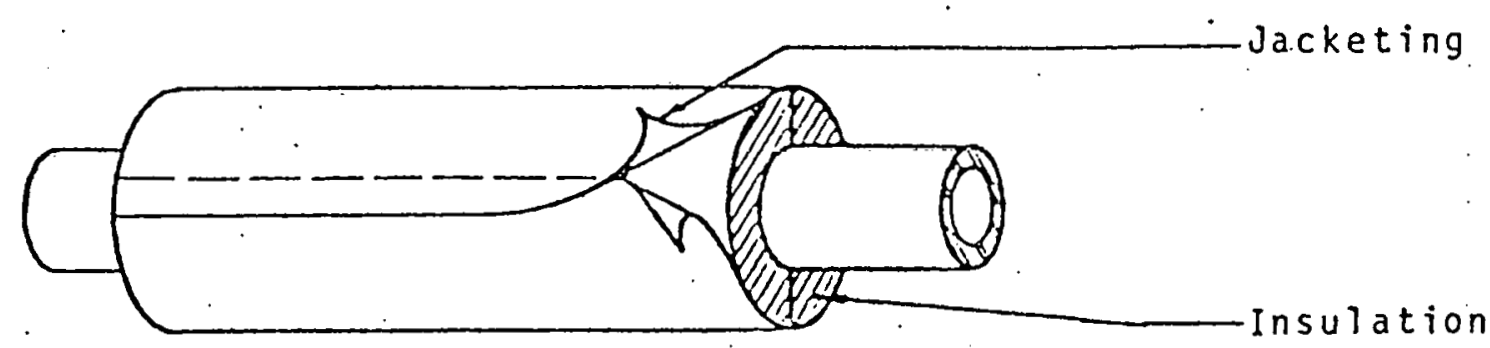

SINGLE LAYER

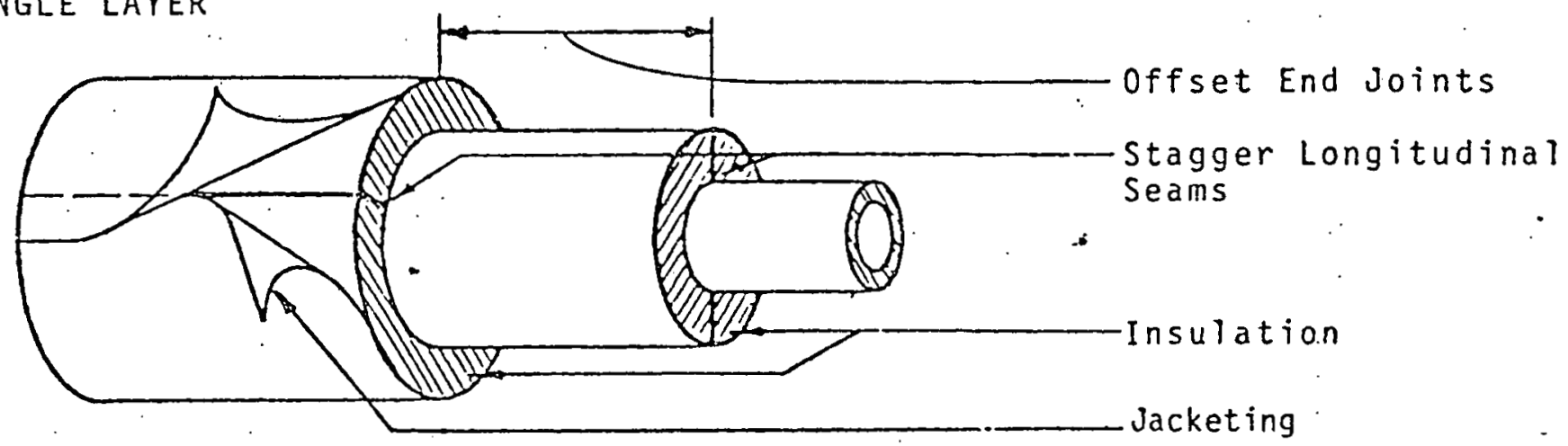

DOUBLE LAYER

APPLICATION NOTES

1. For materials see Project Specifications.

2. Insulation shall be applied over a clean, dry surface. Joints shall be closely butted and all voids filled with insulating cement.

3. Single Layer

3.1 Up to 12" dia. pipe Fasten Sections with wire.

3.2 Over 12" dia. pipe Fasten sections or segments with bands.

4. Double Layer

4.1 Up to 8" dia. pipe Fasten inner \& outer layers with wire. 
THE DOW CHEMICAL COMPANY

ENGINEERING PRACTICES

INSULATION
$M 8 A-401$

Page 2 of 2
4.2 Over 8". dia. pipe
Fasten inner layer with wire and sections or segments of outer layer with bands.

5. All wiring or banding shall be on approximately $q^{\prime \prime}$ centers, using a minimum of 4 loops per $3 \mathrm{ft}$. length. of insulation.

$\rightarrow$ 6. Mechanical Contractor will install hard block insulation complete with jacketing at all hangers, same thickness as specified in pipe line schedule.

Design Notes (Not part of project specifications)

1.0 This practice should be used prinarily for the application of Calcium Silicate, Rigid Insulation. 
IIISULATION

APPLICATION OF WEATHERPROOF JACKETING ON

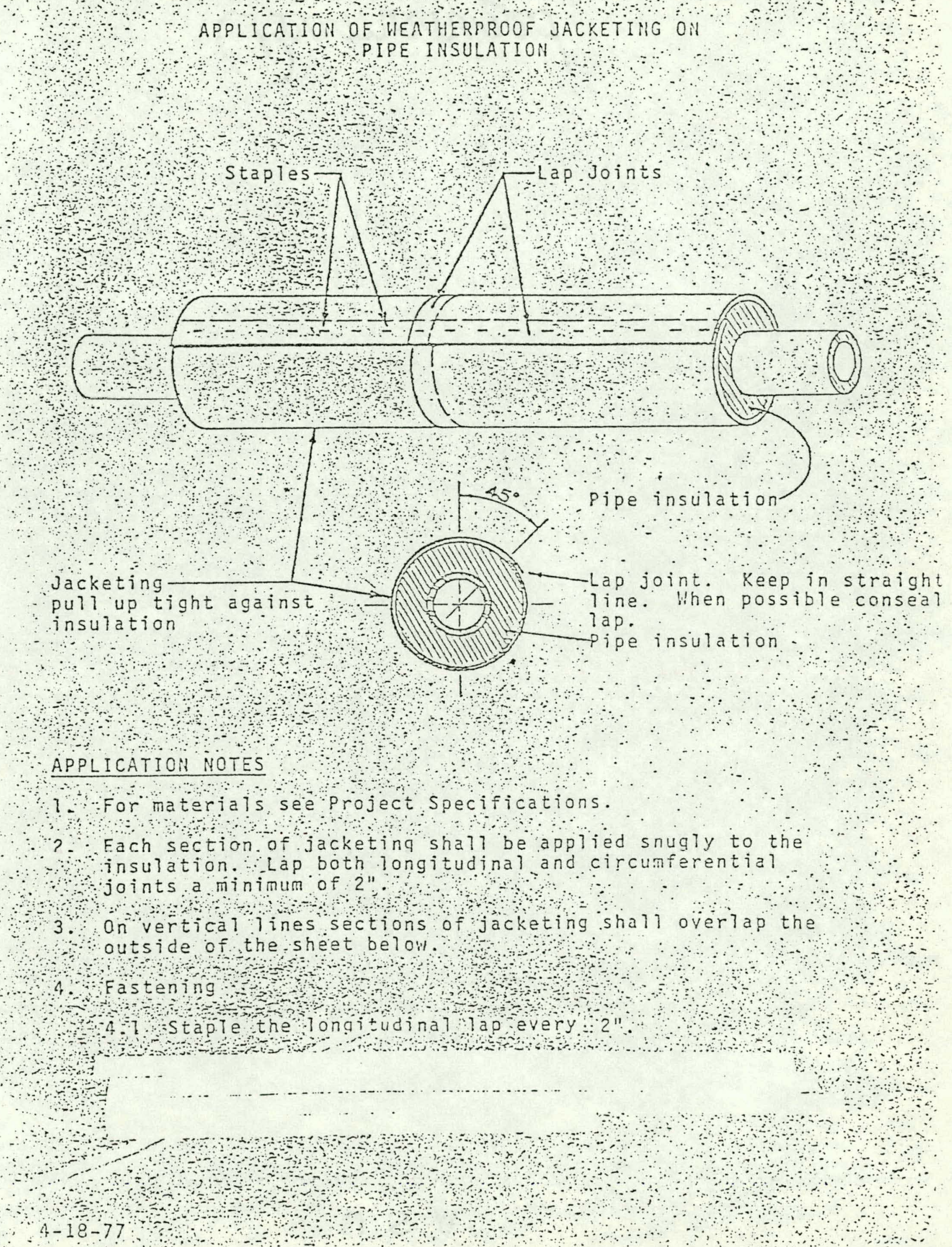


THE DOH CHEMICAL COMPAHY

\section{EMGINEERIMG PRACTICES}

INSULATION

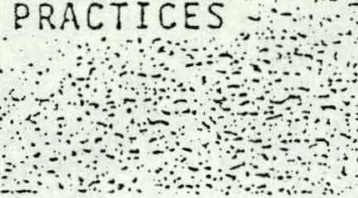

10

S
Page 2 of 250 (MOO.)

$\because \cdots$

A-2 Longitudinaland circumferential joints shall be taped after stapling, use weatherproofing tape that matches the jacketing beirg used Refer to manufacturers

Titerature for specific application instructions and allowable installation temperature ranges.

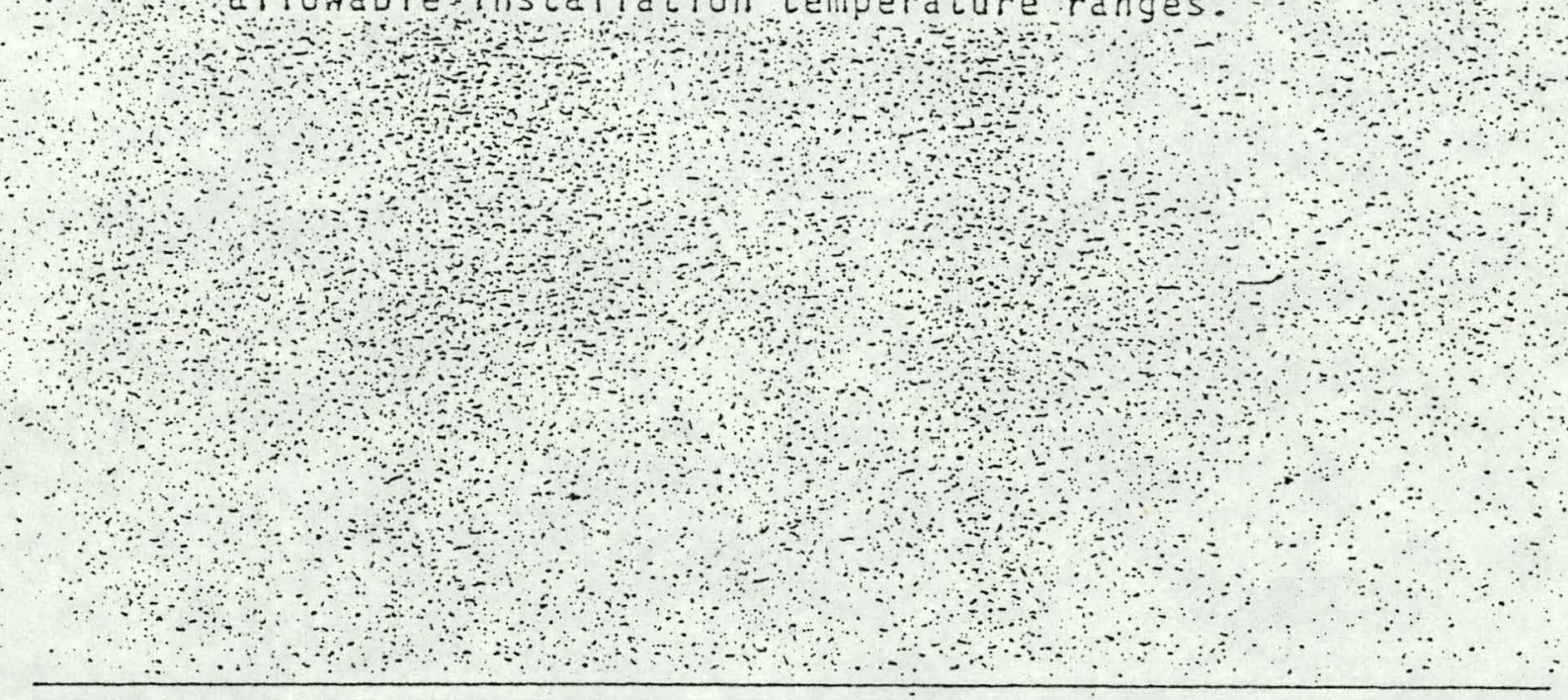

\section{DESIGN NOTES}

(Not part of Próject specifications)

1. See specific weatherproof material practices for a particular products generál use and limitations. 

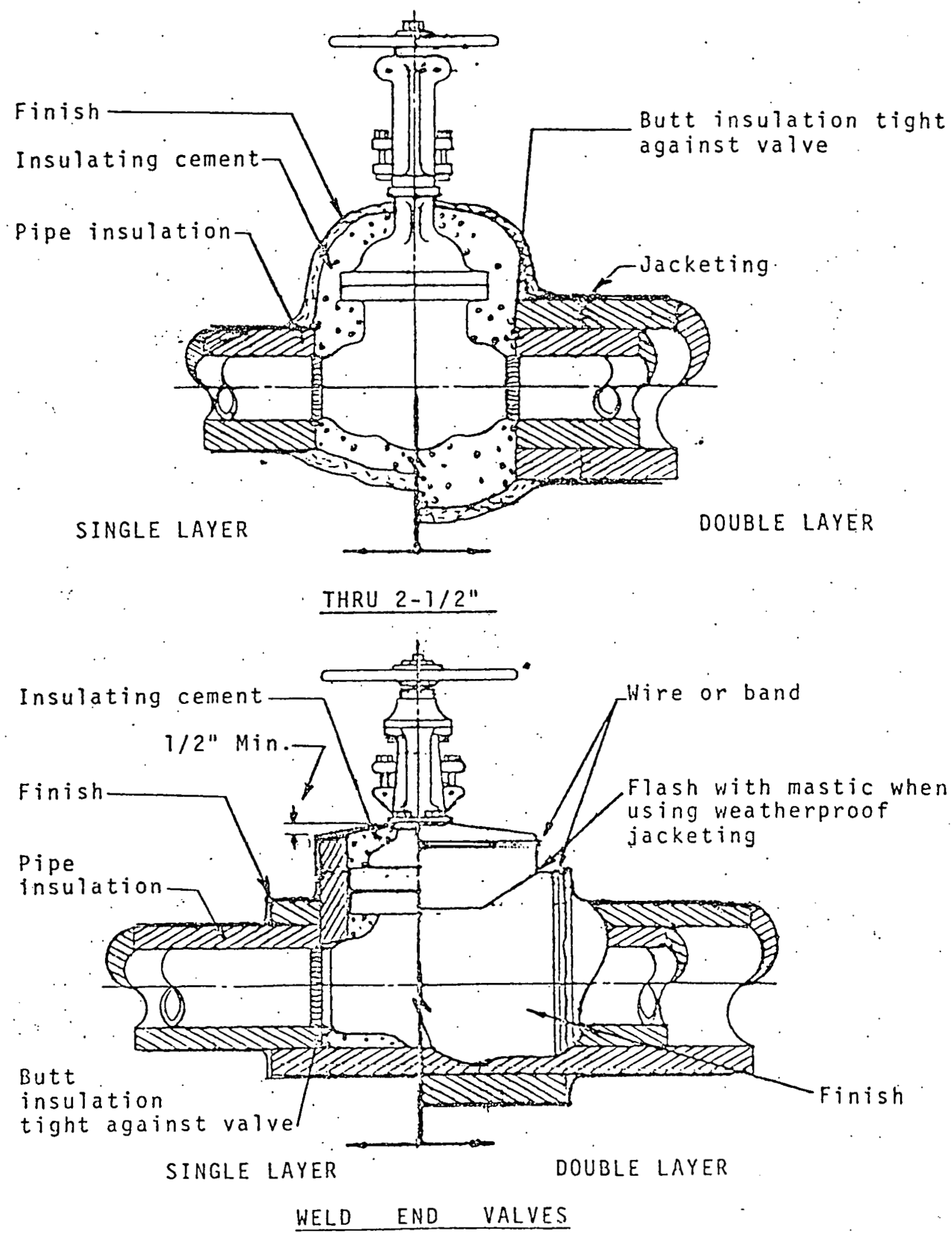

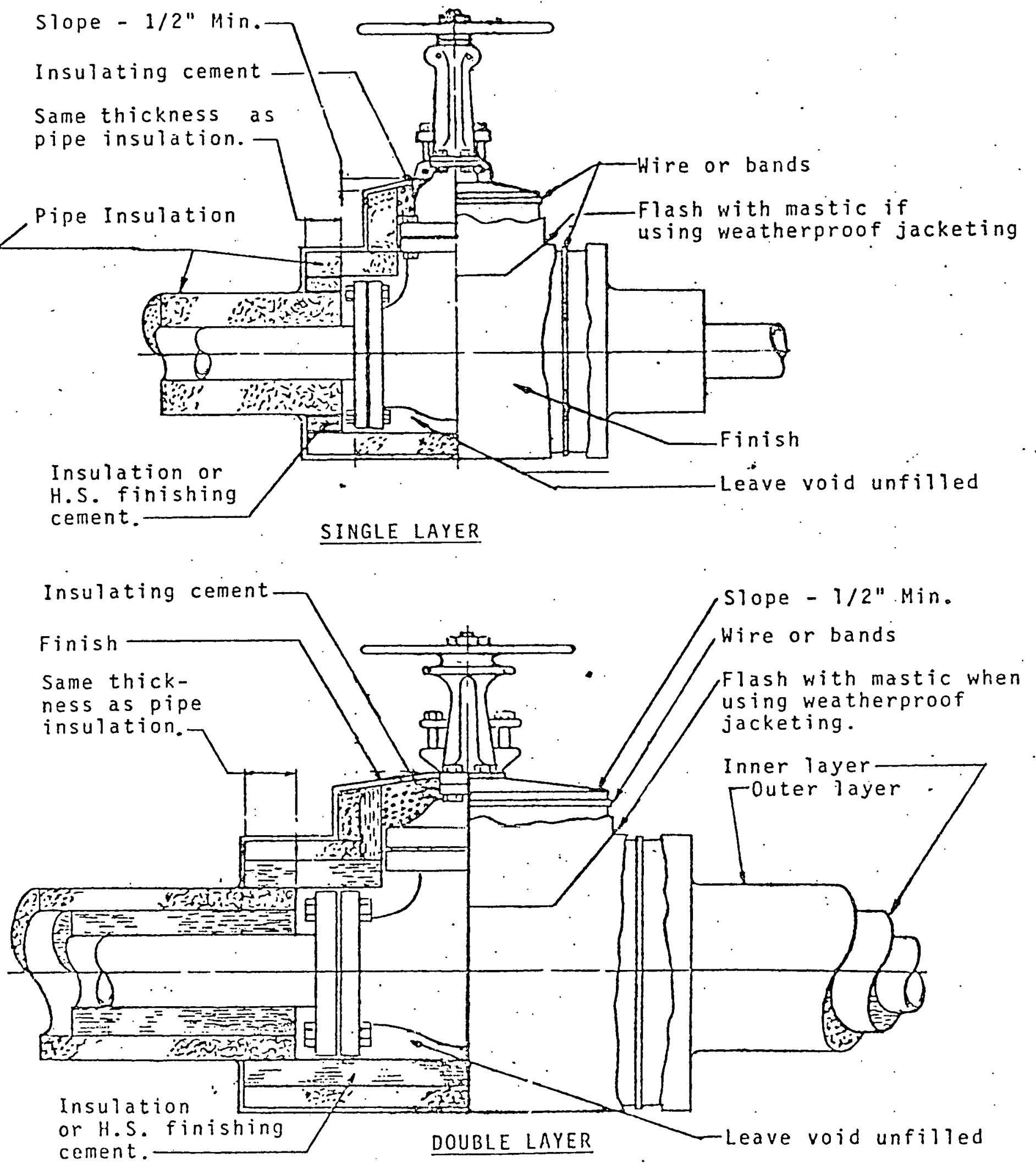

FLANGED VALVES 


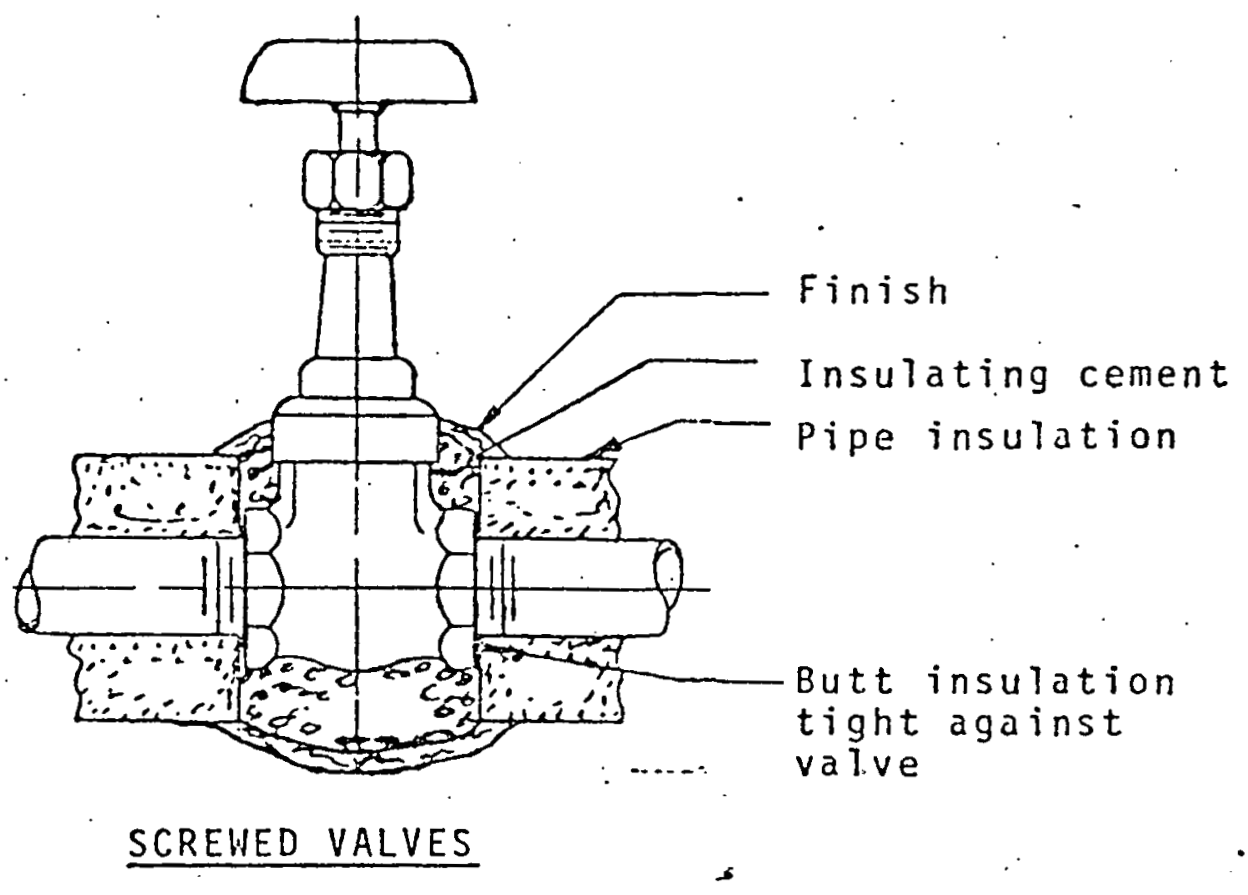

\section{APPLICATION NOTES}

1. For materials see project Specifications.

2. Mitered or sectional blocks of insulation shall be of the same material as adjacent pipe insulation and installed as shown. on sketch.

3. Spot insulating cement to valve as shown, appiying approximately same thickness as adjoining pipe insulation.

4. Fasten mitered or sectional blocks across valve body securely as follows:

4.1 Single-Layer, thru 10" valves: Fasten with wire.

4.2 Single Layer, 12 " valves and over: Fasten with Bands.

4.3 Double Layer, thru 10" valves: Fasten inner and outer layers with wire.

4.4 Double Layer, 12" valves and over: Fasten inner layer with wire and outer layer with bands.

5. Bonnets

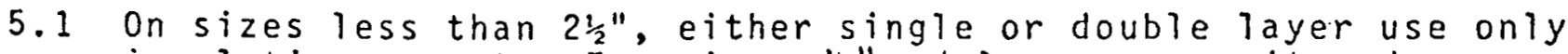
insulating cement. For sizes $Z^{1 / 2} z^{\prime \prime}$ and larger use mitered or sectional blocks. The thickness of either shall be equal to the adjoining pipe insulatiun. 
5.2 Single Layer - Insulate all bonnets operating above $350^{\circ} \mathrm{F}$.

5.3 Double Layer - Insulate all bonnets.

6. Alternate insulation - All sizes:

6.1 Install pre-fabricated insulation fittings of same insulation material \& thickness as on adjacent pipe. Fasten same as above, and point all voids with insulating cement.

DESIGN NOTES (Not part of project Specifications)

1. These application methods are intended to be used with high temperature, rigid type, insulation systems, (above $450 \mathrm{~F}$ ) or as alternates to the pre-cut factory made fittings, such as, Zeston Fittings.

2. This practice should not be used for valves operating below $35^{\circ} \mathrm{F}$. 


\section{APPLICATION OF INSULATION ON FITTINGS}

DOUBLE LAYER

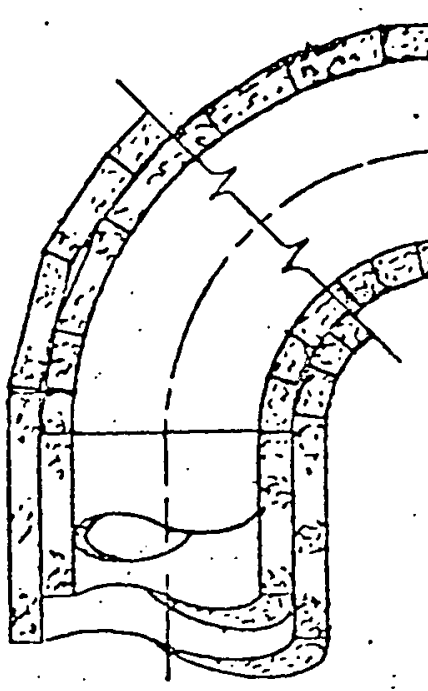

\section{WELDING ELLS 3" AND LARGER}

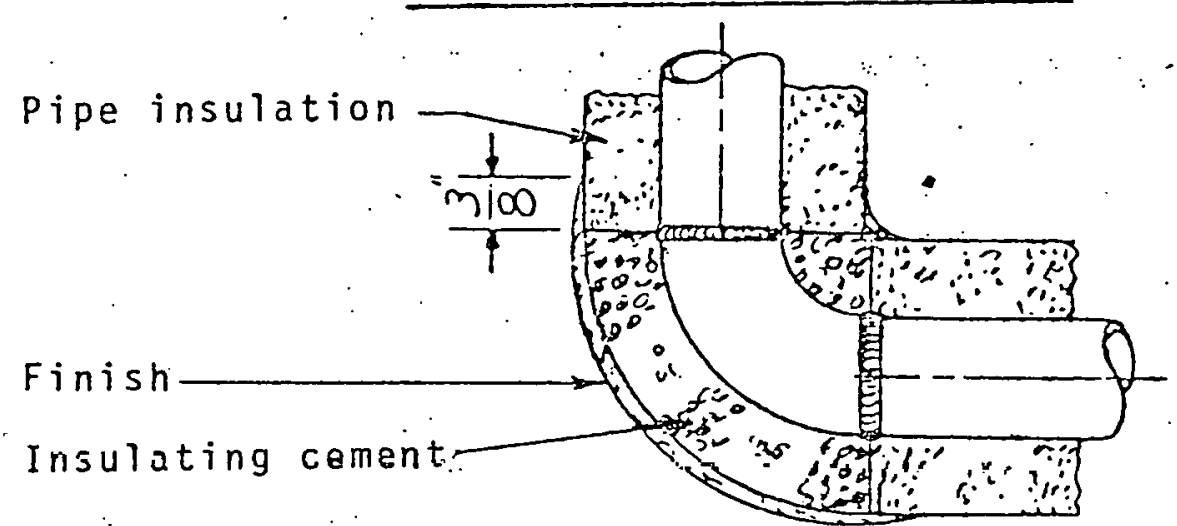

WELDING ELLS THRU 2-7/2"

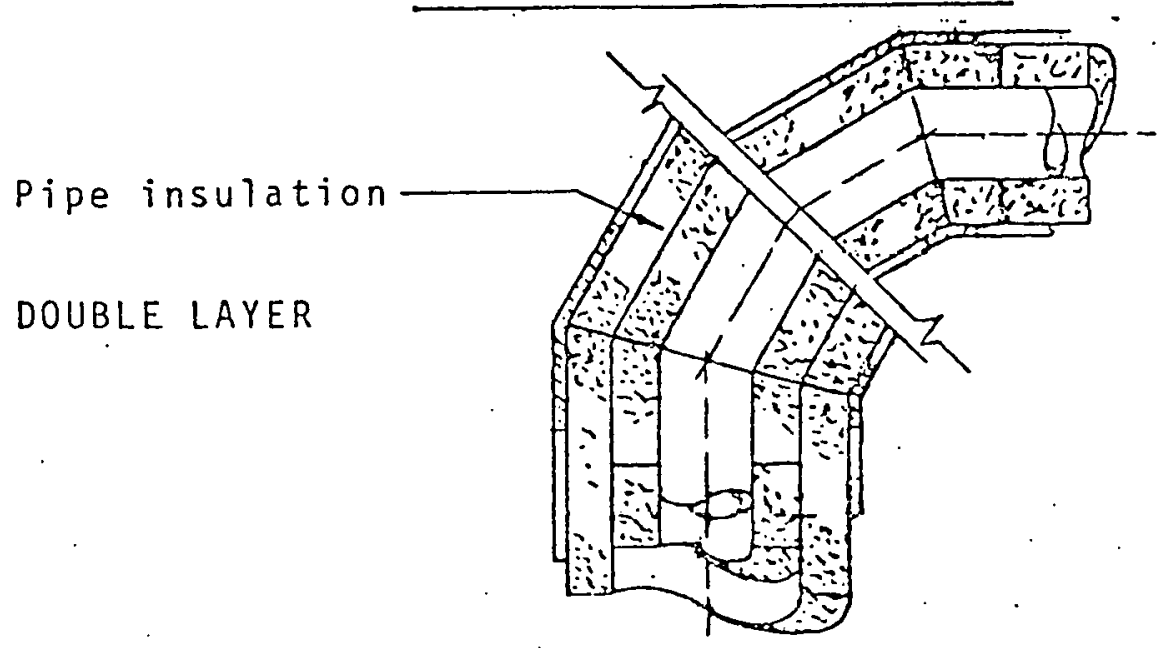

SINGLE LAYER

MITERED ELBOW 


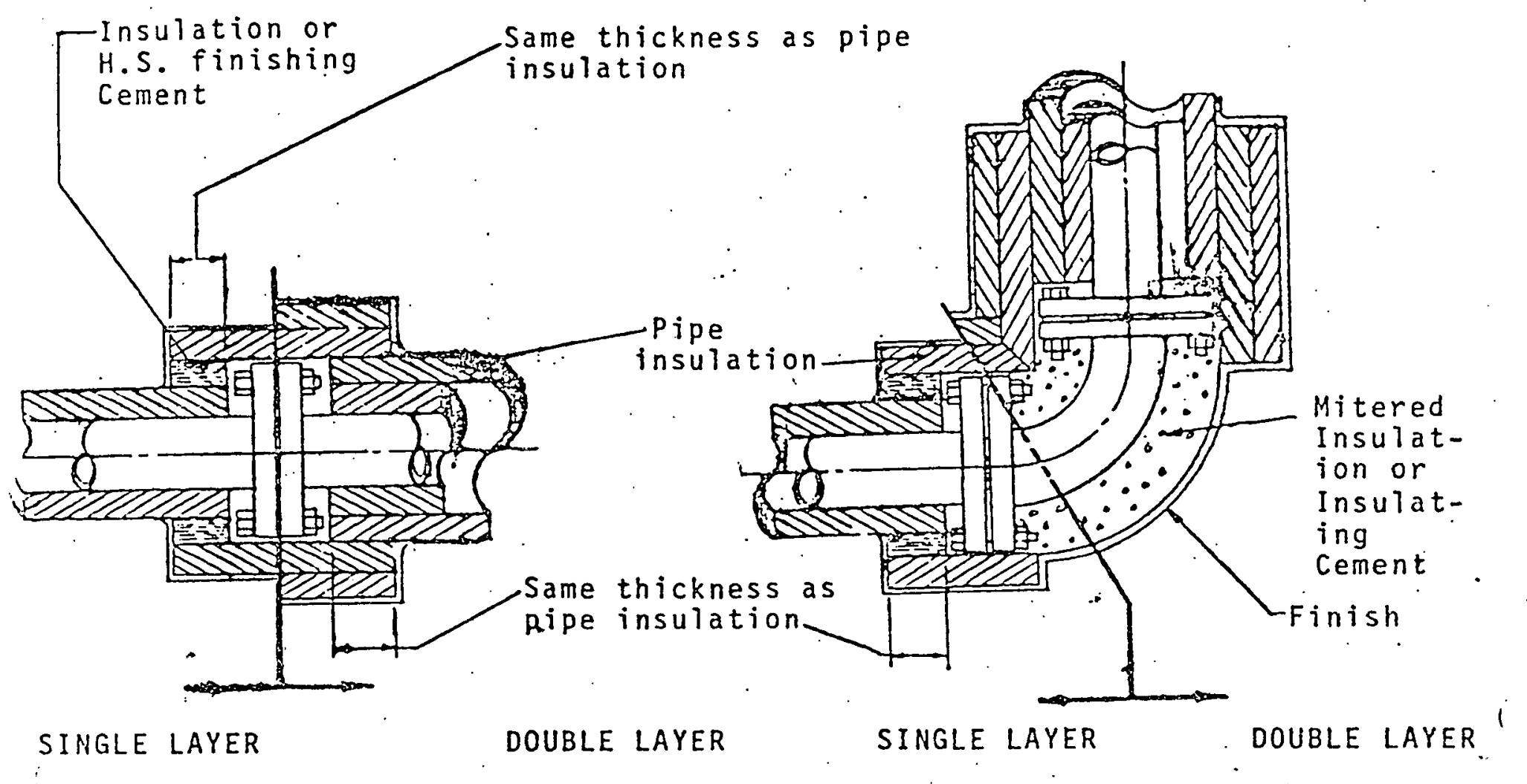

FLANGED UNION

FLANGED ELL 


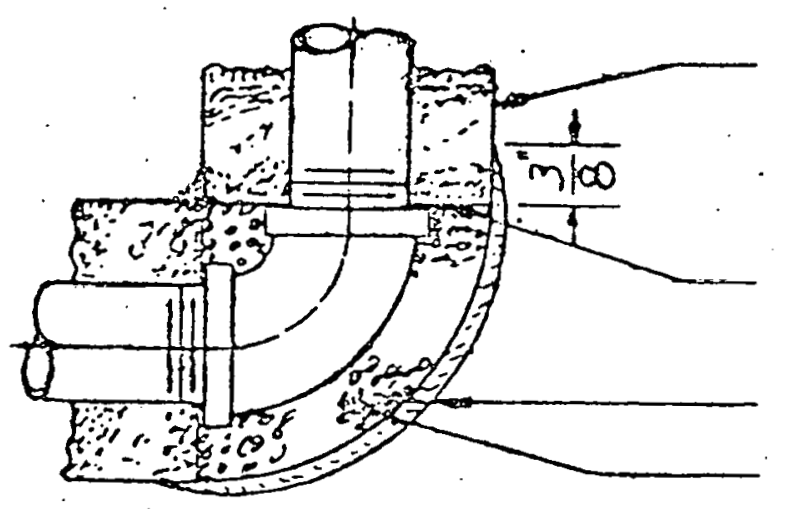

SCREHED ELBOHS
Pipe insulation single or double layer.as specified.

Butt insulation tight against fitting

Finish

Insulating cement

(Screwed tees are similar)

Note: Do not insulate screwed unions unless specified otherwise.

\section{SCREWED FITTINGS}

\section{APPLICATION NOTES}

1. For materials see Project Specifications.

2. Mitered or sectional blocks of insulation shall be of

the same material as adjacent pipe insulation and installed as shown on sketch.

3. Spot insulating cement to fitting as shown, applying approximately same thickness as adjoining pipe insulation.

4. Fasten mitered or sectional blocks on fittings securely as follows:

4.1 Single layer, thru 10": Fasten with wire.

4.2 Single layer, 12" and over: Fasten with bands.

4.3 Double layer, thru 10": Fasten inner and outer layer with wire.

4.4 Double layer, 12" and over: Fasten inner layer with wire and outer layer with bands. 
6. Alternate insulation - all sizes:

6.1 Install pre-fabricated insulation fittings of same insulation material \& thickness as on adjacent pipe. Fasten same as above, and point all voids with insulating cement.

DESIGN NOTES (Not part of Project Specifications)

1. These application methods are intended to be used with high temperature, rigid type, insulation systems, (above $450^{\circ} \mathrm{F}$ ) or as alternates to the pre-cut factory made fittings, such as, Zeston Fittings.

2. This practice should not be used for fittings operating below $35^{\circ} \mathrm{F}$. 
THE DOW CHEMICAL COMPANY

DOU ENGLEERRING SPECIFICATION

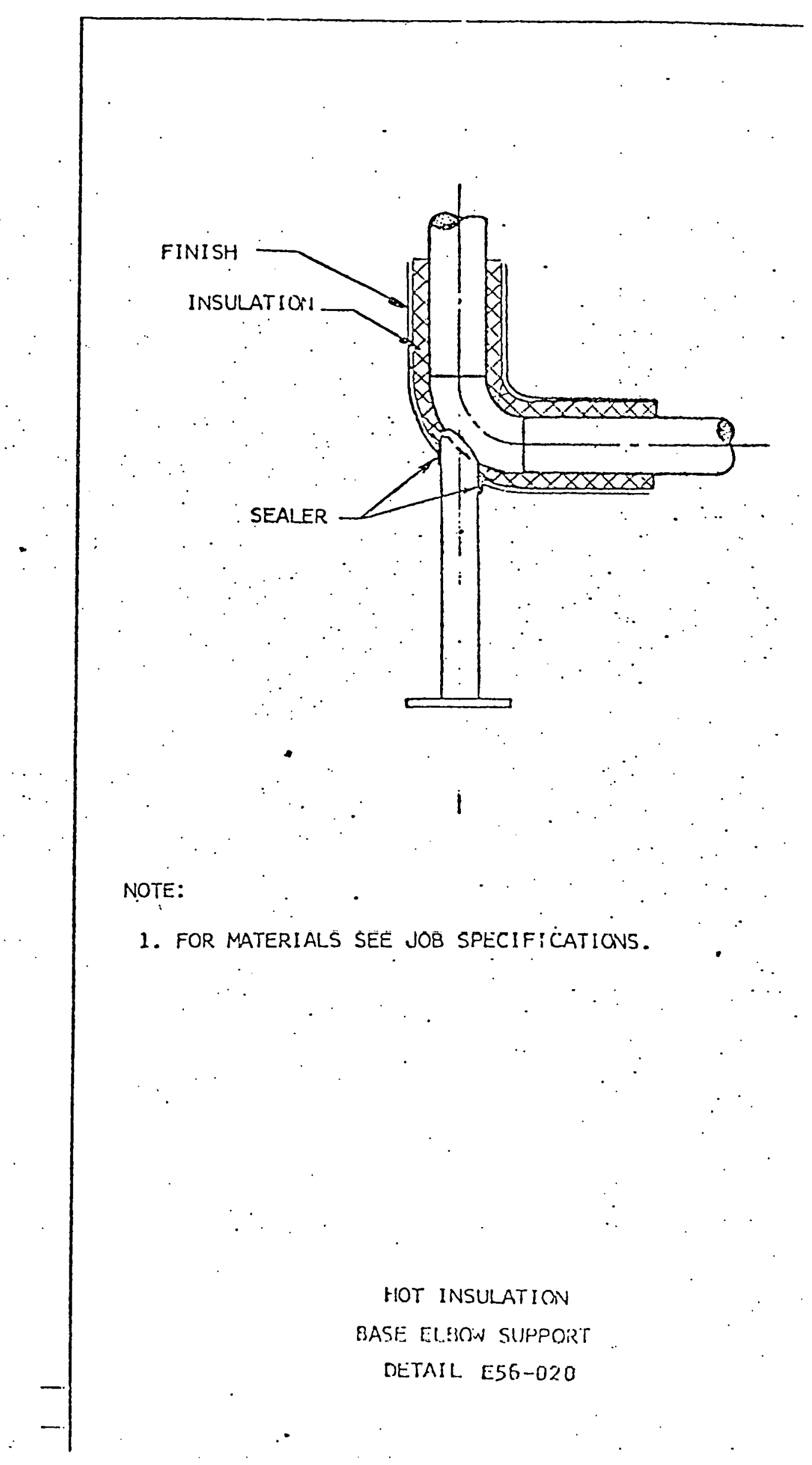


THE DOH CHEHICAL COMPANY DO"' ENGLNEERING SPECIFICATION

HOT INSULATION $\therefore$ DUIMY LEG PIPE SUPPORT

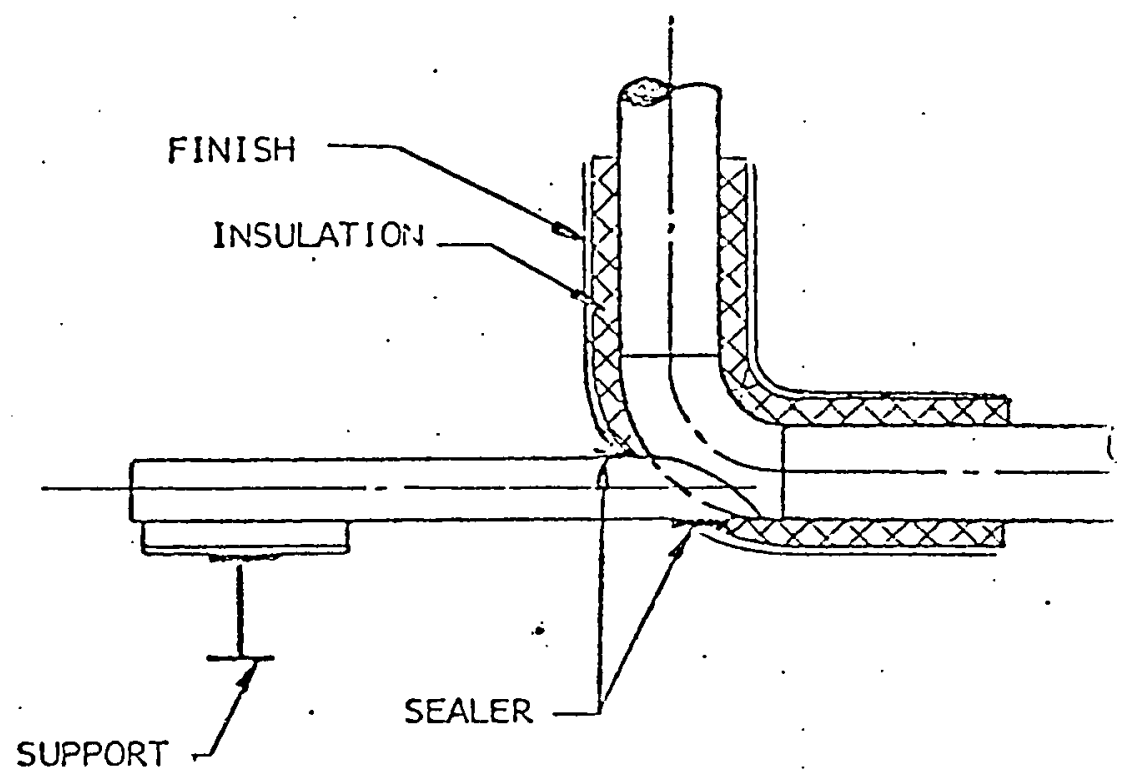

NOTE:

1. FOR MATERIALS SEE JOB SPECIFICATIONS. 
E DOH CHEMICAL COMPANY

HOT INSULATION.

$|-2| 2-6 \mid$

EENGLEERING SPECIFICATION DETAIL AT SHALL SCREWED OR MELDED FITTINGS

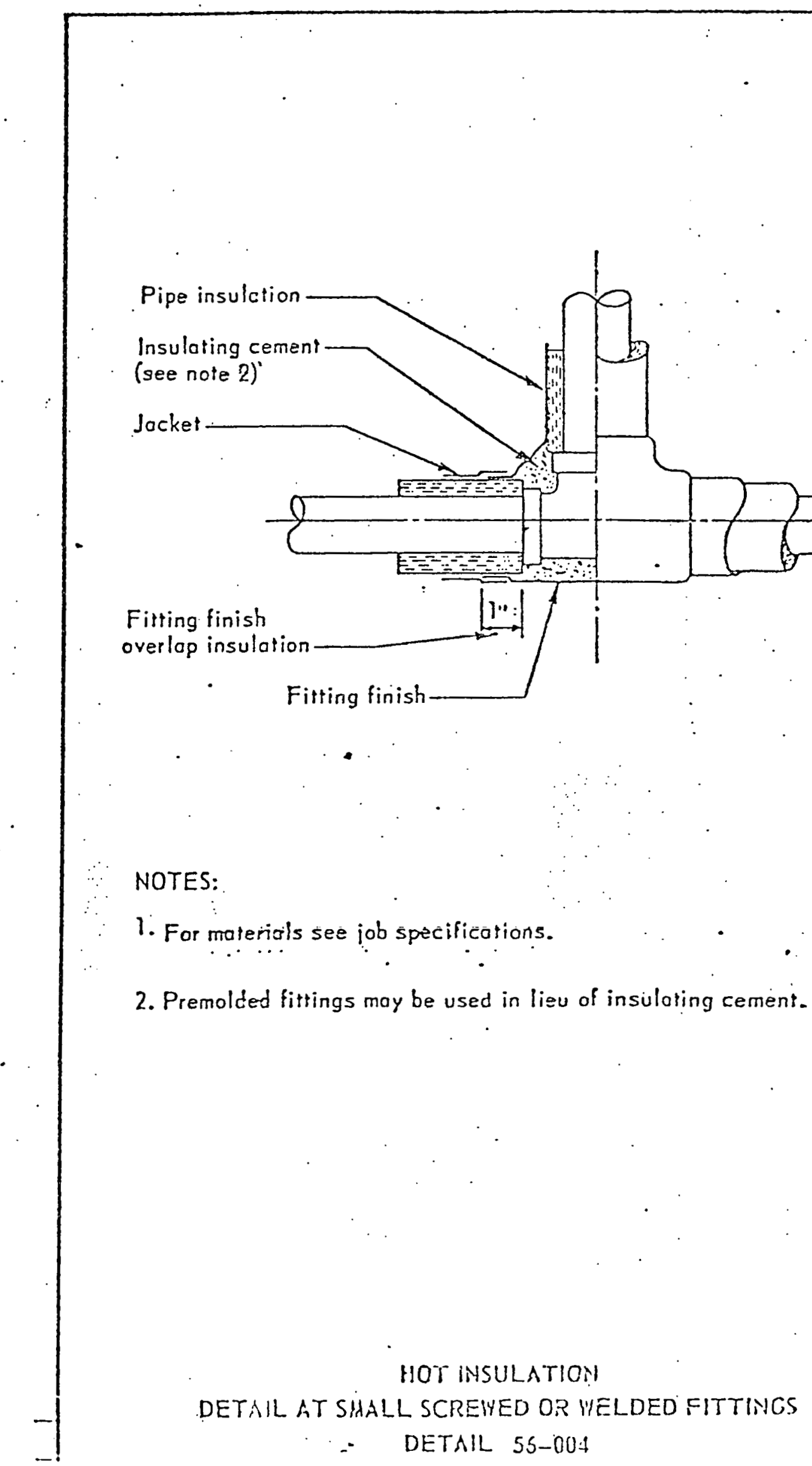


U.S. Department of Energy

Solar Steam Generation
FOSTER WHEELER ENERGY CORP.

FWEC Contract 11-60863

JOB SPECIFICATION NO. 60863-83A1

\section{PAINTING}

The subject specification is issued herewith per index of pages noted below. If this is a later revision than now in your possession, please destroy superseded pages and insert the revised pages.

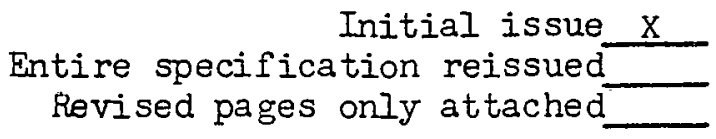

\section{REVISION INDEX}

\begin{tabular}{cll} 
Page & Rev. & Date \\
\hline 1 & 0 & $8 / 26 / 76$ \\
2 & 0 & $8 / 26 / 76$ \\
3 & 0 & $8 / 26 / 76$ \\
4 & 0 & $8 / 26 / 76$ \\
5 & 0 & $8 / 26 / 76$ \\
6 & 0 & $8 / 26 / 76$ \\
7 & 0 & $8 / 26 / 76$ \\
8 & 0 & $8 / 26 / 76$ \\
9 & 0 & $8 / 26 / 76$ \\
10 & 0 & $8 / 26 / 76$ \\
11 & 0 & $8 / 26 / 76$ \\
12 & 0 & $8 / 26 / 76$
\end{tabular}

* Pages revised for this issue are noted by asterisk.

Issue No. 1 Date 4/25/79

Basis:

Dow Chemiral. ro. Specification 


\subsection{PAINTING}

18.1 Scope

18.1.1 The Contractor shall furnish all supervision, labor, materials (including paints, thinners, cleaners, and sandblast sand), tools, compressed air, scaffolding, and equipment necessary to satisfactorily complete the work as defined in these specifications and by the drawings and equipment list.

\subsection{Structural and Miscellaneous Steel}

18.2.1 The term, "structural and miscellaneous steel", as used herein, includes steel structures (ladders and platforms) and all manner of supports for piping, instrumentation, and electrical work. Miscellaneous pipe and instrument supports are not all shown on drawings.

18.2.2 Owner furnished structural steel (ladders and platforms) and miscellaneous Contractor furnished steel will be primer coated in accordance with Dow Engineering Specification $57-247$.

18.2.3 Grating shall be galvanized per Dow Standard 57-270.

18.2.4 Galvanized coatings, if damaged prior to or during erection, shall be repaired in accordance with Dow Engineering Specification 57-271.

\subsection{Piping}

18.3.1 Carbon steel piping, not to be insulated, with an operating temperature of $250^{\circ} \mathrm{F}$ or less; and steel piping that will be insulated for personnel protection only (indicated by symbol "*" on line schedule), shall be painted as follows.

18.3.1.1 Sandblast to near white metal, NACE No. 2 surface finish, and prime with inorganic zinc in accordance with Dow Engineering Specification E57-247.

18.3.1.2 Valves shall be hand or power tool cleaned to remove all dirt, dust, grease, rust, loose paint, and/or other foreign material, and primed with inorganic zinc primer in accordance with Dow Engineering Specification E57-247.

18.3.1.3 Primed piping shall be spot primed after erection, and painted in accordance with Dow Engineering Specification E57-223. 
18.0 PAINTING (CONTINUED)

18.3 Piping (Continued)

18.3.5 Carbon steel piping to be insulated, having an operating temperature above $250^{\circ} \mathrm{F}$, will not require sandblasting and painting.

18.3.6 Surfaces of heat traced piping that will be covered with insulation shall be sandblasted and primed per details of Paragraph 12.3.1.1. The primed piping, including valves, shall be spot primed with inorganic zinc after erection. No further painting will be required.

18.4 Safety Shower and Eyewash Installations

18.4.1 Galvanized surfaces shall be cleaned and phosphatized as follows:

Galvanized surfaces shall be cleaned with chlorothene to remove any residual oil or grease and phosphatized with a ten per cent solution of phosphoric acid in water applied to the galvanized surfaces. The surfaces shall be kept wet or damp with the acid solution until a matte (dull) finish is formed, and then shall be rinsed with clean water to remove all zinc salts. Surfaces shall be allowed to dry thoroughly before being painted.

18.4.2 Safety shower and eyewash installations shall be painted with alkyd paint in accordance with Dow Specification E57-223. The color scheme to be as specified by Owner's representative.

\subsection{Carbon Steel Surfaces of Owner Furnished Vesse]s}

18.5.1 Unless otherwise specified on equipment drawings, these items will be furnished primed with inorganic zinc $(57-247)$.

18.5.2 Dirt, dust, grease, oil, rust, or other foreign matter shall be removed before painting.

18.5.3 The exposed primed surfaces of vessels that are not to be insulated, including the inside surface of vessel skirts, shall be spot primed with inorganic zinc and painted with alkyd paint in accordance with Dow Engineering Specificatiun E57-223.

18.5.4 Surfaces shall be spot primed with inorganic zinc after erection of vessels which will be insulated.

JWC 


\subsection{PAINTING (CONTINUED)}

18.6 Exposed metal surfaces of field instruments and electrical devices. Caution -- protect vents, glass, valve stems, threads, etc. Do not plug vent holes. Do not paint valve stems.

18.6.1 Iron and steel surfaces shall be cleaned and painted in accordance with Dow Engineering Specification E57-223.

18.7 Touch-up of existing painted surfaces marred by work on this contract.

18.7.1 All foreign matter shall be removed and the marred surfaces shail be painted to match the existing paint system.

18.8 The following surfaces will not require field painting:

18.8.1 Concrete.

18.8.2 Galvanized steel grating.

18.8.3 Galvanized steel piping, except for safety shower and eyewash installations.

18.8.4 Stainless steel surfaces, except surfaces, to be insulated.

18.8.5. Surfaces of steam lines (? ine number prefixed by $S$ ) that will be covered with insulation, including steam traps and steam trap drain piping.

18.8.6. Insulation.

18.8.7 Vendor furnished equipment with shop finished paint systems such as pumps, motors, etc., except where touch-up of marred surfaces is required.

18.8.8 Cable tray.

18.8.9 Switchgear and instruments inside buildings.

18.8.10 Transformers, electrical switches, and switchgear.

18.8.11 Instruments, instrument cases, and vendor finished panel boards.

18.8.12 Electrical switch boxes.

18.8.13 Plastic surfaces. 
18.0 PAINTING (CONTINUED)

18.9 Paint Materials

18.9.1 Paint materials shall be delivered to the job site in original unopened containers with labels attached.

18.9.2 Paint materials shall be adequately stored and protected against freezing or deterioration.

18.10 Application

18.10.1 Surface preparation and priming should normally be performed prior to installation or erection, with completion of the painting after erection. However, where it is advantageous to do so, some or all of the finish painting may also be performed prior to installation or erection. In such cases, damaged areas of primer and paint shall be spot primed and/or spot painted after installation or erection so that, when completed, painted surfaces shall have the number of coats and total film thickness specified.

18.10.2 Paint shall be applied only to clean, dry, non-contaminated surfaces.

18.10.3 Damaged areas of primer shall be cleaned and spot primed in accordance with the paint system specified before the items are insulated or painted out.

18.10.4 Burned or otherwise damaged galvanizing shall be repaired in accordance with Dow Engineering Specification 57-27i.

18.10.5 Sufficient signs to convey adequate information, such as spray painting, men working overhead, no smoking, sandblasting, or similar signs where applicable shall be furnished and posted at work areas.

18.10.6 Reasonable care shall be exercised in spraying paints that contain volatile and/or flammable solvents. No welding, sparks, or open flame shall be in the immediate area.

18.10.7 Materials, scaffolds, and equipment shall not be left in the way of plant operation activities. Ladders, pencil boards, scaffolds, and similar items, if left in place, shall be securely tied.

18.10.8 . Sand and debris shall be kept out of sumps, drains, sewer lines, drainage ditches, trenches, and similar places.

J!IC PAINTING

SECTION 18

S104-E270003

$8 / 26 / 76$ 


\subsection{PAINTING (CONTINUED)}

\subsection{Application (Continued)}

18.10.9 Paint skimmings and cleaning solvents shall be collected and removed to disposal grounds. Dumping these materials on the ground, in ditches, or in sewers will not be permitted.

18.10.10 Paint misplaced on items that are not to be painted, or on items which are to be finished a different color, shall be promptly removed by the Contractor, leaving the surface clean, unstained, and undamaged. On painted items, the Contractor will have an option of removing the misplaced paint or painting over same, furnishing labor and materials, leaving a neat appearance satisfactory to the Owner's representative.

18.10.11 Protect bearings, mechanical equipment, instruments, switchgear, etc. from damage by sand and sandblasting operations.

18.10.12 Valve stems, packing gland bolt threads, pump and motor shafts, sprinkler heads and actuating devices, instruments, glass surfaces, and other similar items shall not be painted. Such items shall be protected or the paint removed by the Contractor, leaving the surface undamaged. Hot surfaces such as light fixtures and similar items shall. be protected from paint with non-combustible materials.

18.10.13 Painting shall be done only when weather conditions permit the surface to be free from moisture and above the manufacturer's minimum temperature requirements.

18.10.14 Reasonable caution shall be exercised to avoid painting immediately prior to rain.

18.10.15 Each coat of paint, except where specified otherwise, shall be a full coat.

18.10.16 Spot coats of first coat primer shall cover exposed bare (unpainted) metal surfaces.

18.10.17 Subsequent spot coats of paint shall completely cover previous spot coats. 


\subsection{PAINTING (CONTINUED)}

\subsection{Application (Continued)}

18.10.18 Minimum film thicknesses specified are the minimum acceptable dry film thicknesses of each paint, or paint system, as determined by measurement on a flat surface. with a mikrotest film thickness gage, as manufactured by the Nordson Corporation or Owner approved equal. Areas in any coat of paint which are determined by measurement to be less than the minimum dry thickness specified shall have sufficient paint added to attain the specified dry thickness.

18.10.19 Spray painting shall not be done where overspray and/or drips cannot be controlled.

18.10.20 Mixing, thinning, and application shall be done in accordance with the paint manufacturer's written instructions and these specifications.

18.10.21 Overspray, skips, sags, runs, drips, and holidays shall kept to a minimum. Additional coats shall be applied to holidays and thin areas to bring them up to specifications at no extra cost to the owner.

18.10.22 Colors shall be cut in a neat, straight 7 ine where two colors meet.

18.11 The finish colors shall conform to the existing plant color scheme. The Owner's representative will designate color coding scheme. 
THE DO'Y CHEHICAL COHPANY DOW ENGINEERING SPECIFICA TION
PROTECTIVE COATINGS

SILICONE-ALKYO

Maximum Temperature: Dry $300^{\circ} \mathrm{F}$

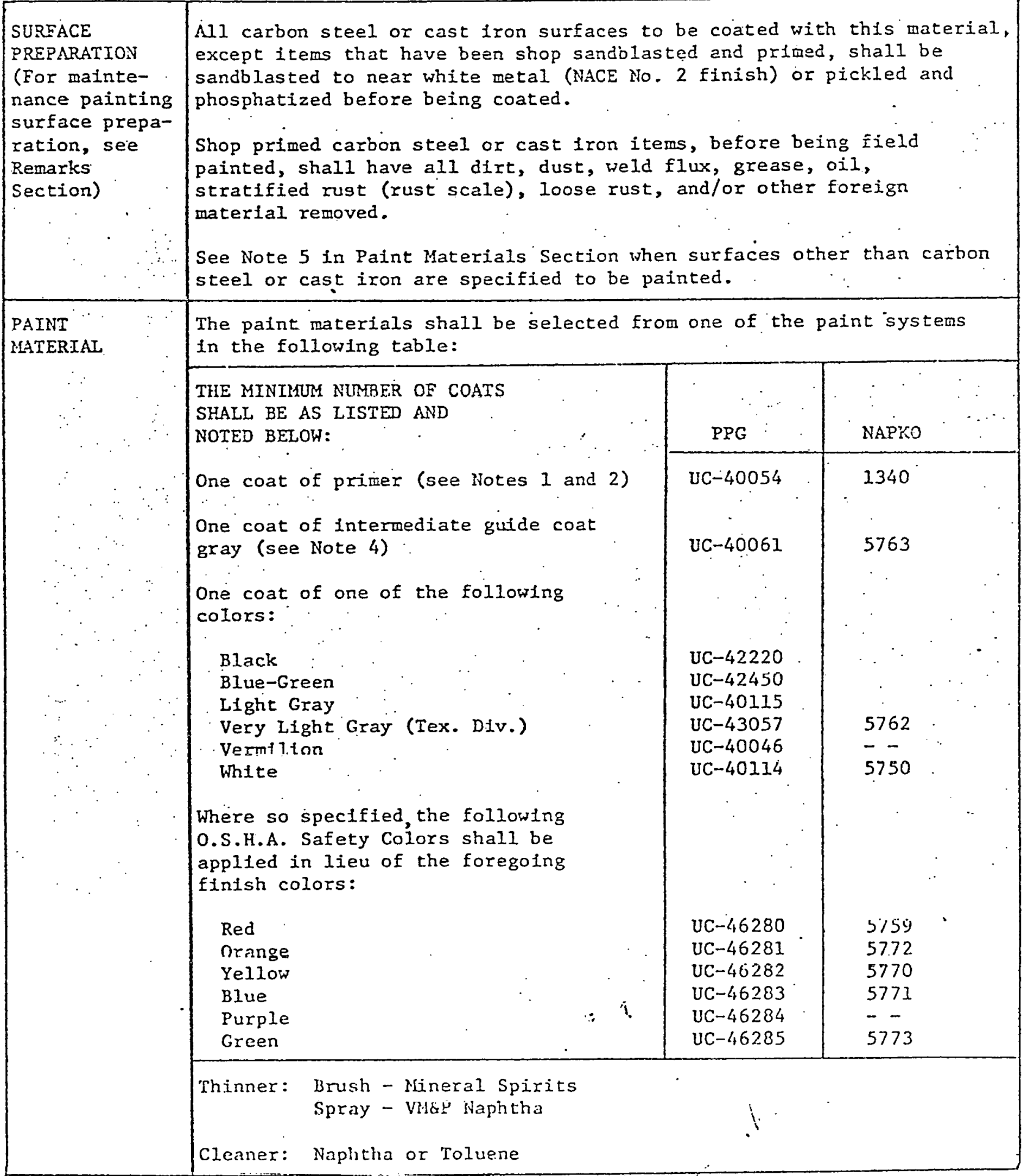


THE DOH CHEHICAL COHPANY

Page 2 of 4

DOM ENGINEERING SPECIFICATION

PAINT

MATERIALS

(Continued)

\section{Notes:}

1. Primed Steel: In field one spot coat of silicone-alkyd primer shall be applied in lieu of a full coat, except items primed with inorganic zinc, or galvanized and phosphatized, shall have a spot coat of inorganic zinc applied before applying a gulde coat of PPG Aquapon and finish coat of silicone-alkyd.

2. Over vendor finish paint one coat of PPG multiprime or Napko 1340 shall be applied in lieu of the silicone-alkyd primer before applying the guide and finish coats of silicone-alkyd.

3. The color coat shall be omitted from all surfaces that are to be insulated with Class $G, H, J$ or $k$ insulation. All painting shall be omitted from surfaces to be insulated with Class $F$ insulation and hotter and class $L$ insulation and colder.

4. For white color coat, a white guide coat, tinted with one-half pint of gray per gallon of white shall be used.

5. The following surfaces shall be coated only when so specified in the material specifications, the job specifications, or in the purchase order. When these surfaces are specified to be coated, they shall be cleaned and.primed as indicated below before the guide and Einish coats are applied.

TYPE SURFACE

Aluminum
Alloys

SURFACE PREPARATION
Surfaces shall be treated
with Amchem Aladine 1200
or owner-approved equal
chromate conversion
coating. A dull matte
finish is required.
Rinse.
Surfaces shall be treated
with $38 \%$ concentrated HCl,
one gallon to one gallon,
$40 \%$ by weight ferric
chloride. iniwater. A
dull matte finish is
required. Rinse.

PPG 6-204

Zinc chromate PPG UC...40054 (Multiprime) PRIMER . 

PROTZCIIVR CCATING FOR FIELD CUTS ATD WELDS

ON GALVAMIZDD ITEMS

\begin{tabular}{|c|c|}
\hline $\begin{array}{l}\text { Paint } \\
\text { Materials }\end{array}$ & $\begin{array}{l}\text { I heavy coat of ZRC (The Sealube Company, Wakefield, } \\
\text { Massachusetrs) or Galvanox, Type I (Subox, Inc.) } \\
\text { Thinner For ZRC, mineral spirits; for Galvanox, Xylol } \\
\text { Cleaner For.ZRC, kerosene or varsol; for Gslvanox, Xylol. }\end{array}$ \\
\hline $\begin{array}{l}\text { Application } \\
\qquad \\
\because\end{array}$ & 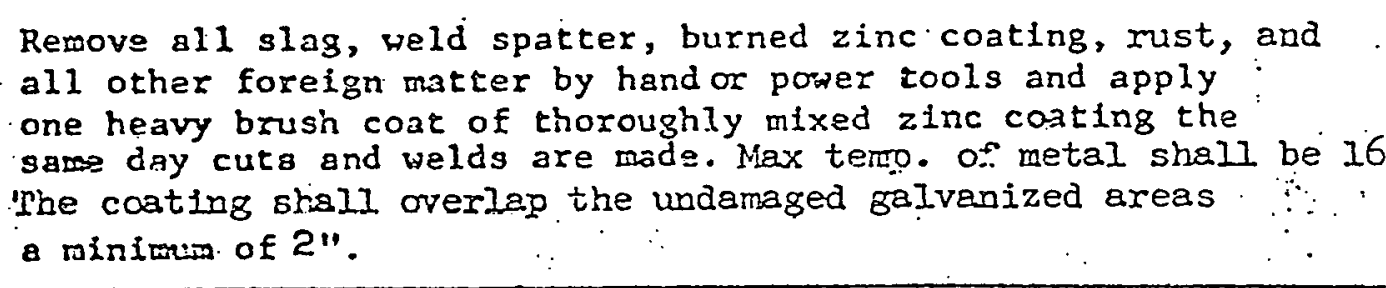 \\
\hline $\begin{array}{l}\text { Film } \\
\text { Thickness }\end{array}$ & $\begin{array}{ll}\text { Het } & 4 \text { mils total, minimut } \\
\text { Approximate coverage } & \begin{array}{l}300 \text { square feet per gallon, or } 12 \\
\text { square feet per pound. }\end{array}\end{array}$ \\
\hline 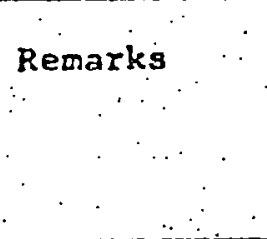 & $\begin{array}{l}\text { Solvents in these materialis are volatile and flamable. } \\
\text { Keep containers closed and away from heat, open flame, or } \\
\text { spark3. } \\
\therefore \\
\therefore \quad\end{array}$ \\
\hline
\end{tabular}




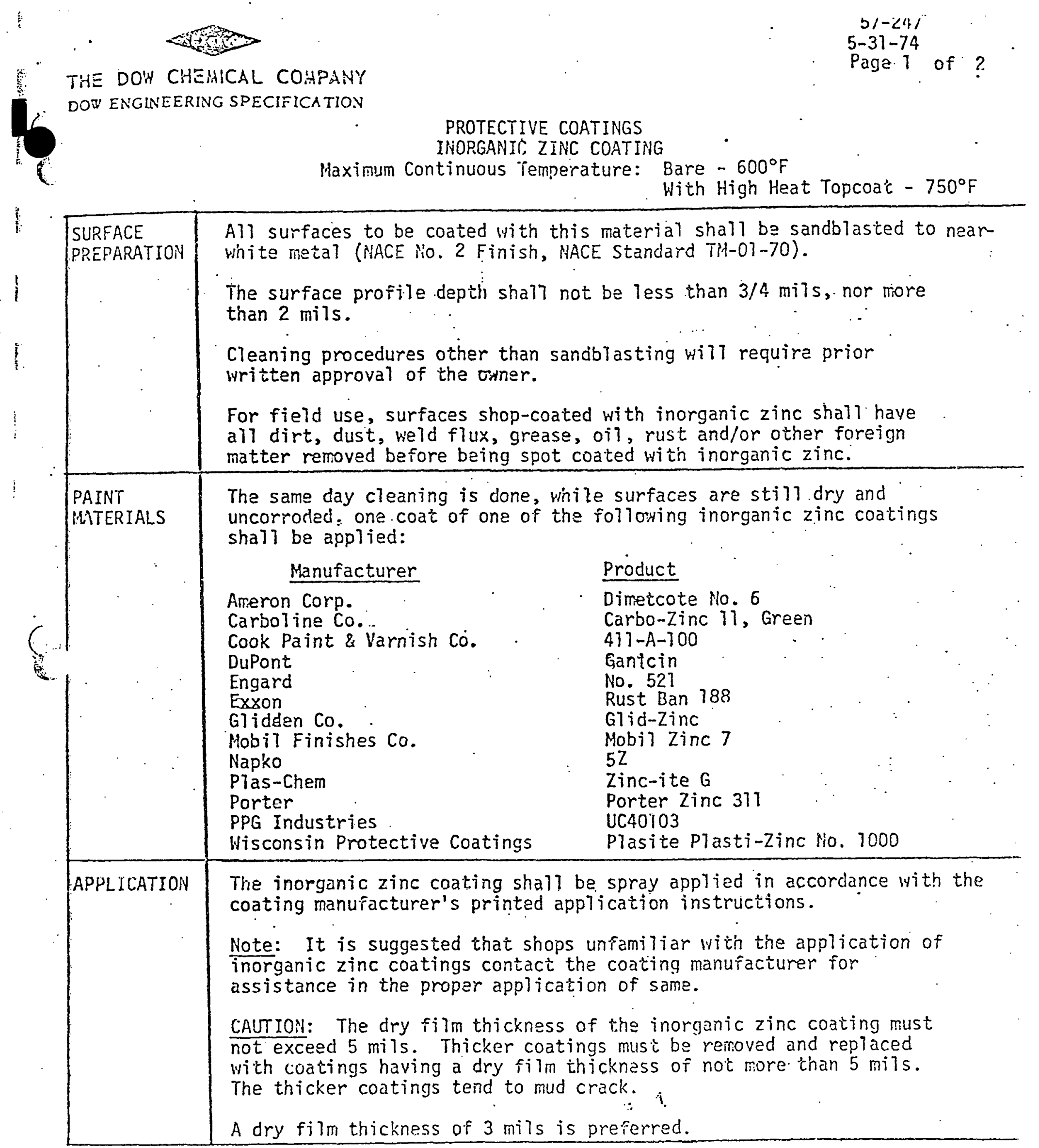




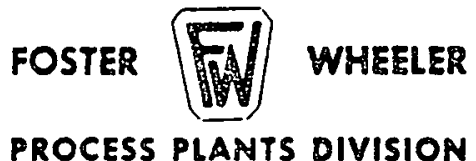

1

2

3

4

5

6

7

8

9

10

11

12

13

14

15

16

17

18
WELDING REQUIREMENTS FOR EQUIPMENT AND PIPING

JOB SPECIFICATION $60863-88 \mathrm{C} 1$

\section{REVISION INOEX}

ENG. STD. $88 \mathrm{C} 1$ INDEX PAGE 1 ISSUE 0

DATE Sep 1, 1978

\section{DATE}

$9 / 1 / 78$

$9 / 1 / 78$

$9 / 1 / 78$

$9 / 1 / 78$

$9 / 1 / 78$

$9 / 1 / 78$

$9 / 1 / 78$

$9 / 9 / 78$

$9 / 1 / 78$

$9 / 1 / 78$

$9 / 1 / 78$

$9 / 1 / 78$

$9 / 1 / 78$

$9 / 1 / 78$

$9 / 1 / 78$

$9 / 1 / 78$

$9 / 1 / 78$

$9 / 1 / 78$

- PAGES REVISED FOR THIS ISSUE ARE NOTEO BY ASTERISK. 
FOSTER WHEELER

PROCESS PLANTS DIYISION
WELDING REQUIREMENTS

FOR EQUIPMENT AND PIPING
ENG STD $88 \mathrm{C} 1$

PAGE 1

REVISION 0

DATE SeP 1, 1978

I. SCOPE

A. This standard outlines requirements for welding, including preheat and postweld heat treatment of vessels, heat exchangers, piping, piping components, heater tubing and other equipment. Requirements for weld overlay cladding, fabrication of integral clad plate and tube to tubesheet welding are also included.

B. Except as supplemented in this standard, welding shall conform to the requirements of the latest revision and addenda of the following codes:

1. ANSI B31.3 - Chemical Plant and Petroleum Refinery Piping Code

2. ANSI B31.1 - Power Piping Code

3. ASME Boiler and Pressure Vessel code, Sections I, VIII and IX

4. State and local codes

C. In no case is this standard to be used to supercede, delete and/or lower applicable code requirements.

D. Any conflict between this standard and other Foster wheeler drawings, specifications, standards, codes, etc. shall be brought to the attention of Foster Wheeler in writing, for clarification prior to any action by the vendor. The more stringent requirements shall govern until written resolution is provided by Foster wheeler.

\section{WELDING - REQUIREMENTS AND RESTRICTIONS}

\section{A. General}

1. Acceptable welding processes are given below. Requests to use any other welding processes shall be submitted to Foster wheeler for review.
a. SMAW - Shiolded Metal Are Welding
b. GTAW - Gas Tungsten Arc Welding
c. GMAW - Gas Metal Arc Welding
d. FCAW - Flux-Cored Arc Welding
e. SAW - Submerged Arc Welding
f. FGW - Fuel Gas Welding
g. PAW - Plasma Arc Welding
h. ESW - Electroslag Welding

2. The strength of deposited weld metal shall be at least equal to the specified minimum tensile strengths of the material being welded. 


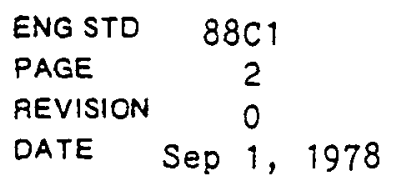

\author{
WELDING REQUIREMENTS \\ FOR EQUIPMENT AND PIPING
}

FOSTER

PROCESS PLANTS DIVISIOA

3. Where hardness limits are prescribed in the job specirication for welded equipment, weld metal and heat affectec zone hardnesses shall not exceed those values. Hardness limits for piping shall not exceed the following values:

$\begin{array}{cc} & \text { MAXIMUM } \\ \text { BASE METAL } & \text { HARDNESS } \\ \text { P - NUMBER } & \text { BRINELL } \\ 1 & 200 \\ 3 & 225^{*} \\ 4 & 225^{*} \\ 5 & 241^{*} \\ 6 & 241^{*}\end{array}$

Required by ANSI B31.3

When welding dissimilar metals, the maximum hardness allowed shall be the hardness prescribed for the higher alloy.

4. Unless otherwise approved in writing by Foster wheeler only low hydrogen electrodes shall be used for shielded metal arc welding all carbon and low alloy steels, except for root pass welding of single welded foints (See Paragraph 5 below).

5. Where access preciudes the use of couble welded butt joints, single welded joinis shall be wade using a root pass deposited by the GTAW (TIG) or GMAW (short arc) processes, except that for carbon steel piping, the use of $E 6010$ electrodes for root pass welding by SMAH is also acceptable. The use of consumable insert rings for gas tungston are welding is an exception.

6. Unless specifically approved in writing by by Foster wheeler, nonremovable backing rings or strips shall not be used for butt joints.

7. All full-penetration butt joints which are accessible from both sides shall be back gouged or ground to sound metal after welding the first side and then back welded on the reverse side, unless the welding procedure otherwise assures that full penetration will be achieved.

8. All welds of nozzles and manways to equipment shelis and heads shall be full penetration welds.

9. Internal purging with inert gas is required for gas tungsten arc welding of single-welded butt joints in non-ferrous metals, and ferrous metals with over $3 \%$ total alloy content. When consumable inserts are used, internal purging is required for all materials. 
10. Self-shielded flux-cored arc welding, without external shielding gas, of carbon or low alloy steels is not acceptable for pressure joints or for welds subject to vibration.

11. The use of neutral flux (non-voltage sensitive) is required for submerged arc welding of all materials other than carbon steels, and carbon steels over one inch thick.

12. For submerged arc welding, the use of alloy wire and neutral flux, rather than alloying through the flux, is required where an alloy weld deposit is desired.

13. For submerged arc welding, the flux and wire combination actually used shall be the same as used in the procedure qualification.

14. Use of manual submerged arc welding is not permitted for pressure joints.

15. Submerged arc flux shall be specified by manufacturer.

16. For gas metal arc welding, the $\mathrm{CO}_{2}$ spray transfer technique shall not be used for the root pass of welds which are not back gouged.

17. The oxy-fuel gas process is restricted to butt or socket welding of heat exchanger carbon steel tubing not over two inches nominal diameter.

18. Welding of proprietory items such as alonized pipe, etc. is not permitted without prior Foster wheeler approval.

B. Short Arc Welding Restrictions

1. Pressure Vessels

Manual short-arc or pulsed are welding is:

a. Allowed for root pass welding of butt joints in any material regardless of thickness.

b. Allowed for full thickness butt welds and fillet welds in pressure parts, structural supports, and equipment internals if the thickness of either material at the joint does not exceed $3 / 8 "$ ".

c. Not allowed where large material mass heat sinks can affect the integrity of welds, such as nozzle welds, reinforcing pads, and flange welds where the thickness of either material at the joint exceeds $3 / 8 "$ ". 
ENG STD $88 \mathrm{C} 1$

PAGE 4

REVISION. 0

DATE Sep 1, 1978
WELDING REQUIREMENTS

FOR EQUIPMENT AND PIPING
FOSTER

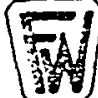

MMEEIER

PROCESS PLANTS OIYISION

2. Piping

a. Manual short arc or pulsed are welding is allowed for full thickness butt welds in piping, with the following limitations:

(1) It way be used for root pass welding of butt joints in any material regardless of thickness.

(2) It may be used provided the wall thickness does not exceed $3 / 8$ " nominal.

(3) It cannot be used for pipe with diameters less than $3^{n}$.

(4) It may be used provided the direction of travel is indicated in the procedure.

(5) 5\% of welds performed shall be radicgraphed in addition to any applicable code requirements. Inspection shall be performed as stated in Section $V$ of this standard.

b. Automatic short arc or pulsed arc welding is allowed for full thickness butt welds in piping within the following limitations:

(1) No limit on thickness.

(2) No restriction on diameter.

(3) 1G (Rolled) position only.

(4) For thicknesses over 3/8", a minimum current of 170 amperes is required for all passes arter the root pass.

(5) Use of an automatic arc oscillator is recommended for jolnt thicknesses over $3 / 8^{n}$.

(6) $5 \%$ of weids in thicknesses up to $3 / 8^{n}$ and $10 \%$ of welds in thicknesses over $3 / 8$ " must be radiographed in addition to any applicable code requirements. Technique and acceptance standards shall be as stated in Section $V$ of this standard.

(7) Not allowed where large material mass heat sinks can affect the integrity of welds, such as couplings, weldoletts, branch welds, flllet welds on slip-on flanges, socket-welded flanges and fittings, etc. where the thickness of either material at the joint exceeds $3 / 8^{\prime \prime}$. 
ENG STD $88 \mathrm{C}$

PAGE

\section{Base Metal Preparation}

1. Joint preparations for welding may be performed by machining, grinding, thermal cutting or combinations thereof. Excessively deep or sharp irregularities in joint edges shall be removed by machining or by grinding. joint edges shall be crack and lamination free prior to welding.

2. Prior to welding, all oil, grease, dirt, rust or loose scale shall be removed from the surfaces of the joint and the adjacent base metal within one inch from the edge of the joint.

D. Welding Clad \& Overlay Materials

1. Weld overlay procedures shall be qualified in accordance with the requirements of ASME Code, Section IX, Paragraph QW-214 and QW-381. Qualification weld test specimens shall be subjected to PWHT, if required, equivalent to that anticipated for fabrication, including aggregate time at temperature, with appropriate allowance for repair cycles.

2. The minimum clad or overlay thickness shall be as specified on drawings and requisitions.

3. Weld overlays shall meet the chemical requirements for the specified type or grade.

4. Where specifications require chemical analysis of stainless steel overlays in production, and where such overlays will experience post weld heat treatment in the temperature range from $1200 F$ to $1350 \mathrm{~F}$, the ferrite number for Type 309L/308L, and the ferrite number and $\mathrm{Cb} / \mathrm{C}$ ratio for Type 347 shall not exceed the following values depending upon the chromium content.

$\begin{array}{ccc}\text { CHROMIUM CONTENT } & \text { FERRITE } & \text { Cb/C } \\ \text { OF OVERLAY } & \text { NUMDER } & \\ \text { RATID }\end{array}$

5. Ferrite number may be determined by chemical analysis and reference to a DeLong or Schaeffler diagram or by measurement with calibrated magnetic instruments. 


$\begin{array}{lccc}\text { ENG STD } & 88 \mathrm{C} 1 & & \\ \text { PAGE } & 6 & \text { WELDING REQUIREMENTS } & \text { FOSTER } \\ \text { REVISION } & 0 & \text { FOR EQUIPMENT AND PIPING } & \\ \text { DATE } & \text { SEP } & 1,1978 & \text { MROEESS PLANTS DIYISION }\end{array}$

E. Heat Exchanger Tube to Tubesheet Helds

1. Tube to tubesheet seal welds are required for any of the following conditions:

a. When specified in the job specification.

b. When design pressure is 1500 psiz and greater but differential oressure is less than 1000 psig.

2. Tube to tubesheet strength welds are required for any of the following conditions:

a. When specified in the job specification.

b. For waste heat boilers.

c. When design pressure is 1500 psig and greater with differential pressure of 1000 psig and greater.

d. When design temperatures are greater than $750 \mathrm{~F}$.

3. When tube to tubesheet seal welds are specified in the jot specification, they shall be in accordance with Figure PFT-12.1 (e), Section I of the ASME Boiler and Pressure Vessel Code. When strength welds are specified they shall be in accordance with Figure PFT-12.1 $(\mathrm{g})$. For exchanger designs where the tubes are considered as stays, only strength (not seal) welds shall be used.

4. For exchangers in aqueous hydrogen sulfide service, carbon steel tubesheets shall have $0.21 \% \mathrm{C}$ maximum (SA-516 Gr 55 or 60) and carbon steel tubes $0.18 \% \mathrm{C}$ máximum. Hardness of welds and heat affected zone (HAZ) shall not exceed 225 HS.

5. Tube to tubesheet mock-up samples shall be submitted to Foster Wheeler for any of the following conditions:

a. When specified on the Material Requisition.

b. Ay material combination involving $P$-numbers of 21 or greater. (P number from ASME code, Section IX, Table QW-422).

c. When strength welds are specified.

6. Tube to tubesheet mock-up samples shall be constructed using actual production welders, materials and procedures for the piece of equipment involved.

7. Tube to tubesheet mock-up samples shall have a minimum of 6 tubes 3 inches in length from the backside of the tubesheet, using the same pitch arrangement as the piece of equipment involved. 
FOSTER WHEELER

PROCESS PIANTS DIVISION
WELDING REQUIREMENTS

FOR EQUIPMENT AND PIPING
ENG STD $88 \mathrm{C} 1$

PAGE 7

REVISION 0

DATE Sep 1, 1978

F. Selection of Welding Filler Metals

1. Ferritic Steels

Recommended filler metals for similar and dissimilar welds in ferritic steels are given in Table 2 and Table 3.

2. Austenitic Stainless Steels and High Nickel Alloys

Recommended filler metals for joining similar and dissimilar stainless steels and high nickel alloys are given in Table 4.

3. Aluminum and Aluminum Alloys

Recomended filler metals for joining similar and dissimilar aluminum and aluminum alloys are given in Table 5 .

4. Integral Clad materials

Recommended filler metals for welding integrally clad materials are given in Table 6 .

5. Ferritic Steels to Austenitic Stainless Steels and to High-Nickel Alloys

a. For carbon and low allow steels welded to 300 series austenitic stainless steels use Type 309 or $309 \mathrm{~L}$ stainless steels, or nickel-chromium-iron alloy filler metals such as ENiCr Fe-3 (Inconel 182), ENiCrFe-2 (Inco-Weld A), or ERNiCr-3 (Inconel 82).

Where thermal cycling conditions and operating temperatures over $800 \mathrm{~F}$ exist, the Inconel filler metals are preferred, except where the environment contains sulfur.

b. For carbon and low alloy steels welded to Inconel or Incoloy alloys, use Inconel welding filler metals ENiCrFe-3 (Inconel

- 182), ENiCrFe-2 (Inco-Weld A), or ERNiCr-3 (Inconel 82).

c. For carbon and low alloy steels welded to Monel (nickel-copper alloy) use Monel filler metals ENiCu-7 (Monel 190) or ERNiCu-7 (Monel 60).

6. Deviation from the listed tables shall be indicated in the welding procedures. 
ENG STD $88 \mathrm{C} 1$

PAGE 8

AEVISION 0

DATE SED 1. 1978

WELDING REQUIREMENTS

FOR EOUIPMENT AND PIPING
FOSTER

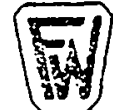

WHEELER

PROCESS PLANTS DIVISION

III. PREHEAT

A. Ferritic Steels

1. Vessels and Exchangers: Preheat shall be in accordance with ASME Boiler and Pressure Vessel Code, Section VIII: Apdendix $?$ recommendations as a minimum, or the applicable requirements of the Code.

2. Piping: Preheat shall be in accordance with the requirements or recommendations, as aDdicable, of ANSI B31.3. Chemical Plant and Petroleum Refinery Piding Code. or ANSI B 1.1 Power Piding Code.

B. Austenitic Stainless Steels and High Nickel. Alloys

For all thicknesses of austenitic stainless steels, HK, HT, Incoloy and high nickel alloys preheat shall be $50 \mathrm{~F}$ minimum. The maximum interpass temperature shall be $350 \mathrm{~F}$.

IV. POSTWELD HEAT TREATMENT

A. For all equidment and Dioing. Dostweld heat treatment shall be in accordance with the aoorodriate ASME code and Foster wheeler Heat Treatment Engineering Standards.

B. Vessels: Postweld heat treatment shall be in accordance with the reouirements of ASME Boiler and Pressure Vessel Code. Section VIII. or Section I as apolicable.

C. Exchangers: Postweld heat treatment shall be in accordance with the requirements of ASME Boiler and Pressure Vessel Code. Section VIII. and the TEMA Class specified on the Material Requisition.

D. Piping: Postweld heat treatment shall be in accordance with the requirements of ANSI B31.3. Or ANSI B31.1 as aDolicable.

E. When Dostweld heat treatment is soecified for chemical or refinerv orocess reasons no welding nor arc strikes are Dermitted after final Dostweld heat treatment. regardiess of Code orovisions to the contrary.

V. QUALITY CONTROL REQUIREMENTS

A. All welds shall have a workmanlike finish to satisfy the requirements of the avolicable Code and/or the intended apolication.

B. Relnforcement of butt welds shall be in accordance with the requirements of the adolicable Code. 
WELDING REQUIREMENTS

FOR EQUIPMENT AND PIPING
ENG STD $88 \mathrm{C} 1$

PAGE 9

REVISION 0

DATE Sep 1, 1978

C. Weld repairs shall comply with the requirements of the applicable code, including preheat requirements or recommendations, postweld heat treatment requirements, and nondestructive examination.

D. For pressure containing items, all required repairs of base metal shall be reported to Foster Wheeler for review and approval, prior to making the repair.

E. Inspection shall be performed on all full thickness butt welds as stated below:

1. Piplng

a. Radiographic technique and acceptance standards shall conform to ANSI B31.3, or ANSI B31.1 as applicable.

b. Three-fifths of the welds examined shall consist of welds joining a welding neck flange to another component if the fabrication involves such joints.

c. The work of all welers and welding operators for each P-number shall be included in radiography.

2. Vessels and Exchangers

a. Radiographic technique and acceptance standards shall conform to ASME Boiler and Pressure Vessel Code, Section VIII, Paragraph UW-51 or UW-52 as applicable; or ASME Boiler and Pressure Vessel Code, Section I, Paragraph PW-11, Pi-41, and PW-51.

b. The work of all welders employed on the job shall be included in this radiography.

c. When submerged arc welding has been used for main seams, all intersections of seams, and all stopping and starting points of weld beads shall be radiographed. 


$\begin{array}{lcc}\text { ENG STD } & 88 \mathrm{Cl} \\ \text { PAGE } & 10 \\ \text { REVISION } & 0 \\ \text { DATE } & \text { SeP } & 1,1978\end{array}$

WELDING REQUIREMENTS

FOR EQUIPMENT AND PIPING
FOSTER

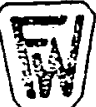

WHEESER

PROCESS PLANTS DIYISION

\section{F. Right of Access}

Representatives of Foster Wheeler, the Authorized Inspection Agency, and the client or his agent, shall have access to the vencor's facilities and equipment for the purpose of inspection and alidit of work and waterials. The Eoster wheeler representative shall have free entry, at all times while work on this Contract is being performed, to all parts of the vendor's works that concern the fabrication, assembly and/or installaion. The vendor shall afford the inspector 311 reasonable facilities to satisfy him that the work is being furnished in accordance with the Contract. All inspection shall be conducted so as not to interfere unnecessarily. With the operation of the works.

\section{PROCEDURE SUBMITTAL REQUIREMENTS}

A. Welding procedures shall be submitted to Foster wheeler for approval for any one of the following conditions:

1. Any items which receive postweld heat treatment for either process reasons or per the ASME Boiler and Pressure Vessel Code.

2. All materials or material combinations with $p$ Numbers of 3 or greater. ( $\mathrm{P}$-number from ASME Boiler and Pressure Vessel Code, Section IX, Table QW-422).

3. Any item containing pressure greater than 1000 psig, and temperatures which are greater than $800 \bar{F}$, or less than $-20 . \bar{F}$.

B. Vendor shall prepare and qualify welding procedures in accordance witn the requirements of Section IX of the ASME Soiler and Pressure Vessel Code. The vendor shall submit an index of all weld prociedures required for the job accompanied by four copies of each procedure (including the Procedure Qualification Record). In addition, weld maps shall be submitted for vessels and exchangers.

C. AIl procedures shall be in accordance with the edition of Section IX of the Boiler and Pressure Vessel Code in effect on the date the Foster Wheeler Purchase Order is placed.

D. Postweld heat treatment procedures for field PWHT and/or local PHFT for lined, clad or weld overlayed equipment shall be submitted to Foster wheeler for review and approval.

E. All procedures shall be submitted at least one month prior to required fabrication date. Submittals shall be made in accordance with the job General Notes Requisition.

F. All procedures shall contain the speciflc information required in Table 1 . 


\section{FOSTER WHEELER}

PROCESS PLANTS DIVISION
WELDING REQUIREMENTS

FOR EQUIPMENT AND PIPING
ENG STD $88 \mathrm{C} 1$

PAGE

REVISION 0

DATE SeP 1, 1978

TABLE 1 - SPECIFIC ITEMS TO BE INCLUDED IN WELDING PROCEDURES

DESCRIPTION

a Welding current type, polarity, amperages and voltages including appropriate ranges

b Filler metal size, type, classification, A-number and $F$-number where classified. If no classification is available, give manufacturer's designation

c Nonconsumable electrode type

d Arc starting aids or devices

e Shielding gas composition and flow rate (as applicable)

$f$ Composition and flow rate of internal gas purging (as applicable)

8 AWS classification, if any, and manufacturer's trade name of designation for welding flux

h Travel speed for mechanized welding

1 Special requirements such as constant potential power sources, pulse setting, wire feed or oscillation rates, electrode stick-out, etc. (as applicable)

f Single or multiple arcs

$k$ Specific precautions that will be taken for fleld welding, if applicable, to prevent wind or drafts from interfering with the shielding gas protection 


$\begin{array}{lc}\text { ENG STD } & 88 \mathrm{C} 1 \\ \text { PAGE } & 12 \\ \text { REVISION } & 0 \\ \text { DATE SEP } & 1, \quad 1978\end{array}$

WELDING REQUIREMENTS FOR EQUIPMENT AND PIPING
FOSTER WHEFLR

PROCESS PLANTS DIVISIOA

TABLE 2

RECOMMENDED FILLER METALS EOR WELDING

FERRITIC STEELS

(Code Letter Definitions are given in Table 3)

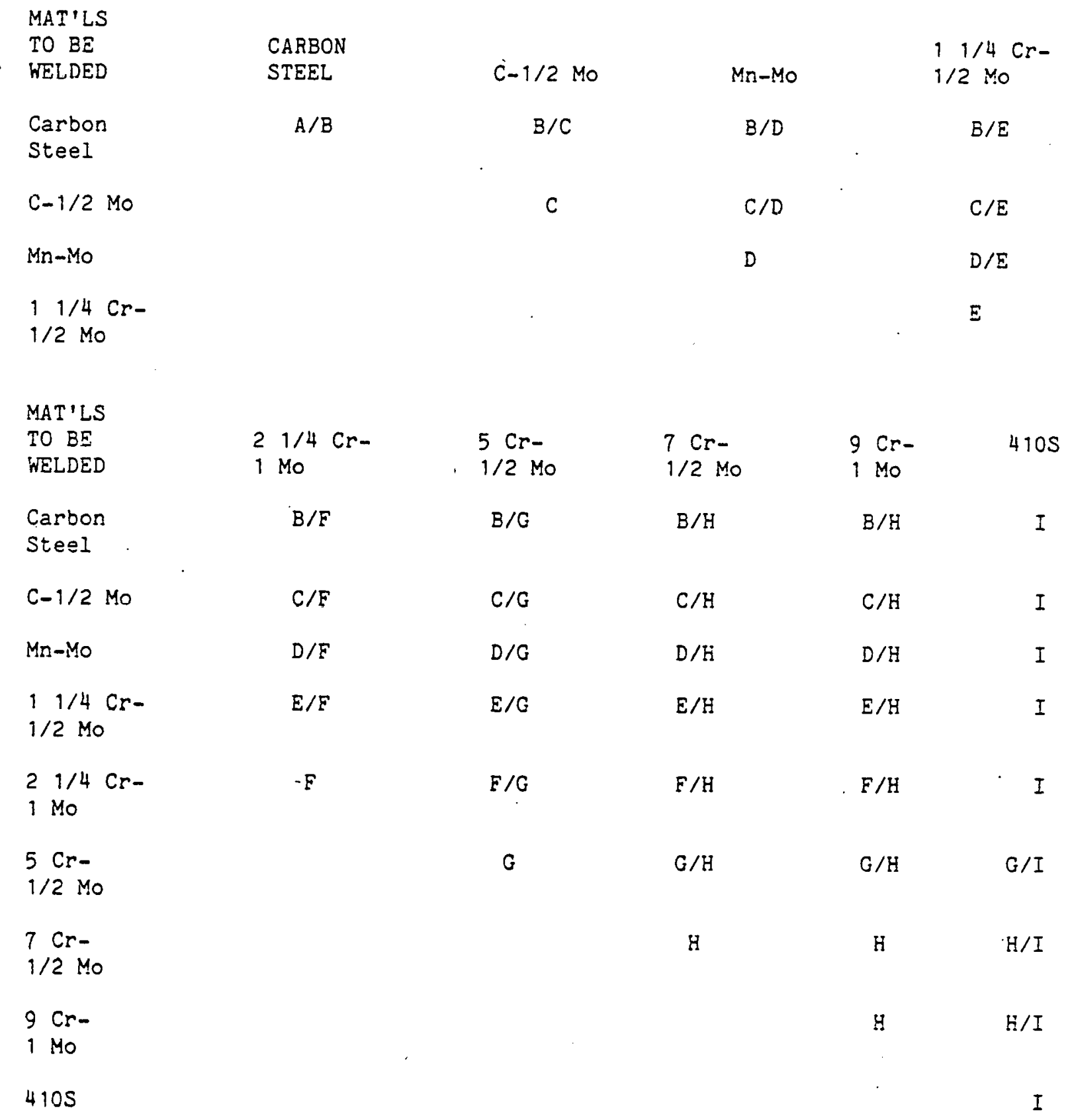




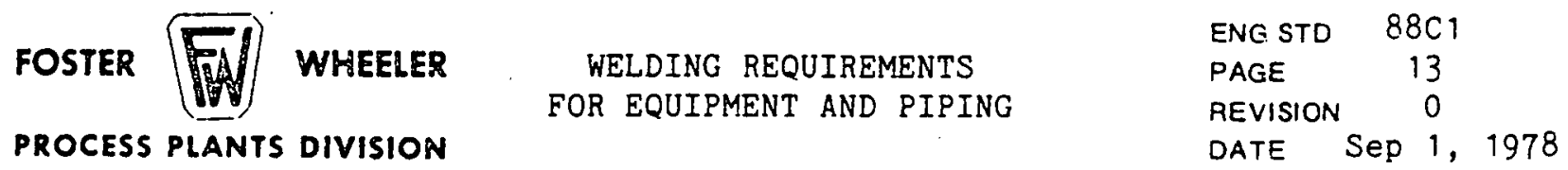

TABLE 3 - RECOMMENDED FILLER METALS FOR JOINING FERRITIC STEELS

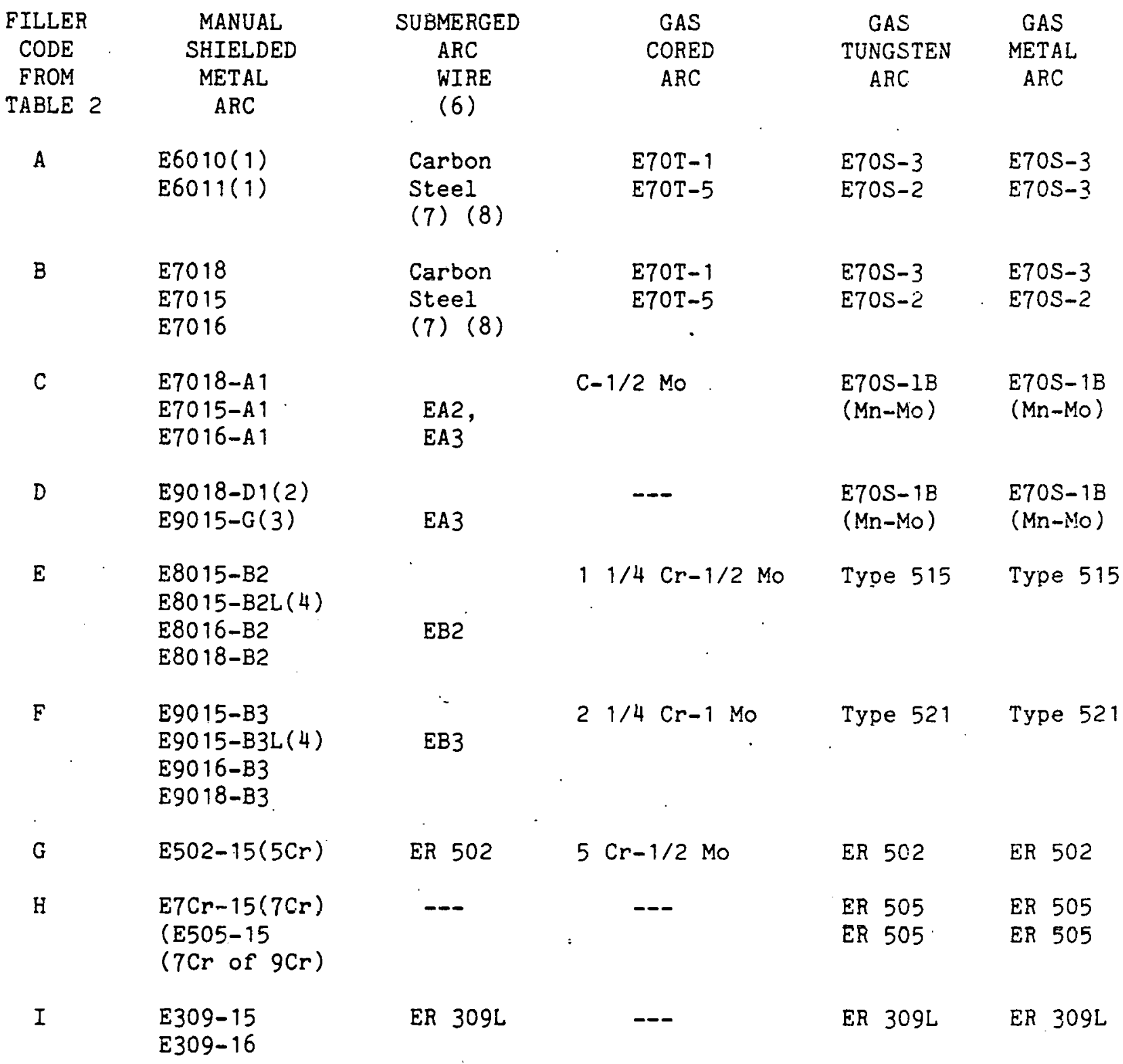

NOTES FOR TABLE 3 :

1. Use only as ront pass.

2. For hydrogen service, special order resulting in welds with 0.40 to $0.60^{\circ}$ Mo content must be used. 


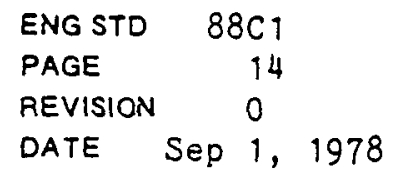

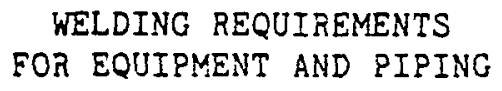

\section{FOSTER WHEELER \\ PROCESS PLANTS DIYISIOA}

3. This refers to special E9015-G electrode developed by Champion to weld Mn-Mo steel.

4. For equipment operating in creep range do not use low carbon grade of filler metal.

5. Where austenitic stainless steel filler metal is used for dissimilar metal joints, thermal stresses resulting from difference in coefficients of thermal expansion shall be considered.

6. Alloy welding electrodes shall have the alloying agents in the wire and not in the flux.

7. Manganese - Molybdenum steel electrode wires may be used provided the weld metal hardness does not exceed a hardness of 200 BHN.

8. Electrodes specified in ASME SA5.7, and electrode classifications EL 12 or EM12K, speclfled in ASME SFA5.23, shall not be used for submerged arc welding carbon steels having a minimum specified tensile strength of 70,000 osi or higher, where postweld heat treatment is specified.

TABLE 4 - RECOMENDED FILLER METALS FOR JOINING HIGH-NICKEL ALLOYS (1), (2), (3), (4)

AUSTENITIC STAINLESS STEELS AND 301

MAT'LS

TO BE

WELDED

$304 \mathrm{~L}$

309

3095

310

316

$316 \mathrm{~L}$

301

304

302

308

308

308

308

308

308

304

$304 \mathrm{~L}$

$308 \mathrm{~L}$

308

308

309

309

309

309

308

$308 \mathrm{~L}$

$309 \mathrm{~s}$

310

309
316

316

309

310

$310 \mathrm{~S}$

309

309

316

316

390

316

316

$316 \mathrm{~L}$

$310 \mathrm{~L}$ 


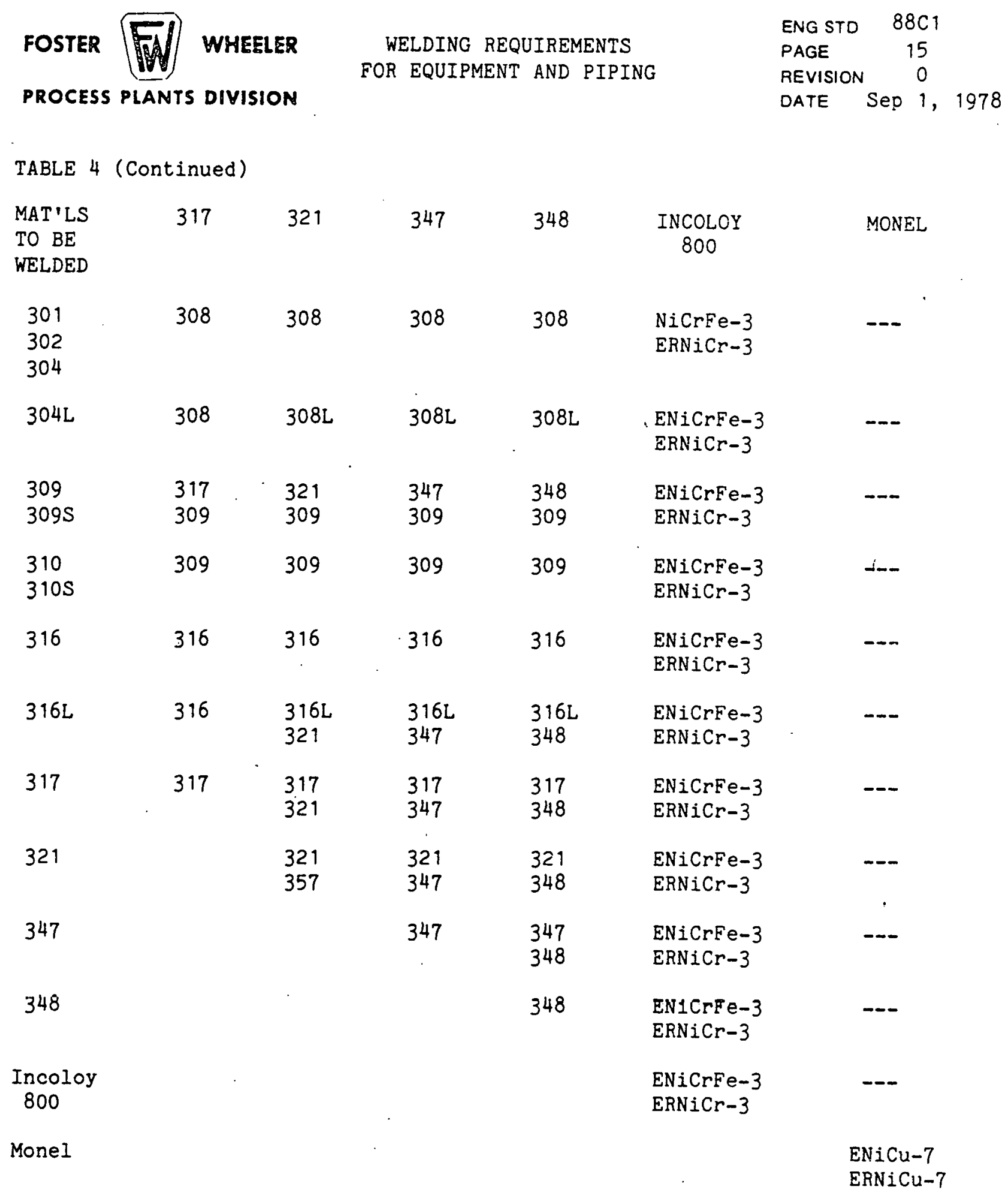




\begin{tabular}{|c|c|c|}
\hline ENG STD & $8 \varepsilon$ & $8 \mathrm{Cl}$ \\
\hline PAGE & & 16 \\
\hline REVISION & & 0 \\
\hline DATE & Sep & , \\
\hline
\end{tabular}

\section{WELDING REQUIREMENTS}

FOR EQUIPMENT AND PIPING
FOSTER

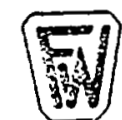

WHEELER

NOTES FOR TABLE 4:

1. Deposited Type 300 stainless steel weld metal shall have a delta ferrite number as indicated in Paragraph II.D.4.

2. Filler metals used in welding $316,316 \mathrm{~L}$ or 317 parts in fatty acid service shall contain a minimum Mo content of $2.5 \%$ and $\equiv$ maximum carbon content of $0.03 \%$.

3. Where Type 321 filler metal is specified, this applies to barewelding filler metal. For coated electrodes, use Type 347 .

4. Filler metals used in welding Monel parts in hydrofluoric acid service shail contain no columbium.

TARLE 5 - RECOMMENDED FILLER METALS FOR JOINING ALUMINUM AND ALUMINUM ALLOYS ( 1 )

\begin{tabular}{|c|c|c|c|c|c|c|}
\hline $\begin{array}{l}\text { MAT'LS } \\
\text { TO BE } \\
\text { WELDED }\end{array}$ & 1060 & 1100 & 3003 & 3004 & 5050 & $\begin{array}{l}5052 \\
5652\end{array}$ \\
\hline 1060 & $\begin{array}{l}\text { ER } 1260 \\
\text { ER } 4043\end{array}$ & $\begin{array}{l}\text { ER } 1100 \\
\text { ER } 4043\end{array}$ & $\begin{array}{l}\text { ER } 1100 \\
\text { ER } 4043\end{array}$ & ER 4043 & $\begin{array}{l}\text { ER } 1100 \\
\text { ER } 4043\end{array}$ & ER4043 \\
\hline 1100 & & $\begin{array}{l}\text { ER } 1100 \\
E R 4043\end{array}$ & $\begin{array}{l}\text { ER } 1100 \\
\text { ER4043 }\end{array}$ & $\begin{array}{l}\text { ER } 4043 \\
\text { ER5356 }\end{array}$ & $\begin{array}{l}E R 4043 \\
\text { ER5356 }\end{array}$ & $\begin{array}{l}\text { ER4043 } \\
\text { ER5356 }\end{array}$ \\
\hline 3003 & & & $\begin{array}{l}\text { ER } 1100 \\
\text { ER } 4043\end{array}$ & $\begin{array}{l}\text { ER4043 } \\
\text { ER5356 }\end{array}$ & $\begin{array}{l}\text { ER4043 } \\
\text { ER5356 }\end{array}$ & $\begin{array}{l}\text { ER4043 } \\
\text { ER5356 }\end{array}$ \\
\hline 3004 & & & & $\begin{array}{l}\text { ER } 4043 \\
\text { ER5356 }\end{array}$ & $\begin{array}{l}\text { ER4043 } \\
\text { ER5356 }\end{array}$ & $\begin{array}{l}\text { ER } 4043 \\
\text { ER5356 }\end{array}$ \\
\hline 5050 & : & & & & $\begin{array}{l}\text { ER4043 } \\
\text { ER5356 }\end{array}$ & $\begin{array}{l}\text { ER4043 } \\
\text { ER5356 }\end{array}$ \\
\hline $\begin{array}{l}5052 \\
5652\end{array}$ & & & & & & $\begin{array}{l}\text { ER5654 } \\
\text { ER5356 }\end{array}$ \\
\hline
\end{tabular}




$\begin{array}{llll}\text { FOSTER WHEELER } & \text { WELDING REQUIREMENTS } & \text { ENG STD } & 88 \mathrm{C} 1 \\ \text { PROCESS PLANTS DIVISION } & \text { FOR EQUIPMENT AND PIPING } & \text { PAGE } & 17 \\ \text { REVISION } & 0\end{array}$

TABLE 5 (Continued)

MAT'LS

TO BE

WELDED

5083

5086

5154

5254

5456

6061

6063

1060

ER5356

ER5356

ER4043

ER5183

ER5356

ER4043

ER4043

1100

ER5356

ER4043

ER4043

ER5 183

ER5356

ER4043

ER4043

ER4043

ER4043

ER5356

ER4043

ER4043

ER4043

ER4043

ER5183

ER5356

ER5556

ER4043

ER5556

ER5356

ER5654

ER5356

ER5356

5050

ER5356

ER5356

ER5654

ER5356

ER4043

ER5556

ER5556

ER5356 *

ER5556

ER5356

5052

ER5356

ER5356

ER56\%,4

ER5356 *

ER5356

ER5356

5652

ER5556

ER5556

ER5556

ER5556 *

5083

ER5 183

ER5356

ER5356

ER5183

ER5356

ER5356

ER5556

ER5556

ER5556

ER5556

5086

ER5356

ER5356

ER5556 *

ER5356

ER5356

ER5556

ER5654

ER5356 *

ER5556

ER5556

5154

5254

5456

ER5356

ER5556 *

ER5356

ER5556

ER5556

ER5356

ER5356

ER5556

6061

6063

ER4043

ER5356

NOTES FOR TABLE 5:

1. The filler metal listed on the top line of each combination is the preferred wire. The filler metal listed on the bot.tom line of each combination is an acceptable alternate. 
* The choice of filler metal may be limited by service conditions such as immersion in fresh or salt water. exposure to scecific chemicals. or to a sustained temoerature between $150 \mathrm{~F}$ and $450 \mathrm{~F}$. Contact Foster wheeler Technical Services and Quality Control Department if such conditions exist for soecific recommendations.

TAELE 6 - RECOMENDED FILLER METALS FOR NELDING INTEGRALLY CLAD MATERIALS

CLADDING
MATERIAL

$70 \mathrm{Ni}-30 \mathrm{Cu}$

(Annealed Monel).

$12 \mathrm{Cr}$

\section{SPECIFIC \\ REOUIREMENTS}

\author{
Troe 410 \\ Troe $410 \mathrm{~S}$
}

\section{FILLER METALS FOR \\ OVERLAYING WELDED JOINT (4)}

ASME SFA-5.11

Class ENiCu-7 (1)

Do Not Overlav

ASME SFA-5.11

Class ENiCrFe-3 (2)

ASME SFA -5.4

Class E309L (3)

\section{FIRST PASS}

SUBSEQUENT PASSES

Austenitic
Stainless
Steel

Troe 304
Troe $304 \mathrm{~L}$
Troe 316
Troe $316 \mathrm{~L}$
Troe 321
or

$309 \mathrm{~L}$

$309 \mathrm{~L}$

$309 \mathrm{~L}$

$309 \mathrm{~L}$

309L
$308 \mathrm{~L}$

$308 \mathrm{~L}$

316

$316 \mathrm{~L}$

347

Troe 347

NOTES FOR TABLE 6:

1. ENiCu-7 (Monel welding electrode 190. or equal)

2. ENiCrFe-3 (Inconel welding electrode 182. or eoual) oreferred for temoeratures above $800 \mathrm{~F}$ or where thermal cycling conditions are anticioated. Consult Foster Wheeler Technical Services and Cualitv Control Dedartment if environment contains sulfur above $800 \mathrm{~F}$.

3. For oderating temperatures below aooroximately $800 \mathrm{~F}$ and/or where thermal creling conditions are not severe.

4. Overlays usually reouire a minimum of two layers: however single-laver overlays are accedtable provided dimensional reouirements are met and chemical comoosition and soundness are satisfactorv. The number of lavers in oroduction shall not be less than the number of lavers in the orocedure oualification test. 
U.S. Department of Energy

Solar Steam Generation
FOSTER WHEELER ENERGY CORP. FWEC Contract 11-60863

JOB SPECIFICATION NO. 60863-89A1

\section{PRESSURE TESTING}

The subject specification is issued herewith per index of pages noted below. If this is a later revision than now in your possession, please destroy superseded pages and insert the revised pages.

Initial issue $X$

Entire specification reissued Revised pages only attached

\section{REVISION INDEX}

\begin{tabular}{lll} 
Page & Rev. \\
\hline 1 & 0 & Date. \\
2 & 0 \\
3 & 0 \\
4 & 0 \\
5 & 0 \\
6 & 0 \\
7 & 0 \\
8 & 0 \\
9 & 0
\end{tabular}

* Pages revised for this issue are noted by asterisk.

Issue No. 1 Date 4 425/79

Basis: Dow Chemical Co. Specification 


\section{PIPING TESTING PROCETURE}

\section{Scope}

1.1 To provide definite requirements for testing piping systems to be installed for or by The Dor Chomical Comoany. Various clesses of testing are included in order to ootain a stringent test of important lines, or a less rigorous test of secondary lines, as required by the service.

1.2 The term "piping system" as used herein is intended to include pipe, valves, and fittings. Vessels, instruments, and reliel devices are not, included.

1.3 The acceptance of piping systens under this specification includes approvel for pressure tightness only.

1.4 Vessels and flanged iters not included in the tests shall be isolated by Iine blinds. Line blinds shall be instelled between existing piping and new piping under test to prevent application of pressure to existing lines. The Dow representative shall be notified in advance by the contractor of test schedules and test conditions.

\section{Materials and Services}

2.1 Dow will furnish water for test purposes at existing pressures within the block or plant limits when eveileble. Don will furnish all required Freon R-12.: If a recording instruraent is required for the test, Dor will furnish the instrument and the contractor shall install and remove same. The contractor shall furmish all miscellaneous pipe, gauges, fittings, test pump, or compressors, line biinds, valves, etc., necessary to provide the proper testing equipment. AII such raterials shall be removed upon completion of testing unless shom on the drarings as part of the Iinished work. The contractor shall furnisi ell piping or hose from the source of water to the point of test connection and shall be responsible, when bidding, for determining the nearest source of water and what equipment will be needed. Alr compressurs shall be. equipped with discherge filters for removal of water, oil, and foreign matter. Maximum discharge temperature of oil lubriceted air compressors shell be $300^{\circ} \mathrm{F}$.

2.2 The contractor shall furnish experienced test crews of adequate size, equipped with sufficient and proper hand tools, to handle properly the testing operations. The Dor representative shall determine the adeciacy of all equipment used by the test crews.

2.3 The contrector shall be responsible for the removal of water used in testinis from all piping systems. Where ditches or temporary lines to ditches are necessary, the contractor shall provide them; after their use, such ditches or lines shall be removed leaving the area in its original, or equal, condition. 
2.4 If special drying or speclal cleaning is required after testing is corpleted, it will be done by Dow unless otherrise specified in the job specifications.

2.5 Blowdown of all steam lines preparatory to test or putting into service shall be done by the Dod Power Department outside block limits or by the Dow plant superintendent inside block limits. All valves connecting to existing water rains, process lines, etc., shall be opened only by Dow's proper representative.

2.6 Where large vayor or gas lines are to be hydrostatically tested, the contractor shall not start the test until he has assurance from the Dow representative that the line will support the weight of the test Iiquid.

3. Specification of Class Required

Classes of test will be specified as follows:

3.1 The line schedule issued giving general specifications for each line. such as material, size, insulation, etc., will also contain a designation of the class of test required and the test pressure.

3.2 In the absence of a line schedule, the class of test and pressure required may be covered in the job specification, construction order, or for maintenance jobs by an AVO.

4. Details of Test

\section{I General}

4.1.1 Air and instrument air supply piping shall not be cleaned or tested with water. Before the final connection is made to instrument, accessory or equipment, the lines shall be blorm free of all dirt, scale, filings, or other extraneous matter. Instrument air supply piping is defined as piping that connects instruments to the air supply system (Note: This does not include instrument pneumatic transmission tubing or pipe, which is to be cleaned and tested per 61-110 and 61-150):

All other piping shall be thoroughly cleaned and flushed with water before testing. This shall include instrument process piping, which is defined as piping that connects instruments to process lines or vessels and is to contain process fluids. Instrument process piping shall not be connected to the instrument or accessory during cleaning. After washing and prior to connection to instruments, etc., the instrument process piping sha.l be blown free of all vater and. extraneous matter. 
4.I.2 Control valves, sareity valves, rupture discs, reducing valves, level controllers, level sivitches, orifice plates, and other instruments or fittings designated by the Dor representative shall be ramoved from the lines before cleaning and replaced before testing. All such iters, except sefety velves, at'ter removal shall be cleaned separately by the contractor. The line bore orifice specers and geskets or spare rings Iurnished with meter runs shall be installed prior to cleaning and remain in place until after testing. Safety valves.and rupture discs shall be installed for Iit-up, removec during the test and reinstalied. Mrew gaskets shall be used when reinstalling all flenged items. Where control valves are to operate normelly shut, the test cress shall not test the line until the valve has been opened by the Dow representative.

4.1.3 The contractor shall be responsible for venting piping and vessels while cleaning and testing and, after testing, while draining to insure against their collapse by racuum.

4.1.4 The contractor shell be responsible for any and ail damage resulting from test pressures more than 10\% higher than specified by Dow. A safety valve or relief valve may be used at the pressure source to protect systems under test. The test cres shall be responsible for venting all sections o $\vec{i}$ piping system and vessels not under direct test to prevent overpressuring any part of system through valve leakage or excess flows.

4.1.5 Overtightening of a valve in an effort to make it hold may be cause for rejection of the valve by the Dow representative.

4.i.6 For hydrostatic tests, every precaution shall be taker for the removal of trapped air.

4.1.7 Pressure gauges shall be of a suitable scale capacity for the pressure, havling a dial at least $4 \frac{1}{2} "$ in diameter. The maximum pressure capacity shall not exceed three times the particular test pressure. The gauges shall be checked against a standard gauge by the Dor Instrument Deperiment.

4.1.8 Variations of pressure and volume due to tergerature changes shall be taken into account by the Dom representative in determining whether pressure during test is satisfactory. Visual checks of short duration mey be rade at intertueriate pressures at. the nption of the Dor representative. 4.I.9 All hydrostatic tests are assuned to be made, using rater,
unless othervise statei. 
4.1.10 Presence of the Dor representative is not necessary while initial going-over of lines for leaks is progressing.

4.1.11 No insulation shall be allowed on systems under test except on those parts which have had a certified shop test.

4.1.12 The test fluid shall not be ellowed to freeze. When testing steel piping below $40^{\circ} \mathrm{F}$, a written Safe Vork Procedure will be required to protect against brittle fracilire hazards.

4.1.13 Pressure tests shall include as much instrument process piping as possible. Where an instrument process line contains more than one block valve, all valves should be open except that nearest the instrument.

4.1.14 All instruments and similar special equipment are to be protected against overpressure during cleaning and testing by disconnecting the piping between the closed block valves and the instruments. Direct operated or self-contained regulators are to be removed or blocked and vented. Special care is to be exercised in the protection of flat actuated devices, such that float is not subjected to collapsing pressure.

4.1.15 Expansion joints having tie-rods may be tested as part of the piping system unless otherwise specified. The tie-rods must be hand tight, with no slack under the outside nuts. Expansion joints not having tie-rods shall be removed or isolated from the test. The contractor shall check the drawings and specifications for any specific iustallation or operating instructions pertaining to the expansion joint.

4.1.16 A written Safe Work Procedure shall be subritted by the contractor for approval of the Dow representative and manufacturing representative prior to beginning of Class D Pneumatic or Class K Ultrasonic tests if the test pressure is to exceed 15 psig. The procedure shall cover a minimum of the folloring items; Pretest visual inspection, areas to be roped off, time schedule, and indoctrlnation of personnel on hazards involved.

4.1.I7 At the completion of the test, all blinds, plugs, caps, etc. used to isolate vessels, instruments, etc. shall be removed, flange faces and threads inspected for damage and piping re-connected. Gaskets removed after tests shall not be re-used. Special care is required when reconnecting these points to avoid leaks. 
5. Classes of Tests

5.1 Class B - Hydrostatic:

5.1.I Each valve shall be pressure tested to the satisfaction of the Dow representative. Velve test shall not exceed 20 ninutes. Where valves occur in headers, both sices shall be tested at the option of the Dor representative.

5.1.2 Arter all valves have been iested, the entire system shalI hold the designated pressure for a period of four hours.

\subsection{Class C - Hyarostatic:}

5.2.I Complete line or section of line containing several valves and branches may be tested at one time. The duration of test shall not exceed four hours. Generally, the Dor representative shall fix the duration of test a.s only sufficient to exanine the line. and satisfy himself that there is no leakage.

\subsection{Class D - Preumetic:}

CAUTION: Pneumatic testing should be used only as a last alternetive. Carefully planned and supervised procedures shall be used to guerd agginst the hazards of latent energy of compressed gases. ( See 4.1.16)

This class covers tests made with air, nitrogen, or other gases for piping designed in accordance with AISSI B31.3, Code for Petroleum Refinery Piping. Where applicable, the test shall meet the requirements of OSHA 1910.106, Flammeble and Combustible Liquids, and 1910.110, Storage and Handling of Liquified Petroleum Geses. Piping designed by other codes shall be tested in accordance with those codes.

\subsection{Low Pressure Test - Maximum 15 psig.}

5.3.1.I Frior to testing, a thorough visual inspection sholl be made for deiects such as improper materials, poor gasket installation, loose joints, etc. All bolts must be made up tight.

5.3.1.2 AII flanged joints shall be taped shui using a suitable adhesive coated paper tape with a small vent hole punched in the tape. The tape shall be applied very carefully to insure an airtignt seal all eround both flanges. 
5.3.1.3 Soapsuds made from mild soap or a commercial bubble test fluid shall be applied to each vent hole for flanged joints and all around each screwed or welded joint. Any leak detected shall be marked for the subsequent inspection of the Dow representative if he is not immediately present.

5.3.1.4 The first leakage check shall be made at 5 psig max. Any detectable leaks shall be eliminated before proceeding. The lealage test may be repeated at higher pressures not to exceed 15 psig or the specified test pressure, whichever is lower, as directed by the Dow representative.

5.3.2 High Pressure Test - Above 15 psig

CAUTION: Special precautions required. (See 4.i.16)

Joints are not to be taped for this test. All personnel shall be kept clear of the immediate area while the test pressure is being raised. The pressure shall be raised slowly in stepwise fashion in increments of not more than $20 \%$ of the maximum test pressure (10 psig steps are acceptable up to 50 psig test pressure).

Pause 5 minutes minimum at each step to allow for inspection and equalization of stralns. Leak detector used shall be ultrasonic type per 5.8.3. If there is evidence of leakage, the pressure will be reduced by. a mininum of $20 \%$ or as required to locate and correct any leakage detected. The testing shall continue stepwise until the final test pressure is reached and held for 10 minutes minfmum without evidence of leakage.

\subsection{Class F- Fire Mains, Sprinkler and Spray Systems}

5.4.1 Wet Pipe Sprinkler Systems. (See Eng. Spec. 47-101 and NFPA 13, 1973, Chapt. 1, Sect. 1-11)

Prior to connection to the sprinkler riser entering the building, the fire water mains shall be flushed at an approximate rate as follows, until clear:

$\begin{array}{ll}6 " & 750 \mathrm{gpm} \\ 8^{\prime \prime} & 1000 \mathrm{gpm} \\ 10^{\prime \prime} & 1500 \mathrm{gpm} \\ 12 " & 2000 \mathrm{gpm}\end{array}$

After flushing, connect the main to the riser and flush ail piping with heads in place or plugged and bulk-Dain flush connections open, using full line pressure. Where necessary, flush

(R) by sections for adequate flow through lall openings. Hydrostatically pressure test entire system for. 2 hours with heads in place at 200 psig rinimuin or 50 psig in exicess of max. static line pressure where max. Ine pressure exceeds 150 psig. 


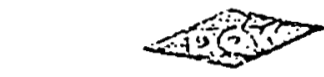

5.4.2 Water Spray Fixed Systems (deluge)

(See Eng. Spec. 47-102 and NPPA 15, 1973, Chapt. 5)

Pricr to connection to the deluge valve, the fire water mains shall be flushed at an approximate rate as follows, until clear.

$\begin{array}{ll}4^{\prime \prime} & 390 \mathrm{gpm}(10 \mathrm{ft} . / \mathrm{Sec} .) \\ 6 " & 880 \mathrm{gmp}(10 \mathrm{ft} . / \mathrm{Sec} .) \\ 8^{\prime \prime} & 1560 \mathrm{gpm}(10 \mathrm{ft} . / \text { Sect.) } \\ 10 " & 2440 \mathrm{gpm}(10 \mathrm{ft} . / \text { Sect.) } \\ 12^{\prime \prime} & 3520 \mathrm{gpm}(10 \mathrm{ft} . / \text { Sect.) }\end{array}$

After flushing, connect the main to the deluge system and flush all spray piping down stream at full line pressure with spray nozzles removed, until clear. Winere necessary, flush by sections for adequate flow through all openings.

pilot aix system piping shall be cleaned and tested as follows:

With the air filter, pressure regulator and pilot valve omitted from the test, hydrostatically pressure test the piping at $70 \mathrm{psig}$ for 1 hour with all pilot heads in place. After completion of test, drain water and blow out one branch at a time by introducing 50-75 psig air and releasing the air at the most remote pilot head opening of the branch, with all other openings closed.

A final acceptance test in operation shall be made, to be witnessed by a representative from Loss Prevention Engineering

\subsection{Class $G$ - Hyarostatic (Gravity):}

5.5.1 This test for verts, standpipes, etc., requires the filling of the - piping system with water and visual inspection for leaks. No pressure shall be applied by pump, by supply line, or other externi source. The test crew shall be responsible for filling such a system at a rate lo:* enough to prevent pressuring due to restrict.ing outflow of air. 


\subsection{Class H - Boiler Coüe:}

5.6.I Boiler piping shall be tested in accordance with the AS.E Power Boiler Code. Boiler piping includes all piping attached to the boiler, up to and including the second valve iron the boiler, for multiple-boiler installations. For single boilers, the piping may include all piping up to the first valve only.

\subsection{Class J-Halogen:}

5.7.I Halogen leak detector shall be used to detect leaks ai all welds, sears, joints, and other areas of possible leatage.

5.7.2 This test shall be made by pressuring up the piping system to be tested to $13 \mathrm{psig}$ by use of a compressed air source; then increasing the pressure to 15 psig with Freon.R-I2. The pressure shall be held at 15 psig until testing is completed.

5.7.3 All flanged joints shall be taped shut using a suitable aahesive coated paper tape with a small vent hole punched at one point, preferably on top. All bolts or studs must be made up tight. Tape shall be carefully applied to insure an airtight seal all around both flanges.

5.7.4 The Halogen testing equipment shall be General Electric Halogen Leak Detector, Type $\mathrm{H}-2$, or approved equal, and used in accordance with the manufacturer's recommendations.

\subsection{Class K - UItrasonic:}

-5.8.I Ultrasonic leak detector shall be used to detect leaks at all welds, seams, joints, and other areas of possible leakage.

5.8.2 This test shall be made by pressuring up the system to be tested to 15 psig by use of a compressed air source. The pressure shall be held at 15 psig until testing is completed. This test may be conducted at pressures above 15 psir if proper saiety procedures are observed per 4.1 .16 and 5.3.2.

5.8.3 The Ultrasonic testing equipment shall be Delcon Hodel 4918A, Euphonics Model 500, or approved equal, and used in accordance with the manuracturer's resonitendations.

\subsection{Cless L-Operatinis Pressurc:}

5.9.1 CAUTION: Tilis test, in general, is initied to sea water, river vater, and potable water systcms $:$ i.

5.9.2 Complete lines, section of lines, or complete systens may be tested at one time. 
5.9.3 This test shall be made by putting the lines to be tested into operation.

5.9.4 I istrument pneumatic transmission tubing or pipe shall be tested er Ingr. Spec. 61-110 and 61-150.

6. Retests

6.I In the event that a piping system or any part fails to pass the test prescriobd, a new test shall be applied aiter repairs and corrections have been made. This retest shall include all parts of a connected systen which may have passed a test previously, but which in the opinion of the Dow representative have been affected by the corrections made or by a delay attending to the corrections.

7. Acceptance

7.1 The Dow representative shall signify his acceptance by initialing the approved purtions of the piping system on the contractor's set of prints or by any other definite means mutually agreed upon. 


\section{APPENDIX D. 10 ADMINISTRATIVE}




\section{FOSTER WHEELER}

PROCESS PLANTS DIVISION
PLANT COMPLETION

INDEX:

JOB SPECIFICATION 60863-96AI
I. SCOPE

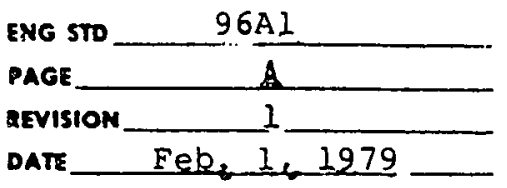

Page

1

1

2

A. Vendor and Service Assistance

B. Leak and Pressure Tests

C. Inspection

D. Permits

E. Removal of Rust Preventives

F. Operating Supplies and Chemicals

G. Iubricants

H. Rotation and Alignment

$\mathrm{J}$. Packing and Seals

K. Safety Derlces

L. Flushing and Chemical Cleaning

M. Temporary Strainers, Screens and Blinds

N. Drying Out

P. Purging

Q. Maintenance and Spare Parts

R. Housekeeping

S. Tie-ins at Unit Limits

T. Instructions

J. Removal of Temporary Bracing, Supports, etc.

IV. SPECIFIC PROCEDURES

A. Electrical Power and lighting Systems

B. Instrument, Systems

C. Piping Systems

D. Vessels

E. Shell and Tube Exchangers

F. Air Cooled Exchangers

G. Fired Heaters

H. Pumps, Compressors, and Drivers

J. Miscellaneous Equipment

K. Boilers

L. Water Treating Plants

M. Water Systems

N. Waste Disposal, Flares, and Stacks

P. Euildings and Accessories
3

3

3

4

4

4

5

5

11

11

14

14

15

15 
FOSTER WHEELER

PROCESS PLANTS DIVISION

ENG STO $\frac{96 \mathrm{Al}}{1}$
PAGE $\frac{1}{\text { REVISION }}-\frac{1}{\text { Feb, } l_{R} 1979}$
DATE

I. SOOPE

This standard is intended to define when the responsibility for care, custody and control of various units, systems or facilities of a plant is transferred from Foster Wheeler to the Client. The general principles differentiating the limits and responsibilities for the work for both parties are defined and a tabulation of the specific work performance responsibilities required to place common process equipment or systems into operation is presented.

II. DEFINITIONS

This section presents definitions which, along with the General and

(1) Spocific Procedures given in Paragraphs III and IV, serve to clarify the basic principles associated with the transfer of responsibility from the contractor to the client at comissioning tims.

A. Pre-comissioning. Pre-combissioning activities are the nonoperating adjustments and cold alignment checks made by the contractor as detailed in Paragraphs III and IV.

B. Ready for Comissioning. The date when the plant or part thereof is "ready for conmissioning" occurs when the plant, unit or facility or part thereof has been erected in accordance with drawings, specifications, and applicable codes, to the extent necessary to permit commissioning, and pre-conmissioning activities have been completed by contractor as dotailed in. Paragraphs III and IV.

C. Commissiontng. Basically, comissioning activities are associated with the running or operating of the plant and are the cilient's responsibilities unless specifically directed otherwise by the contract.

The commissioning period by the Client follows the completion of the pre-comissioning activities performed by Foster wheeler. During commissioning, the Client makes operating adjustments required before the plant may be satisfactorily operated, and commences operation of the plant or part thereof, performing any further adjustments, settings, etc.., that may be required.

D. Completion of Construction. Completion of construction means that the contractor has:

1. Provided erection in accordance with drawings and specifications.

2. Completed pre-comissioning work.

3. Completed final cleanup, painting, and thermal insulation work. 


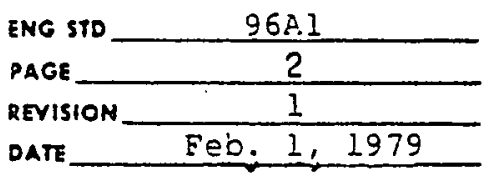

\section{GENERAL PROCEDURES}

General work procedures tabulated in Table I outline the work to be performed by Foster Wheeler and by the Client. Procedures applicable to specific systems or items of equipment are separately covered in

(1) Paragraph. IV. 


\section{FOSTER FA WHEELER \\ PROCESS PIANTS DIVISION}

ENG STD
PAGE $\frac{96 \mathrm{~A}\}}{3}$
REVISION $\frac{1}{\text { DATE }}$

III. GENERAI PROCEDURES

TABLE I

\begin{tabular}{|c|c|c|}
\hline Item & By Foster Wheeler & By Client \\
\hline $\begin{array}{l}\text { A } \\
\text { Vendor and } \\
\text { Service } \\
\text { Assistance }\end{array}$ & $\begin{array}{l}\text { Obtain manufacturer's (vendor) } \\
\text { assistance when deemed necessary } \\
\text { to render a satisfactory install- } \\
\text { ation, as mutually agreed between } \\
\text { Foster Wheeler and the client. }\end{array}$ & $\begin{array}{l}\text { Obtain manufacturer's (vendor) } \\
\text { assistance if desired, for } \\
\text { operating, or run-in by the } \\
\text { client's operating and } \\
\text { maintenance personnel; and } \\
\text { for training, or other } \\
\text { informational and operating } \\
\text { purposes. }\end{array}$ \\
\hline $\begin{array}{l}\quad \text { B } \\
\text { Leak and } \\
\text { Pressure } \\
\text { Tests }\end{array}$ & $\begin{array}{l}\text { Make non-operating field leak } \\
\text { or pressure tests on plping and } \\
\text { field fabricated equipment. AIl } \\
\text { testing will be conducted in accorad } \\
\text { ance with ENG STD } 89 \mathrm{Al} \text {. } \\
\text { Dispose of any special test media } \\
\text { in accordance with Client instruc- } \\
\text { tions. } \\
\text { Notify Client of test schedule. }\end{array}$ & $\begin{array}{l}\text { Drovide any special media } \\
\text { for test purposes and facil- } \\
\text { ities for disposal. } \\
\text { Witness tests when notified } \\
\text { by Foster Wheeler. } \\
\text { Conduct all operational } \\
\text { tightness testing. }\end{array}$ \\
\hline $\begin{array}{c}\text { C } \\
\text { Inspection }\end{array}$ & $\begin{array}{l}\text { Provide inspection oi the plant } \\
\text { to check conformity of erected } \\
\text { facilities to flow diagrams, } \\
\text { construction drawings, vendor } \\
\text { prints, and specifications. } \\
\text { Shop inspected equipment will not } \\
\text { be reopened for inspection in the } \\
\text { field except as specifically noted } \\
\text { in Paragraph IV.D. }\end{array}$ & $\begin{array}{l}\text { Provide for special inspec- } \\
\text { tions such as required by } \\
\text { insurance or govermental. } \\
\text { agencies and obtain required } \\
\text { approvals. } \\
\text { Perform shop inspection as } \\
\text { desired. } \\
\text { Verify and approve plant } \\
\text { check with any exceptions } \\
\text { noted on a separate work } \\
\text { order list (punch list). }\end{array}$ \\
\hline & & \\
\hline
\end{tabular}




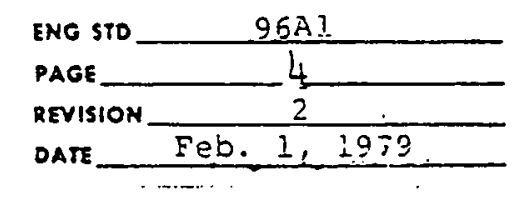

III. GENEILL PROCEDUPAS

TABLE I (contd)

(2)

(2)

(i)

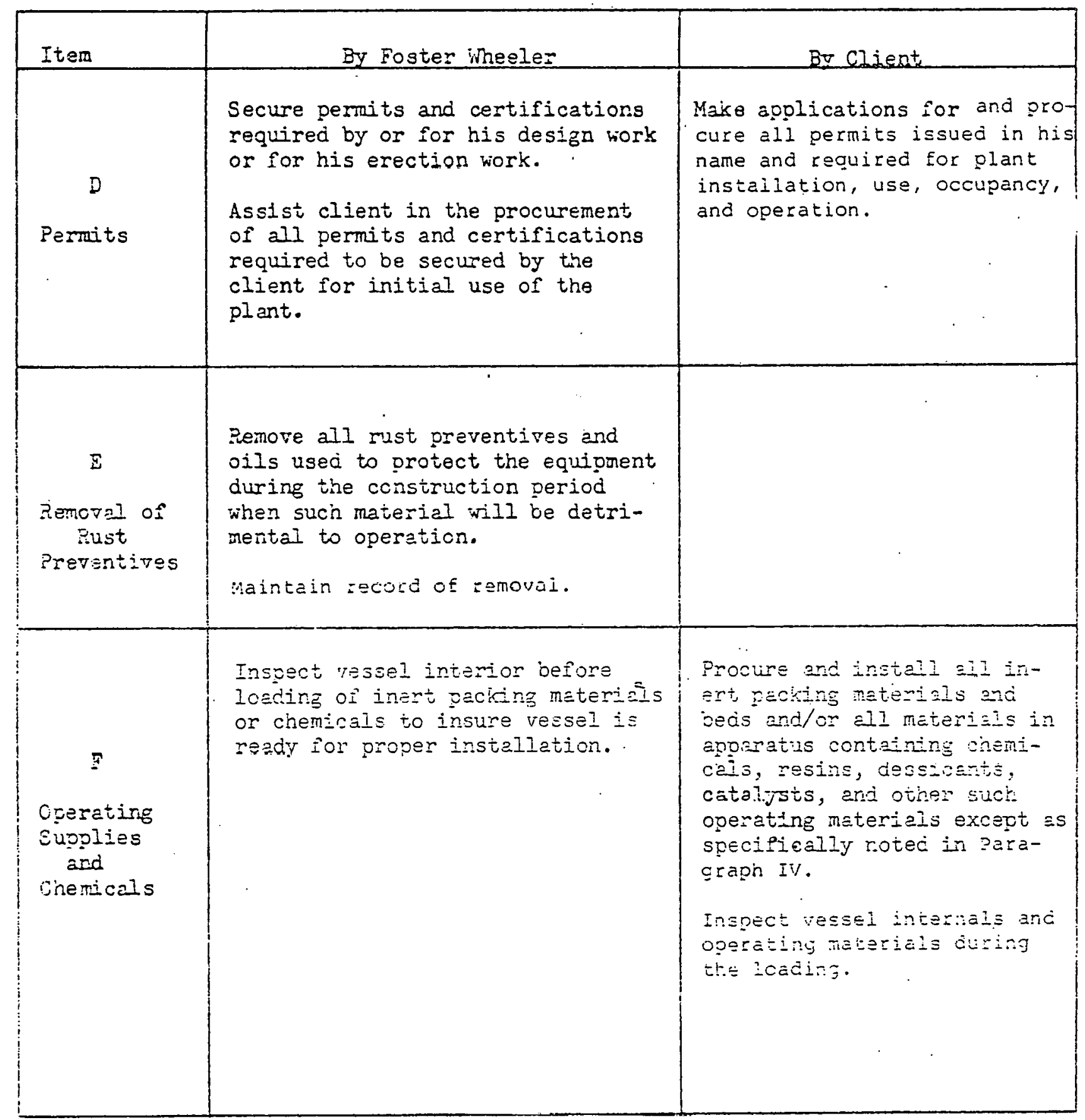


FOSTER

WHEELER

PROCESS PLANTS DIVISION

ENG STD
PAGE
REVISION
DATE

III. GENERAL PROCEDURES

TABLE I (contd)

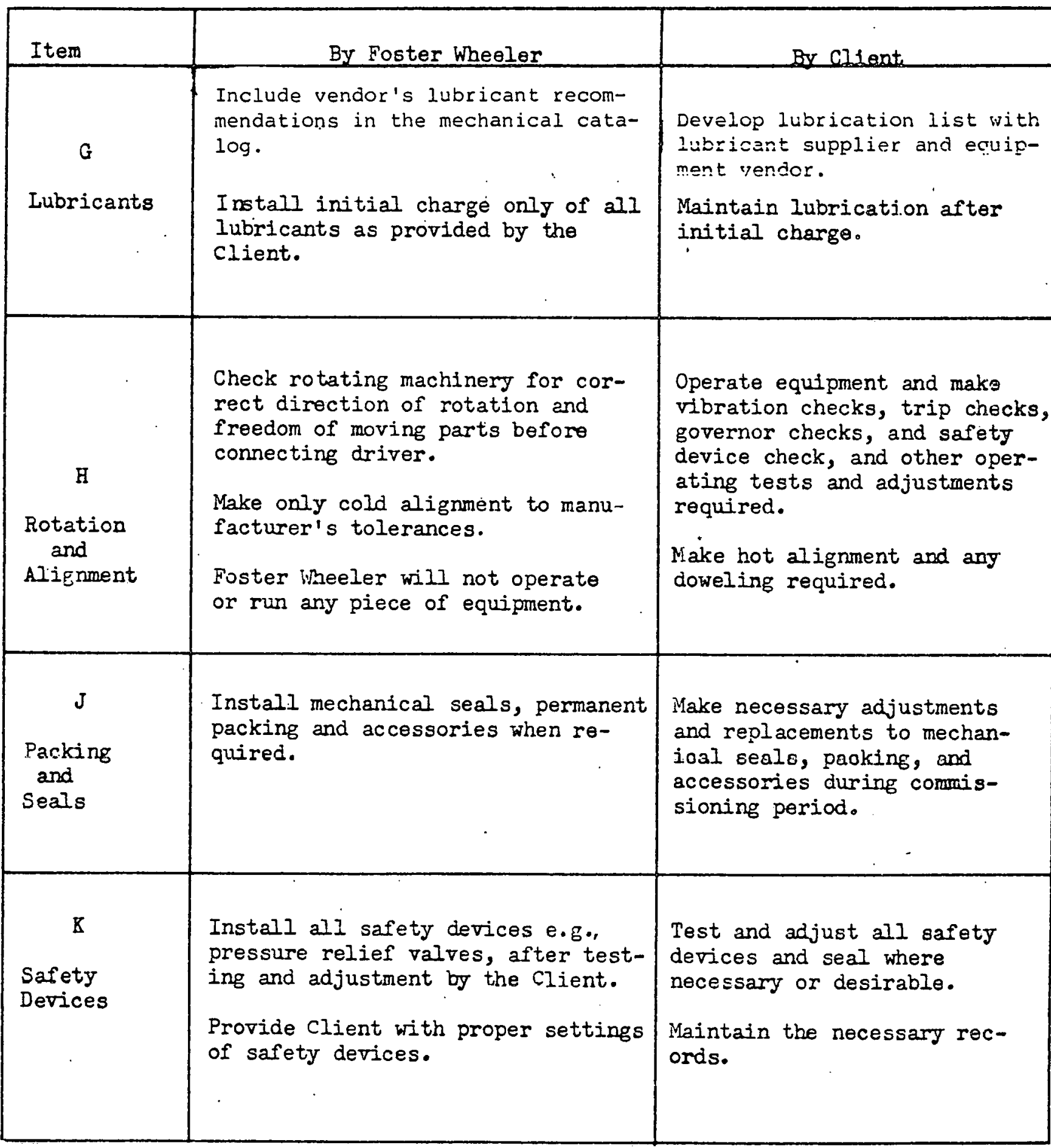




ENG STO $\frac{96 A 1}{6}$
PAGE
REVISION
DATE

III. GENERAL PROOCEDURES

TABIE I (contd)

\begin{tabular}{|c|c|c|}
\hline Item & By Foster theeler & By Client \\
\hline $\begin{array}{l}\text { L } \\
\text { Flushing } \\
\text { and } \\
\text { Chemical } \\
\text { Cleaning }\end{array}$ & $\begin{array}{l}\text { Turn systems over to the client free } \\
\text { of trash and construction debris } \\
\text { (not necessarily free of welding } \\
\text { slag.) }\end{array}$ & $\begin{array}{l}\text { Conduct all flushing, blowing } \\
\text { and chemical cleaning opera- } \\
\text { tions and provide circulating } \\
\text { media and chemicals required } \\
\text { except as noted in paragraphs } \\
\text { IV.B, IV.G, and IV.H. Dispose } \\
\text { of any resulatant wastes and } \\
\text { cleaning media. }\end{array}$ \\
\hline $\begin{array}{l}\quad M \\
\text { Teruporary } \\
\text { Strainers, } \\
\text { Screens } \\
\text { and } \\
\text { Blinds }\end{array}$ & $\begin{array}{l}\text { Provide and install all required } \\
\text { temporary strainers. }\end{array}$ & $\begin{array}{l}\text { Clean strainers as raquired } \\
\text { during circulation and re- } \\
\text { move when warranted. } \\
\text { Provide, install, and remove } \\
\text { all blinds required for } \\
\text { Mushing or operation. } \\
\text { Maintain required records. }\end{array}$ \\
\hline $\begin{array}{c}\mathrm{N} \\
\text { Drying out }\end{array}$ & $\begin{array}{l}\text { Dry out when required to complete } \\
\text { further construction or where } \\
\text { facilities supplemental to those } \\
\text { required for nomal operation are } \\
\text { needed. }\end{array}$ & $\begin{array}{l}\text { Dry out systems, refractories } \\
\text { and linings when such drying } \\
\text { can be accomplished with per- } \\
\text { manenily installed equigment } \\
\text { or as part of the comission- } \\
\text { activities. }\end{array}$ \\
\hline $\begin{array}{l}\text { P } \\
\text { Puging }\end{array}$ & Install purge connections. & $\begin{array}{l}\text { Provide purge materials and } \\
\text { conduct necessary purge } \\
\text { operations. }\end{array}$ \\
\hline
\end{tabular}


FOSTER

8

WHEELER

PROCESS PLANTS DIVISION

III. GENERAL PROCEDURES
PLANT COMPLETTON

ENG STD $\frac{96 \mathrm{Al}}{7}$
PAGE $\frac{2}{\text { REVISION } \frac{\text { Feb, 1, 1979 }}{\text { DATE }}}$

TABLE I (cont'd)

\begin{tabular}{|c|c|c|}
\hline Item & By Fester Theeler & By Client, \\
\hline $\begin{array}{l}Q \\
\text { Maintenance } \\
\text { and } \\
\text { Sparo } \\
\text { Parto }\end{array}$ & $\begin{array}{l}\text { Protect equipment from normal } \\
\text { weather conditions, corrosion, or } \\
\text { damage prior to commissioning. } \\
\text { Include vendors recommended spare } \\
\text { parts lists in Mechanical Catalogs. }\end{array}$ & $\begin{array}{l}\text { Provide adequate maintenance } \\
\text { for equipment, including such } \\
\text { items as the cleaning of } \\
\text { strainers and the repairing } \\
\text { of steam traps, after pre- } \\
\text { commissioning is complete. } \\
\text { liaintain adequate spare parts } \\
\text { and supplies. }\end{array}$ \\
\hline $\begin{array}{l}\text { R } \\
\text { Housekeeping }\end{array}$ & $\begin{array}{l}\text { Provide construction cleanup in- } \\
\text { cluding removal of excess materials } \\
\text { temporary facilities and scaffold- } \\
\text { ing, rough sweeping or raking the } \\
\text { area, and trash pickup. Washing } \\
\text { or further cleanup is not included. }\end{array}$ & $\begin{array}{l}\text { Maintain adequate housekeeping } \\
\text { practices after pre-comission- } \\
\text { ing is complete as required } \\
\text { for safe operation. }\end{array}$ \\
\hline $\begin{array}{l}\text { s } \\
\text { Tie-ins at } \\
\text { Unit Iimits }\end{array}$ & $\begin{array}{l}\text { Obtain client's approval and make } \\
\text { the necessary tie-ins at the unit } \\
\text { limits as required by the specifi- } \\
\text { cations. }\end{array}$ & $\begin{array}{l}\text { Prepare all systems for safe } \\
\text { tie-ins and observe same. }\end{array}$ \\
\hline $\begin{array}{c}\mathrm{T} \\
\text { Instructions }\end{array}$ & $\begin{array}{l}\text { Transmit to client any vendor's or } \\
\text { manufacturer's instructions and } \\
\text { drawings, as applicable. } \\
\text { Provide client with any special } \\
\text { instructions such as requirements } \\
\text { for drying liners. }\end{array}$ & $\begin{array}{l}\text { Maintain adequate vendor } \\
\text { instruction file so that the } \\
\text { information may readily be } \\
\text { retrieved as may be required. }\end{array}$ \\
\hline
\end{tabular}




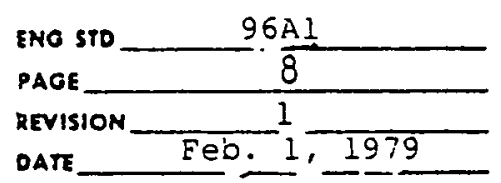

III. GENERAL PHOCEDURES

TABiE I ( contd)

\begin{tabular}{|c|c|c|}
\hline Item & By Foster Wheeler & By Client \\
\hline $\begin{array}{l}U \\
\text { Removal of } \\
\text { Terporary } \\
\text { Bracing, } \\
\text { Supports, } \\
\text { etc. }\end{array}$ & $\begin{array}{l}\text { Remove all temnorary supports, } \\
\text { bracing, or other foreign objects } \\
\text { which have been installed in equip- } \\
\text { ment to prevent demage during } \\
\text { shipping, storage, and erection. } \\
\text { e.g., ressels, transformers, rotat- } \\
\text { ing machinery, etc.. including other } \\
\text { items specified elsewhere for the } \\
\text { appropriate equipment type. }\end{array}$ & \\
\hline
\end{tabular}




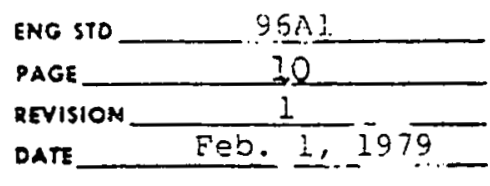

\section{SPECIFIC P SOCEDURES}

\begin{tabular}{|c|c|c|}
\hline Item & B耳 Fostar Wes:er & By nisient \\
\hline $\begin{array}{c}\text { B } \\
\text { Instmuent } \\
\text { Systems }\end{array}$ & 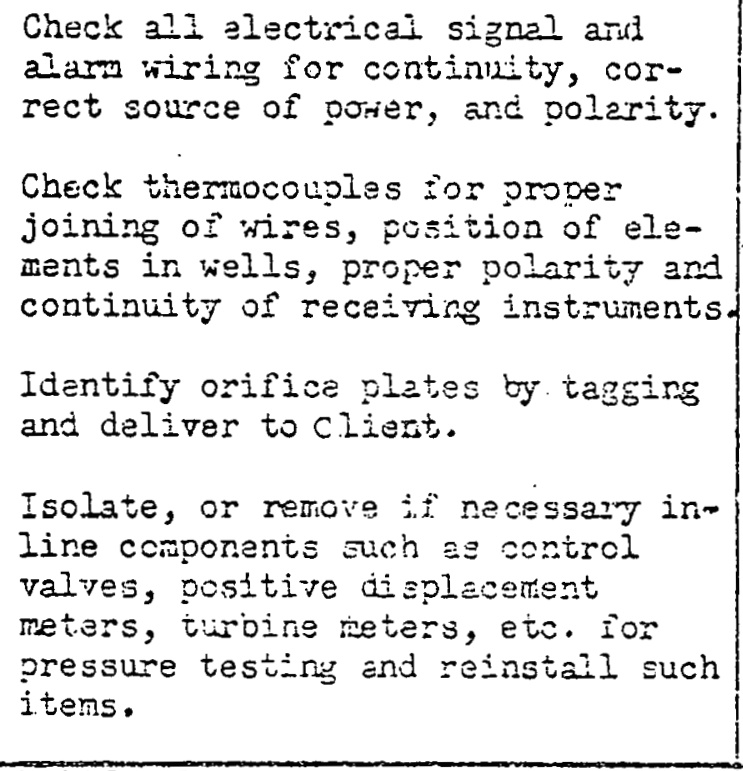 & 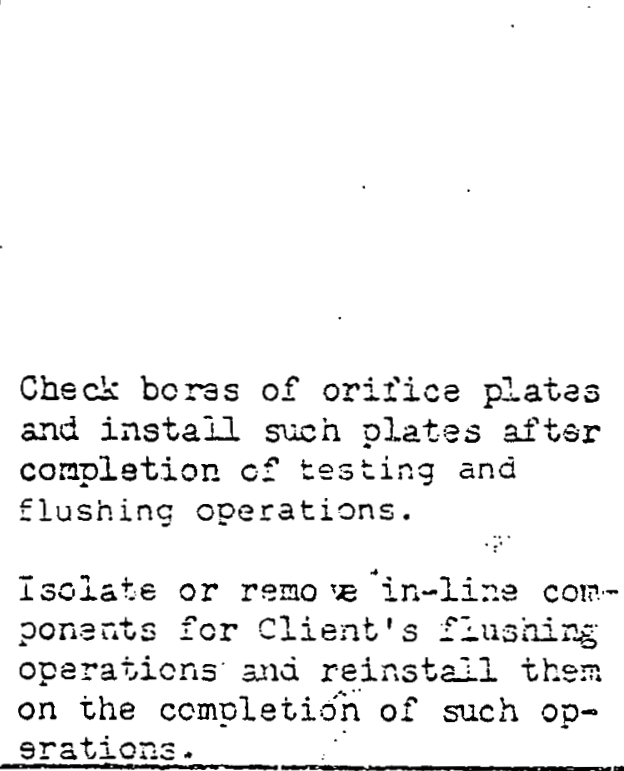 \\
\hline $\begin{array}{c}c \\
\text { Piping } \\
\text { Sjstems }\end{array}$ & 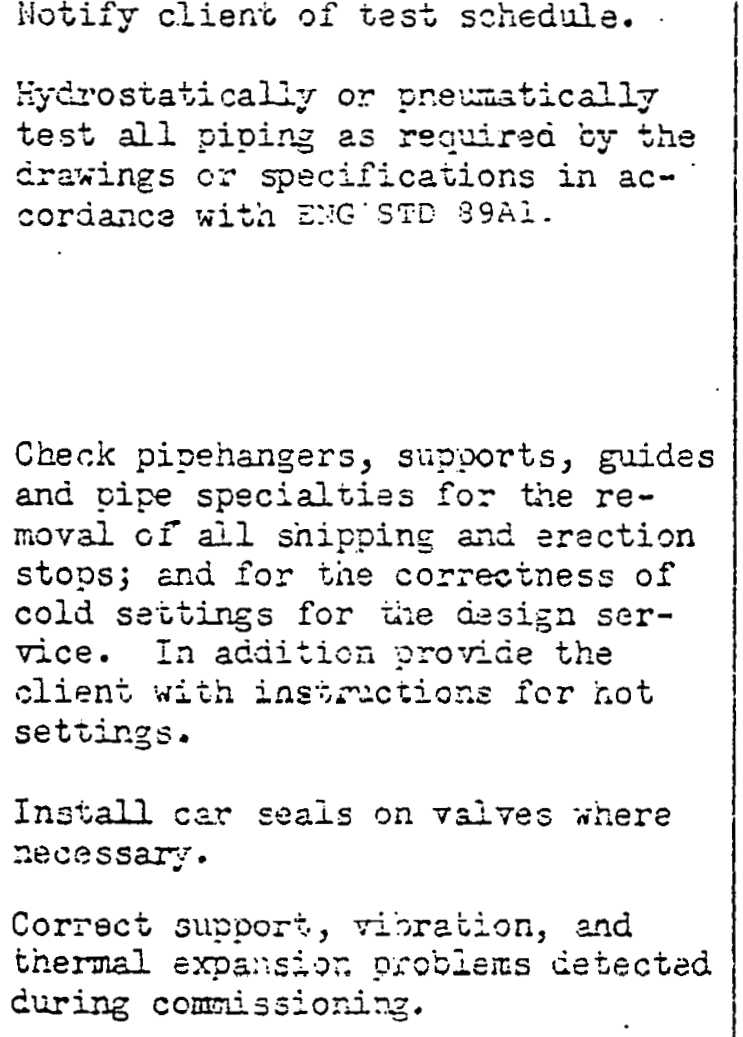 & $\begin{array}{l}\text { Check pipenangers, surports, } \\
\text { guides, and pipe speciaities } \\
\text { for hot settings and make } \\
\text { minor adjustments as ieces- } \\
\text { sart. } \\
\text { Check, record position, anc } \\
\text { identify all car sealed valves }\end{array}$ \\
\hline
\end{tabular}




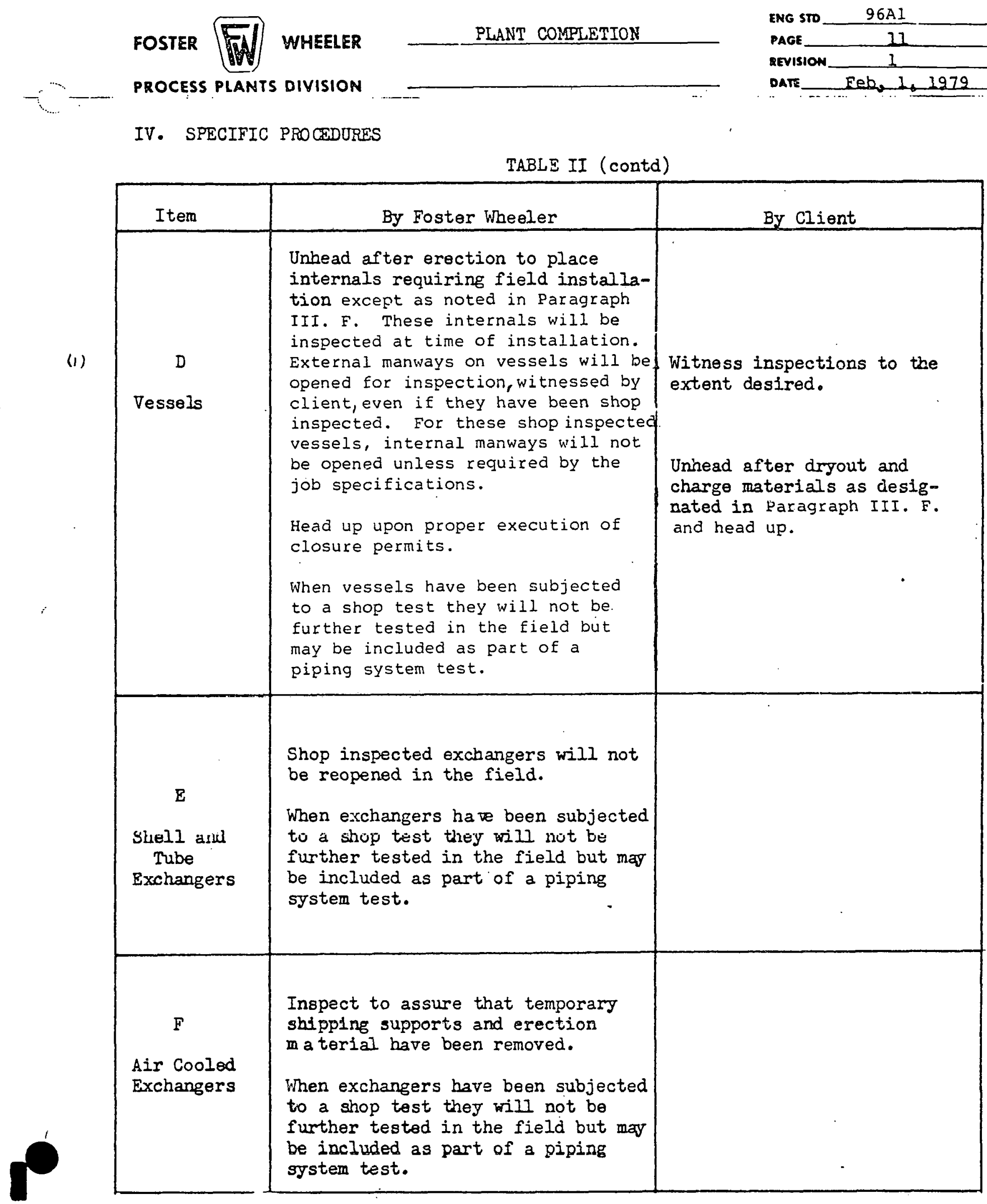




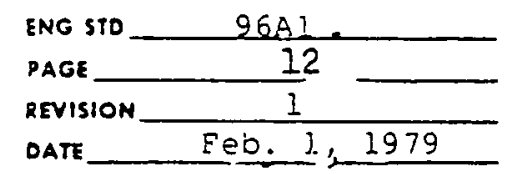

IV. SPECIFIC PROCEDURES

TABLEE II (cont, $\mathrm{d})$

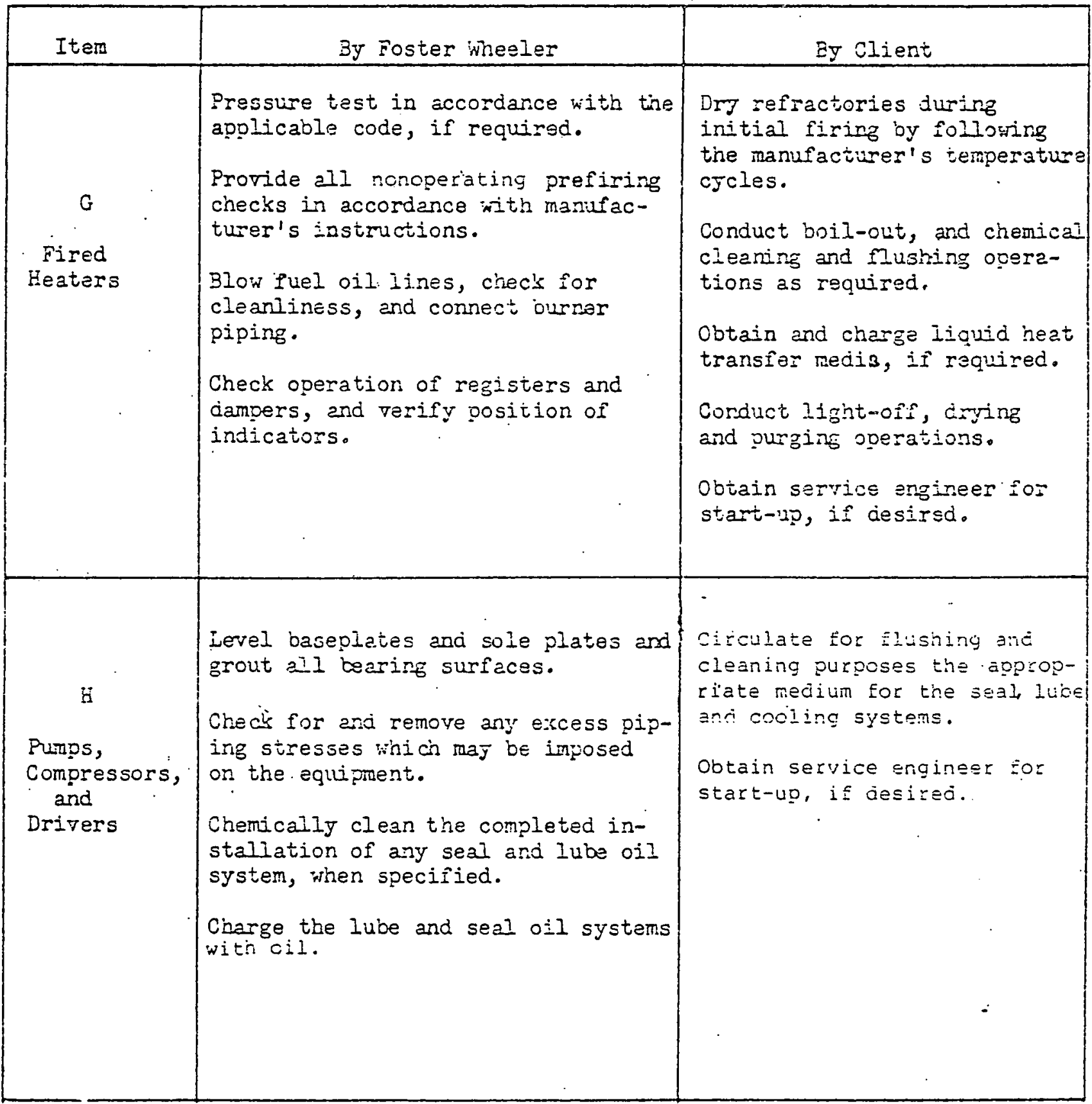


 \\ FOSTER

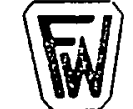 \\ WHEELER}

PLANT COMPLETION

PROCESS PLANTS DIVISION

IV. SPECIFIC PPOCEDURES

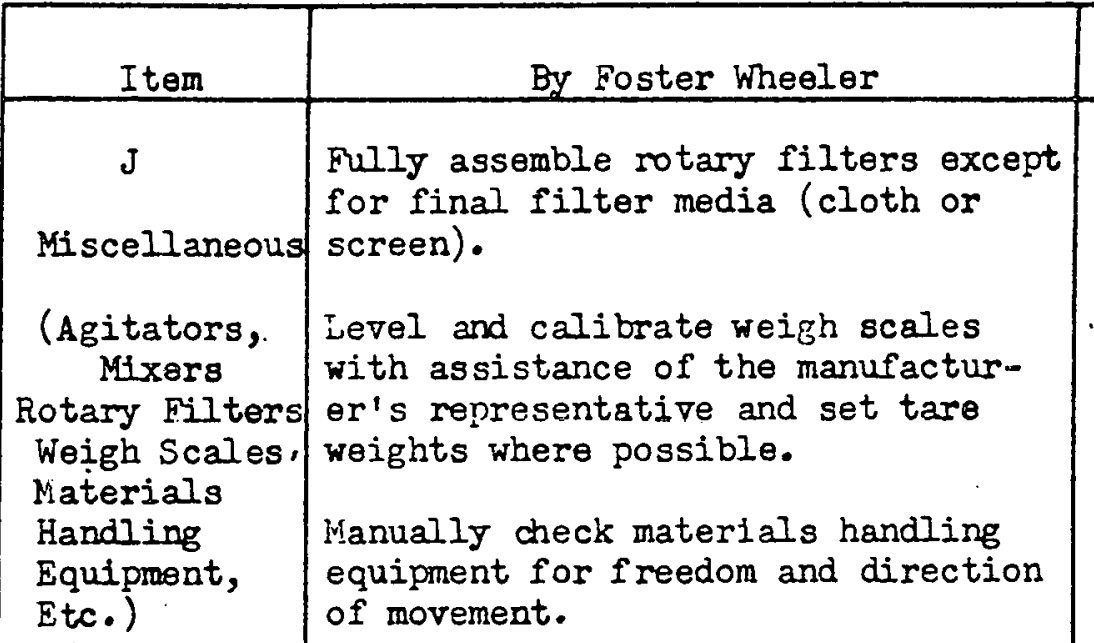

llake nonoperating pressure test in accordance with applicable codes,

K if required.

Boilers

Inspect installation for completeness and correctness of installation and make other nonoperating prefiring checks.

Check proper damper positioning and travel.

ENG STO $\frac{96 \mathrm{Al}}{13}$
PAGE
REVISION
DATE

Install all final filter media (cloth, pracoat, etc.)

Make all final adjustments during run-in and any performance tests required.

Obtain service engineer for start-up, if desired.

Dry refractories during initial firling by following the manufacturers temperature cycles.

Furge, flush, and drain steam mains as necessary.

Obtain and charge treatad water for boll-out and initial operation as required. Commission auxiliaries as detailed elsewhore under the appropriate equipment type.

Conduct boil-out and chemical cleaning and flushing operations, as required.

Conduct initial light-off. with associated checks and adjustments.

Obtain a service engineer for start-up, if desired.

Conduct all operating tests and obtain required certification. 


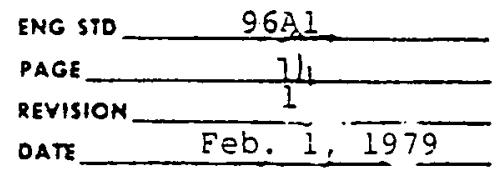

IV. SPECIFIC PROCEDUHTS

TARLE II (cortd)

\begin{tabular}{|c|c|c|}
\hline Item & By Foster hrneeler & $B y$ Cliant \\
\hline $\begin{array}{c}\text { L } \\
\text { Water } \\
\text { Treating } \\
\text { Placts }\end{array}$ & $\begin{array}{l}\text { Inspect for completeness and correct } \\
\text { ness of installations and mike ang } \\
\text { nonoperating checks which may be } \\
\text { required. } \\
\text { Provide and install initial charge } \\
\text { of ion-exchanse resins and inert } \\
\text { bed material. }\end{array}$ & $\begin{array}{l}\text { Make tire neceseary operating } \\
\text { tests and acjustments to } \\
\text { water treatment systems. } \\
\text { Pruvice all water treatment } \\
\text { chemicals except initial } \\
\text { charge of ion-axchange gesins. } \\
\text { Obtain services oi iater con- } \\
\text { sultant to acivise and monitor } \\
\text { the water treacment operation } \\
\text { as desirec. }\end{array}$ \\
\hline $\begin{array}{l}\text { : } \\
\text { Water systams } \\
\text { ( semrica } \\
\text { wells, cool- } \\
\text { ing towers, } \\
\text { sea water, } \\
\text { fire water, } \\
\text { etc.) }\end{array}$ & 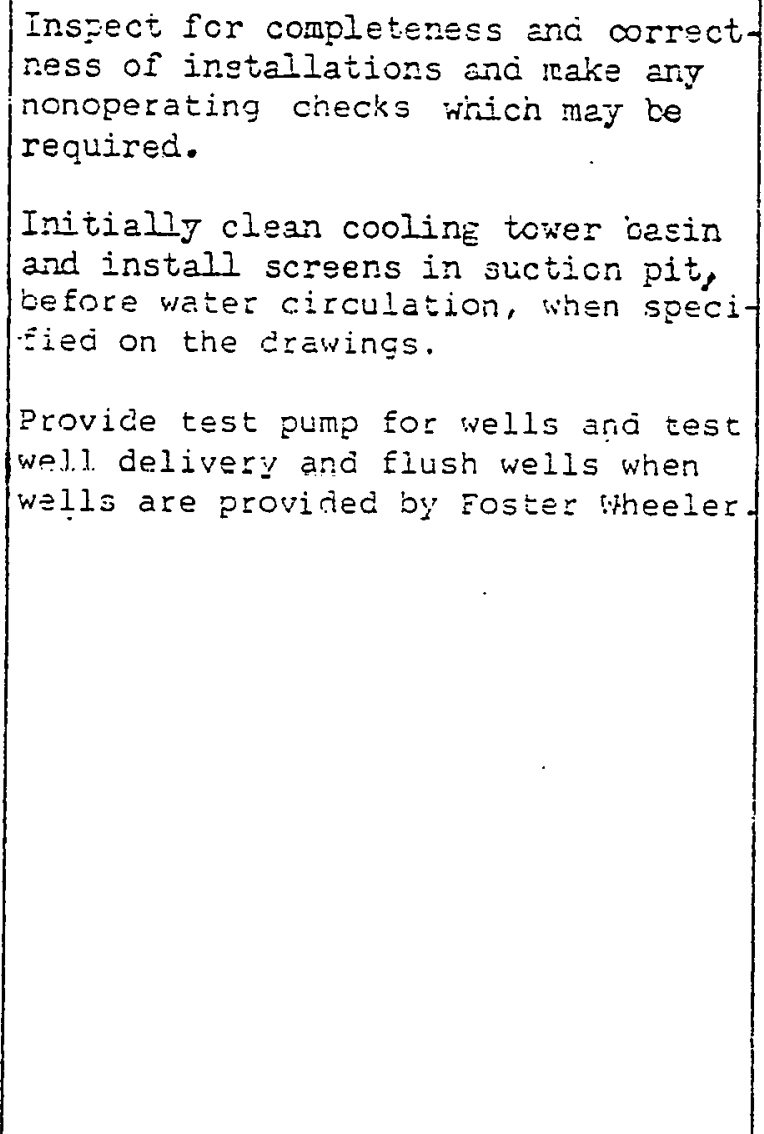 & 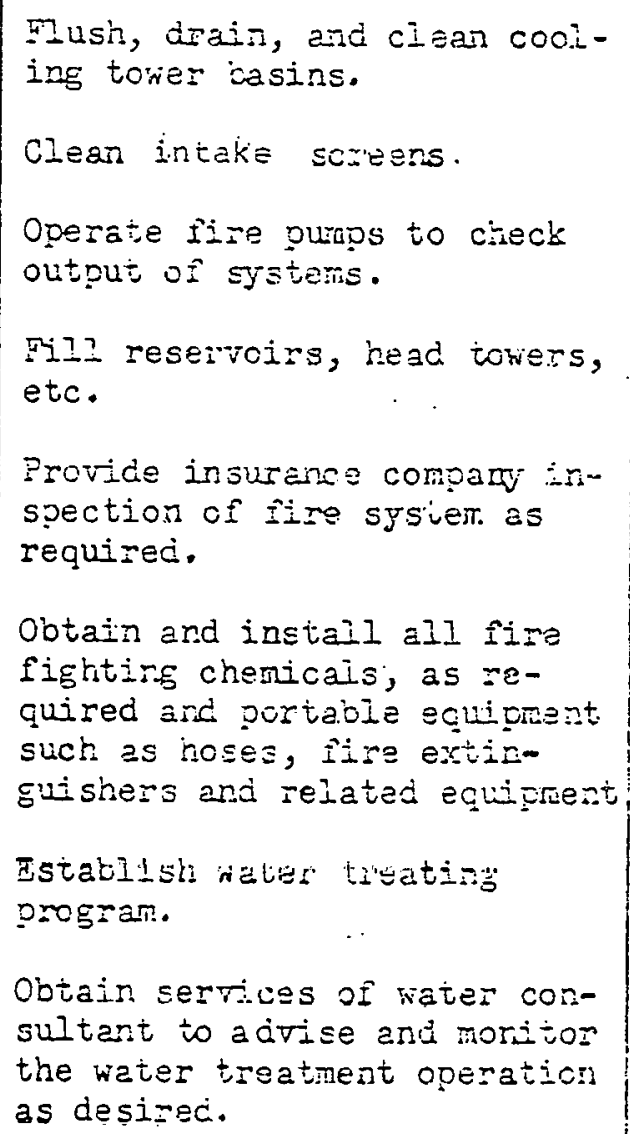 \\
\hline
\end{tabular}


FOSTER WHEELER

PROCESS PLANTS DIVISION

ENG STD
PAGE $\frac{96 \mathrm{~A}}{15}$
REVISIOA
DATE

IV. SPECIFIC PROCEDURES

TABLE II (contd)

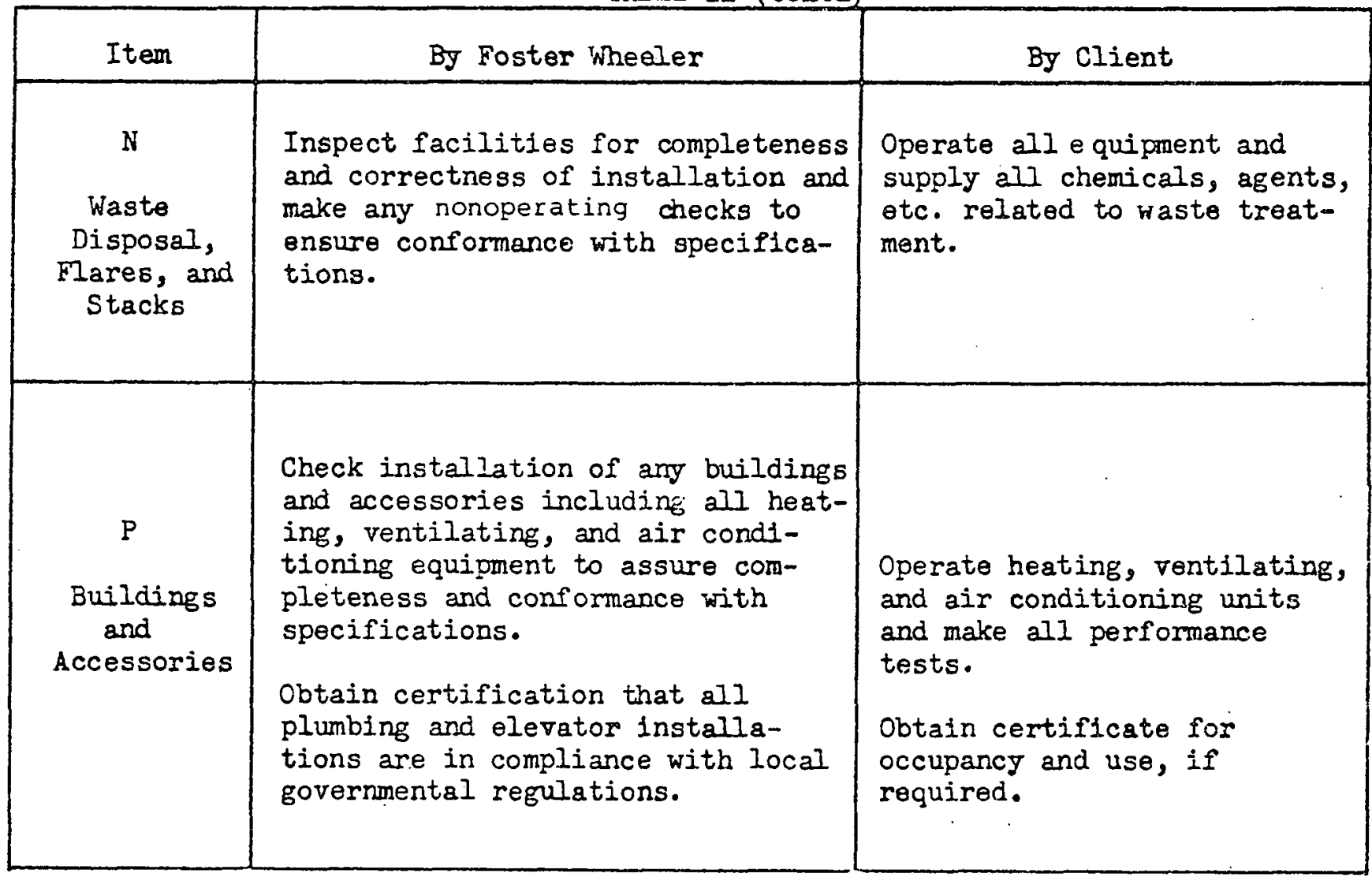


FOSTER WHEELER

PROCESS PLANTS DIVISION
PREPARATION OF MATERIAL FOR SHIPMENT

JOB SPECIFICATION $60863-97 \mathrm{AI}$
ENG STD 97AI

PAGE

REVISION 2

DATE Feb 1, 1979

REVISION INDEX

\begin{tabular}{rrl} 
EAGE & REV. & DATE \\
\cline { 2 - 3 } 1 & 2 & $2 / 1 / 79$ \\
2 & 1 & $2 / 1 / 79$ \\
3 & 1 & $2 / 1 / 79$ \\
4 & 1 & $2 / 1 / 79$ \\
5 & 2 & $2 / 1 / 79$ \\
6 & 2 & $2 / 1 / 79$ \\
7 & 1 & $2 / 1 / 79$ \\
8 & 1 & $2 / 1 / 79$ \\
9 & 2 & $2 / 1 / 79$ \\
10 & 2 & $2 / 1 / 79$ \\
11 & 1 & $2 / 1 / 79$
\end{tabular}




\section{FOSTER

RNO STD
REVISION
DATE Feb, 1, 1979 - 1972

\section{SCOPE}

A. This specification covers the essential instructions for proper preparation and packaging of equipment, materials and supplies to insure delivery in satisfactory condition regardless of destination. All shipments, whether scheduled for immediate use or for delivery to storage, shall comply with these requirements and instructions.

B. Any deviation from this specification must have the prior approval of Foster Wheeler. This specification is applicable to prime vendors and all sub-vendors.

C. Information and specifications stated in the inquiry, material requisition, or purchase order shall TAKE PRECEDENCE over the requirements set forth herein.

II. FURPOSE

The requirements are specified so that material as shipped will endure the rigors of:

A. Handling, stacking and transport to plant construction site.

B. Outdoor storage for a period of twelve (U.S.A. and Canada) jobsites and eighteen months on Domestic Export jobsites (including Alaska and Hawaii).

C. Outdoor weather exposure from the time equipment is uncrated and set on its foundation until plant start-up which may be as much as one year later. This general requirement may not apply to all equipment; e.g. pumps and compressors (particularly nonlubricated) for which vendor's bid shall propose for Purchaser's consideration and approval recommended methods and materials of preservation, allowable exposure time and other necessary requirements.

\section{TYPE OF PACKAGING}

A. The type of packaging to be used is best determined by the vendor and may consist of boxing or crating, bundles, bags, fibreboard boxes, barrels, metal drums, or merely skids. The selection should be based upon suitability to the type of material to be packed and cost.

B. Table A is a guide which tabulates methods of packing acceptable for categories of material as well as destination. Final selection for each project shall be given in the inquiry, material requisition or purchase order. 
ENG STD $97 \mathrm{AI}$

PAGE 2

REYISION 1

DATE Feb. 1, 1979
FOSTER HA

WHEELER

PROCESS PLANTS DIVISIOA

\section{PREPARATION OF MATERIAL}

A. All equipment and material shall be cleaned internally and externally to remove all weld spatter, scale, rust, cuttings, filings, etc., as well as any and all foreign material.

B. Critical wearing surfaces, highly stressed parts, and highly finished surfaces shall be further cleaned by dipping or brushing with a suitable solvent, such as petroleum naphth or alkaline cleaning compound. Critical functioning or close tolerance surfaces shall be additionally cleaned to insure removal of perspiration and ifingerprint stains, using any commercially available oil fingerprint remover.

C. After hydrotesting, operation, and/or performance test, all fluids, i.e., lubricating oil, fuels, water, etc. shall be compietely drained from all tanks, vessels, jacketing, piping, etc. and wiped or blown dry. Iint free rags shall be used for wiping.

\section{PRESERVATION}

\section{A. Painting}

1. Primer and Pinish coat shall be applied only when specified by painting JOB STANDARD.

2. Cast machinery shall be given at least one coat of primer and one coat of paint. Paints which comoine a primer with the finish coat are acceptable and one coat of such paint is sufficient. In any case, both primers and paints shali be suitable for a minimum of $50^{\circ} \mathrm{F}$ more than the design temperature as specified on the requisition.

3. Smooth surfaces such as fabricated sheet metal, blower casings, etc. musl have separate coato of primer and paint, (minimum of one coat of each). However, corrosion resistant materials such as stainless steel shall not be primed nor painted.

4. Do not apply filler to cast surfeces or weldments.

5. Masking tape apolied to such items as gage glasses, rameplates, ote., shall be left in place after painting.

6. External machined or highly finished surfaces, extemal rotating or reciprocating shafting, packed valve stems and linkages must be kept free irom paint. 


\section{FOSTER \\ 河 \\ WHEELER \\ PROCESS PLANTS DIVISION}

PREPARATION OF MATERTAL

FOR SHIPMENT
ENG STO $\quad 97 \mathrm{AL}$

PAGE_ 3 .

REVISION Feb. $\frac{1}{1}, 1979$

\section{PRESERVATION (continued)}

B. Rust Prevention

AIl unpainted machined metal surfaces, both external and internal shall be cleaned and dried as specified above, and amply coated with a rust preventative which will maintain a protective coating for a minimum of twenty-four months provided the coating is not burned, dissolved or mechanically rubbed off.

1. For surfaces which are external, the rust preventative should be a heavy application of grease or liquid film which dries to a tough coating and which conforms with the performance requirements of U.S. Defense Department Specifications for Preservatives as listed below:

$$
\begin{aligned}
\text { Spec. Designation - } & \text { Mil-C-11796 Class } 1 \\
\text { Application Method - } & \text { Hot application, brush or dip, } \\
& \begin{array}{l}
\text { maximum temperature of appli- } \\
\text { cation } 200^{\circ} \mathrm{F} .
\end{array}
\end{aligned}
$$

Description and Use - Thick, hard drying, greasy film. For protection of highly finished parts of simple design for long periods.

Acceptable preservatives are available from the major oil companies and their dealers, for example:

Gulf
Esso (Enjay Chem.)
Shell
Mobil
Texaco
Valvoline

Gulf No-Rust \# I

Rust-ban 385

Ensis 264

Mobilcoat 601

Texaco Rust-Proof Compound I Tectyl 506

Other brands are available and are acceptable providing they conform with the performance requirements above.

2. For internal machined surfaces of an assembled unit, the rust preventative should be of a type which does not require removal before operation of the equipment and which conforms with the performance requirements of U. S. Defense Department Specifications for Preservatives as listed below: 


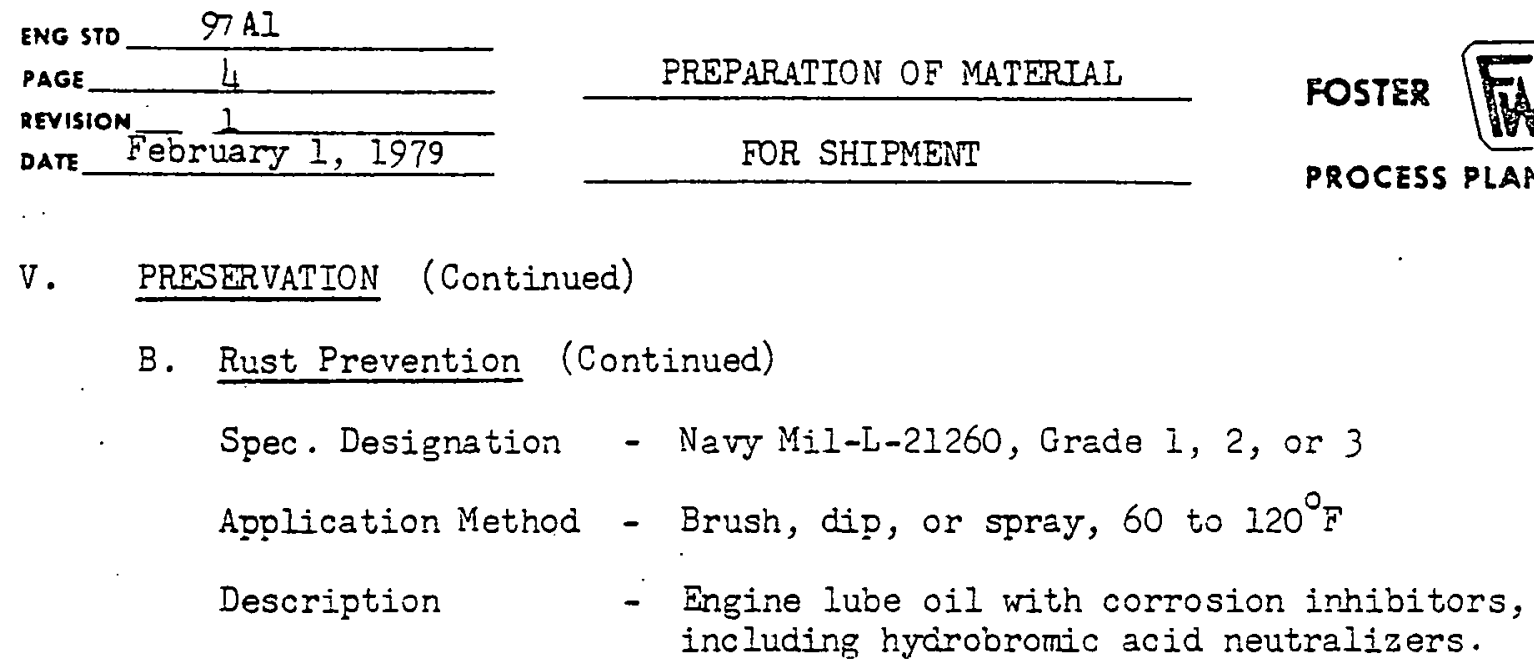

Acceptable preservatives are available from the major oil conpanies and their dealers, for example:

Gulf

Shell

Mobil

Texaco

Esso (Enjay Chem.)
Gulf No-Rust Engine $O_{i j}$. Grade 2 or Nox Rust 3IOAC Ensis Engine Qil Grade 20 Mobilicat. - 501 or 503 Preservative 0 il 10 hi Rustban \# 623

Other brands are available and are acceptable, providing they conform with the performance requirements above.

Acceptable methods of applying rust preventative are spraying, brushing, filling, flushing, etc. through all available openings, or by disassembly if necessary, to completely coat and protect all unpainted internal surfaces. Particular attention should be paid to journal surfaces of sleeve bearings and complete enti-friction bearings, so they are completely coated.

3. The manufacturer shall wire a large red tag to the machine which states: "Caution - This equipment has been treated with a rust preventative and no parts should be disturbed until ready to place in service. If protective coating film is broken, it should be restored for continued storage".

4. Any piping disassembled from equipment for ease of shipment shall. have internal surfaces cleaned free of scale and all other foreign matter and coated with a rust preventative which conforms with Navy Mil-I-21260, Grade 1, 2, or 3 per Parasraph $\% .3 .2$. above. Pickling and cleaning per Engineering Standard $50 \mathrm{~A} 6$ is also acceptable. In either case, all pipe ends shall be securely sealed with moistureproof paper and wooden flange covers or metal oape. 


\section{FOSTER WHEELER \\ PROCESS PLANTS DIVISION}

PREPARATION OF MATERIAL

FOR SHIPMENT

ENG STO $97 \mathrm{~A} 1$

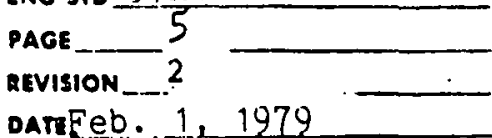

V. PRESERVATION (Continued)

B. Rust Prevention (Continued)

5. After application of rust preventative, exposed machined surfaces shall be wrapped with a heavy "VPI" treated paper, or other heavy waterproof paper (or plastic) enclosing "VCI" (Vapor Corrosion Inhibitor) crystals. In all cases, $\mathrm{pH}$ of wrapping shall be neutral. The wrapping shall be secured tightly with tape or twine. Sharp edges shall be cushioned to prevent puncture of wrapping.

Spare parts and replacement parts shall be covered with a second wrapping of heavy waterproof paper.

6. Because of possible damaging effect, care should be exercised in applying must preventatives lest items fabricated of leather, mubber, mica, and similar i.tems be coated with the preservative compound.

c. Protection of Openings

1. Flanged openings shall be protected with bolted-on wooden outdoor plywood (min. $\frac{1}{4}$ thickness) or metal covers, using at least three bolts. (Wiring-on covers is not acceptable). A sealer, Permatex No. 2 or equal, shall be used between the flange and the cover. After openings have been covered, the joint shall be wrapped with waterproof tape.

2. Porous bags filled with dessicant shall be hung on the inside of the wooden or metal bolt-on covers on all major connections of rotating equipment unless physical size is restrictive.

3. Unconinected pipe threads used in normal operation shall be closed with threaded metal plugs or caps. These shall be identified with metal tags explaining purpose and/or providing connection number used on Foster Wheeler and vendor's drawings. 


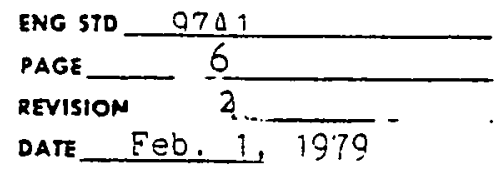

FOSTER

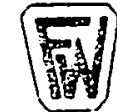

WHEELER

V. PRESERVATION (Continued)

C. Protection of Openings (Continued)

4. All closures that are part of original equipment shail be tight fitting.

5. Plastic closures and thread protectors are specifically prohibited unless their use receives prior approval from Foster Wheeler.

D. Flexible Connections

All flexibie connections subject to possible damage during shipment shall be disconnected and loose ands adequately supported or protected to prevent damage.

E. Shaft Couplings

Flexible couplings shail be broken and adequately supported and orotected to prevent damage. Rigid couplings shell be in accordance ith the manufacturer's recommendation, as required to provide fuil protection and safety in transit and storage.

F. Dehydration

1. The use of desiccant crystals within an enclosed piece of equipment is of particular importance in high humidity areas subject to wide variation in temperature over a twenty-four (24) hour period. Location of desiccant should be at suitable internals to provide uniform distribution.

2. The quantity of dehydrating agent to be used shall be determined on the basis of the surface area of the moisture barrier, the moisture vapor transmission rate, and the volume of the enclosed soace. Additional dasicsant shnnli he used if otiner moistureabsorbing dunnage or supoorting structures are included within the enclosed volume.

3. All equipment shipped utilizing denytrating materials shall be labeled or tagged with an easily observed red sign, reading: "Caution - Desiccant materiais are enclosed within this equipment. Do not operate jefore removing. Should the integritiy of the enclosure be broken before operation, the desiccant must be reolaced and the enclosure resealed for continued storage". 
FOSTER

PROCESS PLANYS DIVISION
PREPARATION OF MATERIAI

FOR SHIPMENT

VI. SHIPPING ENCLOSURE

A. Domestic Shipment

1. Very large and complicated machinery such as compressors, generators, large motors, engines, pressure vessels, etc. not supplied with self-supporting baseplates, shall be bolted to a skid formed of heavy timbers suitable for sling lift or fork lift truck handling, as applicable. This equipment shall be wrapped with heavy waterproof paper, heavy plastic, or tarpaulin so as to be enclosed on top and sides and ventilated underneath to permit air circulation. This covering shall be secured to the skid or baseplate in such a manner that it will not extend beyond the outside edge and thus be torn when a sling or fork lift handies the equipment.

Equipment supplied with lifting lugs or specific directions for lifting shall have such identification or instructions stenciled or securely affixed at prominent locations.

2. Very large and/or complicated equipment mounted on selfsupporting baseplates will not require skids. Coverings shall be as listed in the preceding paragraph.

3. Medium or small size equipment whether on self-supporting baseplates or not, shall be bolted to skids formed of timbers suitable for sling lift or fork lift truck hendling. AII equipment shall be wrapped with heavy waterproof paper or plastic, so as to be enclosed on top and sides but ventilated underneath to permit breathing. This covering shall be securely attaohod to the cquipment with tape, twine, or staples.

This equipment, if required, shall then be enclosed within a wooden crate or box of ample size and strength to protect the equipment (including affixed piping and accessories) against damage during transportation and handling at the jobsite.

4. Bulk materials may be bundled, enclosed in burlap sacks, waterproof bags, waterproof fibre box, fibre drums, or metal drums. The type of material will govern the best method for shipment. Shipment shall then be palletized in convenient quantities. 


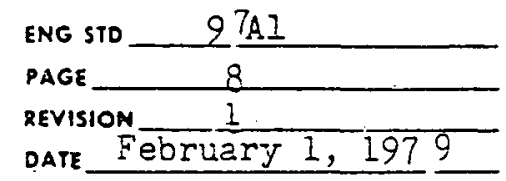

\section{PREPARATION OF MATERIAL}

FOR SHIPMENT
FOSTER

PROCESS PLANTS

\section{SHIPPING ENCLOSURES}

A. Domestic Shipment (Continued)

5. Piping may be shipped as loose pieces except that all piping $2^{\prime \prime}$ and smaller shall be oundled and strapped in order to make more rigid structures for shipment.

Piping snall be consolidated as required by Foster Wheeler for shipment. Any piping specially cleaned internally prior to shipment shall have ends capped or taped to make them watertight, and shall be desiccant protected.

6. When equipment is shipped in a "blocked-up" condition the requirements of Paragraph VI-B2-C below shall also apply.

B. For Overseas Export Shipment

1. In general, ali equipment shall be enclosed in nailed, wooden boxes supplemented with steel strapping. Crating shall be of adequate strength to permit stacking. The crate shall be reinforced with steel strapping.

2. Box Construction

a. Waterproof paper shall be used to line top, ends, and sides of ali boxes.

b. Each box shall be equipped with screened vent openings of a size commensurate with size of box located on the sides with internal splash boards, so as to prevent entrance of rain as well as to prevent sweating from fluctuations in temperature.

c. Any finish machined part that is blocked for shipment using wood chocks or wood framing shall be isolated from the wood using copper sheathing or some other moisture impervious material to prevent moisture penetration from the wood through to the metal surface.

3. Large volume equipment such as pressure vessels, large machinery pieces, structural steel, large size pipe, eic., which are inherentiy weather resistant and capable of withstanding the rigors of transportation may be shipped without being boxed. 
FOSTER

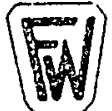

WHHEELER

PROCESS PLANTS DIVISION
PREPARATION OF MATERIAL

FOR SHIPMENT

VI. SHIPPING ENCLOSURES (Continued)

B. For Overseas Export Shipment (Continued)

4. Any equipment containing stainless steel parts must be boxed and marked: "This material to be stored below deck and not as deck cargo".

5. Any special shipping fixtures, tarpaulins, etc. are considered to be expendable items and will not be returned to supplier.

VII. SMALL LOOSE PARTS

Small loose parts shall be packed in a separate, sturdy wood box with steel strapping \& each part marked with waterproof ink for proper identification. Any such box may be shipped with the main equipment, provided that it is securely attached to the main skid or within the main box. Secure attachment consists of strapping or bolting. Tieing or wiring are prohibited.

VIII. SPECIAL TOOLS

Tools shall be packed in an individual, steel strapped, rugged, wood box and marked as "special tools". However, large pieces, such as disassembly cradles, may be packed the same as the main equipment.

IX. SPARE AND REPLACEMENI PARTS

A. Small spare and replacement parts shall be packed in an individual, steel-strapped, rugged wood box for rail or truck shipment. A steel-strapped,sturdy, well packed carton is permissible for parcel post and air freight shipment.

B. Large spare and replacement parts, such as rotor assemblies, are to be prepared and enclosed the same as the main machinery unless otherwise directed by the purchase order or requisition.

X. CRMENT AND RETRACIIURY MATERTALS

These materials shall not be shipped to the construction site more than 6 months prior to use. High alumina refractories rapidly deteriorate particularly in a hot climate and special shipping scheduling shall be made for this material. 
ENG STD $27 A 1$

PAGE 10

FOSTER

REVISION

DATE Feoruary 1.1979.
FOR SHTPMENT
PROCESS PLANTS DIVISION

XI . LONG TERM STORAGE

Material to be prepared for long term storage is beyond the scope of this soecification. Such requirements will be handled on an individuai basis.

XII. INSTALLATION INSTRUCTIONS AND DRAWINCS

One set of installation instructions and drawings shall be included with the shipment in a sealed waterproof envelop iimly attached directly to the equipment within the packing contairer.

XIII. MARKINGS, COMQAERCIAI DOCURENTS

A. The shipoer shall stencil on the outside of the shipping case appropriate instructions for the handling, transport, and storage of equipment.

B. Other marking of shipment, supply of packing lists, invoices, et. shall be as specified on the purchase order. 
- TABLE A -

GUIDE TO CHOICE OF SHIPPING ENCLOSURE

\begin{tabular}{|c|c|c|c|c|c|c|c|c|}
\hline & & & & & & & & Date February 1, 1979 \\
\hline CLASS OF MATERIAL & $\begin{array}{l}\text { NAILED } \\
\text { WOODEN } \\
\text { BOX }\end{array}$ & $\begin{array}{l}\text { FIBR'E } \\
\text { BOX }\end{array}$ & $\begin{array}{l}\text { FIBRE } \\
\text { DRUM }\end{array}$ & $\begin{array}{l}\text { NETAL } \\
\text { DRUM }\end{array}$ & SKIDDED & $\begin{array}{l}\text { PLYWCOD } \\
\text { DRUM }\end{array}$ & $\begin{array}{l}\text { TEXTILE } \\
\text { BAGS }\end{array}$ & $\begin{array}{ll}\text { MULTI-WALL } & \text { BUIDLE ICOS } \\
\text { SHIPPING } & \text { or COIL } \\
\text { SACKS } & \end{array}$ \\
\hline
\end{tabular}

1. Strustural Parts

2. Major Items metal or wcod

a. Large Machinery

b. Medium-Small Machinery

3. Tools \& Machine Farts

4. Pipe

$$
\text { a. 3" and above }
$$

b. 2" and below

5. Metal rods \& sheets

6. Bulk Materials - Solids

7. Loose articles not subject to darlage in transit

8. Hardware \& Fittings

9. Hire \& Cable

10. Furniture-Office \& Field

11. Instruments

.12. Iriquids - in bulk

13. Iicuids - in containers

14. Chemicals - in bcitles

15. Chemicals - Inert.

Granular - in bulk

16. Cremicals, Inert,

Grenilar - in cortainer

17. E...ssure Vessels

c.: 3 i Diameter and above

b. 3' Dianeter and below

18. Heat Exchangers

19. Spare Parts

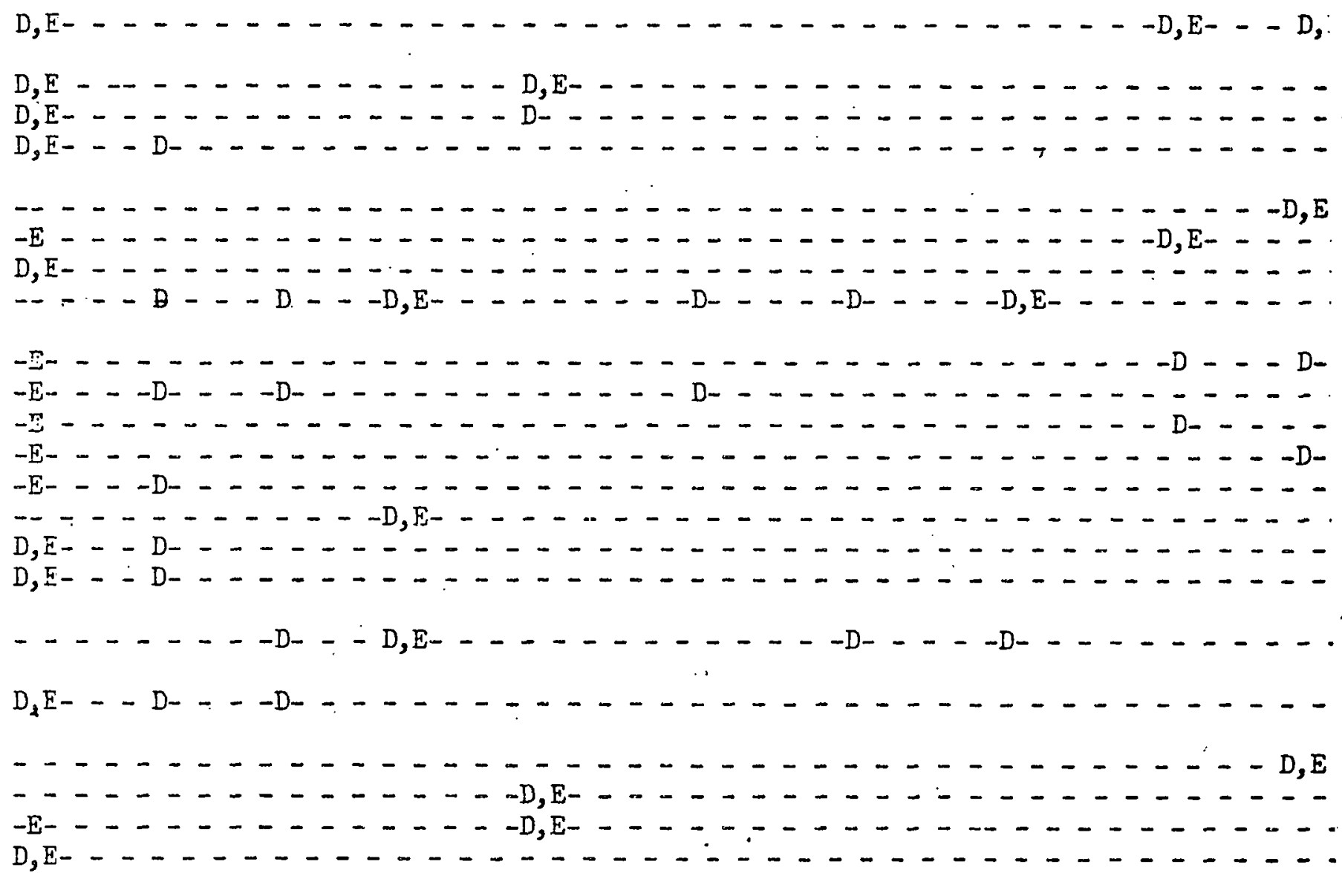

\section{NOTES:}

1. "D" designates acceptable for domestic shipment.

2. " $E$ " designates suitable for export shipment.

3. See I.C.C. regulations for chemicals and other dangerous substances. 
FOSTER THATERT WHER

PROCESS PLANTS DIVISION
EXTENT OF INSPECTION TO BE

PERFORMED AT VENDORS' PLANTS

JOB SPECIFICATION 60863-98AI

INDEX
ENG STD $98 \mathrm{~A}$

PAGE A

REVISION 1

DATE Feb. 1, 1979

I. SCOPE

PAGE NO.

II. EXTENT OF INSPECTION OF VESSELS - SECTION 1100

A. Towers, Reactors, Regenerators, Tanks, Drums and Deaerators

B. Tower Internals

C. USA Field Erected Spheres \& API Stor. Tanks (Erect. by Vendor)

D. Overseas Field Erected Spheres \& API Stor. Tanks (Erect. by Others)

E. Miscellaneous Vessels

III. EXTENT OF INSPECTION OF HEAT TRANSFER EQUIPT. - SECTION 1200

A. Shell and Tube Exchangers 3

B. Air Cooled Exchangers 3

C. Fired Process Heaters . 3

D. Vacuum Equipment, Including Condensers 4

E. Other Heat Exchange Equipment 4

IV. EXTENT OF INSPECTION OF MECHANICAL EQUIPMENT - SECTION 1300

A. Pumps 4

B. Compressors 5

C. Pump and Compressor Drivers 5

D. Mixers and Agitators 5

E. Material Handling, Finishing and Packaging Equipt. 5

F. Rotary Filters 5

G. Pulsation Dampers 5

H. Double Pipe Exchangers (Scraped Surface) 5

J. Refrigeration Systems - Package (Except Air Conditioners) 6

V. EXTENT OF INSPECTION FOR CIVIL ENGINEERING - SECTION $1400 \quad 6$

VI. EXTENT OF INSPECTION FOR PIPING MATERIALS - SECTION $1500 \quad 6$

A. Valves 6

B. Shop Fabricated Piping 7

C. Random Pipe

D. Fittings 8

E. Hlanges 8

F. Bolts, Studs \& Gaskets . . 8

G. Underground 8

H. Piping Specialties 8 
FOSTER WHEELER

PROCESS PLANTS DIYISION
EXTENT OF INSPECTION TO BE

PERFORMED AT VENDORS' PLANTS

JOB SPECIFICATION 60863-98AI

INDEX
ENG STD $98 \mathrm{~A}$

PAGE B

REVISION 1

DATE Feb. 1, 1979

VII. EXTENT OF INSPECTION FOR INSTRUMENTS - SECTION 1600

PAGE NÓ.

$\begin{array}{lr}\text { A. Instruments, Control Valves and Safety Valves } & 8 \\ \text { B. Analyzers } & 9 \\ \text { C. Control. Panels } & 9 \\ \text { D. Instrument Piping } & 9 \\ \text { E. Instrument Electric } & 9 \\ \text { F. Weather Protection } & 9 \\ \text { G. Supports and Racks } & 9\end{array}$

VIII. EXTENT OF INSPECTION FOR ELECTRICAL - SECTION 1700 - 9

A. Underground Electrical 9

B. Power Equipment 9

C. Power Distribution 9

D. Lighting 9

E. Communications 10

F. Support and Racks 10

IX. EXTENT OF INSPECTION FOR MATERIALS PROTECTION - SECTION 180010

X. EXTENT OF INSPECTION FOR PROJECT AND MISCELLANEOUS ITEMS - 10 SECTION 1900

$\begin{array}{ll}\text { A. Process Driers } & 10 \\ \text { B. Steam Generators and Boilers } & 10 \\ \text { C. Cooling Towers } & 11 \\ \text { D. Miscellaneous Items } & 11\end{array}$ 
FOSTER WHEELER

PROCESS PLANTS DIVISION
EXTENT OF INSPECTION TO BE

PERFORMED AT VENDORS' FLANTS
ENG STD $98 \mathrm{~A} 1$

PAGE 1

REVISION 3

DATE Feb. 1, 1979

I. SCOPE

A. This standard shall govern the extent of inspection of all purchased equipment and materials to be performed by Foster wheeler at vendors' plants.

B. The following inspection percentages are related to the quantity of the items of equipment and materials on a given project and are not intended to indicate the degree of inspection to be performed.

1. Where $100 \%$ inspection is specified, each item will be inspected.

2. Where $10 z$ inspection is specified, only 108 of the total quantity purchased on each order will be inspected.

c. In the event of a conflict between quality standards and delivery schedules, the Chief Inspector's decision shall govern.

D. Customer notification for inspection shall be for final inspection only and limited to only those items that are specifically intended to be inspected by the customer, the list of which is to be included in the contract coordination procedure.

E. Typewritten Foster wheelex equipment/material inspection reports will be transmitted to the customer on a regular basis as inspection visits are made.

II. EXTENT OF INSPECTION OF VESSELS-SECTION 1100

A. Towers, Reactors, Regenerators, Tanks, Drums and Deaerators

100 inspection which will consist of the following:

1. Identify all materials against material test certificates, including verification of plate thicknesses to assure all conform to purchase order requirements.

2. Review all radiographs.

3. Witness crack detection, hardness checks, ultrasonic tests, etc. which may be specified. If unable to witness these tests, a shop certification of satisfactory completion shall be obtained for inspection records. If any doubt exists as to the validity of the certification, spot checks will. be requested.

4. Witness hydrostatic tests jointly with the code inspector. 


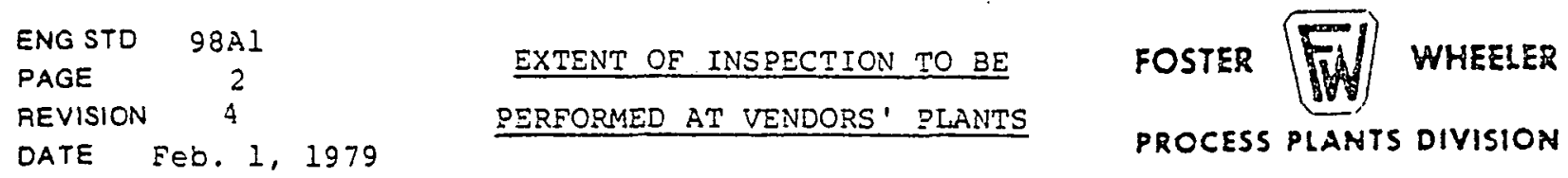

II. EXTENT OE INSPECTION OF VESSELS-SECTION 1100 (Cont' $d$ )

A. Towers, Reactors, Regenerators, Tanks, Drums and Deaerators (Cont'd)

5. Dimensionally check for accuracy and visually inspect for cleanliness and quality of workmanship.

6. Check for completeness of installation of internal and external attachments, except for the installation of trays which will be inspected at the joosite during or after installation into their respective towers.

\section{B. Tower Internals}

1. Except Ior prototypes or new vendors, no inspection of internals will be required at vendor's plant. Internals, except trays, shall be inspected during or after installation into their respective towers. Installation of trays will be inspected at the job site.

2. For prototypes or new vendors, inspection of trays, wili be recuired winch will consist of the following:

a. Identify all materials against material test certificates incluaing verification of plate thicknesses to assure all conform to purchase order requirements.

b. Witness leakage tests.

c. Dimensionally check for accuracy and visually inspect for guality of workmahship of $25 \%$ of each type and size.

d. Spot check (203 maximum) for interchangeability of parts.

C. USA Field Erected Spheres and API Storage Tanks (Erected by Vendor)

No inspection will be required.

D. Overseas Field Erected Soheres and API Storage Tanks (Erected by Others)

100s inspection wich will consist of the following:

1. Identify all materials against material test certificates, incluoing verification of plate thicknesses to assure all conform to purchase order recuirements.

2. Dimensionally check all shell plate after forming.

3. Visually inspect all welding. 


\begin{tabular}{llll} 
FOSTER WHEELER & \multicolumn{2}{c}{ ENG STD } & $98 A 1$ \\
PROCESS PLANTS DIVISION & EXTENT OF INSPECTION TO BE & $\begin{array}{l}\text { PAGE } \\
3\end{array}$ \\
PERFORMED AT VENDORS' PLANTS & REVISION & 3 \\
DATE FEb. 1,1979
\end{tabular}

II. EXTENT OF INSPECTION OF VESSELS-SECTION 1100 (Cont'd)

D. Overseas Field Erected Spheres and API Storage Tanks (Erected by Others (Cont'd)

4. If radiographs are required for sub-assemblies, they shall be reviewed.

5. Obtain chart or diagram showing field fabrication sequence or arrangement, complete with all plate numbers. This will be forwarded to the foreign office originating the purchase.

E. Miscellaneous Vessels

Inspection will be as specified in the item requisition.

III. EXTENT OF INSPECTION OF HEAT TRANSFER EQUIPT. -SECTION 1200

A. Shell and Tube Exchangers

1008 inspection which will consist of the following:

1. Same as II A above, including complete inspection of the tube side.

2. For stacked exchangers, a final dimensional inspection will be performed in the shop on the complete assembly.

B. Air Cooled Exchangers

100 inspection which will consist of the following:

1. Same as II A above for the fabrication of headers and tube bundles.

2. A shop certification of satisfactory fan blade balance will be obtained for inspection records.

3. Check motor driver unit against its requisition.

4. Spot check all structural steel for dimensional accuracy and visually inspect for quality of workmanship.

c. Fired Process Heaters

1008 inspection which will consist of the following:

1. Identify all materials against mill test certificates to assure all conform to Purchase order requirements.

2. Mill inspection shall be made for all alloy tubes of 58 or greater chrome content. 
$\begin{array}{lc}\text { ENG STD } & 98 A I \\ \text { PAGE } & 4 \\ \text { REVISION } & 3\end{array}$

DATE FEb. 1,1979
EXTENT OF INSPECTION TO BE

PERFORMED AT VENDORS' PLANTS
FOSTER WHEEIER

PROCESS PLANTS DIVISION

III. EXTENT OE INSPECTION OF HEAT TRANSFER EQUIPT.-SECTION 1200 (CONT'd)

C. Fired Process Heaters (Cont'd)

3. Review all radiograpins.

4. Witness crack detection, hardness checks, ultrasonic tests, etc. which may be specified. If unable to witness these tests, a shop certification of satisfactory completion will be obtained for inspection recoras. If any coubt exists as to the validity of the certification, spot checks will be requested.

5. Witness hydrostatic tests jointly with the code inspector. For packaged unit, hydrostatic tests and final inspection will be made in the shop on the complete assembly.

6. Dimensionally check for accuracy and visually inspect for cleanliness and quality of workmanship.

7. Inspect installation of anchors and refractory lining.

8. Spot check all structural steel, ducting and stacks for dimensional accuracy and visually inspect for quality workmanship.

D. Vacuum Equipment, Including Condensers

loog inspection which will consist of the following:

1. As far as applicable, inspection of condensers will be the same as for shell and tube exchangers. See III. A.

2. Inspection of ejectors will consist of witnessing performance or other shop tests together with a dimensional and visual inspection.

E. Other Heat Exchange Equioment

Inspection will be as specified in the item requisition.

IV. EXTENT OF INSPECTION OE MECHANICAL EQUIPMENT-SECTION 1300

A. Puinos

Inspection of pumps will normally be conducted only for pumps in excess

of $500 \mathrm{HP}$, special applications, prototype units and new vendors. 
FOSTER WHEELER

PROCESS PLANTS DIVISION
EXTENT OF INSPECTION TO BE

PERFORMED AT VENDORS' PLANTS
ENG STO $98 \mathrm{AI}$

PAGE

REVISION 4

DATE Feb. 1, 1979

IV. EXTENT OF INSPECTION OF MECHANICAL EQUIPMENT - SECTION 1300 (Cont'd)

B. Compressors

Except for standard plant and instrument air compressors and small standard blowers, all compressors will be inspected, including their lubrication, sealing and cooling systems.

C. Pump and Compressor Drivers

1. Motors in excess of $500 \mathrm{HP}$ will be inspected.

2. Steam turbines in excess of $500 \mathrm{HP}$, multistage turbines and turbines in excess of 5000 RPM will be inspected.

D. Mixers and Agitators

Inspection of agitators and mixers will be conducted only for special applications, prototype units and new vendors.

E. Materials Handling, Finishing and Packaging Equipment

Except for standard equipment manufactured on a stock basis, all units will be inspected.

\section{F. Rotary Filters}

All rotary and vacuum filters will be inspected.

G. Pulsation Dampers

1008 inspection which will consist of the following:

Same as for II A above, with special consideration given to internal cleanliness.

H. Double Pipe Exchangers (Scraped Surfaces)

$100 \frac{9}{3}$ inspection which will consist of the following:

1. Same as II. A above, including all piping and internals.

2. Check motor driver against its requisition.

3. Witness shop running test and perform a final dimensional inspection on the complete assembly. 


\begin{tabular}{|c|c|c|c|c|c|}
\hline $\begin{array}{l}\text { ENG STO } \\
\text { PAGE }\end{array}$ & $98 \mathrm{Al}$ & EXTENT OF INSPECTION TO BE & FOSTER & 51 & WHEELER \\
\hline REVISION & 4 & PERFORMED AT VENDORS' PLANTS & & & \\
\hline DATE & . 1,1979 & & PRO & ANTS & DIVISION \\
\hline
\end{tabular}

\section{EXTENT OF INSPECTION OE MECHANICAL EQUIPMENT-SECTION 1300 (Cont'd)}

\section{J. Refrigeration Systems-Package (except Air Conditioners)}

1. Inspection will be as specified in the item requisition.

2. No inspection will be required for package type air conditioners.

\section{ivotes on Inspection}

1. The requisition data sheet and/or referenced specification will indicate the extent of shop testing to be performed by the mànufacturer and which tests will be witnessed.

1. Inspection will be conducted during assembly and/or prior to preparation for shipment and will consist of:
a) Check for compliance to the requirements of the Purchase Order.
b) Check for completeness of vendor's work and/or availability of all component parts and accessory items.
c) Visually inspect for cleanliness and quality of workmanship.
d) Complete dimensional check to assure its conformity to vendor's certified outline drawings.
e) Witness those tests specified to be witnessed as indicated on the requisition data sheet and/or referenced specification.

V. EXTENT OF INSPECTION OF CIVIL ENGINEERING-SECTION 1400

In general, no inspection will be required.

VI. EXTENT OF INSPECTION OF PIDING MATERIALS-SECTION 1500

\section{A. Valves}

1. 100 inspection will be required for motor operated valves, slide valves, switch values, butterfly valves $14 "$ and larger and any other valve as may be specified in the item requisition. Inspection will consist of the following:
a. Identify material against material test certificates to assure all conform to purchase order requirements.
b. Witness crack detection, hardness checks, Charpy tests, etc., which may be specified. If unable to witness these tests, a shop certification of satisfactory completion will be obtained for inspection records. If any doubt exists as to the validity of the certification, spot checks will be requested.
c. iitness hycirostatic tests of body and seat. 


\section{FOSTER \\ Fif WHEELR}

PROCESS PLANTS DIYISION
EXTENT OF INSPECTION TO BE

PERFORMED AT VENDORS ' PLANTS
ENG STO

PAGE

REVISION 5

DATE Feb. 1,1979

VI. EXTENT OF INSPECTION OF PIPING MATERIALS-SECTION 1500 (Cont'd)

A. Valves (Cont'd)

1. (Cont'd)

d. Dimensionally and visually inspect to ensure conformity to standards and specifications.

e. Ensure valve is properly metal-tagged with item number as indicated in requisition.

f. For motor operated valves, visually inspect motor for conformity to requisition.

2. All other valves will not require inspection.

3. No inspection will be reguired for valve accessories such as chain wheels, guides, extension stems, floor stands, etc.

\section{B. Shop Fabricated Piping}

Unless otherwise indicated on piping drawings or specified in the item requisition:

1. The type and extent of required examination will be in accordance with ENG STD 50Al Paragraph VIII., including a review of all radiographs.

2. No additional inspection will be required for carbon steel piping 12" size and smaller. For all carbon steel piping $14 "$ size and larger and for all sizes of alloy steel and non-ferrous piping, a spot check (average. 108) inspection will be required consisting of the following:

a. Identify all material against mill test certificates to assure all conform to purchase order requirements.

b. Check to ensure that welding procedures used agree with those approved by Foster Wheeler Energy Corporation Engineering Department.

c. Witness hydrostatic test, if required.

d. Review stress relieving procedures and check Brinell hardness.

e. Dimensionally inspect for accuracy and visually inspect for guality of workmanship. Closely inspect the interior for cleanliness, especially the welds.

3. All sizes of compressor suction and interstage piping will be closely inspected for interior cleanliness. If special cleaning is required it will be defined in the requisition. 


$\begin{array}{lccc}\text { ENG STD } & 98 A 1 & & \text { FOSTER } \\ \text { PAGE } & 8 & \text { EXTENT OF INSPECTION TO BE } & \text { WHEELER } \\ \text { REVISION } & 4 & & \text { PEREORMED AT VENDORS' PLANTS } \\ \text { DATE FED. } 1,1979 & \text { PROCESS PLANTS DIVISION }\end{array}$

VI. EXTENT OF INSPECTION OF PIPING MATERIALS-SECTION 1500 (COnt'd)

C. Random Pipe

No inspection will be required.

D. Fittings

Inspection will be required for special (non-standard) cast alloy steel and carbon steel fittings only and will be specified in the item requisition. When inspection is required, it will consist of the following:

1. Identify material against material test certificates to assure all conform to purchase order requirements.

2. Witness hydrostatic test of cast fittings only.

3. Witness crack detection, hardness checks, etc. which may be speciEied.

4. Dimensionally and visually inspect to ensure fittings conform to drawings and specifications.

E. Elanges

No inspection will be required.

F. Bolts, studs \& Gaskets

No inspection will be required.

G. Underaround

No inspection will be required.

H. Piping specialties

No inspection will be required.

VII. EXTENT OF INSPECTION OE INSTRUMENT-SECTION 1600

A. Instruments, control valves and safety valves

Generally, these items in not reguire inspection. In special cases, inspection may be required. Consideration will be based on such factors as: prototype units, new vencors, units for export, critical nature of use. 


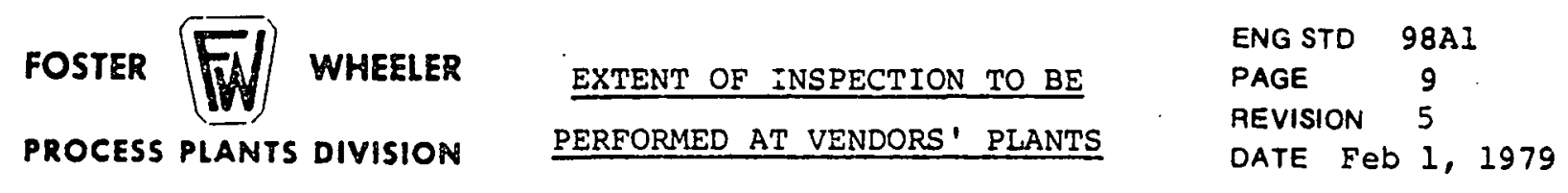

VII. EXTENT OF INSPECTION OF INSTRUMENTS-SECTION 1600 (Cont'd)

B. Analyzers

Inspection of analyzers will normally apply to prototype units, new vendors, units for export and special applications.

c. Control Panel

Normally, control panels will be inspected. The extent and nature of inspection will be defined by the Instrument Engineering Section.

D. Instrument Piping

No inspection will be required.

E. Instrument Electrical

No inspection will be required.

F. Weather Protection

No inspection will be required.

G. Supports and Racks

No inspection will be required.

VIII. EXTENT OF INSPECTION FOR ELECTRICAL-SECTION 1700

A. Underground Electrical

No inspection will be required.

R. Pnwer Equipment

Generally, power equipment will not require inspection unless specified in the item requisition. When inspection is required, the extent and nature of inspection will be defined by the Electrical Engineering Section.

C. Power Distribution

No inspection will be requirrd.

D. Lighting

No inspection will be required. 


$\begin{array}{lccc}\text { ENG STD } & 98 A 1 & \text { EXTENI OF INSPECTION TO BE } & \text { FOSTER } \\ \text { PAGE } & 10 & \text { PERFORMED AT VENDORS' PLANTS } & \text { WHEELER } \\ \text { REVISION } & 5 & \text { PROCESS PIANTS DIVISION } \\ \text { DATE } & \text { FEb. } 1,1979 & \end{array}$

VIII. EXTENT OF INSPECTION FOR ELECTRICAL-SECTION 1700 (Cont'd)

E. Communications

No inspection will be required.

F. Supports and Racks

No inspection will be required.

IX. EXTENT' OF INSPECTION FOR MATERIALS PROTECTION-SECTION 1800

No inspection will bo required.

X: EXTENT OF INSPECTION EOR PROJECT \& MISCELLANEOUS ITEMS-SECTION 1900

A. Process Driers

100 inspection which will consist of the following:

1. Same as II. A disove.

2. Witness vendor's standard shop tests and those as may be specified in the item requisition.

B. Steam Generators and Boilers

$100 \%$ inspection which will consist of the following:

1. Inspection of all drums and headers will be as specified in II. A above:

2. Identify all carbon steel and low alloy tube material against mill test certificates to assure all conform to purchase order requirements.

3. Mill inspection shall be made for all alloy tubes of $5 \%$ or greater chrome content.

4. Witness crack detection, haroness checks, ultrasonic test, etc., which may be specified. If unable to witness these tests, a shop certification of satisfactory completion will be obtained for inspection records. If any doubt exists as to the validity of the certification, spot checke will be requested.

5. Dimensionaliy check for accuracy anc visually inspect for cleanliness and quality of workmanship. 
FOSTER WHEELER

PROCESS PLANTS DIVISION
EXTENT OF INSPECTION TO BE

PERFORMED AT VENDORS' PLANTS
ENG STD $98 A 1$

PAGE 11

REVISION 3

DATE Feb. 1, 1979

X. EXTENT OE INSPECTION FOR PROJECT \& MISCELLANEOUS ITEMS-SECTION 1900 (Cont'd)

B. Steam Generators and Boilers (Cont'd)

6. Spot check all structural steel, ducting and stacks for dimensional accuracy and visually inspect for quality of workmanship.

7. Witness hydrostatic tests jointly with the code Inspector. For packaged units, hydrostatic tests and final inspection will be made in the shop on the complete assembly.

8. Inspect installation of anchors and refractory lining.

c. cooling Towers

1008 inspection of fan unit only which will consist of the following:

1. A shop certification of satisfactory fan blade balance will be obtained for inspection records.

2. Witness standard shop test or running test as specified in the requisition for the item.

3. Check motor driver unit against its requisition.

D. Other Miscellaneous Items

Inspection will be as specified in the item requisition. 


\section{APPENDIX E}

FOUNDATION DESIGN 
FOSTER WHEELER DEVELOPMENT CORPORATION

JOHN BLIZARD RESEARCH CENTER

12 PEACH TREE HILL ROAD,

LIVINGSTON, NEW JERSEY 07039

BY .. ....GIG. DATE $4 / 25 / .7 .9$ SUBJECT FOUNDATION A DESIGN SHEET NO. OF...6

CHKD. BY DATE FOR HEXCEL/.SUMTEC COLLECTOR

JOB NO

$9-41-4010$

FOUNDATION DESIGN

FROM ANSI 58.1, DESIGN WIND LOAD FOR ATLANTA, GEORGIA SHOULD USE A WIND SPEED OF $80 \mathrm{MPH}$. ASSUME THE SAME WIND SPEED FOR DALTON, GEORGIA.

WIND LOADS ACTING ON THE FOUNDATIONS FOR VARIOUS COLLECTOR ORIENTATIONS ARE SHOW M IN FIGURE 4.1. REFERENCE (15) WAS USED FOR THIS FOUNDATION DESIGN. CYLINDRICAL CONCRETE PILES WERE SELECTED BECAUSE OF THEIR LOW INSTALLATION COSTS.

FOR THE WIND LOADS FOR OPERATION COLLECTOR ORIENTATIONS, FACTOR OF SAFETY USED IS ONE. THE MAXIMUM A WIND LOADS DURING OPERATION MAY OCCUR AT $\theta=0^{\circ}$. THESE LOADS ARE:

$$
\begin{aligned}
\text { VERTICALLY UPWARD } & =2950 \mathrm{LB} . \\
\text { VERTICALLY DOWNWARD } & =2950 \mathrm{LB} . \\
\text { LATERAL } & =1560 \mathrm{LB} . \\
\text { DEAD LOAD, DOWNWARD } & =372 \mathrm{LB} .
\end{aligned}
$$

FER THE WIND LOADS IN STOWED POSITION, FACTOR OF SAFETY USED IS THREE. THE WIND LOADS UNDER THIS CONDITION ARE SHOWN IN FIGURE 4-1, FOR $\theta=-90^{\circ}$ AS:

$$
\begin{array}{ll}
\text { VERTICALLY UPWARD } & =-164 \text { LB. } \\
\text { LATERAL } & =520 \mathrm{LB} .
\end{array}
$$

FORM D-22 
BY .......GDG .........DATE.4/25/.79.. SUBJECT FOUNDATION .DESIGN

CHKD. BY DATE. SHEET NO. ..................6 JOB NO. $9-41-4010$

\section{DESIGN CONFIGURATION}

THE SELECTED CYLINDRICAL PILE IS 16 INCHES IN DIAMETER AND 4 FEET 9 INCHES DEEP. 4 FEET OF THE PILE IS UNDERGROUND. THE FOUNDATION DESIGN IN THIS CASE IS GOVERNED BY THE VERTICALLY UPWARD AND LATERAL LOADS.

$Q_{V}=$ VERTICALLY UPWARD LOAD QH = LATERAL LOAD

FROM REFERENCE (15), THE CONCRETE PILE SHOULD SATISFY

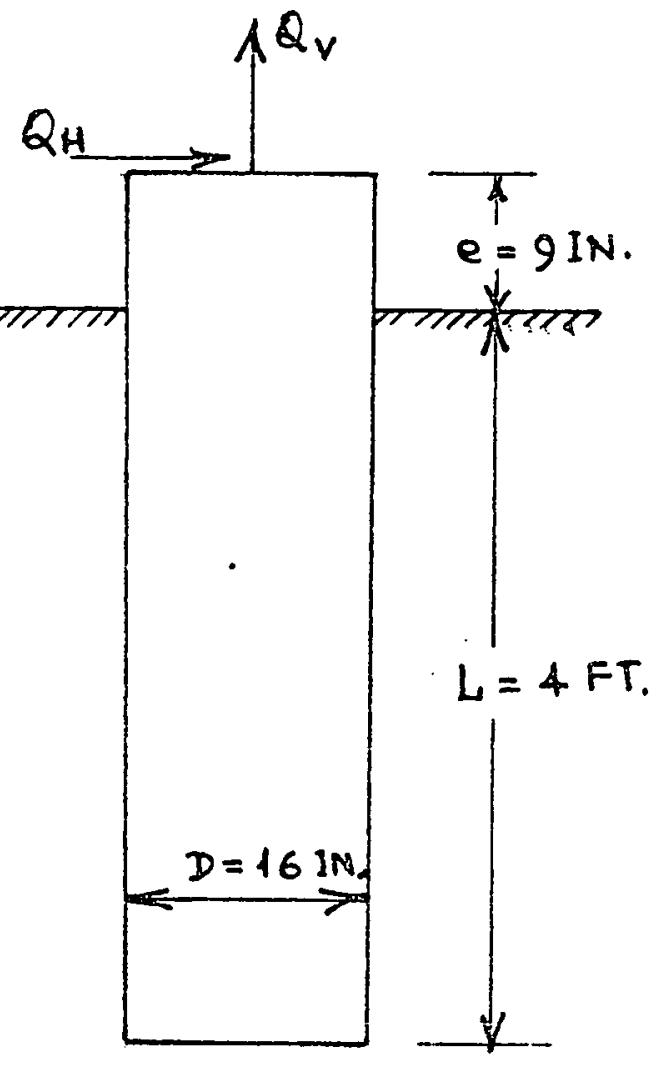
THE FOLLOWING EQUATION-

$$
\frac{Q_{V}}{Q_{U V}}+\left(\frac{Q_{H}}{Q_{U M}}\right)^{2} \leq 1
$$

WHERE

QUV = GROSS ULTIMATE RESISTANCE FOR VERTICAL LOAD ALONE QUM = GROSS ULTIMATE RESISTANCE FOR LATERAL LOAD ALONE 
FOSTER WHEELER DEVELOPMENT CORPORATION

JOHN BLIZARD RESEARCH CENTER 12 PEACH TREE HILL ROAD,

LIVINGSTON, NEW JERSEY 07039

BY GD DATE A/25/.7.9. SUBJECT FOUNDATION DESIGN SHEET NO..... 3

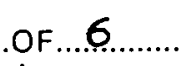

CHKD. BY .DATE. JOB NO ................10

II calculation of Qu

FROM REFERENCE (15),

$$
\text { Qu }=r \cdot A_{s}+W
$$

WHERE

$r=$ AVERAGE UNIT RESISTANCE TO UPLIFT

$A_{S}=$ EMBEDDED SURFACE. AREA

$$
=\pi D L=\pi \times \frac{16}{12} \times 4=16.75 \mathrm{FT}^{2}
$$

$W=W T$. OF THE CONCRETE PILE INCLUDING DEAD WEIGHT ACTING ON IT.

$$
\begin{aligned}
& =\frac{X D^{2}}{4}(L+e) P_{C}+\text { DEAD LOAD } \\
& =\frac{\pi}{4}\left(\frac{16}{12}\right)^{2} \times 4.75 \times 150+372 \\
& =995+372=1367 \text { LB. }
\end{aligned}
$$

$$
\begin{aligned}
P_{C} & =\text { DENSITY OF CONCRETE } \\
& =150 \mathrm{LB} / \mathrm{FT}^{3} \\
\dot{r} & =k_{C} C_{U}+\frac{1}{2} k_{U} \bar{r} L \tan \delta
\end{aligned}
$$

$$
\begin{aligned}
\text { WHERE } & \\
K_{C}, K_{U} & =\text { UPLIFT COEFFICIENTS } \\
C_{U} & =\text { COHESIVE STRENGTH } \\
& =1 / 2 \text { UNCONFINED COMPRESSIVE STRENGTH } \\
\bar{\gamma} & =\text { EFFECTIVE UNIT WT. OF SOIL } \\
\delta & =\text { SKIN FRICTION. PARAMETER } \\
& =0.6 \phi
\end{aligned}
$$

FORM D.22 
FOSTER WHEELER DEVELOPMENT CORPORATION

BY .............. DATE $4 / 25 / 79 \ldots$ SUBJECT FOUNDATION DESIGN

CHKD. BY
JOHN BLIZARD RESEARCH CENTER

12 PEACH TREE HILL ROAD,

LIVINGSTON, NEW JERSEY 07039

SHEET NO.... 4

.O F...6.

JOB NO: $9-41-4010$

$\phi=$ ANGLE OF INTERNAL FRICTION

FROM REF. ( 15),

$k_{c}=0.5$

$k_{u}=2 \cdot 0$

ASSUMING $\phi=20$ DEG.

$\delta=12$ DEG.

$\tan \delta=0.213$

AsSUME $\quad \frac{\delta}{\gamma}=100 \mathrm{LB} / \mathrm{Fr}^{3}$

$$
\begin{aligned}
& \text { FROM REF. (16), } \\
& \qquad C_{U}=1500 \mathrm{LB} / \mathrm{FT}^{2}
\end{aligned}
$$

THEREFORE,

$$
\begin{aligned}
k & =0.5 \times 1500+\frac{1}{2} \times 2 \times 100 \times 4 \times 0.213 \\
& =750+85.2 \\
& =835.2 \mathrm{LB} / \mathrm{FT}^{2} \\
\therefore \quad Q_{U V} & =835.2 \times 16.75+1367 \\
& =15357 \mathrm{LB}
\end{aligned}
$$

ie. FOR THE VERICALLY UPWARD LOAD ALONE, THE FOUNDATION CAN TAKE 15357 LBS.

FORM D-22 
FOSTER WHEELER DEVELOPMENT CORPORATION

BY ..........P.

CHKD. BY DATE. $4 / 25 / \%$ I. . SUBJECT FOUNDATION DE DESIGN DATE

JOHN BLIZARD RESEARCH CENTER

12 PEACH TREE HILL ROAD.

LIVINGSTON, NEW JERSEY 07039

SHEET NO. ... $5 \ldots \ldots \ldots \ldots$.............

JOB NO. $9-41-4010$

III CALCULATION OF QUM

FROM REF. (15),

$$
Q_{U M}=\frac{0.5 \bar{V} D L^{3} K p}{e+L}
$$

WHERE $K_{P}=$ COEFFICIENT OF PASSIVE EARTH PRESSURE

$$
\begin{aligned}
& =\frac{1+\sin \phi}{1-\sin \phi} \\
& =\frac{1+0.342}{1-0.342}
\end{aligned}
$$

$$
=2 \cdot 04
$$

$$
\begin{aligned}
\text { QUM } & =0.5 \times 100 \times \frac{16}{12} \times(4)^{3} \times\left(\frac{2.04}{4.75}\right) \\
& =1832 \mathrm{LB} .
\end{aligned}
$$

ie. FOR tHE LATERAL LOAD ALONE, THE FOUNDATION CAN TAKE 1832 LBS.

IV ACCURACY OF DESIGN

a. IN-OPERATION LOAD

$$
\begin{aligned}
& Q_{V}=2950 \text { LB. } \\
& Q_{H}=1560 \text { LB. }
\end{aligned}
$$

FORM D-22 
FOSTER WHEELER DEVELOPMENT CORPORATION

$B Y \ldots$ GD.........

CHKD. BY DATE. $4 / 25 / 79 \ldots$ SUBJECT FOUNDATION DESIGN DATE.

$$
\begin{aligned}
\therefore \quad \frac{2950}{15357}+\left(\frac{1560}{1832}\right)^{2} & =0.192+0.725 \\
& =0.92
\end{aligned}
$$

HENCE THE FOUNDATION SATISFIES THE IN-OPERATION LOAD REQUIREMENTS

JOHN BLIZARD RESEARCH CENTER 12 PEACH TREE HILL ROAD.

LIVINGSTON, NEW JERSEY 07039

b. STOWED LOADS

$$
\begin{aligned}
& Q_{V}=492 \mathrm{LB} . \\
& Q_{H}=1560 \mathrm{LB} .
\end{aligned}
$$

$$
\begin{aligned}
\therefore \quad \frac{492}{15357}+\left(\frac{1560}{1832}\right)^{2} & =0.032+0.725 \\
& =0.757
\end{aligned}
$$

HENCE THE FOUNDATION HAS A FACTOR OF SAFETY OF 3 FER WIND LOAD IN STOWED POSITION

FORM D-22 


\section{APPENDIX. $F$ \\ FAILURE MODES AND \\ EFFECTS ANALYSIS SHEETS}




\author{
Appendix D
}

FAILURE MODE AND EFFECTS ANALYSIS

The failure modes and effects analysis of the solar stean generating plant is presented in this appendix. This analysis takes each subsystem and examines $i t$ by function, looking at each component or comporent set. The pos-sible modes of failure are examined to deterinine all? their possible causes, how they might be detected, and the effect of that failure--locally within the subsystem and ultimately on the operation of the plant. It delineates any existing features that compensate for that fajlure and makes: a qualitative assessmeni of both the severity of the specific failure mode and its probability of occurrence. Each failure mode is accompanied, when necessary, by remarks and/or recominenda-tions which set forth the assumptions made or further elucidate that mode analysis.

The criticality of a failure mode is based on the interaction of severity of effect and the probability of occurrence.* obviousiy, a failure mode which may have a severe effect and which has a high probability of occurrence should be examined closely. Steps can then be taken to assure that there are adequate provisions to compensate for that fajlure mode, that it can be deiected quickly, and that the possible causes can be el iminated wherever possible or reduced as much as practical. A failure mode which has a high probability of occurrerice but negligible effects, or one that is severe but has almost no chance of occurrence, can be given a lower degree of concern than one which is both moderately severe and has a moderate probability of occurrence.

The criteria used for assigning probability levels and levels of severity are shown below:

\title{
PROBABILITY
}

- Levei 1 - Failure mode probability very low. A negligible chance of occurrence during the item's lifetime.

- Level 2 - Failure mode probability low. Unilikely to occur during the item's lifetime.

*No criticality ranking is provided. The definition of criticality as the product of the severity and probability of a failure mode is misleading (P. E. Vanden Dries, "Rational Risk Assessment for Defence System Safety," Proceedings, Annual Reliability and Mäintainability Syrrposium, January 1979, IEEE, New York. 
- Level 3 - Failure mode probability medium. A random 50-50 chance of occurrence during the system's lifetime.

- Level 4 -Failure mode probability high. Frequent occurrence likely during the item's 1 ifetime.

\section{SEVERITY CLASSIFICATION}

- Level 1 - No effect on gasifier output. Negligible effect or degradation which can be repaired by performing "adjustment type" maintenance.

- Level 2 - Causes automatic shutdown with no consequent damage.

- Level 3 - Minor equipment failure or damage repairable by operators.

- Level 4 - Major equipment failure or damage not repairable by operators.

- Level 5 - Potential on-site fire or hazard to operators.

- Level 6 - Potential off-site fire or damage. 
Pallure Modes and Bal fertes Analystis

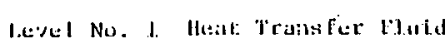

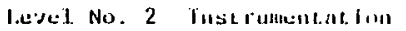

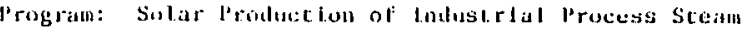

l.est No. 3

Mrawing: 60863-50-1

l.evel. No. 4

\begin{tabular}{|c|c|c|c|c|c|c|c|c|c|c|}
\hline \multirow{2}{*}{ 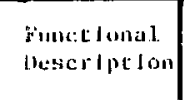 } & \multicolumn{2}{|c|}{ Pallure Mode } & \multirow{2}{*}{$\begin{array}{l}\text { Pousblile } \\
\text { Camses }\end{array}$} & \multirow{2}{*}{$\begin{array}{l}\text { Symptoms } \\
\text { Decectialsilifey }\end{array}$} & \multicolumn{2}{|c|}{ liffece of liallure } & \multirow{2}{*}{ 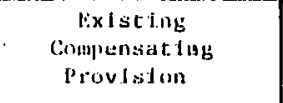 } & \multirow{2}{*}{$\begin{array}{l}\text { Irobat } \\
\text { bilicy }\end{array}$} & \multirow{2}{*}{$\begin{array}{l}\text { leved of } \\
\text { Severicy }\end{array}$} & \multirow{2}{*}{ Remarks } \\
\hline & $\mathrm{SN}$ & Descroptzon & & & local beftect & End liffect & & & & \\
\hline $\begin{array}{l}\text { Arciol actog } \\
\text { Putmp }(P-100 .)\end{array}$ & 1.10 & Stop: & $\begin{array}{l}\text { Power fill lure. } \\
\text { motor falliure. } \\
\text { deadlead ling }\end{array}$ & & $\begin{array}{l}\text { Circulation of } \\
\text { fluld stops: }\end{array}$ & 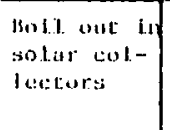 & $\begin{array}{l}\text { Solar collectors } \\
\text { stawed on decection } \\
\text { of low flow/piower } \\
\text { fatilure }\end{array}$ & 3 & $2 / 3$ & \\
\hline Blow Meter & 1.20 & $\begin{array}{l}\text { Folls lindicating } \\
\text { false low flow }\end{array}$ & Pal function & $\begin{array}{l}\text { No low flow ladi- } \\
\text { wated on wi-jul co } \\
\text { wo-11.5 }\end{array}$ & $\begin{array}{l}\text { Activation low } \\
\text { flow atatrin and } \\
\text { shintdown }\end{array}$ & $\begin{array}{l}\text { Spurious } \\
\text { shutduten }\end{array}$ & & 2 & 2 & \\
\hline - & 1.21 & $\begin{array}{l}\text { Wallis ludicat long } \\
\text { talse lid.gli f.low }\end{array}$ & Mal funce ton & & $\begin{array}{l}\text { Erroncous flows } \\
\text { recorilcal }\end{array}$ & $\begin{array}{l}\text { No low fin } \\
\text { shuestowis }\end{array}$ & $\begin{array}{l}\text { Stowilge of cotlec- } \\
\text { tors on electrical } \\
\text { failure ur overheat- } \\
\text { jug of eollectors }\end{array}$ & 2 & s & \\
\hline \multirow[t]{2}{*}{ 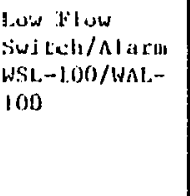 } & 1.22 & Fatils of & Malfunction & & $\begin{array}{l}\text { Rcdundancy in } \\
\text { low frlow a larms } \\
\text { loset }\end{array}$ & & $\begin{array}{l}\text { WSILL- }-100 / W A L L-1.00 \\
\text { and } W R-1.00\end{array}$ & 2 & 2 & \\
\hline & 1.23 & Falls on & $\begin{array}{l}\text { Sllort /ma I func- } \\
\text { Lionon }\end{array}$ & $\begin{array}{l}\text { Nolarm hut low flow } \\
\text { not ladtcated }\end{array}$ & $\begin{array}{l}\text { Possible manual } \\
\text { :iloutdown }\end{array}$ & & . & 2 & 1 & \\
\hline $\begin{array}{l}\text { Low-l.ow Flow } \\
\text { Swttel WSLL- } \\
1.00\end{array}$ & 1.24 & Watlis of $f$ & Malfunction & & 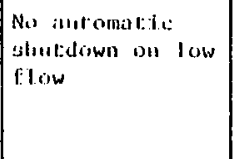 & & 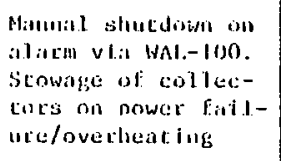 & 2 & 3 & 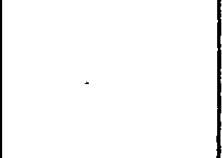 \\
\hline $\begin{array}{l}\text { Low-Low llow } \\
\text { Swit chl WSLLL- } \\
100\end{array}$ & 1.25 & Falls un & $\begin{array}{l}\text { Slicort/mat finc- } \\
\text { cton }\end{array}$ & & & 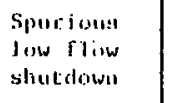 & & 2 & 2 & \\
\hline $\begin{array}{l}\text { l.sw-1.ow l.evel } \\
\text { Al.arill }\end{array}$ & 1.26 & Palls off & Mril funct: 1 ion & & $\begin{array}{l}\text { Ne allaten on low- } \\
\text { l.ow fllow }\end{array}$ & & WAL-100 and WR-100 & 2 & I. & \\
\hline Un1.i. -1.00 & 1.22 & Falls on & $\begin{array}{l}\text { phort/mal Lume- } \\
\text { plon }\end{array}$ & No shentdown accurs & Leew flow al atrin & & & 2 & 1 & \\
\hline RTu 'I"I-100) & 1.30 & $\begin{array}{l}\text { Pajls lindicat.ing } \\
\text { ralse hlgh tem- } \\
\text { perature }\end{array}$ & & 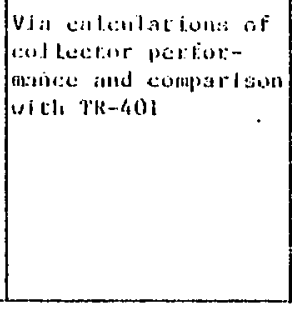 & 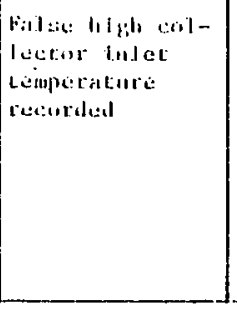 & 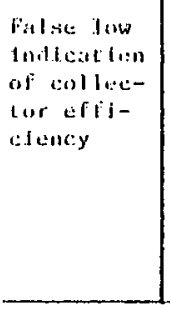 & & & & 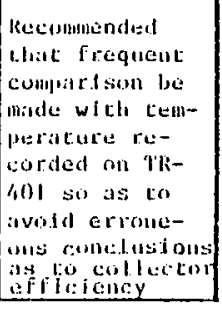 \\
\hline
\end{tabular}




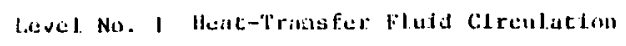
fevel No. 2 Instrunentatius, hines, col lector l.evel No. 3 Level No. 4
Prongratil: Solar I'roductilan of Industrlal Process Steam Deawing: $60863-50-1$.

\begin{tabular}{|c|c|c|c|c|c|c|c|c|c|c|}
\hline \multirow{2}{*}{$\begin{array}{l}\text { Functional } \\
\text { Description }\end{array}$} & \multicolumn{2}{|c|}{ Palluse Mode } & \multirow{2}{*}{$\begin{array}{l}\text { pozsible } \\
\text { Causcsi }\end{array}$} & \multirow{2}{*}{$\begin{array}{c}\text { Symptomis } \\
\text { Detectabliticy }\end{array}$} & \multicolumn{2}{|c|}{ Effect of fallure } & \multirow{2}{*}{$\begin{array}{l}\text { Pxisting } \\
\text { Compensitelug } \\
\text { Proviston }\end{array}$} & \multirow{2}{*}{$\begin{array}{l}\text { Prolia- } \\
\text { billicy }\end{array}$} & \multirow{2}{*}{$\begin{array}{l}\text { Level of } \\
\text { Severlity }\end{array}$} & \multirow{2}{*}{ Rematks } \\
\hline & $\mathrm{SN}$ & bescrlption & & & local Lefect & End Effect & & & & \\
\hline \multirow[t]{2}{*}{ KTI $4 T-401$} & 1.44 & $\begin{array}{l}\text { Falds luditeating } \\
\text { false hlgh tein- } \\
\text { peracure }\end{array}$ & & $\begin{array}{l}\text { By comparison with } \\
\text { Lemperaturt recorded } \\
\text { on th-100 }\end{array}$ & $\begin{array}{l}\text { lalue high indt- } \\
\text { cation of botlet } \\
\text { outlet tempera- } \\
\text { cure }\end{array}$ & As 1.40 & & 2 & 1 & \\
\hline & 1.45 & $\begin{array}{l}\text { Falls lndicating } \\
\text { false low tempera } \\
\text { ture }\end{array}$ & & As 1.44 & $\begin{array}{l}\text { Valse low indl- } \\
\text { catton of bollen } \\
\text { ontlet tempera- } \\
\text { ture }\end{array}$ & As 1.40 & & 2 & 1. & \\
\hline \multirow[t]{2}{*}{$\begin{array}{l}\text { lenperature } \\
\text { Recurder }\end{array}$} & 1.46 & $\begin{array}{l}\text { Palls recordlag } \\
\text { false high tein- } \\
\text { perature }\end{array}$ & & As 1.14 & As 1.44 & & & 2 & $\mathrm{~J}$ & \\
\hline & 1.47 & $\begin{array}{l}\text { laalls recordl.ng } \\
\text { false low ten- } \\
\text { perature }\end{array}$ & & As 1.44 & As 1.45 & & & 2 & .1 & \\
\hline $\begin{array}{l}\text { lalve down- } \\
\text { stream of } \\
\text { putip } p^{2}-1.01\end{array}$ & 1.50 & Valve closu:d & Error & & $\begin{array}{l}\text { Deadliead lng of } \\
\text { pump }\end{array}$ & ito flow & No flow shutatown & 1. & 3 & \\
\hline $\begin{array}{l}\text { Jall ve up- } \\
\text { streant of } \\
\text { pump p-10s }\end{array}$ & $1 . .51$ & Vallue clased & Lirror & & $\begin{array}{l}\text { Cavtcacton ln } \\
\text { pump }\end{array}$ & No flow & No flow shutdowi & 1. & 3 & \\
\hline Line & 1.60 & f.lue leaks & $\begin{array}{l}\text { Fat lurc/leak at } \\
\text { comnections, } \\
\text { fnpact }\end{array}$ & $\begin{array}{l}\text { Possible flow reduc- } \\
\text { tion, fall. lin level } \\
\text { of cank Th-10I. } \\
\text { spill. ob:served }\end{array}$ & $\begin{array}{l}\text { Splll hear ctans } \\
\text { fer fluid }\end{array}$ & $\begin{array}{l}\text { liall in } \\
\text { level of } \\
\text { fluld in } \\
\text { systell. } \\
\text { fire }\end{array}$ & 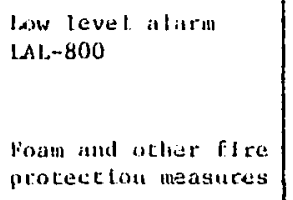 & 2 & $2-5$ & 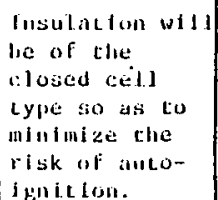 \\
\hline \multirow[t]{2}{*}{$\begin{array}{l}\text { colloctor } \\
\text { Sc-101/11.5 }\end{array}$} & 2.10 & Rupture & Ivapact & & $\begin{array}{l}\text { bonabe to collues } \\
\text { ror }\end{array}$ & $\begin{array}{l}\text { liscalpe of } \\
\text { fluid }\end{array}$ & 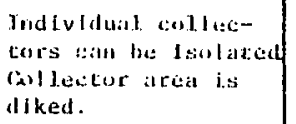 & 2 & 5 & $\begin{array}{l}\text { Val ves will be } \\
\text { placed on the } \\
\text { bartoun of pipes } \\
\text { so cliat leaks }\end{array}$ \\
\hline & 2.11 & $\begin{array}{l}\text { lixcessive cenm } \\
\text { meracure th col- } \\
\text { lerenr }\end{array}$ & $\begin{array}{l}\text { desw/no flow } \\
\text { rlirough colt- } \\
\text { tection }\end{array}$ & & $\begin{array}{l}\text { Possible over- } \\
\text { pressure bu tube } \\
\text { coking/degrada- } \\
\text { mon of fludal }\end{array}$ & 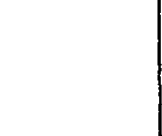 & 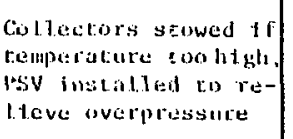 & 2 & 5 & $\begin{array}{l}\text { will not dratn } \\
\text { into the lusu- } \\
\text { Lation. }\end{array}$ \\
\hline $\begin{array}{l}\text { Colleccour } \\
\text { st--101/11.5 }\end{array}$ & 2.1 .2 & l.eaks & $\begin{array}{l}\text { Defects in minn } \\
\text { ifacture and } \\
\text { installation }\end{array}$ & Visinal & Loss of flluld & $\begin{array}{l}\text { Prasitible } \\
\text { flete }\end{array}$ & & 3 & 3 & \\
\hline
\end{tabular}


level Nu. I Heat-Trans fer fluid

Level. No. 2 Instrumentarton

Program: Solar f'roducton of Industrial Process stcom

l.evel No. '3

Drawlug: 60863-50-

l.evel No. 4

\begin{tabular}{|c|c|c|c|c|c|c|c|c|c|c|}
\hline \multirow{2}{*}{$\begin{array}{l}\text { linectonat } \\
\text { lesictipetion }\end{array}$} & \multicolumn{2}{|c|}{ Fatlure Mode } & \multirow{2}{*}{$\begin{array}{l}\text { Posslble } \\
\text { Causes }\end{array}$} & \multirow{2}{*}{$\begin{array}{l}\text { Symptoms } \\
\text { Detectability }\end{array}$} & \multicolumn{2}{|c|}{ Effect of Fallure } & \multirow{2}{*}{$\begin{array}{l}\text { Existing } \\
\text { Compensating } \\
\text { Proviston }\end{array}$} & \multirow{2}{*}{$\begin{array}{l}\text { Prolba- } \\
\text { bilitey }\end{array}$} & \multirow{2}{*}{$\begin{array}{l}\text { Level. of } \\
\text { Severity }\end{array}$} & \multirow{2}{*}{ Remarks } \\
\hline & SN & Deserfption & & & locat EFfect & End tefect & & & & \\
\hline - & 1.31 & $\begin{array}{l}\text { falls indicalang } \\
\text { false low templiat } \\
\text { tare }\end{array}$ & & $\Lambda_{3} 1.30$ & $\begin{array}{l}\text { False low col- } \\
\text { lector dulet } \\
\text { Lemperatine re- } \\
\text { corded }\end{array}$ & 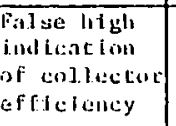 & & 2 & 1 & \\
\hline $\begin{array}{l}\text { Recorder } \\
\text { tr-10n }\end{array}$ & 1.32 & $\begin{array}{l}\text { Palls recording } \\
\text { false higlt tem- } \\
\text { peratere }\end{array}$ & & As 1.30 & As 1.30 & & $\begin{array}{l}\text { Temperature recurded } \\
\text { on } \tau^{1} \mathrm{i}-401 .\end{array}$ & 2 & 1 & - \\
\hline \multirow[t]{2}{*}{ Fill $T ?-101$} & $1 . .34$ & $\begin{array}{l}\text { Eatls findicating } \\
\text { false high } \\
\text { cemperature }\end{array}$ & & 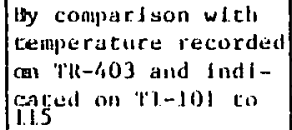 & $\begin{array}{l}\text { lialse lidgh col- } \\
\text { lector nutlet } \\
\text { lenperature ce- } \\
\text { corded }\end{array}$ & 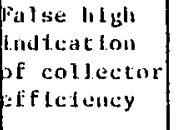 & & 2 & 1. & \\
\hline & 1.35 & $\begin{array}{l}\text { lails fnd leating } \\
\text { false low tem- } \\
\text { purative }\end{array}$ & & As 1.34 & $\begin{array}{l}\text { False low col- } \\
\text { bector outlec } \\
\text { lemperature re- } \\
\text { corded }\end{array}$ & $\begin{array}{l}\text { alse low lin } \\
\text { ilcation of: } \\
\text { :ollector } \\
\text { fiflicincy }\end{array}$ & & 2 & L & \\
\hline $\begin{array}{l}\text { Temperacure } \\
\text { kecorder TR- } \\
\text { l01 }\end{array}$ & 1.37 & $\begin{array}{l}\text { Pallis recurcing } \\
\text { false low tem- } \\
\text { peratcure }\end{array}$ & & A.s 1.34 & As 1.35 & & & 2 & 1 & \\
\hline \multirow[t]{2}{*}{ KTI) $2 T-403$} & 1.40 & $\begin{array}{l}\text { Falls lindfeating } \\
\text { false high ocell- }\end{array}$ & & 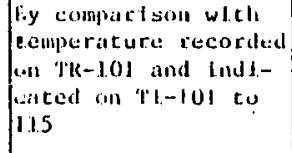 & $\begin{array}{l}\text { False high lindf- } \\
\text { cation of botler } \\
\text { fnlec temperacure }\end{array}$ & $\begin{array}{l}\text { lat se findt- } \\
\text { catelon of } \\
\text { lieat trans- } \\
\text { fere in } \\
\text { bolles }\end{array}$ & & 2 & 1. & \\
\hline & 1.4 .1 & $\begin{array}{l}\text { lands fudlcating } \\
\text { fallse low teent }\end{array}$ & & Ass 1.40 & 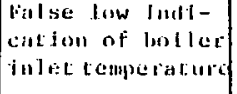 & $A: 21.41)$ & & 2 & 1 & \\
\hline \multirow[t]{2}{*}{$\begin{array}{l}\text { Tempieraticure } \\
\text { lietorditr }\end{array}$} & 1.42 & $\begin{array}{l}\text { Records false habl } \\
\text { Lemperatures }\end{array}$ & & An: 1.40 & As $1.1,0$ & & & 2 & 1 & \\
\hline & 1.43 & $\begin{array}{l}\text { Recoursts fulse low } \\
\text { remperature }\end{array}$ & & $\Delta=1.40$ & $A=1.41$. & & & 2 & 1. & \\
\hline
\end{tabular}


level No. 1 Heat-Transfer Muid Ctrculatem

level No. 2 cullector

Program: Solat Production of Industriat. Process stean

L.uel No. 3

Dribling: $60863-50-1$.

\begin{tabular}{|c|c|c|c|c|c|c|c|c|c|c|}
\hline \multirow{2}{*}{$\begin{array}{l}\text { Funcetonat } \\
\text { Descrtpeton }\end{array}$} & \multicolumn{2}{|c|}{ Fatlure Mode } & \multirow{2}{*}{$\begin{array}{l}\text { Pussible } \\
\text { Causes }\end{array}$} & \multirow{2}{*}{$\begin{array}{l}\text { Symptoass } \\
\text { Detectabliticy }\end{array}$} & \multicolumn{2}{|c|}{ liffect of fallure } & \multirow{2}{*}{$\begin{array}{l}\text { Exiscl.ng } \\
\text { Compensating } \\
\text { provission }\end{array}$} & \multirow{2}{*}{$\begin{array}{l}\text { Proba- } \\
\text { bllicy }\end{array}$} & \multirow{2}{*}{$\begin{array}{l}\text { Level of } \\
\text { Severiliy }\end{array}$} & \multirow{2}{*}{ Renarks } \\
\hline & SN & Description & & & Loeill Eftect & End leffect & & & & \\
\hline \multirow{5}{*}{ Collector } & 2.13 & $\begin{array}{l}\text { Eutry of cool } \\
\text { 1.1 qual d linto thot } \\
\text { cube }\end{array}$ & $\begin{array}{l}\text { Milsinap, late } \\
\text { opending of } \\
\text { isolaclout } \\
\text { valves }\end{array}$ & & Thermat shock & $\begin{array}{l}\text { Leaks de- } \\
\text { velop }\end{array}$ & . & 2 & 3 & 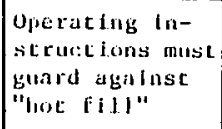 \\
\hline & 2.14 & $\begin{array}{l}\text { Percolation of } \\
\text { filuld futo empey } \\
\text { tube }\end{array}$ & Valdves leak & & $\begin{array}{l}\text { Therisal stresses } \\
\text { exposure of work } \\
\text { ers tol flutal }\end{array}$ & & & 2 & 5 & \\
\hline & 2.15 & 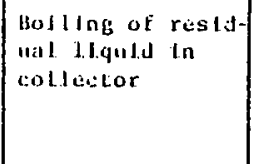 & 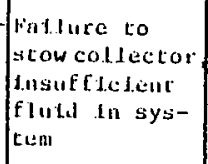 & & Thermal stresse: & & & 2 & 3 & . \\
\hline & 2.16 & Stiress & II i.gh wllud & $\begin{array}{l}\text { Visual, wind speed } \\
\text { indlcator }\end{array}$ & $\begin{array}{l}\text { Foundiat fun } \\
\text { danadige }\end{array}$ & & $\begin{array}{l}\text { Collec cors stow in } \\
\text { higls wind }\end{array}$ & 3 & 3 & \\
\hline & 2.1 .7 & $\begin{array}{l}\text { Damagi to collee } \\
\text { tor surfaces }\end{array}$ & Hia:ll. & Visiast 1. & $\begin{array}{l}\text { Damage co col- } \\
\text { lector surfaces }\end{array}$ & & $\begin{array}{l}\text { Collectors stow when } \\
\text { insolation low }\end{array}$ & 2 & 3 & \\
\hline \multirow[t]{3}{*}{$\begin{array}{l}\text { Valves chat } \\
\text { lsolate col- } \\
\text { lector }\end{array}$} & 2.20 & $\begin{array}{l}\text { Closure of one } \\
\text { value }\end{array}$ & $\begin{array}{l}\text { Accidential } \\
\text { closting of } \\
\text { wrong vallve }\end{array}$ & & $\begin{array}{l}\text { Excesslve cem- } \\
\text { perature in } \\
\text { collecteror }\end{array}$ & $\begin{array}{l}\text { Degradation } \\
\text { of flud }\end{array}$ & Stuwage of collector & 2 & 2 & \\
\hline & 2.21 & $\begin{array}{l}\text { Closure of both } \\
\text { lsolat lon valves } \\
\text { about collector }\end{array}$ & As 2.20 & & As 2.20 & $\begin{array}{l}\text { overpres- } \\
\text { sure in } \\
\text { collector }\end{array}$ & $\begin{array}{l}\text { Stowage of collecterr } \\
\text { p'sv }\end{array}$ & 2 & 5 & \\
\hline & 2.22 & $\begin{array}{l}\text { opeulng of sup- } \\
\text { possedly closed } \\
\text { vallevel leaks }\end{array}$ & 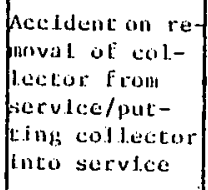 & & $\begin{array}{l}\text { Posidb le expo- } \\
\text { sure of person- } \\
\text { nel to hoe heat: } \\
\text { transfer fluld }\end{array}$ & & $\begin{array}{l}\text { 1.ines will be blanked } \\
\text { iffe }\end{array}$ & 2 & 5 & \\
\hline $\begin{array}{l}\text { Collecior } \\
\text { bratu palve }\end{array}$ & 2.23 & $\begin{array}{l}\text { Actildentahlly } \\
\text { opened/fatls copen }\end{array}$ & Arror & $\begin{array}{l}\text { Vlsual, low level. } \\
\text { :Lactu l.Al-80a }\end{array}$ & sptitl of thequal & $\begin{array}{l}\text { Possible } \\
\text { fire }\end{array}$ & $\cdot$ & 2 & 5 & \\
\hline$P S V-10 \pm / 11.5$ & 2.24 & strcks & & & $\begin{array}{l}\text { Thube ruplutec on } \\
\text { overpressillice }\end{array}$ & & $\begin{array}{l}\text { Collector stowed } 1 f \\
\text { remperature fin col. } \\
\text { lectoe lif bil }\end{array}$ & 2 & s & \\
\hline & $\because 25$ & $\begin{array}{l}\text { Discharge whe } \\
\text { blocked }\end{array}$ & |sebrisi/ice & & A:: 2.24 & & hs 2.24 & 2 & 5 & \\
\hline & 2.26 & $\begin{array}{l}\text { Premacure operat } \\
\text { ctom }\end{array}$ & & Vilsual. & As 2.23 & As 2.23 & & 2 & j & \\
\hline
\end{tabular}


Level No. I Meat-Transfer lilutd Clrculation, Butler

Leviel No. 2 collector

Progran: Sulat l'roduction of Ludustrial process Steam

Level Nu. 3

Petses-50-1

Level Nu.

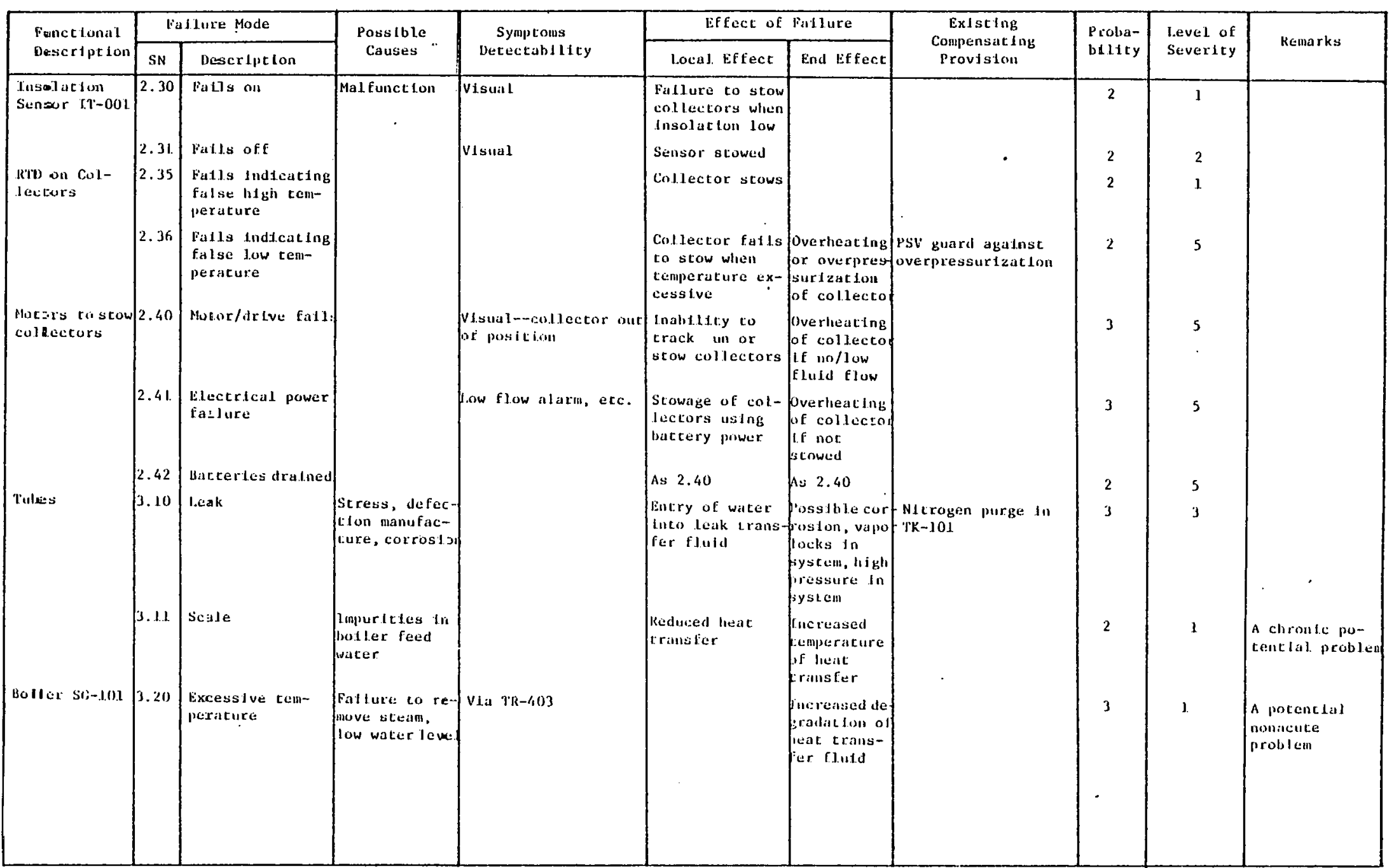


Level No. I Hear-Transfer fluid circulation, Builier

Level No. 2

Prugran: Solar Production of Endustrtal. Process Steatn

level No. 3

Level. No, 4

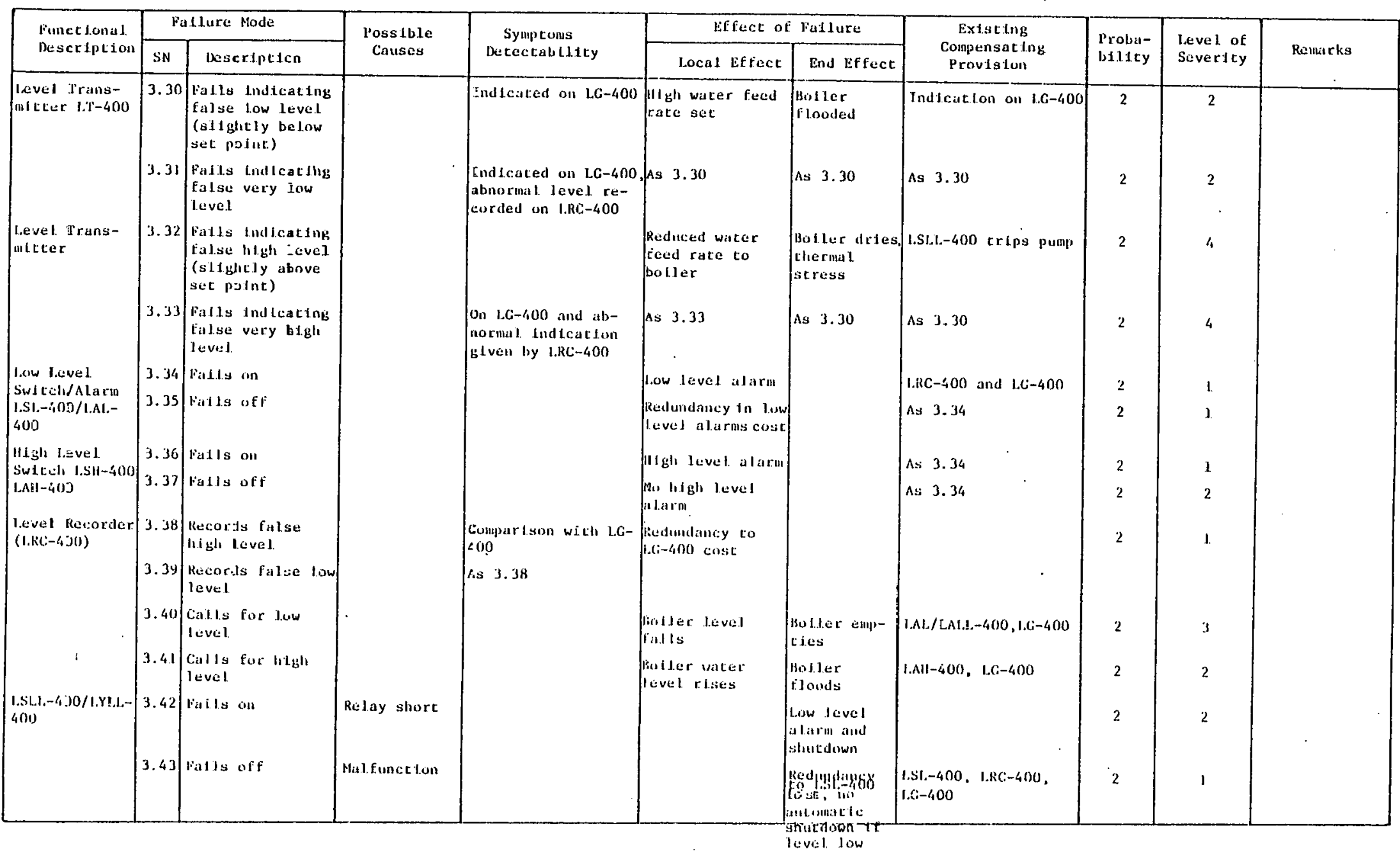


L.evel No. 4

\begin{tabular}{|c|c|c|c|c|c|c|c|c|c|c|}
\hline \multirow{2}{*}{$\begin{array}{l}\text { Functional } \\
\text { Description }\end{array}$} & \multicolumn{2}{|c|}{ Fatlure Mode } & \multirow{2}{*}{$\begin{array}{l}\text { Posalble } \\
\text { Caluses }\end{array}$} & \multirow{2}{*}{$\begin{array}{c}\text { Symptouns } \\
\text { Betectabllity }\end{array}$} & \multicolumn{2}{|c|}{ Ef fect of Fatlure } & \multirow{2}{*}{$\begin{array}{l}\text { Existing } \\
\text { Compensating } \\
\text { Proviston } \\
\end{array}$} & \multirow{2}{*}{$\begin{array}{l}\text { l'ruba- } \\
\text { bidifty }\end{array}$} & \multirow{2}{*}{$\begin{array}{l}\text { Level of } \\
\text { Severity }\end{array}$} & \multirow{2}{*}{ Renarks } \\
\hline & SN & Description & & & Local Effect & End effect & & & & \\
\hline \multirow[t]{2}{*}{ 1.ALLL-400 } & 3.44 & Patlis on & & & Low level alarin & - & & 2 & 1 & \\
\hline & 3.45 & Fatis off & & & $\begin{array}{l}\text { Second alarn on } \\
\text { low level not } \\
\text { glven }\end{array}$ & & $\begin{array}{l}L A L-400, \text { I.RC- } 400 \\
\pm G-400\end{array}$ & 2 & 1 & \\
\hline \multirow{4}{*}{$\begin{array}{l}\text { Botler Feed- } \\
\text { water flow } \\
\text { Controller } \\
\text { WhC }-400\end{array}$} & 3.50 & $\begin{array}{l}\text { ladls callung for } \\
\text { low flow }\end{array}$ & ${ }^{\circ}$ & & As 3.40 & As 3.40 & $A=3.40$ & 2 & 3 & \\
\hline & 3.51 & $\begin{array}{l}\text { Fallis calling for } \\
\text { lit ghe flow }\end{array}$ & & & As 3.41 & As 3.41 & As 3.41 & 2 & 2 & \\
\hline & 3.53 & $\begin{array}{l}\text { Recrirds false low } \\
\text { fluo }\end{array}$ & & & $\begin{array}{l}\text { Measurements } \\
\text { lost }\end{array}$ & & WQI. 40 & 2 & 1. & \\
\hline & 3.54 & $\begin{array}{l}\text { Recurds false } \\
\text { high flow }\end{array}$ & · & & As 3.53 & & As 1.53 & 2 & 1 & \\
\hline \multirow[t]{2}{*}{$\begin{array}{l}\text { Fluv Trans- } \\
\text { interer WL }-400 \text {, } \\
\text { WY }-400\end{array}$} & 3.55 & $\begin{array}{l}\text { Find-s Indicating } \\
\text { false high flow }\end{array}$ & .. & $\begin{array}{l}\text { Abnormal flow rate } \\
\text { Lndicated }\end{array}$ & $\begin{array}{l}\text { How reduced in- } \\
\text { t1l level too } \\
\text { low }\end{array}$ & & $\begin{array}{l}\text { Flow control set } \\
\text { potot determined by } \\
\text { boller level }\end{array}$ & 2 & 2 & \\
\hline & 3.56 & $\begin{array}{l}\text { Fatics indicating } \\
\text { falac low flow }\end{array}$ & & As 3.55 & $\begin{array}{l}\text { lilow lincreased } \\
\text { mint li level ex- } \\
\text { cessive }\end{array}$ & & & 2 & 1 & \\
\hline \multirow[t]{2}{*}{ 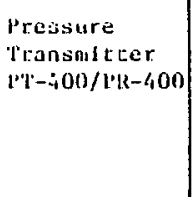 } & 3.57 & $\begin{array}{l}\text { Falis find teating } \\
\text { false hilgh pres- } \\
\text { sure }\end{array}$ & & $\begin{array}{l}\text { Pressure not in ac- } \\
\text { cord with reconded } \\
\text { temperiture }\end{array}$ & & & - & 2 & 1. & \\
\hline & 3.58 & $\begin{array}{l}\text { Palls lndlcating } \\
\text { falae low pres- } \\
\text { sute }\end{array}$ & & As 3.57 & $\begin{array}{l}\text { Indication of } \\
\text { pressiure lost }\end{array}$ & & $\operatorname{Psv}-400$ & 2 & 1 & \\
\hline \multirow[t]{2}{*}{$W V-100$} & 3.60 & $\begin{array}{l}\text { liallis clused/ } \\
\text { fails to open }\end{array}$ & Halfunction & & $\begin{array}{l}\text { Insufficleut liow } \\
\text { bndler feedwater }\end{array}$ & $\left|\begin{array}{ll}\text { Level. In } \\
\text { butller feeds }\end{array}\right|$ & Bypass & 2 & 3 & \\
\hline & 3.61 & $\begin{array}{l}\text { Falls open/sticks } \\
\text { closed }\end{array}$ & $\begin{array}{l}\text { Loss instru- } \\
\text { ment air }\end{array}$ & & $\begin{array}{l}\text { Excesslve flow } \\
\text { bouller feedwater }\end{array}$ & $\begin{array}{l}\text { luvel in } \\
\text { bodler ises }\end{array}$ & & 2 & 2 & \\
\hline $\begin{array}{l}\text { Bypess to } \\
W V-; 00\end{array}$ & 3.62 & Opered & Error & & $\begin{array}{l}\text { Control over } \\
\text { boiller feedivater }\end{array}$ & $\mid \begin{array}{l}\text { I.uvel fin } \\
\text { bull Ier rises }\end{array}$ & & 2 & 2 & \\
\hline $\begin{array}{l}\text { Safiecy Val.ve } \\
\text { l? SV-400 }\end{array}$ & 3.70 & Falles to open & & & $\begin{array}{l}\text { Pabllate to re- } \\
\text { shove overpres- } \\
\text { surte }\end{array}$ & $\begin{array}{l}\text { Rupicure } \\
\text { boller }\end{array}$ & & 2 & 5 & \\
\hline
\end{tabular}


Level No. 1 Boiler, Heat-'tramsfer Elutd Circulation

level No. 2 Dural Tark

Progran: Solar Prodmecion of Industrial Process Steam

Level No. 3

Level No. 4

Drawlug: 60863-50-1

\begin{tabular}{|c|c|c|c|c|c|c|c|c|c|c|}
\hline \multirow{2}{*}{$\begin{array}{l}\text { Functlonal } \\
\text { buescrtption }\end{array}$} & \multicolumn{2}{|c|}{ Patlure Mode } & \multirow{2}{*}{$\begin{array}{l}\text { Possible } \\
\text { Causes }\end{array}$} & \multirow{2}{*}{$\begin{array}{l}\text { Symptoms } \\
\text { Detectab l.1.1ty }\end{array}$} & \multicolumn{2}{|c|}{ Effece of tallure } & \multirow{2}{*}{$\begin{array}{l}\text { Exlsting } \\
\text { Conpensating } \\
\text { Provision }\end{array}$} & \multirow{2}{*}{$\begin{array}{l}\text { Proba- } \\
\text { bility }\end{array}$} & \multirow{2}{*}{$\begin{array}{l}\text { Level of } \\
\text { Severtity }\end{array}$} & \multirow{2}{*}{ Remarks } \\
\hline & SN & Description & & & 1oncal Effect & End Effect & & & & \\
\hline & 3.71 & Upens prematurely & & & $\begin{array}{l}\text { I.oss of steanu } \\
\text { pressure }\end{array}$ & & & 2 & 2 & \\
\hline $\begin{array}{l}\text { Valves an } \\
\text { stean lifine }\end{array}$ & 3.80 & Closed & Error & & $\begin{array}{l}\text { Holler water le- } \\
\text { vel and lethipera- } \\
\text { lure rlses }\end{array}$ & $\begin{array}{l}\text { Pressure } \\
\text { rlses }\end{array}$ & $P S V-400$ & 2 & 4 & \\
\hline \multirow[t]{2}{*}{$\begin{array}{l}\text { Pressure Regu- } \\
\text { lat } 1 \text { ng Vallve } \\
\text { PCV }-400\end{array}$} & 3.81 & $\begin{array}{l}\text { Patl.s gliviug } \\
\text { high pressure }\end{array}$ & $\begin{array}{l}\text { itssec/inal- } \\
\text { function }\end{array}$ & Nia Tl-800 & & $\begin{array}{l}\text { Tenperatiure } \\
\text { in dunp tank } \\
\text { lilgher than } \\
\text { antjelpated }\end{array}$ & & 2 & 1. & \\
\hline & 3.82 & $\begin{array}{l}\text { Falle giving low } \\
\text { pressure }\end{array}$ & $\begin{array}{l}\text { Milsset/mal- } \\
\text { functlon }\end{array}$ & Via $11-800$ & & $\begin{array}{l}\text { Temperature } \\
\text { tn dump tank } \\
\text { lower than } \\
\text { untet.pated }\end{array}$ & & & & \\
\hline \multirow[t]{2}{*}{$\begin{array}{l}\text { Wholler leed- } \\
\text { Wäter }\end{array}$} & 3.83 & Low pressure & $\begin{array}{l}\text { Fallure pump, } \\
\text { l.eaks }\end{array}$ & & $\begin{array}{l}\text { Low flow co } \\
\text { bollter }\end{array}$ & $\begin{array}{l}\text { level in } \\
\text { boller fafls }\end{array}$ & & 2 & 3 & \\
\hline & 3.84 & Infindites & & & l'ronote scalling & & & 2 & 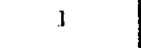 & \\
\hline \multirow[t]{2}{*}{ Dusup l'ank } & 4.10 & Hoptured & $\begin{array}{l}\text { lmpact, tatl } \\
\text { ure, corro- } \\
\text { ston }\end{array}$ & VIsual. & spsll.1 of flutd & $\begin{array}{l}\text { Possible } \\
\text { flre }\end{array}$ & Area diked & 2 & 5 & \\
\hline & 4.1 .1 & Draln left open & Error & & $\left\{\begin{array}{l}\text { loss of fluld to } \\
\text { porcesss sewer }\end{array}\right.$ & $\begin{array}{l}\text { Yosstible } \\
\text { fire In } \\
\text { sewer, low } \\
\text { level of } \\
\text { Elinld in } \\
\text { system, low } \\
\text { flow of } \\
\text { fituld }\end{array}$ & $\begin{array}{l}\text { Low level. alarm for } \\
\text { tank }\end{array}$ & 2 & 5 & \\
\hline Vapor space & & Contalins alt & $\begin{array}{l}\text { looking up ed } \\
\text { wrong l. lne } \\
\text { rvc-801 closed }\end{array}$ & & $\left|\begin{array}{l}\text { Hlandiable at- } \\
\text { mosplitere creatced }\end{array}\right|$ & 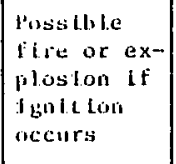 & 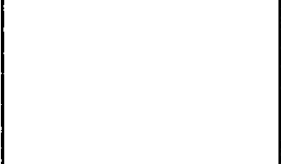 & 2 & 5 & \\
\hline level lange & 4.20 & $\begin{array}{l}\text { Falls land leat ling } \\
\text { talse lif bl level }\end{array}$ & & & $\mid \begin{array}{l}\text { Possible empty- } \\
\text { tug/insufficlent } \\
\text { pill ting of tank }\end{array}$ & $\begin{array}{l}\text { l.ciw Elutd } \\
\text { lin licved in } \\
\text { syscen }\end{array}$ & 1.A1--800 & 2 & 3 & $\begin{array}{l}\text { Ensure level } \\
\text { fauge is ade- } \\
\text { fuately pro- } \\
\text { ected agalnst } \\
\text { breatkilge }\end{array}$ \\
\hline
\end{tabular}


Level No. 1 Heat-Iranser Flutd

level No. 2 Mumip I' ari', N Itrogen Purge

progran: Solar production of Industrial Process Stean level No. 3

Level No. 4

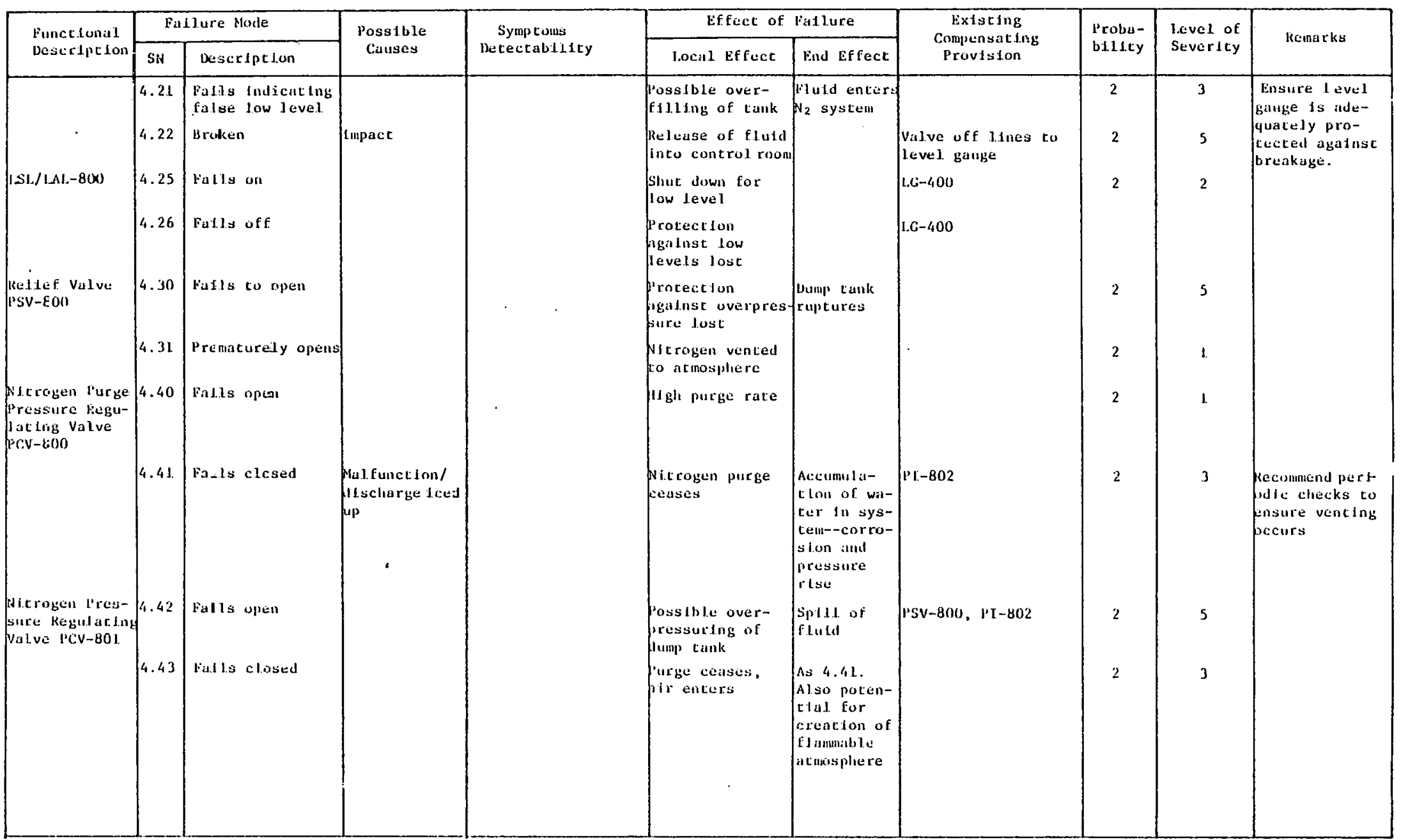


Level No, 1 Heat-Tramefer fluid Citculation

Level No. 2 Nlerogen Purge, Meat-Transfer fluld, Instruments

Progran: Solar Production of Industrial Process Stean

Level No. 3

l.evel No. 4

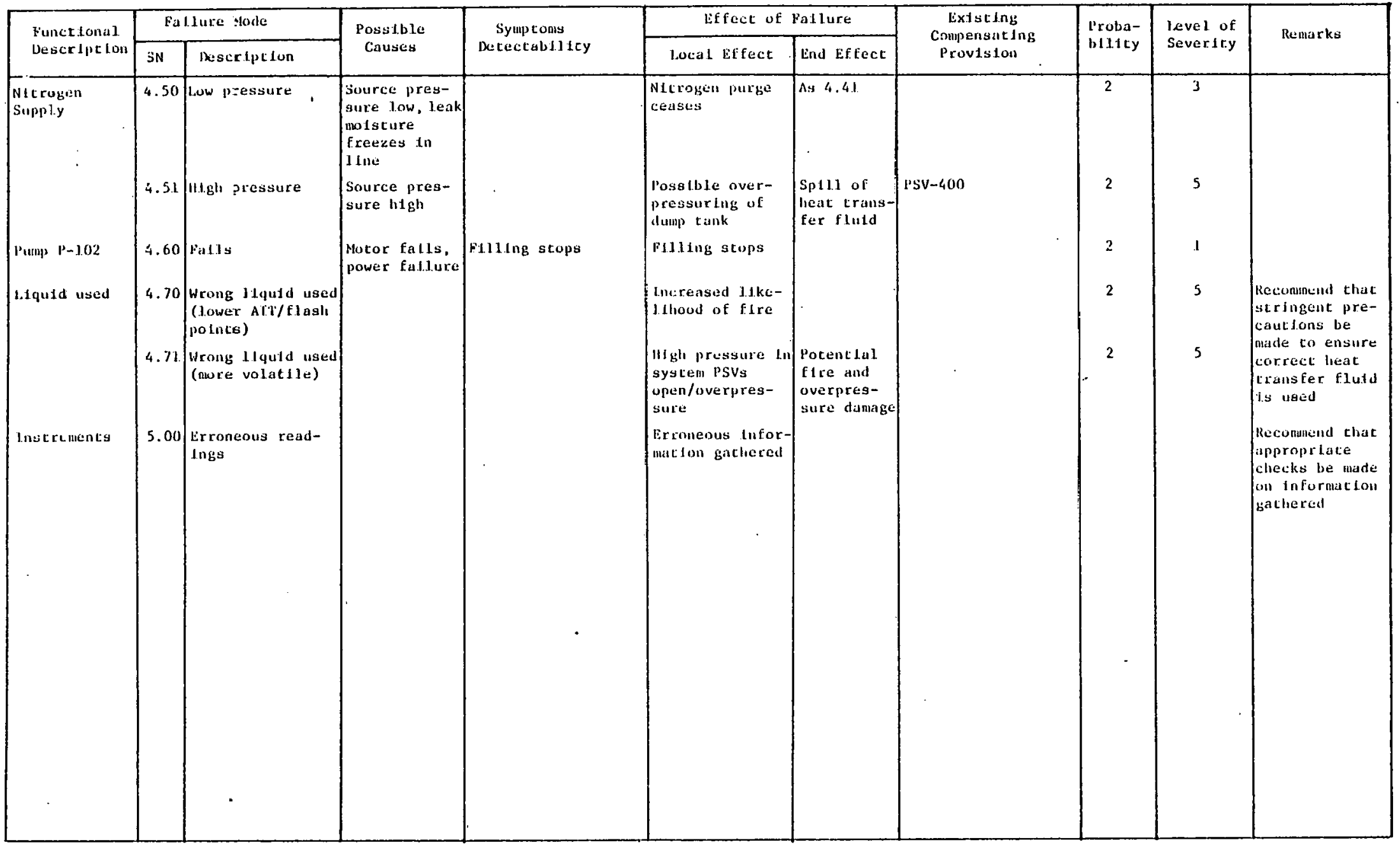

